SZEGEDI TUDOMÁNYEGYETEM

TERMÉSZETTUDOMÁNYI ÉS INFORMATIKAI KAR

FIZIKA DOKTORI ISKOLA

\title{
II-es típusú szupernóvák távolságának meghatározása
}

\author{
Doktori értekezés \\ Takáts Katalin \\ TÉMAVEZETő: \\ Dr. Vinkó József \\ SZTE Optikai és Kvantumelektronikai Tanszék
}




\section{Tartalomjegyzék}

$\begin{array}{ll}\text { Bevezetés } & 3\end{array}$

1. Szupernóvák 5

1.1. Csoportosításuk . . . . . . . . . . . . . . . . . 7

1.1.1. Az egyes típusok előfordulásának gyakorisága . . . . . . . . . . 99

1.2. A szupernóvák fénygörbéje . . . . . . . . . . . . . . . . . . . . . . . . . . . . . 10

1.3. Az Ia típusú szupernóvák . . . . . . . . . . . . . . . . . . . . . . . 13

1.4. A nagy tömegú csillagok összeomlásával keletkező szupernóvák . . . . . . . 13

1.4.1. A nagy tömegú csillagok fejlődése és halála . . . . . . . . . . . . . 14

1.4.2. Az Ib/c típusú szupernóvák . . . . . . . . . . . . . . . . . . . . 15

1.4.3. II-es típusú szupernóvák . . . . . . . . . . . . . . . . 16

2. Távolságmérés szupernóvákkal 20

2.1. Az Ia típusú $\mathrm{SN}-\mathrm{k}$ távolsága . . . . . . . . . . . . . . . . . . . . 20

2.2. A II-es típusú szupernóvák távolsága - a táguló fotoszféra módszer . . . . . . 22

2.2.1. A látszó szögméret meghatározása . . . . . . . . . . . . . . . 24

2.2.2. A tágulási sebesség mérése . . . . . . . . . . . . . . . . 26

2.2.3. Atmoszféramodellek és a korrekciós faktor . . . . . . . . . . . . 30

2.2.4. Fốbb nehézségek és hibaforrások . . . . . . . . . . . . . . 31

2.2.5. Az EPM variációi . . . . . . . . . . . . . . . . . . . 33

2.3. A II-es típusú SN-k távolsága - a standard(izált) gyertya módszer . . . . . . 33

3. Adatfeldolgozás 36

3.1. Nyers adatok feldolgozása . . . . . . . . . . . . . . . 36

3.1.1. Fotometria . . . . . . . . . . . . . . . 36

3.1.2. Spektroszkópia . . . . . . . . . . . . . . . . . 38

3.2. Sebességmérés a SYNOW nevú program használatával . . . . . . . . . . . . 39

3.2.1. A sYNOW alapjai . . . . . . . . . . . . . . . 39

3.2.2. Spektrumok modellezése a SYNOW-val . . . . . . . . . . . . 41

3.2.3. A fotoszferikus sebesség meghatározása . . . . . . . . . . . . . . 43

4. Eredmények 45

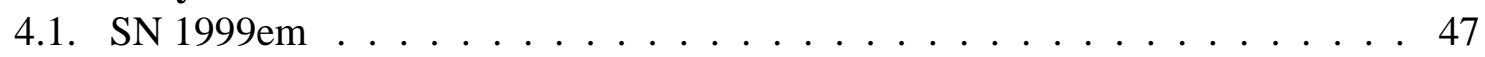

4.1.1. Spektrummodellezés és sebességmérés . . . . . . . . . . . . . . 47

4.1.2. Távolság . . . . . . . . . . . . . . . . . . . 49

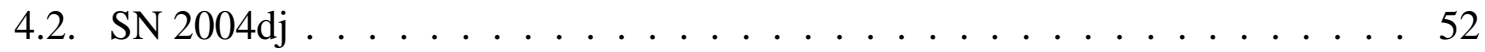


4.2.1. Spektrummodellezés és sebességmérés . . . . . . . . . . . 52

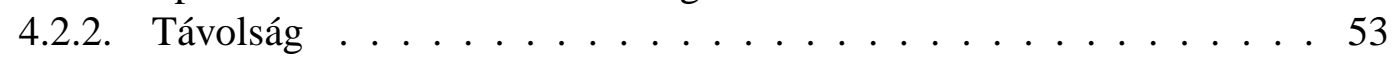

4.3. SN 2004et . . . . . . . . . . . . . . . . . . . . . . 5 53

4.3.1. Spektrummodellezés és sebességmérés . . . . . . . . . . . 56

4.3.2. Távolság . . . . . . . . . . . . . . . . . . . . . . . . . . . . . 57

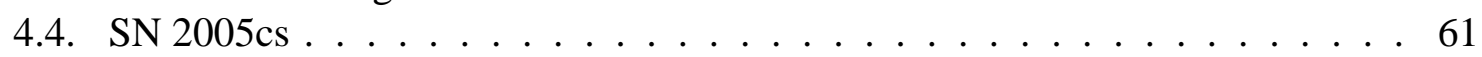

4.4.1. Spektrummodellezés és sebességmérés . . . . . . . . . . . . . 6 61 63

4.4.2. Távolság . . . . . . . . . . . . . . . 6 63

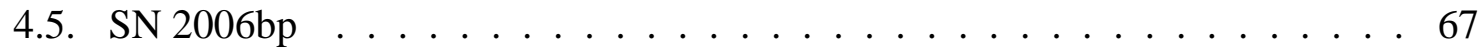

4.5.1. Spektrummodellezés és sebességmérés . . . . . . . . . . . . . 68

4.5.2. Távolság . . . . . . . . . . . . . . . . . . . 69

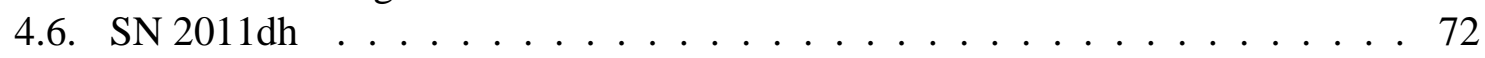

4.6.1. Spektrummodellezés és sebességmérés . . . . . . . . . . . . 73

4.6.2. Távolság . . . . . . . . . . . . . . . . . 73

5. Következtetések $\quad 76$

5.1. Sebesség-sebesség relációk . . . . . . . . . . . . . . . . . 80

5.2. A távolság és a távolságfüggó fizikai paraméterek . . . . . . . . . . . 83

Összefoglalás $\quad 89$

$\begin{array}{ll}\text { Summary } & 92\end{array}$

Köszönetnyilványítás $\quad 94$

Táblázatok jegyzéke $\quad 96$

$\begin{array}{ll}\text { Ábrák jegyzéke } & 99\end{array}$

$\begin{array}{ll}\text { Irodalomjegyzék } & 100\end{array}$

$\begin{array}{ll}\text { Mellékletek } & 107\end{array}$ 


\section{Bevezetés}

A szupernóvák kutatása napjainkban a csillagászat egyik legdinamikusabban fejlődő területe. A dedikált szupernóva-kereső programoknak köszönhetôen évről évre egyre több felfedezés történik, és az új objektumok némelyike egészen meglepő tulajdonságokat mutat, nem sorolható be a klasszikus kategóriákba. Ugyanakkor a leggyakrabban előforduló, régóta ismert típusok esetében is sok a megoldandó kérdés, mind a szülő́csillaguk természetét illetően, mind a robbanás során és utána végbemenő fizikai folyamatokat tekintve.

A szupernóváknak (szokásos rövidítéssel $\mathrm{SN}$ ) nagy szerepük van az extragalaktikus távolságmérésben. Erre a célra mind az Ia, mind a II-es típusú SN-k alkalmasak. Az Ia SN-kkel történő távolságmérésre irányuló törekvések már eddig is jelentôs eredményeket szolgáltattak, többek között segítségükkel mutatták ki, hogy az Univerzum gyorsulva tágul, mely felfedezésért szupernóva-kutatók (Brian Schmidt, Adam Riess és Saul Perlmutter) kapták a 2011-es fizikai Nobel-díjat. Ugyanakkor a használt eljárások empirikus kalibráción alapulnak, és - ahogy többek között Vinkó és mtsai (2012b) is megmutatták - az egyes módszerek még nem teljesen konzisztensek.

A II-es típusú, nagy tömegú csillagok összeomlásakor keletkező szupernóvák egy része is alkalmas távolságmeghatározásra. Két módszer is létezik erre a célra. Az egyik, a táguló fotoszféra módszer (expanding photosphere method, EPM; Kirshner \& Kwan, 1974), amelynek az alkalmazásához jó minőségú fénygörbe és a fotoszféra tágulási sebességének ismerete szükséges. A módszer nagy előnye, hogy nem igényel ismert távolságú objektumok felhasználásával végzett kalibrációt, így más módszerektől független eredményt szolgáltat. Hátránya, hogy jó időfelbontású és minőségú, a szupernóva korai fázisában felvett adatsort igényel. A másik, II-P típusú szupernóvák esetében alkalmazható eljárás a standard gyertya módszer (standard candle method, SCM; Hamuy \& Pinto, 2002), mely egy, a plató fázis közepén mérhető luminozitás és tágulási sebesség közti empririkus korrelációt használ fel. Az EPM-mel ellentétben ezt a módszert kalibrálni kell, viszont jóval kevesebb adatot igényel, ezáltal kevésbé jól észlelt objektumok esetében is alkalmazható.

Mindkét módszer esetében fontos probléma a fotoszféra tágulási sebességének megfelelően pontos meghatározása, melynek megoldására már több kísérlet is történt. Dolgozatomban egy olyan módszert ismertetek, amely során a SYNOW nevú, parametrizált, szupernóvák spektrumának modellezésére kifejlesztett program (Fisher, 1999) segítségével mérhetjük meg a tágulási sebességet. A módszer részletes vizsgálatához több szupernóva nagyszámú észlelt spektrumát használtam fel, majd a kapott sebességek segítségével a SN-k távolságát is meghatároztam.

Doktori dolgozatom elején egy rövid történeti áttekintést követően először ismertetem a szupernóvák csoportosításának szempontjait, valamint az egyes típusok felbukkanásának gyakoriságát. Ezt az egyes típusok keletkezésének és fóbb fizikai tulajdonságainak tárgyalása 
követi.

A második fejezetben azokról a módszerekról lesz szó, melyeket a szupernóvákkal történő távolságmérésben leggyakrabban alkalmaznak. Az Ia típusú szupernóvák esetében csak röviden ismertetem a használt eljárásokat, míg a II-P SN-k esetében részletesen ejtek szót mind a táguló fotoszféra-, mind a standard gyertya módszerről. Tárgyalom az egyes módszerek előnyeit, valamint az alkalmazásuk során felmerülő nehézségeket, fôbb hibaforrásokat is.

A harmadik fejezet arra az útra fókuszál, amit végig kell járnunk, amíg a nyers képektôl eljutunk a távolságmérési módszerekhez szükséges, kész adatokig. A fejezet második felében található annak a módszernek a leírása, mellyel a szupernóvák fotoszférájának tágulási sebességét határozom meg a SYNOW nevú modellezóprogram alkalmazásával (Takáts \& Vinkó, 2012).

A negyedik részben hat szupernóva (az SN 1999em, 2004dj, 2004et, 2005cs, 2006bp és 2011dh) nagyszámú spektrumának modellezésével kapott eredményeket ismertetem. A modellezés során kapott sebességeket összehasonlítom a más módszerekkel kapottakkal, valamint ezek felhasználásával a szupernóvák távolságának meghatározására is sor kerül.

Az ötödik fejezetben az eredmények és sebességmeghatározási módszerek összehasonlítása, valamint az ezekből levonható következtetések ismertetése szerepel. Végül ezt dolgozat fớbb eredményeinek összefoglalása követi. 


\section{1. fejezet}

\section{Szupernóvák}

Az égbolton váratlanul felbukkanó, majd néhány hét után újra eltűnő „,vendégcsillagokról" majdnem kétezer évre visszamenőleg találhatók írásos feljegyzések. A leírások segítségével a 20. század folyamán több esetben ezek maradványait is sikerült azonosítani (1.1. táblázat), melyek tanulmányozása, együtt a korabeli források által szolgáltott adatokkal jelentősen hozzájárul ezeknek az objektumoknak a megértéséhez.

A legrégebbi ismert észlelés i. sz. 185-ből származik, amikor kínai csillagászok figyeltek meg egy hirtelen felbukkanó, fényes csillagot. Pozíciójában, a Kentaur és a Körzô csillagképek közti területen található ma a G315.4-2.3 jelú szupernóva-maradvány (1.1. ábra). Hasonló jelenségról 369-ban, 386-ban és 393-ban is beszámoltak a kínaiak, ezek természetérôl viszont elég kevés ismerettel rendelkezünk, az sem bizonyított, hogy valóban szupernóvák voltak (Green \& Stephenson, 2003).

Az 1006-ban feltúnő fényes objektumról kínai, japán, európai és arab feljegyzések is vannak, egyes források szerint éveken keresztül látható volt. Valószínúleg az Ia típusba tartozott, maradványát, a PKS 1459-41 jelú rádióforrást 1965-ben azonosították.

Az SN 1054-ról több japán és kínai beszámoló is született, illetve egy arab forrás is megemlíti. Az 1920-as években vetették fel először a kínai feljegyzések alapján, hogy ennek maradványa lehet a Rák-köd, amit aztán alapos vizsgálatoknak vetettek alá. Mivel a Rák-köd azon kevés szupernóva-maradványok egyike, melynek központjában egy pulzár található, tanulmányozásának nagy jelentősége van a szupernóvák létrejöttének és fizikájának megismerésében.

Tycho Brahe fedezte fel az SN 1572-t, majd hónapokon keresztül pontos pozíció- és fényességméréseket végzett róla. A szupernóva maradványát 1952-ben azonosították. Krause és mtsai (2008b) a szupernóva fény-echójának spektrumát felvéve az Ia típusúba sorolták azt.

Az SN 1604 volt a legutóbbi szabad szemmel is látható szupernóva. Kínai és koreai csillagászok is hosszú időn keresztül követték, ám a legpontosabb fényességbecsléseket és koordinátákat Johannes Kepler megfigyeléseinek köszönhetjük. Ez utóbbiak alapján Baade volt az, aki késóbb megtalálta a maradványt.

A Tejútrendszerben a legfiatalabb ismert szupernóva-maradvány a Cassiopeia A jelet viseli. A rádiótól a gammáig a teljes hullámhossztartományon készültek és készülnek róla tanulmányok, melyek jelentősen hozzájárultak a szupernóvák fizikájának megértéséhez. A számítások szerint 1667 körül kellett a robbanásnak lezajlania, ám észleléséről nincsenek 


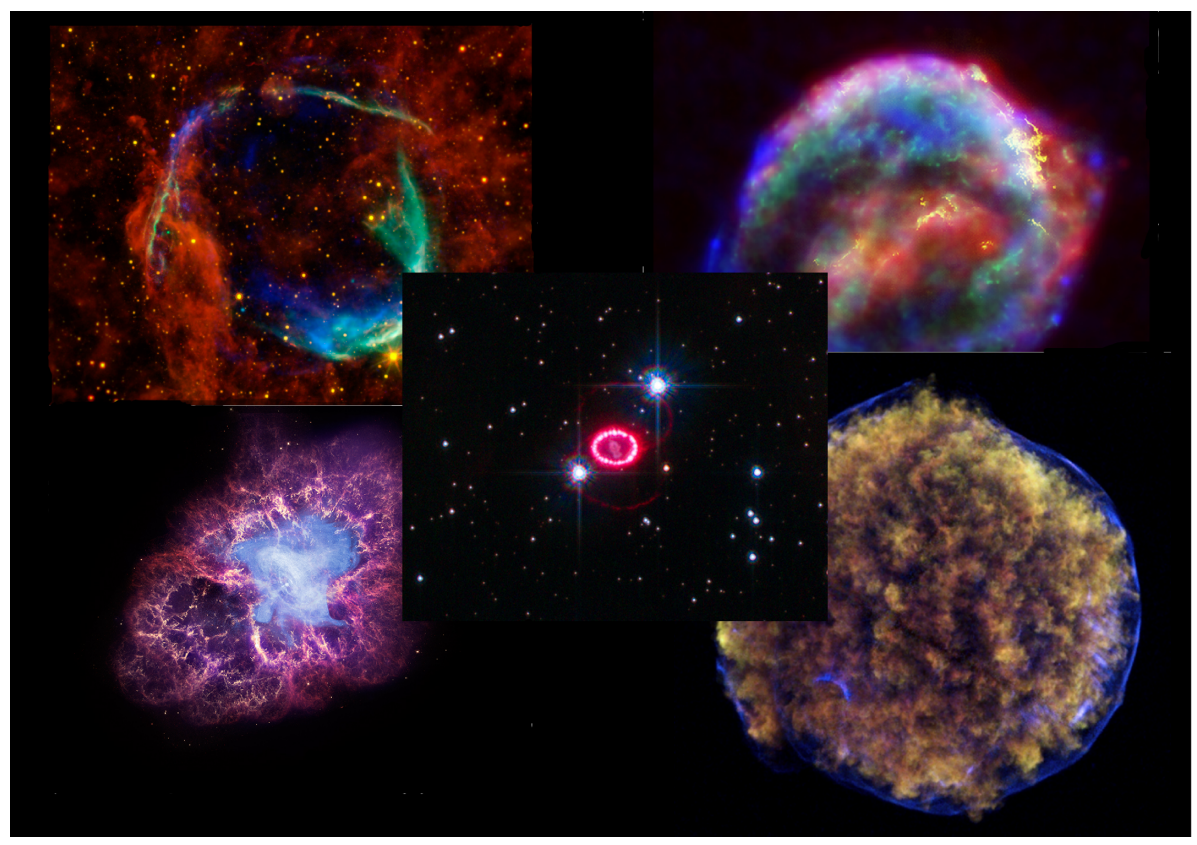

1.1. ábra. Különböző hullámhossztartományban készült képek az SN 185 (balra fent), SN 1054 (balra lent), SN 1064 (jobbra fent), SN 1572 (jobbra lent) és SN 1987A (középen) maradványáról. (Forrás: NASA/ESA)

feljegyzések. Ennek egy lehetséges oka a nagy mennyiségú csillagközi por lehetett, ami elnyelte az optikai sugárzás jelentős részét. Krause és mtsai (2008a) a fény-echó spektruma alapján IIb típusúnak sorolták be szupernóvát.

A távcső 17. századi elterjedésével egyre több, szabad szemmel nem látható vendégcsillagot fedeztek fel, többségét a Tejútrendszer sávjában. Ezekre az egymáshoz nagyon hasonló objektumokra mind a nóva elnevezést használták. Az 1885-ben feltűnő S Andromedae viszont az Androméda-köd magja közelében helyezkedett el. Ez az objektum is hasonló látszó fényességû volt, mint a többi nóva (kb. 6 magnitúdó) és fénygörbéje sem különbözött jelentősen azokétól. Azonban 1929-ben Edwin Hubble az Androméda-köd távolságát 2 millió fényévnek mérte, ami alapján az $\mathrm{S}$ And abszolút fényessége kb. -17

1.1. táblázat. Történelmi szupernóvák pozíciója, legvalószínúbb típusa és a maradványuk neve.

\begin{tabular}{ccccc}
\hline SN & Csillagkép & Pozíció & Maradvány & Típus \\
\hline 185 & Kentaur és Körzó & RA 14h 43m, Dec $-62^{\circ} 30^{\prime}$ & G315.4-2.3 & Ia \\
1006 & Farkas & RA 15h 2m, Dec $-41^{\circ} 57^{\prime}$ & PKS 1459-41 & Ia \\
1054 & Bika & RA 5h 34,5m, Dec $+22^{\circ} 01^{\prime}$ & Rák-köd & II \\
1572 & Cassiopeia & RA 0h 25,3m, Dec $+64^{\circ} 09^{\prime}$ & G120.1+2.1 & Ia \\
1604 & Kígyótartó & RA 17h 30m, Dec $-21^{\circ} 29^{\prime}$ & G4.5+6.8 & Ia \\
kb. 1667 & Cassiopeia & RA 23h 23m, Dec $+58^{\circ} 48^{\prime}$ & Cas A SNR & IIb \\
\hline
\end{tabular}




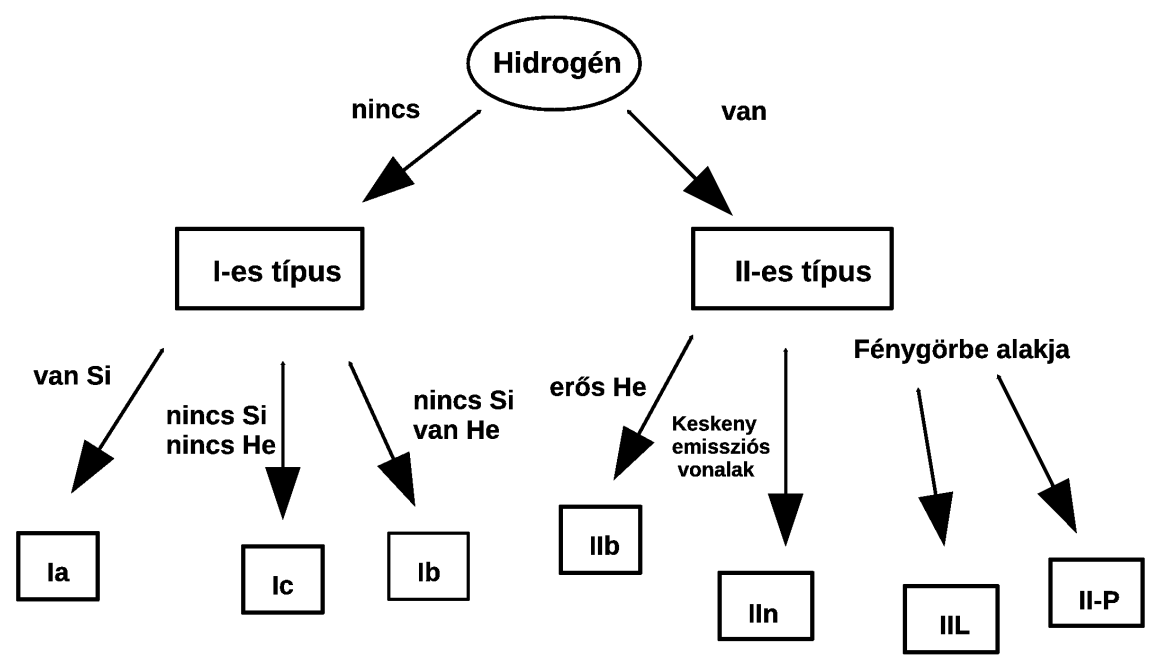

1.2. ábra. Szupernóvák alapvető csoportosítása a spektrumban található atomok/ionok és a fénygörbe alapján.

magnitúdó volt, ez pedig jóval nagyobb, mint akármelyik közönséges, a Tejútrendszerben található nóváé. Ez vezetett ahhoz a felismeréshez, hogy a Tejútrendszerben viszonylag gyakran felbukkanó nóvák és a más galaxisokban megjelenő, akár -18- -20 magnitúdó maximális fényességú objektumok egészen különbözőek. Az utóbbiakra a „szupernóva” elnevezést Baade \& Zwicky (1934) használta először.

A következő évtizedekben a szupernóvák keresése és tanulmányozása a csillagászat egyik nagyon fontos területévé vált. Egyre többet és többet fedeztek fel belőlük és egyre több ismeretre tettünk szert a természetükről. Nagy jelentőséggel bírt a Nagy Magellán-felhôben felbukkant SN 1987A, amelynek részletes, ma is folyó vizsgálata újabb lendületet adott a kutatásoknak.

Ebben a fejezetben ismertetem a szupernóvák legfőbb csoportjait, valamint nagy vonalakban az egyes típusokról jelenleg fennálló fizikai képet. Bár tudásunk ezekról az objektumokról gyorsan gyarapodik, még mind a mai napig sok a nyitott kérdés velük kapcsolatban.

\subsection{Csoportosításuk}

A szupernóvák csoportosítása hagyományosan azon alapul, hogy mely atomok és ionok vonalai figyelhetôk meg a spektrumukban (1.2., 1.3., 1.7. ábra). Azokat, amelyek esetében az semleges hidrogén vonalai nem jelennek meg az I-es, amelyeknél igen, a II-es típusba soroljuk. Az I-es típusúak közül azokat, amelyek spektrumában az Si II vonalai is megfigyelhetôk Ia típusúnak nevezzük. Azok, amelyeknél Si nem jelenik meg, de He I igen az Ib, amelyeknél pedig He sem az Ic típusúaknak csoportjába tartoznak (1.2. ábra). Nincs éles határ ez utóbbi két objektumtípus között, ezért gyakran hivatkoznak erre a csoportra Ib/c-ként.

A II-es típusúak közül sok SN fényessége 80-120 napon keresztül csak kismértékben változik (,plató”), ezek a II-P SN-k a leggyakoribbak a II-es típusúak között. Másik csoport- 


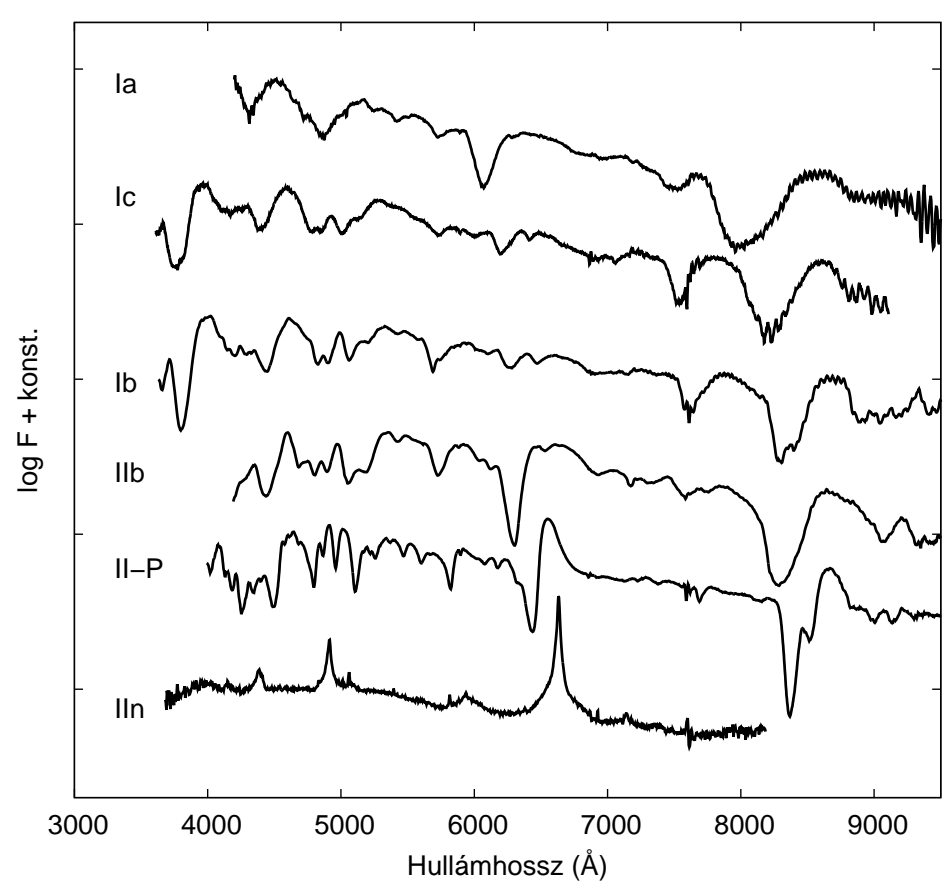

1.3. ábra. Példák a különböző típusú SN-k spektrumára. Ia - SN 2011fe (Vinkó és mtsai, 2012b), Ic - SN 2007gr (Valenti és mtsai, 2008b), Ib - 2009jf (Valenti és mtsai, 2011), IIb - SN2011dh (Vinkó és mtsai, 2012a), II-P - SN 1999em (Leonard és mtsai, 2002), IIn - SN 2010jl (Zhang és mtsai, 2012).

jukat, amelynek tagjai ugyanebben a fázisban egyenletes fényességcsökkenést mutatnak, II-L (,linear”) típusúaknak nevezzük. A IIn típusúak spektrumában a hidrogén keskeny emissziós vonalai figyelhetôk meg (1.3. ábra), melyek valószínúleg a ledobódó burok és az SN körül található anyag (circumstellar material, CSM) közötti kölcsönhatás eredményeként jelennek meg (Schlegel, 1990). A IIb típusú szupernóvák korai spektruma hasonló a többi II-éhez, de néhány nappal a robbanás után erős He I vonalak jelennek meg, a hidrogén vonalai pedig fokozatosan gyengülnek, akár el is tûnnek, így ezek a II-es és Ib típusok közötti átmeneti objektumnak tekinthetők (Filippenko és mtsai, 1993).

A robbanás fizikája alapján a szupernóvák két fố csoportba tartoznak. Az egyik esetben egy fehér törpe termonukleáris robbanása megy végbe (Ia típus), a másik esetben pedig egy nagy tömegú csillag magjának összeomlása (core collapse, $\mathrm{CC}$ ) vezet a szupernóva létrejöttéhez (II-es és Ib/c típus). Ha a nagy tömegú csillag körül a robbanás előtt hidrogénburok volt, akkor figyelünk meg II-es típusú $\mathrm{SN}$-t, ha pedig ezt - és esetleg az alatta található He réteget - már elvesztette, akkor Ib/c SN-ról beszélünk (1.7. ábra).

$\mathrm{Az} \mathrm{Ib} / \mathrm{c}$ típusú $\mathrm{SN}-\mathrm{k}$ röntgen- és gammatartományban is meglehetôsen fényesek lehetnek, köszönhetôen a ledobódó burok és a CSM kölcsönhatásának. Ezeken a hullámhosszakon a II-es típusúak esetében is megfigyelhetô némi felfényesedés közvetlenül a robbanás után, amit aztán gyors elhalványodás követ. A II-P és IIn SN-k késői fázisában előfordul a luminozitás kis mértékú növekedése a közeli és közepes infravörös tartományban, mely a keletkező pornak köszönhetô.

Egy újonan felfedezett, izgalmas csoportot alkotnak az ún. szuperfényes szupernóvák 
(superluminous supernovae, SLSNe). Ahogy nevükből is következik ezek legfőbb jellemzője nagy luminozitásuk - abszolút fényességük meghaladja a -21 magnitúdót - valamint a szokványostól eltérô spektrumuk. Szülőcsillaguk mibenléte és a robbanás fizikája azonban még nem ismert. Megfigyelt tulajdonságaik alapján úgy túnik, két fő csoportba sorolhatók. Egy részüknek korai fázisban jelentős az UV sugárzása, a spektrumuk nagyban hasonlít az Ic SN-k spektrumához, eleinte nem tartalmaz erôs vonalakat, és később sincsenek jelen sem a hidrogén, sem a hélium vonalai. Az ide tartozó objektumok eléggé egyformák. A másik fô csoportba tartozók spektrumában - hasonlóan a IIn SN-kéhez - megjelennek a hidrogén erős, keskeny emissziós vonalai, viszont az egyes objektumok fénygörbéje változatos lefutású, a csoport tagjainak megfigyelhető tulajdonságai nagy szórást mutatnak. Az SLSN-k manapság a szupernóvák kutatásának egyik legnagyobb nyitott kérdését jelentik, egyre több csoport fordít megkülönböztetett figyelmet rájuk (bővebb összefoglalásért lásd pl. Gal-Yam, 2012).

\subsubsection{Az egyes típusok elôfordulásának gyakorisága}

Az elmúlt években több, a szupernóvák felfedezésének dedikált égbolt-felmérô program is elindult, illetve fut a mai napig. Ilyen például - a teljesség igénye nélkül - a PTF (The Palomar Transient Factory ${ }^{1}$ ), a CRTS (Catalina Real-Time Transient Survey ${ }^{2}$ ), a ROTSE (Robotic Optical Transient Search Experiment ${ }^{3}$ ), LOSS (Lick Observatory Supernova Survey ${ }^{4}$ ) vagy a még fejlesztés alatt álló Pan-STARRS (Panoramic Survey Telescope \& Rapid Response System ${ }^{5}$ ). Ezeknek köszönhetően jelentősen megemelkedett a felfedezett SN-k száma, mely manapság évente több százra tehetô. Ekkora mintán már részletes statisztikai vizsgálatok elvégzése is lehetséges.

Az efféle tanulmányokhoz általában egy adott távolságon belül megtalálható objektumokat használják, azért, hogy a különböző kiválasztási effektusok hatását csökkentsék. Smartt és mtsai 2009-es munkájukban az 1998 és 2008 közötti 10.5 évben, 28 Mpc-nél közelebb talált SN-ket vették bele a mintájukba, és az egyes típusok relatív gyakoriságát vizsgálták. A minta összesen 132 db objektumot tartalmazott. Ezek negyede (27\%) Ia típusú volt, 66\%a pedig CC SN. A maradék néhány vagy nem volt egyértelmúen besorolható, vagy nem is szupernóva volt. A CC SN-k 59\%-a (azaz a teljes minta 39\%-a) volt II-P típusú, 29\%-a Ib/c, 5\%-a IIb, 4\%-a IIn és 3\%-a II-L típusú.

Li és mtsai (2011a) hasonló statisztika készítéséhez a LOSS által 1998 óta felfedezett SN-ket használták. A 60 Mpc távolságon belül lévő SN-k 24\%-a bizonyult Ia típusúnak, 19\%-a Ib/c-nek és 57\%-a II-esnek (1.4. ábra). Li és mtsai (2011a) a három típus különböző alcsoportjainak gyakoriságát is megvizsgálták. Az Ia SN-k jelentős része, 70\%-a normál Ia volt, a maradék az SN 1991bg- (15\%), SN 1991T- (9\%) vagy a SN 2002cx-csoportba (5\%) tartozott (ld. 1.2. fejezet). Az Ib/c SN-k felosztása nem egyszerú, sokszor nehéz óket egyik vagy másik csoportba besorolni. A tanulmány szerzői is kihangsúlyozzák, hogy a feltüntett arányok (1.4. ábra) inkább csak felsô korlátnak tekintendők. A II-es típusú SN-k 70\%-a a II-P típusba tartozott, (ez a teljes minta 40\%-át jelenti). 12\% volt a IIb, 10\% a II-L, míg 9\%

\footnotetext{
${ }^{1}$ http://www.astro.caltech.edu/ptf/

${ }^{2}$ http: //crts.caltech.edu/

${ }^{3}$ http: //www.rotse.net/

${ }^{4}$ http://astro.berkeley.edu/bait/public_html/kait_lwd.html

5 http://pan-starrs.ifa.hawaii.edu/public/
} 

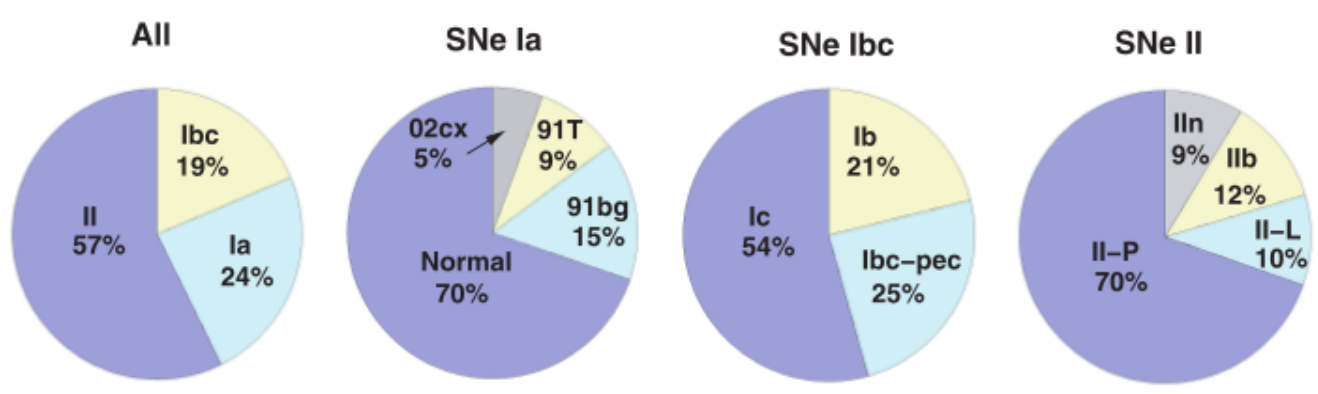

1.4. ábra. A különböző alcsoportba tartozó megfigyelt SN-k gyakorisága (Li és mtsai cikkének 9. ábrája). A bal szélen lévő ábra azt mutatja, hogy a teljes mintából mennyi SN tartozik a három fố típus egyikébe. A másik három ábra a fô csoportok ( $\mathrm{Ia}, \mathrm{Ib} / \mathrm{c}, \mathrm{II})$ altípusainak eloszlását mutatja.

a IIn típusú szupernóvák aránya.

Ugyan a két csoport különböző mintát használt - bár voltak átfedések -, különböző térbeli tartományon, az alapvető eredmények igen hasonlók. Minkét esetben a teljes minta kb. negyedét alkották az Ia, 40\%-át a II-P, ötödét az Ib/c típusú SN-k. A ritkább, IIb, IIn, II-L típusok esetében kissé nagyobbak az eltérések a két tanulmány eredményei között, ez valószínúleg annak köszönhető, hogy a minták nem tartalmaztak elég nagy számú objektumot.

\subsection{A szupernóvák fénygörbéje}

A különböző típusba tartozó szupernóvák fénygörbéje változatos képet mutat (1.5. ábra), lefutásuk sok fizikai paramétertől függ, ezért leírásuk meglehetôsen bonyolult feladat. Az alábbiakban olyan megoldásokról lesz szó, melyek néhány egyszerúsítő feltevéssel élve, analitikus módon kezelik ezt a problémát. A fénygörbét három részre osztva vizsgáljuk. A korai fázisban, amikor még optikailag vastag a burok, Arnett (1980) analitikus modellje használható. Az ezt követô idôszakban már a ${ }^{56} \mathrm{Ni}$ és az ${ }^{56}$ Co radioaktív bomlásából származó sugárzás dominál, majd a nikkel mennyiségének csökkenésével már csak a ${ }^{56}$ Co-bomlás játszik szerepet.

Arnett (1980) modellje során olyan atmoszférát vizsgált, melyben a sugárzás dominál, a burok gömbszimmetrikus és homológ módon tágul, az opacitás a Thomson-szórásból származik, valamint a radioaktív bomlás szerepe elhanyagolható. A táguló burokra ekkor felírható a termodinamika elsô fôtétele:

$$
\dot{E}+P \dot{V}=-\partial L / \partial m
$$

ahol $E$ a fajlagos belső energia, $P$ a nyomás, $V$ a fajlagos térfogat, $\partial L / \partial m$ az egységnyi tömegre eső luminozitás. Sugárzási energiatranszport esetén a fluxus:

$$
F_{\text {sug }}=-\frac{c}{\kappa \rho} \frac{d P}{d r}
$$


ahol $c$ a fénysebesség, $\kappa$ az abszorpciós koefficiens, $\rho$ a tömegsúrúség, $P$ pedig a nyomás, amely sugárzás által dominált közegben felírható $P=a T^{4} / 3$ alakban, ahol $T$ a hômérséklet, $a$ pedig a sugárzási állandó. Ekkor a luminozitás:

$$
L=-4 \pi r^{2} \frac{c}{3 \kappa \rho} \frac{\partial a T^{4}}{\partial r} .
$$

A fenti egyenletekből kiindulva, Arnett (1980) gondolatmenetét követve Chatzopoulos és mtsai (2012) a luminozitás időbeli változására a következő összefüggést kapták:

$$
L(t)=L(0) e^{-\left(t^{2} / t_{\mathrm{d}}^{2}+2 R_{0} t /\left(v t_{\mathrm{d}}^{2}\right)\right)},
$$

ahol $t_{\mathrm{d}}=\sqrt{2 \tau_{\mathrm{h}} \tau_{0}}, \tau_{0}$ a sugárzási diffúziós időskála, $\tau_{\mathrm{h}}=R_{0} / v$ a dinamikai időskála, $v$ a tágulás sebessége, $L(0)$ értéke pedig függ az $R_{0}$ kezdeti sugártól és energiától, a ledobódó burokra jellemző $\kappa$-tól, és a burok tömegétől. Tehát a luminozitás időbeli lefutása a Gaussgörbét követi, kezdetben lassú a változás, majd egyre gyorsabban csökken a fényesség.

A fenti modell jó közelítéssel visszaadja a szupernóvák észlelt fénygörbének alakját korai fázisban. Viszont nem veszi figyelembe a radioaktív bomlást, ami nagy szerephez jut, amint a burok elkezd átlátszóvá válni. A robbanás során keletkező ${ }^{56} \mathrm{Ni} 6,1$ napos felezési idôvel ${ }^{56}$ Co-ra bomlik, ami azután 77,1 napos felezési idôvel ${ }^{56} \mathrm{Fe}$-á alakul:

$$
\begin{aligned}
& { }_{28}^{56} \mathrm{Ni} \rightarrow{ }_{27}^{56} \mathrm{Co}+e^{+}+\mathrm{v}_{e}+\gamma \\
& { }_{27} \mathrm{Co} \rightarrow{ }_{26} \mathrm{Fe}+e^{+}+\mathrm{v}_{e}+\gamma
\end{aligned}
$$

Mindkét folyamat pozitron kibocsátásával jár, melyek - a $\gamma$-fotonokkal együtt - elnyelődnek a légkörben és felfütik azt, a keletkező termikus fotonok pedig szabadon távoznak a burokból. A folyamat eredményeképpen létrejövő fénygörbét a

$$
L(t)=S_{\mathrm{Ni}}+S_{\mathrm{Co}}+S_{\mathrm{Co}, e^{+}}
$$

egyenlet írja le (Valenti és mtsai, 2008a). Itt $S_{\mathrm{Ni}}$ a ${ }^{56} \mathrm{Ni}$ bomlásából származik:

$$
S_{\mathrm{Ni}}=M_{\mathrm{Ni}} \varepsilon_{\mathrm{Ni}} e^{-t / \tau_{\mathrm{Ni}}}
$$

ahol $M_{\mathrm{Ni}}$ a keletkezett ${ }^{56} \mathrm{Ni}$ tömege, $\varepsilon_{\mathrm{Ni}}$ a folyamat energiakeltési rátája (egységnyi tömegú ${ }^{56} \mathrm{Ni}$ által egységnyi idő alatt keltett energia), $\tau_{\mathrm{Ni}}$ pedig a bomlási állandó.

A ${ }^{56}$ Co bomlása során az energia $81 \%$-át a gamma-fotonok, míg a maradékot a pozitronok adják. Az ${ }^{56}$ Co-bomlás energiakeltési rátája:

$$
s=M_{\mathrm{Ni}} \varepsilon_{\mathrm{Co}}\left(e^{-t / \tau_{\mathrm{Co}}}-e^{-t / \tau_{\mathrm{Ni}}}\right) .
$$

A gamma-fotonok elnyelődésével termikus sugárzássá alakuló energia:

$$
S_{\mathrm{Co}}=0,81 s\left(1-e^{-(F / t)^{2}}\right) .
$$

A pozitronokból származó energia egy része ezek annihilációja során szabadul fel, míg kisebb töredékét a pozitronok kinetikus energája adja:

$$
S_{\mathrm{Co}, e^{+}}=\left[0,164 s\left(1-e^{-(F / t)^{2}}\right)\left(1-e^{-G / t)^{2}}\right)\right]+\left[0,036 s\left(1-e^{-G / t)^{2}}\right)\right] .
$$




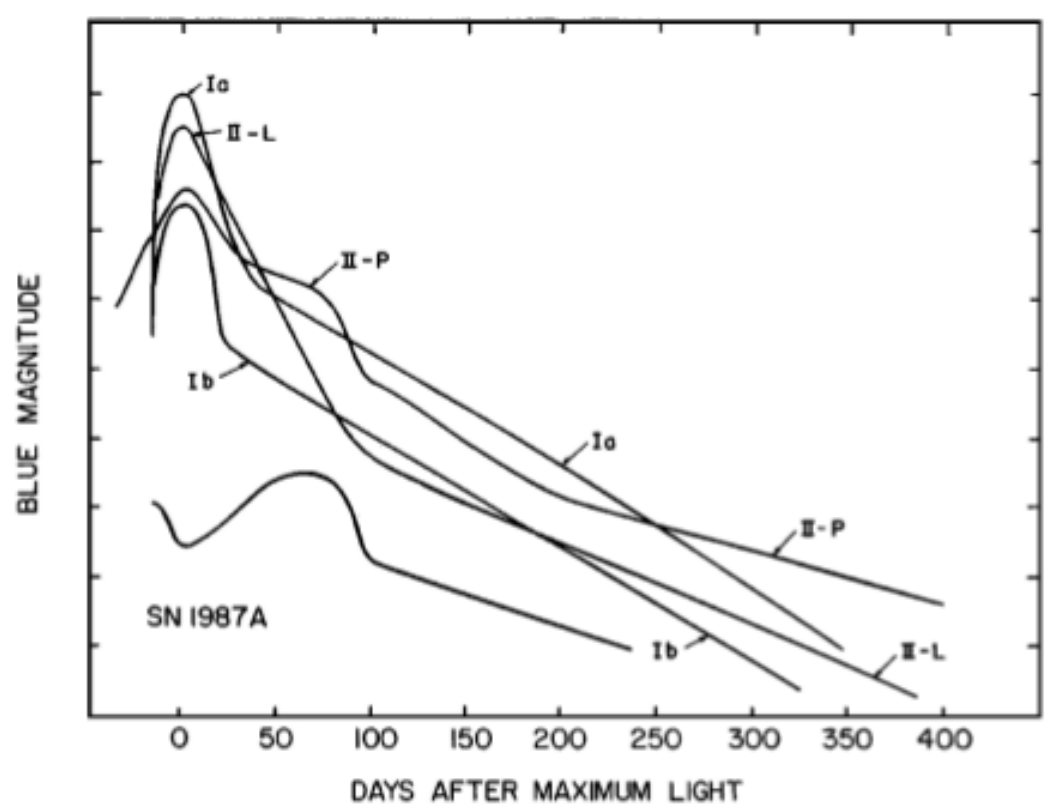

1.5. ábra. A különböző SN-k B szűrôs fénygörbéjének vázlatos összehasonlítása (Forrás: Filippenko, 1997).

Az $\left(1-e^{-(F / t)^{2}}\right)$ és $\left(1-e^{-(G / t)^{2}}\right)$ tagok annak figyelembevételéhez szükségesek, hogy a gamma-fotonoknak és a pozitronoknak nem a teljes energiája termalizálódik. $F$ és $G$ értéke a ledobott burok tömegének, a kinetikus energiának és az opacitásnak a függvénye (ld. Valenti és mtsai, 2008a).

Mivel a ${ }^{56} \mathrm{Ni} \rightarrow{ }^{56} \mathrm{Co}$ bomlás felezési ideje rövid, a nebuláris fázis késői szakaszában már a ${ }^{56}$ Co bomlás dominál. A még el nem bomlott atomok száma:

$$
N(t)=N_{0} e^{-l t},
$$

ahol $l$ állandó

$$
l=\frac{\ln 2}{\tau_{1 / 2}}
$$

alakú ( $\tau_{1 / 2}$ a bomlás felezési ideje). A szupernóva luminozitásának nagysága a bomlás sebességével arányos:

$$
L \sim \frac{d N}{d t}=l N_{0} e^{-l t}
$$

azaz a fényesség időbeli változása a

$$
\frac{d \log _{10} L}{d t}=-0,4342 \cdot l
$$

vagy - a bolometrikus magnitúdó és a bolometrikus luminozitás között fennálló, $M_{\text {bol }}=$ $-2,5 \log _{10} \frac{L}{L_{\odot}}+M_{b o l} \odot$ összefüggést felhasználva, ahol $M_{b o l} \odot=4,72$ magnitúdó - a

$$
\frac{d M_{\mathrm{bol}}}{d t}=1,0868 \cdot l
$$

képlettel írható le. ${ }^{56} \mathrm{Co} \rightarrow{ }^{56} \mathrm{Fe}$ bomlás esetén ez $0,0098 \mathrm{mag} / \mathrm{nap}$ fényességcsökkenést jelent, mely a legtöbb esetben jól egyezik a megfigyelésekkel. 


\subsection{Az Ia típusú szupernóvák}

Az Ia típusú szupernóvák mai ismereteink szerint olyan szénből és oxigénből álló fehér törpe csillagból keletkeznek, amelynek tömege meghaladja a Chandrasekhar-féle határtömeget (1,44 $\left.\mathrm{M}_{\odot}\right)$. A fehér törpe egy olyan maradványcsillag, amelyben a fúziós energiakeltés már leállt, az elfajult elektrongáz nyomása tart egyensúlyt a gravitációval. A Chandrasekharféle határtömeg az a felsố érték, ahol ez az egyensúly még fennállhat. Ha a tömeg ezt meghaladja, akkor a csillag magjában akkora lesz a nyomás, hogy beindul a szén és az oxigén fúziója, méghozzá olyan hevesen, hogy az a teljes csillagot megsemmisíti. A folyamat során nagy mennyiségú radioaktív ${ }^{56} \mathrm{Ni}$ jön létre.

Az Ia SN-k többségét elég egyforma tulajdonságok jellemzik, azonban jelentős az átlagostól eltérő objektumok száma is. Ezek három alapvető csoportba sorolhatók, a csoportokat egy-egy képviselőjükről nevezték el. A SN 1991T-csoport tagjai a fényesség-maximum környékén kékebbek, mint normál társaik, nagyobb luminozitásúak és kevesebb spektrumvonal látszik a színképükben. Az SN 1991bg-csoportba tartozók viszont jóval halványabbak a normál Ia-knál, gyorsabban halványodnak azoknál és erős spektrumvonalaik vannak (Filippenko, 1997). SN 2002cx-csoport tagjai szintén halványak, viszont spektrumuk az SN 1991T-csoport tagjaiéhoz hasonló.

Még nem sikerült közvetlenül észlelni egyetlen Ia SN szülőcsillagát sem, ezért egyelőre csak modellszámításokra támaszkodhatunk. Az elképzelés ezen SN-k származásáról az, hogy a fehér törpe egy kettős rendszer tagja. A társcsillag lehet egy fôsorozati vagy vörös óriás csillag, melyről anyag áramlik át a fehér törpére a rendszer belső Langrange-pontján keresztül (single-degenerate, SD, Whelan \& Iben, 1973). Egy másik modell szerint a társcsillag szintén egy fehér törpe csillag. A kettő egyre közelebb kerül egymáshoz, majd összeolvadnak, ekkor következik be a robbanás (double-degenerate, DD, Iben \& Tutukov, 1984; Webbink, 1984).

Arra, hogy a két modell közül melyik a helyes, még nincs válasz, egyes elképzelések szerint mindkét variáció megvalósulhat, ezzel magyarázható az objektumok tulajdonságainak megfigyelt diverzitása. A DD, valamint a SD rendszerek közül a fősorozati tárcsillaggal rendelkezőknél is nehézséget jelent a tagok kis mérete és luminozitása, emiatt ugyanis a szülőcsillag közvetlen detektálása még közeli galaxisok esetében sem megvalósítható. Az utóbbi évtizedek legközelebb felbukkant Ia SN-e, az SN 2011fe esetében például a vizsgálatok arra jutottak, hogy a társcsillag lehet akár fősorozati, akár fehér törpe csillag, egyedül a fényes vörös óriás vagy a héliumban gazdag társcsillag lehetôségét sikerült kizárni az SN környezetérôl korábban, a robbanás bekövetkezte előtt készült felvételek segítségével (Nugent és mtsai, 2011; Li és mtsai, 2011b).

\subsection{A nagy tömegú csillagok összeomlásával keletkezố szu- pernóvák}

A magösszeomlással keletkező szupernóvák közé az Ib/c és a II-es típusú SN-k tartoznak. Ezekról már valamivel tisztább a fizikai kép, mint az Ia SN-k esetében, köszönhetóen többek között annak is, hogy már számos esetben sikerült közvetlenül azonosítani a szülőcsillagot archív HST felvételeken (Smartt, 2009). A CC SN-k nagy tömegú csillagok össze- 


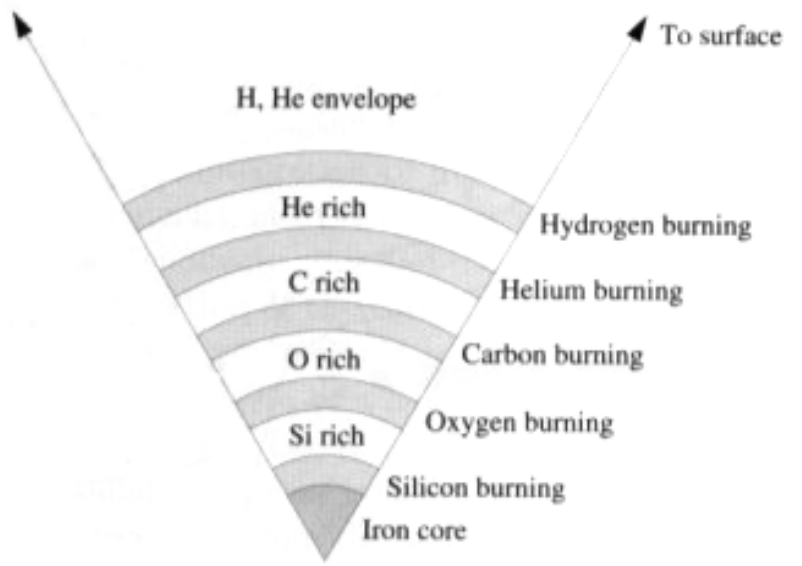

1.6. ábra. A nagy tömegú csillagok hagymahéjszerú belsô szerkezete életük végén (Forrás: Carroll \& Ostlie, 1996)

omlásakor keletkeznek, és fizikai tulajdonságaik nagy skálán változhatnak. Az alábbiakban szó lesz röviden a nagy tömegú csillagok fejlődésérôl, az ennek végén bekövetkező robbanás fizikájáról és a különböző SN-típusokról is.

\subsubsection{A nagy tömegú csillagok fejlődése és halála}

A csillagok fejlődésének menetét elsősorban tömegük nagysága határozza meg. Egy csillag megszületésén azt a pillanatot értjük, amikor a gázgömb magjában beindul a hidrogén fúziója. Azok a csillagok, amelyek magjában ezen reakció játszódik le éppen, a Hertzsprung-Russell-diagramon (HRD) nagyjából egy egyenes mentén helyezkednek el, ez a fősorozat. Amíg a magban rendelkezésre áll a hidrogén, addig a csillagok a fôsorozaton maradnak, ennek kifogyása után megkezdődik a fejlődés következő fázisa.

Ahogy a magból kifogy a hidrogén, a csillag elkezd összehúzódni. Ezt követően indul be a magot körülvevő hidrogénburokban a fúzió. Ahogy a burokban a hidrogén egyre fogy, úgy nô a magban a hélium mennyisége. Ha ez elér egy kritikus tömeget, akkor a mag elkezd összehúzódni, majd a megfelelően magas hőmérséklet elérésével megkezdődik a hélium fúziója. Ennek során a magban szén és oxigén keletkezik. Ahogy a hélium elfogy, a mag újra elkezd összehúzódni. Kis tömegú csillagok esetében az összehúzódást az elektronok elfajulása megállítja, fehér törpe csillag keletkezik.

A $8 \mathrm{M}_{\odot}$-nél nagyobb tömegú csillagok esetében viszont a magban a hőmérséklet és a sûrúség elég naggyá válhat ahhoz, hogy beinduljon a szén és az oxigén fúziója, majd egymás után a nehezebb elemeké is, míg végül kialakul az 1.6. ábrán látható hagymahéjszerú, réteges szerkezet. Ekkor a Si-héjban zajló égésnek köszönhetôen a vasmag tömege egyre nô, addig, míg el nem ér egy kritikus értéket. Ekkor a mag elkezd összehúzódni. A megnövekedett hőmérsékletnek köszönhetően beindul a fotobomlás, ami energiát von el a magból és neutronok keltésével jár:

$$
\begin{aligned}
& { }_{26}^{56} \mathrm{Fe}+\gamma \rightarrow 13{ }_{2}^{4} \mathrm{He}+4 n \\
& { }_{2}^{4} \mathrm{He}+\gamma \rightarrow 2 p^{+}+2 n
\end{aligned}
$$


A magban található szabad elektronok és a keletkező protonok találkozásakor bekövetkező inverz béta-bomlás szintén energia elvezetésével és neutrínók keletkezésével jár:

$$
p^{+}+e^{-} \rightarrow n+v_{e}
$$

Ahogy az elfajult elektronok által szolgáltatott nyomás megszúnik, a mag szabadesési időskálán elkezd homológ módon összeomlani. Amikor a legbelsố részeken elég nagy lesz a súrúség $\left(\rho \sim 10^{14} \mathrm{gcm}^{-3}\right)$, a neutronok elfajultá válnak, és az így keletkező összenyomhatatlan magról a külsố részek mintegy visszapattannak. A keletkező lökéshullám elkezd kifelé terjedni, ami a burok ledobódását eredményezi. A burok belsố része eközben - a lökéshullámnak köszönhetôen - felmelegszik, beindul benne a fúzió, amelynek során vasnál nehezebb elemek, többek között ${ }^{56} \mathrm{Ni}$ keletkezik. Amint a lökéshullám eléri az optikailag vékony rétegeket, a szupernóva láthatóvá válik, UV- (időnként lágy röntgen-) és optikai hullámhossztartományban észlelhetô lesz. Eközben $10^{51}$ erg nagyságrendú energiamennyiség szabadul fel.

Ha a csillag tömege nem volt túl nagy $\left(M_{\text {ZAMS }}<25 \mathrm{M}_{\odot}\right)$, akkor a visszamaradó neutrongömb stabillá válik és neutroncsillag keletkezik. Ha csillag eredeti tömege ennél nagyobb, akkor az elfajult neutronok nyomása nem tud egyensúlyt tartani a gravitációval, az összeomlás tovább folytatódik, fekete lyuk jön létre.

\subsubsection{Az Ib/c típusú szupernóvák}

Az Ib/c szupernóvák esetében is próbálkoztak ezek szülőcsillagait archív HST-felvételeken azonosítani, sikertelenül, viszont néhány alkalommal sikerült felsố becslést adni a tömegükre (Smartt, 2009).

Az egyik elfogadott modell szerint ezek az SN-k olyan nagy tömegú csillagokból keletkeznek, amelyek fejlődésük során jelentős tömegvesztésen mennek keresztül (csillagszél), így életük végére a teljes külső hidrogénburkot - Ic SN-k esetén az alatta elhelyezkedő Heréteget is - elvesztik. Ezzel a modellel viszont csak az Ib/c SN-k egy részének megfigyelhetô tulajdonságait lehet megmagyarázni. Nomoto és mtsai (1995) munkájuk során arra a következtetésre jutottak, hogy a szülő́csillag olyan 8-10 $\mathrm{M}_{\odot}$ tömegú csillag is lehet, amely egy kölcsönható kettős tagja. Ekkor a külsố hidrogénburkot a társcsillaggal való interakciónak köszönhetően veszti el.

Egyes Ic szupernóvák rendkívül fényesek lehetnek, és spektrumukban jelentősen kiszélesedett vonalakat figyelhetünk meg (hipernóvák). Több esetben előfordult, hogy egy ilyen jellegû SN pozíciója egy nem sokkal korábban észlelt hosszú gammakitörésével (long-duration gamma-ray burst, LGRB) esett egybe. Az első ilyen példa a GRB 980425/SN 1998bw páros volt (Galama és mtsai, 1998). Ilyen objektum volt még a GRB 030329/SN 2003dh (Hjorth és mtsai, 2003), a GRB 031203/SN 2003lw (Malesani és mtsai, 2004), a GRB 060218/SN 2006aj (Mazzali és mtsai, 2006), a GRB 100316D/SN 2010bh (Starling és mtsai, 2011). Ugyanakkor nem mindegyik ilyen típusú Ic szupernóva esetében sikerült előzetesen GRB-t detektálni (pl. SN 1997ef, Iwamoto és mtsai, 2000; SN 2002ap, Mazzali és mtsai, 2002). A magyarázat az lehet, hogy ekkor a robbanás kevésbé volt energetikus, vagy kevésbé aszimmetrikus, mint hasonló társaik esetében (Nomoto és mtsai, 2007; Mazzali és mtsai, 2007). 


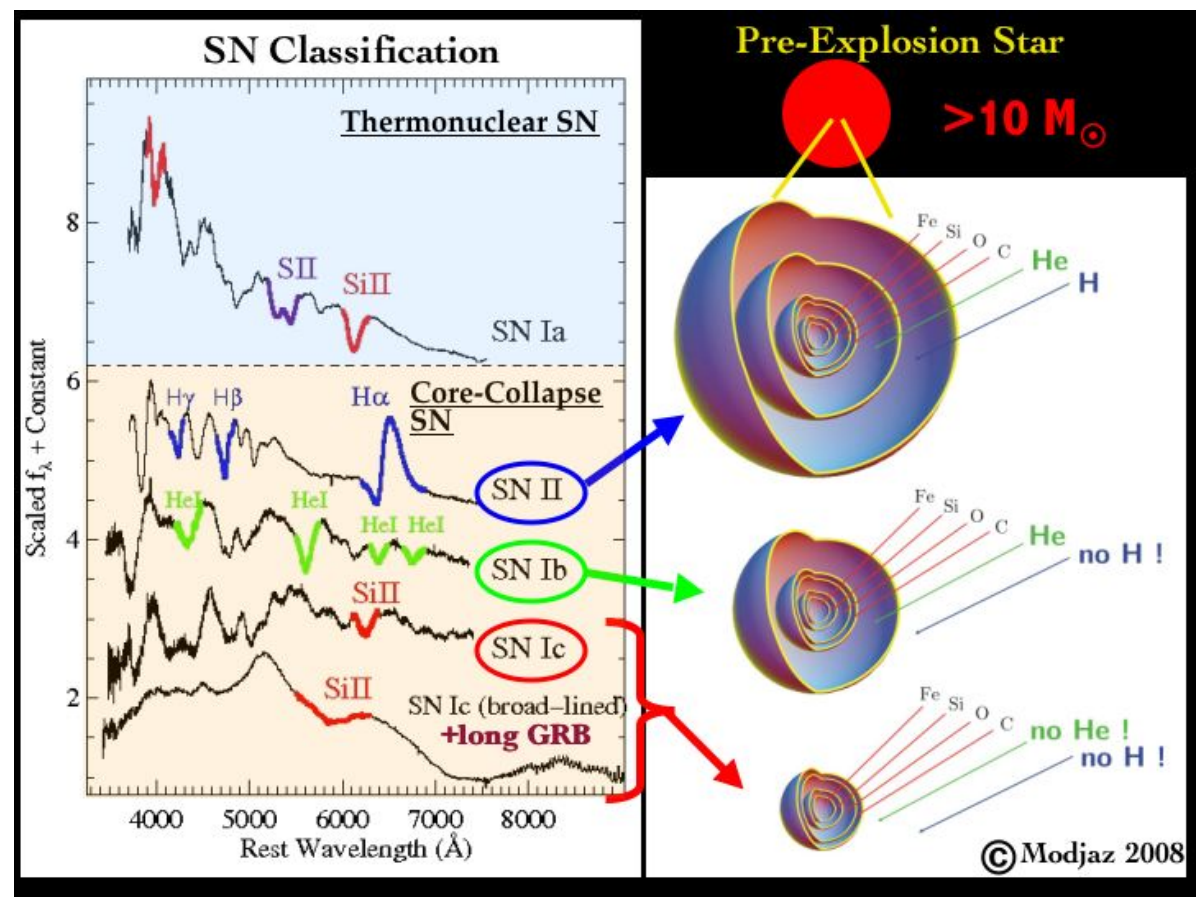

1.7. ábra. A különböző típusú $\mathrm{SN}-\mathrm{k}$ spektruma és a CC SN-k belső szerkezete (Forrás: Modjaz, 2011)

\subsubsection{II-es típusú szupernóvák}

A II-es típusú szupernóvák - amelyek besorolása a spektrumban fellelhető hidrogénvonalak segítségével történik - többféle altípusba tartozhatnak, bár ezek közül a II-P típusúak messze a leggyakoribbak (ld. 1.1.1. fej.).

A II-P SN-k között mára már számos olyan van, amelyel pozíciójáról jó minőségú, optikai vagy NIR tartományban készült archív felvételek állnak rendelkezésre (Smartt és mtsai, 2009; Smartt, 2009). Ezeken a képeken egyes esetekben azonosítható volt az a csillag, amely az SN legvalószínúbb szülőcsillaga. Ezen csillagok fényességének és hőmérsékletének meghatározásával valamint különböző csillagfejlődési modellek eredményeinek felhasználásával következtetni lehet a tömegükre. Smartt és mtsai 2009-ben összefoglalták az ezen a területen elért eredményeket. Azt találták, hogy 20 II-P SN esetében álltak rendelkezésre elegendően jó minőségú archív felvételek, ebből 5 SN-nak egyértelmúen lehetett detektálni a szülőcsillagát, ami mind az 5 esetben egy vörös szuperóriás (red supergiant, RSG) volt. Néhány esetben a szülő́csillag egy csillaghalmazhoz tartozott, ezért nem lehetett azonosítani, a leggyakrabban pedig nem látszott a felvételeken a szülő́csillag, ezért csak a tömeg felsô korlátját lehetett megbecsülni (1.8. ábra). Smartt és mtsai (2009) azt is megállapították, hogy a II-P típusú SN-k szülő́csillagainak tömege minimum $M_{\text {ZAMS }} \sim 8_{-1.5}^{+1} \mathrm{M}_{\odot}$, míg a felső határ $16,5 \pm 1,5 \mathrm{M}_{\odot}$ nagyságúnak adódott. Az RGB csillagok tömegének felsô határa $25 \mathrm{M}_{\odot}$ körül van, ezért érdekes kérdés, hogy miért nem sikerült $17-25 \mathrm{M}_{\odot}$ közötti tömegú szülő́csillagot felfedezni (,the red supergiant problem”). Smartt és mtsai (2009) szerint ennek két oka lehet. Az egyik, hogy a szülőcsillagok tömegét alábecsülték pl. a jelen lévő nagyobb mennyiségú por miatt. A másik lehetőség, hogy az ilyen tömegú csillagok nem II-P, hanem más típusú SN-ként fejezik be életüket. Egy idén felfedezett II-P szupernóva, az SN 2012aw - amely 


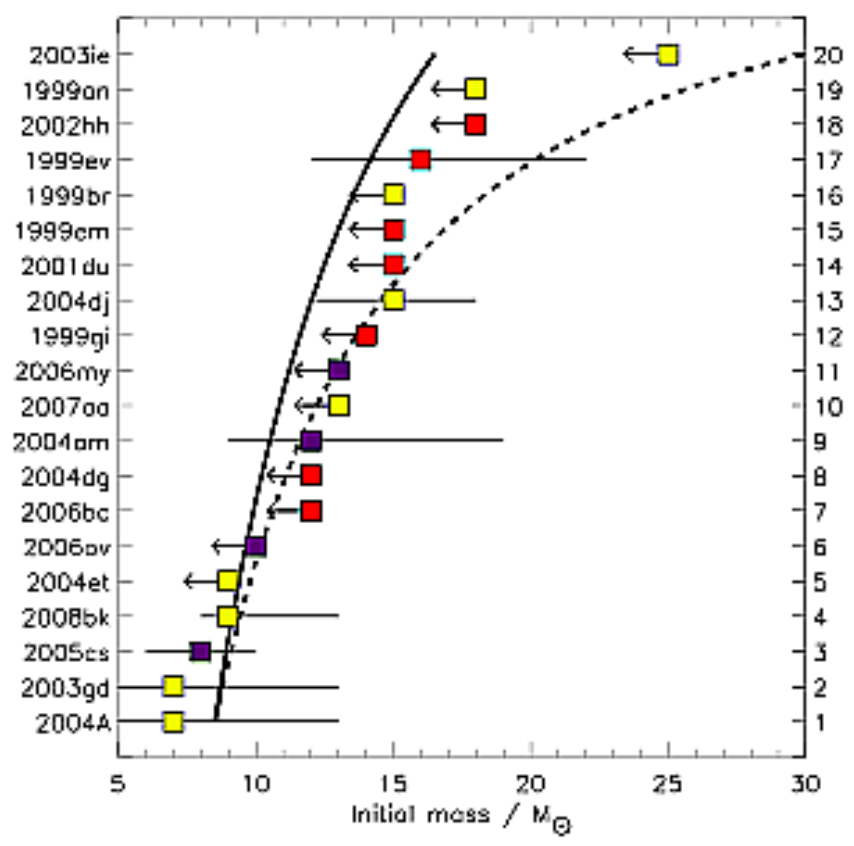

1.8. ábra. Szupernóvák szülő́csillagainak archív HST-képek alapján megállapított tömege (Smartt, 2009).

az M 95 jelû́ közeli galaxisban bukkant fel - az első, amely szülőcsillagának tömege ebbe a

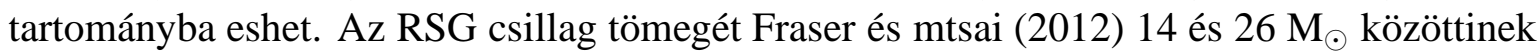
becsülték, míg Van Dyk és mtsai (2012) $M_{\text {ZAMS }}=15-20 \mathrm{M}_{\odot}$ értéket kaptak.

A II-P típusú SN-k fizikájának megértésében rendkívül nagy szerepe volt az SN 1987A jelû́ objektumnak. Ez ugyan nem egy átlagos II-P SN volt (ehhez hasonlót azóta is csak néhányat fedeztek fel, lásd pl. az Appendix A-t Pastorello és mtsai 2012-es cikkében), mégis a róla készült hatalmas mennyiségú és jó minőségú adat sok jelentôs eredményt hozott. A fénygörbe és a spektrum hidrodinamikai modellezésével lehetővé vált a különböző elméletek tesztelése és a megfelelő modell kiválasztása. Bebizonyosodott, hogy a luminozitás elsôsorban a ${ }^{56} \mathrm{Ni}$ radioaktív bomlásából származik (1.2. fej.), valamint a spektrumok modellezésével a kémiai összetétel részletes elemzésére is sor kerülhetett. (pl. Dopita, 1988; Woosley, 1988; Utrobin 1993, 2005; Mitchell és mtsai, 2002; Dessart \& Hillier, 2005a). Mivel az SN maradványa a mai napig látható, tanulmányozásával a késői fázis során végbemenő folyamatokról is újabb és újabb ismeretekre teszünk szert.

Egy másik fontos szupernóva az SN 1999em jelú, normál II-P típusú objektum volt, amelynek a fénygörbéjét és spektrumát szintén többen modellezték, és az ennek során született eredmények jelentősen hozzájárultak a II-P SN-kről kialakuló fizikai képhez (pl. Leonard és mtsai, 2001; Dessart \& Hillier, 2006; Utrobin, 2007; ld. még a 4.1. fej.).

A II-P típusú SN-k fénygörbéje a robbanás utáni gyors felfényesedést követően 80120 napig közel konstans fényességú a $V, R$ és $I$ szürők hullámhossztartományán (plató fázis). A plató létrejöttének az oka a vastag hidrogénburok, amely a szülőcsillagot a robbanás pillanatában körülvette. A robbanás során a frissen keletkezett szupernóván végigfutó lökéshullám felmelegíti a burkot, emiatt a teljes hidrogénréteg ionizált állapotba kerül. Eb- 


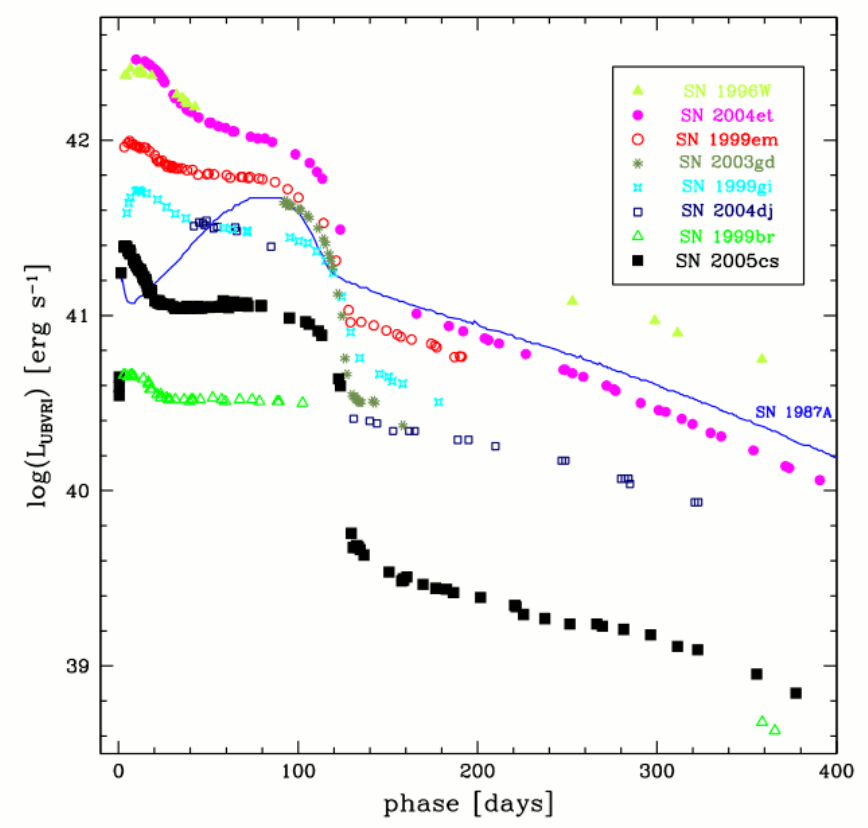

1.9. ábra. A II-P típusú szupernóvák abszolút fényessége meglehetôsen nagy szórást mutat. Az ábrán több ilyen típusú SN luminozitásának időbeli lefutása látható. (Forrás: Pastorello és mtsai, 2009)

ben az állapotban a burok optikailag vastag, szinte teljesen átlátszatlan. Ahogy az SN tágul, a burok adiabatikusan hûlni kezd. Amikor a hőmérséklet a hidrogén rekombinációjához szükséges szintre csökken, az opacitás hirtelen leesik, a réteg átlátszóvá válik. A rekombinációs hullám kívülrôl befelé halad, ezért egyre beljebb és beljebb látunk az atmoszférában, ami kompenzálja a tágulás miatti felületnövekedést, tehát a mért luminozitás nem változik jelentôsen. Körülbelül 100 nap elteltével már a teljes hidrogénburkon keresztülér a rekombinációs hullám, ekkor az SN atmoszférája teljesen átlátszóvá válik, véget ér a plató-fázis. A fényesség egy hirtelen esést követően egyenletes ütemben csökken. Az energiát ekkor már csak a ${ }^{56} \mathrm{Ni}$ és a ${ }^{56}$ Co radioaktív bomlása szolgáltatja.

Az egyes objektumok esetében a fénygörbe lefutásában akadnak különbségek. A plató fázis időbeli hossza a hidrogénburok vastagságától és a robbanás energiájától függ, míg a nebuláris fázisban a fényesség a keletkezett ${ }^{56} \mathrm{Ni}$ tömegére utal. Jelentős eltérések vannak az SN-k luminozitásában is (1.9. ábra). Az általában „,normál” II-P SN-nek tekintett SN 1999em bolometrikus luminozitása a plató fázis során $\sim 10^{42} \mathrm{erg} / \mathrm{s}$ (Bersten \& Hamuy, 2009) volt. Az SN 2004et ennél nagyjából kétszer volt fényesebb (Maguire és mtsai, 2010b). Több olyan SN van, ami viszont jóval halványabbnak bizonyult. Ilyen volt például az SN 1997D (Turatto és mtsai, 1998), az SN 1999br (Hamuy \& Pinto, 2002), amely az SN 1999em-nél 25-ször volt halványabb, az SN 2005cs (Pastorello és mtsai, 2009; Takáts \& Vinkó, 2006) - amelyról részletesen lesz szó ebben a dolgozatban -, és az SN 2009md (Fraser és mtsai, 2011). Ezek esetében a robbanás során felszabaduló energia és a keletkezô nikkel tömege is kisebb volt, mint normál társaiknál, spektrumvonalaik pedig keskenyebbek voltak és kisebb sebességet mutattak. Van néhány olyan is, amely a normál és a halvány SN-k közötti luminozitás- 


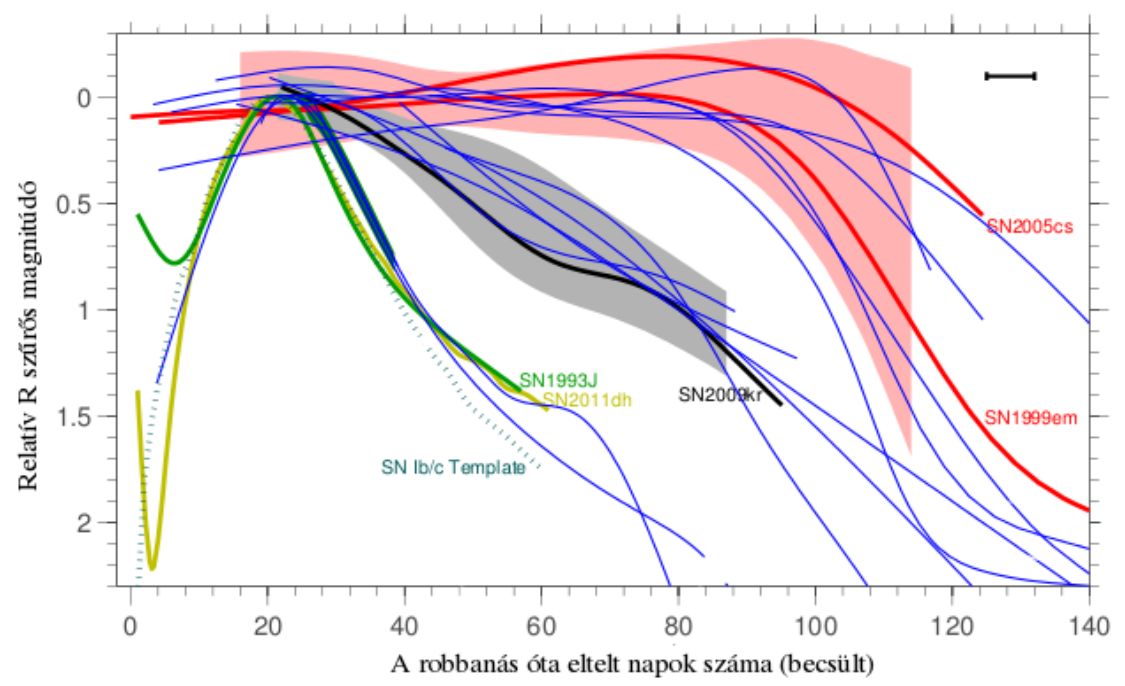

1.10. ábra. A II-P (piros), II-L (szürke) és IIb (zöld) típusú SN-k fénygörbéi (Arcavi és mtsai, 2012), melyek jól elkülöníthető csoportokba rendeződnek.

tartományba esik. Ilyen az SN 2008in (Roy és mtsai, 2011) és az SN 2009N (Takáts és mtsai, készülőben).

A II-P SN-knél sokkal ritkábban előforduló IIL és IIb típusú szupernóvák keletkezését általában azzal magyarázzák, hogy a csillag légköre jelentősen kevesebb hidrogént tartalmazott. Így ugyan megjelennek a vonalai a spektrumban, ám a plató nem figyelhetô meg a fénygörbén, fokozatosan csökken a fényesség. Egyes elképzelések szerint ezek és az Ib/c típusúak egy „,sorozat” tagjainak tekinthetők (II-P $\rightarrow$ IIL $\rightarrow$ Ilb $\rightarrow$ Ib $\rightarrow$ Ic), hasonló objektumoknak egyre vékonyabb hidrogénburokkal, folytonos átmenettel az egyik típusból a másikba. Azonban Arcavi és mtsai (2012) nagyszámú II-es típusú SN fénygörbéjét tanulmányozva azt találták, hogy ez a folytonosság hiányzik, a különbözô objektumok jól megkülönböztethetô csoportokat alkotnak (1.10. ábra). A II-P, IIL és IIb SN-k fénygörbéi egymástól könnyen elkülöníthetőek, nincs átmenet köztük. Ez pedig felveti a kérdést, hogy lehetnek-e tényleg ugyanazon csoport folytonos eloszlású fizikai paraméterekkel jellemezhetô tagjai. 


\section{2. fejezet}

\section{Távolságmérés szupernóvákkal}

A távolságmérés a csillagászatban rendkívül fontos és sok nehézséget rejtő probléma. Több megoldás született és születik továbbra is arra, hogy különbözô csillagászati objektumok miként alkalmazhatók erre a célra. A legtöbb távolságmérési módszer egymásra épül: egy új módszert ismert távolságú objektumok segítségével kalibrálunk, majd ezt a módszert távolabbi objektumokra alkalmazzuk, amelyekkel aztán újabb módszert kalibrálunk. Így épül fel a csillagászati távolságlétra.

Ahogy a mérendô távolságok nőnek, úgy csökken az alkalmas objektumok száma. Távoli galaxisok esetében, amelyek egyedi csillagokra már nem bonthatók fel, vagy magának a galaxisnak bizonyos fizikai tulajdonságaiból következtethetünk a távolságára (ilyen pl. a Tully-Fisher-módszer, Tully \& Fisher, 1977), vagy egy felbukkanó szupernóva oldhatja meg ezt a problémát.

Távolságmérésre mind az Ia, mind pedig a II-es típusú szupernóvák alkalmasak lehetnek. Az előbbieket most csak röviden tárgyalom, míg az utóbbiakról részletesen lesz szó.

\subsection{Az Ia típusú SN-k távolsága}

Azt, hogy a szupernóvák standard gyertyák (azaz egyforma az abszolút fényességük), és ezáltal távolságmérésre alkalmasak lehetnek, Walter Baade vetette fel elsőként (Baade, 1938). 1960-ban Hoyle és Fowler arra a következtetésre jutottak, hogy az I-es típusú szupernóvák kettős rendszerekben megtalálható fehér törpe csillagokból keletkeznek. A robbanás akkor következik be, ha tömegátadás következtében a fehér törpe tömege eléri a kritikus, ún. Chandrasekhar-féle határtömeget, amelynek nagysága 1,44 $\mathrm{M}_{\odot}$ (Hoyle \& Fowler, 1960). Ha pedig minden fehér törpe egyforma tömeg elérése esetében robban fel, akkor fényességüknek is egyformának kell lenniük. Az abszolút $(M)$ és a látszó $(m)$ fényesség összehasonlításával pedig a $D$ távolság (Mpc-ben kifejezve) egyszerúen meghatározható:

$$
m-M=25+5 \cdot \log D .
$$

Mára a tudásunk ezekről az SN-król sokat bővült. Az Ia típusú szupernóvák szülőobjektumaira még mindig a kettôs rendszerben található fehér törpe a legjobb modell - bár közvetlen azonosítás eddig még nem történt (ld. 1.3 fej.). Az viszont már bebizonyosodott, hogy az Ia típusú SN-k ugyan nem standard gyertyák, de fénygörbéjük alakjából következtethetünk az abszolút fényességükre. 

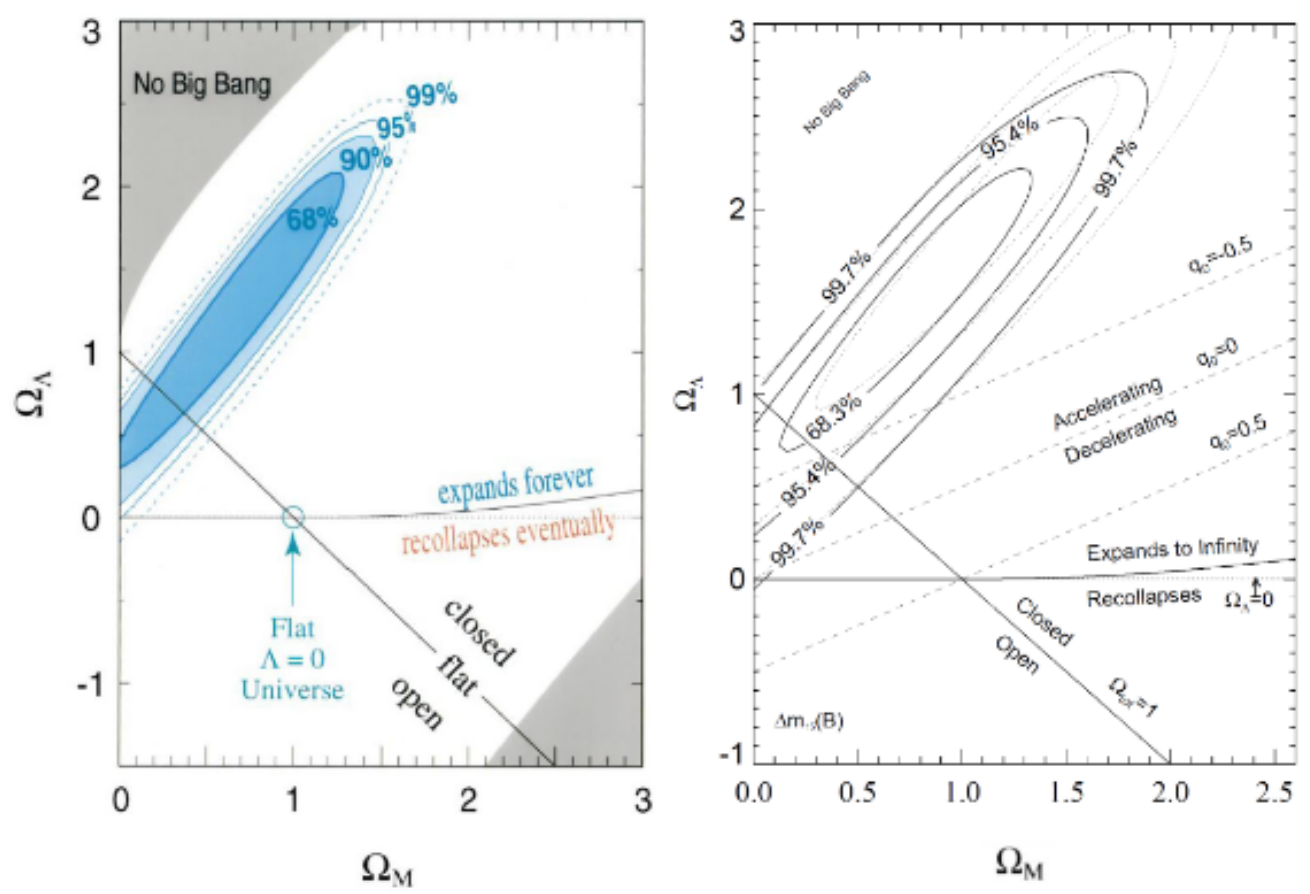

2.1. ábra. Mind Riess és mtsai (jobbra), mind Perlmutter és mtsai eredményei (balra) arra utalnak, hogy az Univerzum gyorsulva tágul ${ }^{8}$.

Az 1988-ban indult Supernova Cosmology Project ${ }^{6}$, amelyet Saul Perlmutter vezetett, valamint az 1994-ben Brian Schmidt által alapított High-z Supernova Search Team ${ }^{7}$ célja az volt, hogy minél több távoli Ia SN-t fedezzenek fel korai fázisban, és hogy a felvett fénygörbék segítségével olyan pontosan mérjék meg ezek távolságát, hogy az alkalmas legyen kozmológiai modellek tesztelésére. Mindkét csoport 1998-ban küldte be publikálásra az eredményeit (Riess és mtsai, 1998; Perlmutter és mtsai, 1999). A két csoport egymástól függetlenül mutatta ki, hogy az Univerzum gyorsulva tágul (2.1. ábra; magyar nyelvú összefoglaló pl. Szalai, 2011). Az eredmény elismeréseként Perlmutter, Schmidt és Adam Riess megkapták a 2011-es fizikai Nobel-díjat.

Az Ia SN-kkel történő távolságmérésre manapság használt módszerek mindegyike empirikus jellegú. Azt a megfigyeléseken alapuló tényt használják fel, hogy a nagyobb luminozitású SN-k fényessége gyorsabban változik, mint a halványabbaké és a maximum után kékebbek azoknál. Perlmutter és mtsai (1999) az ún. nyújtási módszert használták, mely szerint ha az idôtengelyt átskálázzuk (a fénygörbét ementén megnyújtjuk vagy összenyomjuk), akkor a különböző SN-k $B$ szűrôs fénygörbéi egymásra illeszthetőek, a skálázás mértékéből pedig meg lehet határozni az abszolút fényességet. Riess és mtsai (1998) a $\Delta m_{15}$ módszert (Phillips, 1993) és az MLCS (multi-color light curve shape, Riess és mtsai, 1996) módszert használták. Előbbi esetében azt vetik össze, hogy a $B$ szúrőn át mért fényesség a maximumot követő 15 napban milyen mértékben változott, a halványodási ütem ugyanis összefügg az

\footnotetext{
${ }^{6}$ http: // supernova.lbl.gov/

${ }^{7}$ http://www. cfa.harvard.edu/supernova/Highz.html

8 a kép forrása: http://www.nobelprize.org/nobel_prizes/physics/laureates/2011/press $\backslash$ - . html/ad\-vanced-physicsprize2011.pdf
} 
abszolút fényességgel. Az MLCS módszer esetében a fénygörbe alakját a Johnson-féle $B, V$, $R$ és $I$ szürők mindegyikén át vizsgálják, ezáltal több paramétert is illesztenek egyidejúleg.

Manapság a két leggyakrabban használt, bárki számára elérhetô fénygörbeillesztő módszer a MLCS $2 \mathrm{~K} 2^{9}$ (Jha és mtsai, 2007) és a SALT $2^{10}$ (Guy és mtsai, 2007). Mindkét módszer kalibrációja nagyszámú SN észlelt fénygörbéjén alapul. Kessler és mtsai (2009) a Sloan Digital Sky Survey-II Supernova Survey ${ }^{11}$ (SDSS-II) szupernóva észleléseit felhasználva, és alkalmazva a két módszert azt találta, hogy a két esetben kapott eredmények némiképp eltérnek. Mivel a mintában kevés volt az egészen közeli SN, valamint mivel a vörösödés mértékét (melytôl mindkét módszer esetében jelentősen függ a távolság) csak bizonytalanul lehet meghatározni, nehéz megállapítani, hogy a tapasztalt eltérést mekkora mértékben okozza a kalibráció pontatlansága.

Vinkó és mtsai (2012b) az M101-ben felbukkant, SN 2011fe jelú Ia SN segítségével tesztelték a két módszert. Ez az SN nagyon közeli, teljesen átlagosnak mondható objektum, amelynek ráadásul nagyon kis mértékú a vörösödése $\left(A_{V} \sim 0,04\right.$ mag). Ennek köszönhetôen kivételesen alkalmas az eljárások konzisztenciájának vizsgálatára. Vinkó és mtsai (2012b) azt találták, hogy a két módszer némileg eltérô eredményt ad: az MLCS2K2 használatával a távolságmodulusra $\mu=29,21 \pm 0,07$ mag $(D=6,95 \pm 0,23 \mathrm{Mpc})$ értéket kaptak, míg a SALT2 alkalmazása a $\mu=29,05 \pm 0,07$ mag $(D=6,46 \pm 0,21 \mathrm{Mpc})$ távolsághoz vezetett.

A legújabb eredmények szerint közeli infravörös (near-infrared, NIR) tartományba eső észlelések sokkal inkább alkalmasak az Ia SN-k távolságának meghatározására, mint az optikai hullámhosszakon végzett mérések, mivel a csillagközi por hatása itt jóval kevésbé jelentôs (Meikle, 2000; Krisciunas és mtsai, 2004; Folatelli és mtsai, 2010; Kattner és mtsai, 2012). Az optikai észlelések esetében ugyanis az extinkció miatt szükséges korrekció jelenti az egyik legfőbb hibaforrást a kalibráció során, így ennek kiküszöbölése jelentősen növeli a pontosságot. Elsôsorban a $J$ és $H$ szúrôs észlelések túnnek a legalkalmasabbnak a távolságmeghatározásra, az SN-k fényességeloszlásának ekkor a legkisebb szórása (BaroneNugent és mtsai, 2012). Ezen a téren jelenleg folynak a vizsgálatok, az ezzel foglalkozó kutatók igyekeznek minél több, minél távolabbi Ia szupernóva NIR fénygörbéjét kimérni, hogy felhasználásukkal a kalibrációt tovább lehessen pontosítani.

\subsection{A II-es típusú szupernóvák távolsága - a táguló foto- szféra módszer}

Az eredetileg pulzáló változócsillagok méretének meghatározására szolgáló Baade-Wesselink-módszert Kirshner \& Kwan (1974) kísérelte meg először szupernóvák távolságmérésére alkalmazni. Cikkükben két objektumot vizsgáltak, az NGC 1058 jelú galaxisban található SN 1969L-et és az SN 1970G-t, amely az M101-ben bukkant fel. Utóbbi távolságát $D_{\mathrm{M} 101}=6 \pm 3 \mathrm{Mpc}$ értékúnek állapították meg. Érdekesség, hogy ebben galaxisban nemrég egy Ia típusú szupernóvát is felfedeztek, az SN 2011fe-t (ld. előző fejezet), amelynek segítségével az M101 távolságát Vinkó és mtsai (2012b) 6,6 0,5 Mpc nagyságúnak mérték.

\footnotetext{
${ }^{9}$ http://www.physics.rutgers.edu/ saurabh/mlcs 2 k2

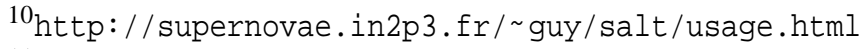

${ }^{11}$ http://www.sdss.org/supernova/aboutsupernova.html
} 
A Kirshner \& Kwan (1974) által használt módszer - amely táguló fotoszféra módszer (expanding photoshere method, EPM) néven terjedt el - továbbfejlesztése a 90-es évek második felében kezdődött meg, köszönhetôen a felfedezett szupernóvák egyre nagyobb számának, a természetükről rendelkezésre álló ismeretek bővülésének és a gyorsan fejlôdő számítástechnikának, amely lehetôvé tette összetett atmoszféramodellek számolását. Az EPM rendkívül nagy előnye, hogy - az Ia SN-k esetében használt módszerekkel ellentétben - nincs szükség ismert távolságú objektumok felhasználásával történő kalibrációra, tehát a többi távolságmérési eljárástól független eredményt szolgáltat.

Az EPM olyan SN-k esetében használható, amelyeket vastag hidrogénburok vesz körül. A burok nagy része a robbanást követô időszakban átlátszatlan, mivel a hidrogén nagy része ionizált állapotban van. Az atmoszférában azt a réteget, ameddig a burok kívülrôl nézve átlátszó, fotoszférának nevezzük. A fotoszféra helyzetét az atmoszférában alapvetôen két tényező befolyásolja. A kívülről befelé haladó rekombinációs hullámnak köszönhetôen a burok külső rétegei átlátszóvá válnak, egyre mélyebbre látunk bele az atmoszférába. Eközben viszont a teljes burok nagy sebességgel tágul. A két effektusnak köszönhetôen a fotoszféra szerepét a plató fázis során mindig más és más réteg tölti be, a fotoszféra sugara pedig a plató fázis elsô felében egyre lassuló mértékben növekszik, majd ahogy a rekombinációs hullám eléri a mélyebb rétegeket, a fotoszféra mérete csökkenni kezd. A táguló fotoszféra módszert (ahogy az elnevezése is sugallja) az első időszakban alkalmazhatjuk.

Az EPM használata során a távolságot a fotoszféra valódi és a látszó méretének összehasonlításával kapjuk meg. E kettő meghatározásához viszont néhány alapfeltevéssel kell élnünk. Ezek a következők:

- a ledobódó burok gömbszimmetrikus,

- a burok homológ módon tágul és

- a fotoszféra közelítőleg feketetest-sugárzó.

A gömbszimmetria teljesülése a spektropolarimetria módszereivel vizsgálható. Ugyan az ilyen módon eddig tanulmányozott II-P szupernóvák száma még nem túl nagy, az eredmények azt mutatják, hogy ezek a plató fázis első felében eléggé (bár nem teljes mértékben) gömbszimmetrikusnak tekinthetők (pl. Wang \& Wheeler, 2008). Leonard és mtsai (2001) az SN 1999em-et vizsgálva az találták, hogy a polarizáció a plató fázis elején kismértékú, annak második felében pedig némileg növekszik. Hasonlóan, az SN 2004dj vizsgálatakor Leonard és mtsai (2006) mérései azt mutatták, hogy a robbanás utáni elsô 90 napban a polarizáció mértéke nagyon kicsi volt, majd ezt követôen ugrásszerúen megnôtt. A jelenséget azzal magyarázták, hogy a robbanás ugyan aszimmetrikus, viszont a II-P SN-k esetében a vastag, gömszimmetrikus hidrogénburok ezt az aszimmetriát elfedi. Amikor a burok a hidrogén rekombinációjának köszönhetően kellően átlátszóvá válik, akkor tudjuk az aszimmetrikus belsố részeket is észlelni. Ezt támasztja alá az a tény is, hogy azon szupernóvák esetében, amelyek már a robbanás előtt elvesztették a hidrogénburok nagy részét (Ib/c SN-k, 1.4.2 fej.), már egészen korai fázisban jelentős polarizációt mértek (Wang \& Wheeler, 2008).

Modellszámítások szerint (pl. Utrobin, 2007) kb. 3-11 nappal a robbanás bekövetkezte után a ledobóbott burok szabadon, homológ módon tágul, azaz egy adott réteg tágulási sebessége arányos a magtól való távolságával. A gömbszimmetriából és a homológ tágulásból 
következik, hogy a robbanás után $\Delta t$ idő elteltével egy adott réteg sugara:

$$
R=v \cdot \Delta t+R_{0}
$$

ahol $v$ a réteg tágulási sebessége, $R_{0}$ pedig a réteg sugara a homológ tágulás kezdetekor, mely néhány nap után $R$ mellett elhanyagolhatóan kicsi.

A látszó szögméret definíció szerint

$$
\theta=\frac{R}{D}
$$

alakban írható fel, ahol $D$ az SN távolsága. A (2.2) és (2.3) egyenleteket felhasználva pedig az alábbi alakot kaphatjuk:

$$
t=D \cdot \frac{\theta}{v}+t_{0}
$$

Azaz, ha több $t$ időpontban meghatározzuk a szögméretet és a tágulási sebességet, és ezek hányadosát ábrázoljuk $t$ függvényében, akkor a pontokra egy olyan egyenes illeszthetô, amelynek a meredeksége megadja a távolságot, y tengellyel való metszéspontja pedig a robbanás időpontját.

A távolság meghatározásához tehát a szupernóva látszó méretének és a fotoszféra tágulási sebességének ismeretére van szükségünk. Utóbbi probléma részletes tárgyalása a 2.2.2 fejezetben található, míg a szögméret meghatározására használható módszereket a következő rész tartalmazza.

\subsubsection{A látszó szögméret meghatározása}

A látszó méret kiszámításakor kerül elố az EPM használatához szükséges, korábban már említett harmadik alapfeltevés, miszerint a fotoszféra közelítooleg fekete testként sugároz. Mint ismert, a fotoszféra az atmoszférában az a speciális réteg, ameddig a burok kívülről nézve átlátszó. A feketetest-sugárzás létrejöttéhez a fotonok valódi abszorpciója szükséges. Ez viszont nem a fotoszférában, hanem valamivel alatta, az ún. „termalizációs mélységben" történik $\left(R_{\text {term }}\right)$. Eközött és a fotoszféra $\left(R_{\mathrm{f}}\right)$ között a hidrogén nagyfokú ionizációjának köszönhetően sok szabad elektron található, így itt a fotonok ezeken való szóródása, a Thomson-szórás dominál. A Thomson-szórás hatáskeresztmetszete viszont független a hullámhossztól, tehát a $R_{\text {term }}$ és a fotoszféra közötti rétegben a feketetest-sugárzásnak csak az abszolút értéke, a fluxus nagysága változik.

Ennek figyelembevételével a szupernóva fotoszférájának egy adott $\lambda$ hullámhosszon mért fluxusára $\left(f_{\lambda}\right)$ felírható:

$$
4 \pi D^{2} f_{\lambda}=4 \pi R^{2} \pi \zeta_{\lambda}^{2}(T) B_{\lambda}(T)
$$

ahol $D$ az objektum távolsága, $R$ a sugara (2.2 egyenlet), $B_{\lambda}(T)$ a Planck-függvény, $T$ a hőmérséklet, $\zeta_{\lambda}(T)$ pedig egy korrekciós faktor, amellyel a sugárzásnak a Planck-függvénytôl való eltérését kompenzáljuk (ld. részletesen 2.2.3 fej.). Felhasználva a (2.3) egyenletet, a szögsugár a következőképpen számítható ki:

$$
\theta=\sqrt{\frac{f_{\lambda}}{\pi \zeta_{\lambda}^{2}(T) B_{\lambda}(T)}}
$$


Ha az EPM-et nagy vöröseltolódású, távoli SN-kra szeretnénk alkalmazni, akkor a fenti egyenleteket némileg módosítani kell (Schmidt és mtsai, 1994a). Egyrész a (2.2) egyenletben figyelembe kell venni az idődilatációt:

$$
\frac{t}{1+z}=D \cdot \frac{\theta}{v}+\frac{t_{0}}{1+z}
$$

Másrészt számolni kell azzal, hogy a (2.5) egyenletben a luminozitás-távolság $\left(D_{L}\right)$ szerepel, míg a (2.2) egyenletben a szögátméró-távolság $\left(D_{A}\right)$. A kettő közötti kapcsolat $D_{L}=(1+$ $z)^{2} D_{A}$ alakban írható fel. Ennek megfelelően a (2.6) egyenlet a következőképpen módosul:

$$
\theta=\sqrt{\frac{f_{\lambda}(1+z)}{\pi \zeta_{\lambda^{\prime}}^{2}(T) B_{\lambda^{\prime}}(T)}}
$$

ahol a $\lambda^{\prime}=\lambda /(1+z)$.

Az EPM gyakorlatba való átültetése során több megközelítés használható. A leggyakrabban használt módszer a különbözô szúrôkkel mért magnitúdókkal számol (Hamuy \& Pinto, 2002). Egy objektum $\bar{\lambda}$ központi hullámhosszú szúrôvel észlelt fényessége magnitúdóban:

$$
m_{\bar{\lambda}}=-2,5 \cdot \log \int_{0}^{\infty} \phi_{\lambda} f_{\lambda} d \lambda
$$

ahol $\phi_{\lambda}$ a szûrố átviteli függvénye, $f_{\lambda}$ pedig az észlelt fluxus. A 2.5 egyenlet felhasználásával felírható, hogy

$$
m_{\bar{\lambda}}=-5 \log \zeta-5 \log \theta+b_{\bar{\lambda}}
$$

ahol

$$
b_{\bar{\lambda}}=-2,5 \cdot \log \int_{0}^{\infty} \phi_{\lambda} \pi B_{\lambda}(T) d \lambda+C_{\lambda}
$$

a feketetest-sugárzás szintetikus magnitúdója adott szúrôn át, $C_{\lambda}$ egy integrálási állandó. Hamuy (2001) meghatározta $b_{\lambda}$ értékét a $B V R I Z J H K$ szűrőkkel, és minden esetben egy

$$
b_{\bar{\lambda}}(T)=\sum_{i=0}^{i_{\max }} c_{i}\left(\frac{10^{4} K}{T}\right)^{i}
$$

alakú polinommal illesztette az eredményeket. A $B V R I$ szúrókre vonatkozó koefficienseket (melyek felhasználásra kerülnek késôbb ebben a dolgozatban), a 2.1. táblázat tartalmazza.

A (2.10) egyenlet alapján definiálható a következő mennyiség:

$$
\chi^{2}=\sum_{\bar{\lambda} \varepsilon S} \frac{\left(m_{\bar{\lambda}}+5 \log \left(\theta \zeta_{S}\right)-b_{\bar{\lambda}}(T)\right)^{2}}{\sigma_{m}^{2}},
$$

ahol $\mathrm{S}$ a különböző szúrốkombinációkat jelenti $(S=\{B V I\},\{B V\},\{V I\},\{B V R I\}), \sigma_{m}$ pedig a fotometriai mérések hibája. Ezen $\chi^{2}$ mennyiség minimumának megkeresésével határozhatjuk meg egyidejúleg $\theta$ szögméret és $T$ hőmérséklet értékét.

Egy másik lehetséges variáció, amikor az egyes szűrőkkel mért magnitúdók helyett a bolometrikus fluxust használjuk. A (2.6) egyenletet a teljes hullámhossztartományra integrálva kapjuk a

$$
\theta=\sqrt{\frac{f_{\mathrm{bol}}}{\zeta^{2}(T) \sigma T_{\mathrm{eff}}^{4}}}
$$


2.1. táblázat. A szintetikus magnitúdó meghatározásához használt összefüggésben (2.12. egyenlet) szereplő koefficiensek (Hamuy, 2001).

\begin{tabular}{ccccccc}
\hline $\mathrm{i}$ & 0 & 1 & 2 & 3 & 4 & 5 \\
\hline$c_{i}(B)$ & $-45,144$ & 7,159 & $-4,301$ & 2,639 & $-0,811$ & 0,098 \\
$c_{i}(V)$ & $-44,766$ & 6,793 & $-4,523$ & 2,695 & $-0,809$ & 0,096 \\
$c_{i}(R)$ & $-44,597$ & 6,628 & $-4,693$ & 2,770 & $-0,831$ & 0,099 \\
$c_{i}(I)$ & $-44,345$ & 6,347 & $-4,732$ & 2,739 & $-0,811$ & 0,096 \\
\hline
\end{tabular}

összefüggést, ahol $f_{\text {bol }}$ a bolometrikus fluxus, $\sigma$ pedig a Stefan-Boltzmann-állandó. A hőmérséklet meghatározása ekkor úgy lehetséges, hogy a mért magnitúdókat fluxussá konvertáljuk, és ezekre egy feketetest-görbét illesztünk.

\subsubsection{A tágulási sebesség mérése}

A tágulási sebességet a felvett optikai spektrumból lehet meghatározni. A leggyakrabban használt módszer a P Cygni vonalprofil abszorpciós minimuma Doppler-eltolódásának mérése bizonyos spektrumvonalak esetében. Ezenkívül történtek próbálkozások a - csillagok esetében gyakran és sikeresen alkalmazott - keresztkorrelációs technikával is. A legpontosabb, ám jelentős számítási kapacitást igénylő módszernek a teljes spektrum NLTE modellezése tûnik.

Az alábbiakban ezt a három módszert ismertetem részletesebben, és megvizsgálom alkalmazásuk előnyeit és hátrányait.

\section{A Doppler-sebesség}

A P Cygni vonalprofil azon objektumok spektrumvonalaira jellemző, ahol a sugárzás forrását egy vastag, táguló gázfelhő veszi körül. A vonalprofil két részből áll: egy kiszélesedett emissziós részből, amelynek a maximuma a spektrumvonal laboratóriumi hullámhosszánál van, valamint egy kékeltolódott abszorpciós komponensből (2.2. ábra). Az emissziós részt azok a fotonok alkotják, amelyek az atmoszféra különböző részeiről „,beszóródnak” a látóirányunkba. Ezek eltérố mértékben kék- vagy vöröseltolódottak, emiatt az emissziós vonalkomponens jelentôsen kiszélesedett. Az abszorpciós rész a fotonoknak a látóirányból történő kiszóródása okozza. Mivel a kiszóródás a megfigyelő és a fotoszféra közötti tartományban zajlik, ez a komponens kékeltolódott lesz. Az abszorpció minimumhelyének Doppler-eltolódása a fotoszféra tágulási sebességének felel meg (Kasen és mtsai, 2002; Branch és mtsai, 2003; ld. még a 3.2.1 fej.-et).

Elvileg tehát a vonalminimum helyéből a fotoszféra sebessége meghatározható. A gyakorlatban viszont ehhez optikailag vékony vonalak $(\tau<1)$ szükségesek, ugyanis ezek esetében történik a szóródás a fotoszféra közelében. Azt, hogy mely vonal tekinthetố ilyennek, többek között Hatano és mtsai (1999) vizsgálták különböző összetételú és hőmérsékletú $\mathrm{SN}$-atmoszférák esetében. A sebesség mérésekor problémát jelent, hogy ezek az optikailag vékony vonalak gyengék, ezért a minimumhely hullámhosszának kimérése meglehetősen 

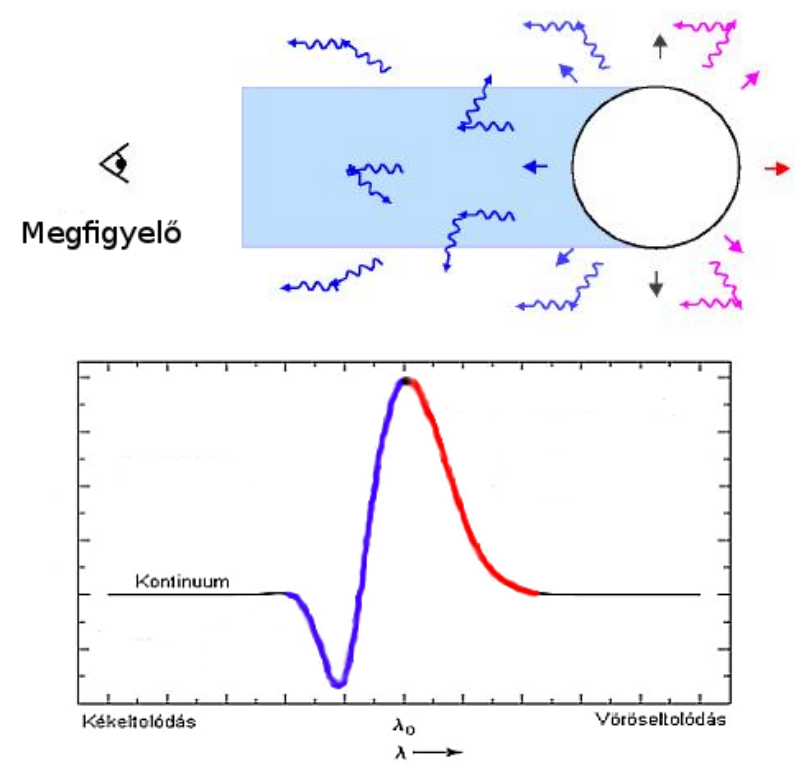

2.2. ábra. A P Cygni vonalprofil létrejöttének vázlatos szemléltetése

pontatlan. Ehhez ráadásul még hozzájárul a különböző spektrumvonalak egymásra rakódása is.

A Doppler-eltolódás mérésére leggyakrabban az Fe II vonalait használják, amelyek optikailag vékonynak tekinthetôk a plató fázis elsô felében (lásd pl. Hatano és mtsai 2. ábráját). Leonard és mtsai (2002) azonban jóval gyengébb vonalak minimumát megmérve azt találták, hogy azok kb. 10\%-kal kisebb sebességre utalnak, mint amit az Fe II 4924, 5018 és 5169 Å hullámhosszú vonalakból számoltak. Ez felveti annak kérdését, hogy ezek a vasvonalak ténylegesen mennyire tükrözik a fotoszféra tágulási sebességét.

Dessart \& Hillier (2005b) munkájuk során a CMFGEN nevú NLTE kódot felhasználva szupernóva-spektrumokat modelleztek. Megmérték a létrehozott modellspektrumok bizonyos vonalai minimumának Doppler-eltolódását ( $\left.v_{\mathrm{abs}}\right)$, és az így kapott sebességet összevetették azzal a fotoszferikus sebességgel, amelyet a modell bemeneti paramétereként megadtak. Ilyen módon megmutatták, hogy a $v_{\text {abs }}$ értékei alul- és felül is becsülhetik a tényleges fotoszferikus sebességet, a ledobódó burokban uralkodó fizikai körülményektôl függően.

A tágulási sebesség távolságmérésben való használata során egy másik probléma is felmerül. Ugyanis míg az Fe II 5169 Å vonal többnyire könnyen azonosítható és mérhető a robbanás utáni kb. 20. naptól, az ennél korábbi időpontokban ez először nincs, majd csak nagyon gyengén van jelen a spektrumban. A korai fázisban a II-es típusú SN-k optikai spektruma csak a H I Balmer-sorozatát, illetve egyes esetekben a He I vonalait tartalmazzák, amelyek nem optikailag vékonyak. Ezekben az esetekben, valamint olyankor, amikor a rossz jel/zaj viszony miatt az Fe II $5169 \AA$ is nehezen azonosítható, általában a H $\beta$ vonalat használják a sebesség becslésére. Annak ellenére, hogy Dessart \& Hillier (2005b) megmutatták, hogy az ennek a vonalnak a Doppler-eltolódásából mért sebesség gyengébben korrelál a fotoszferikus sebességgel, mint a $v_{\mathrm{Fe}}$, már több kísérlet is történt az ezek közti, 

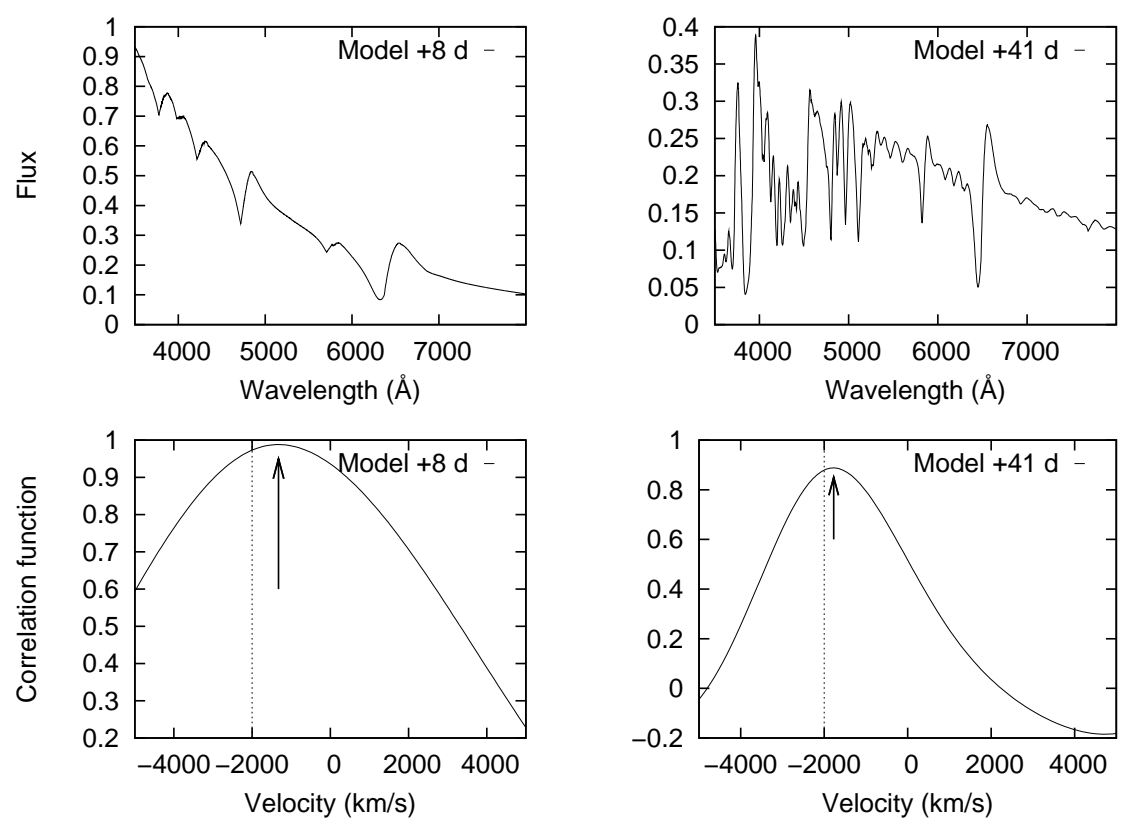

2.3. ábra. A II-P SN-kra korai fázisban (bal felső kép) és a plató közepére (jobb felsô kép) jellemző modellspektrum. Az alsó ábrákon a kapott CCF látható, melyeken a szaggatott vonal a keresztkorreláltatott két spektrum közti valódi, $\Delta v_{\text {fot }}$ sebességkülönbség helyét jelöli, míg a nyíl a CCF maximumának helyét mutatja (Takáts \& Vinkó, 2012).

illetve a $v_{\mathrm{Fe}}$ és $\mathrm{H} \beta$ Doppler-sebessége $\left(v_{\mathrm{H} \beta}\right)$ közti összefüggések megállapítására. Nugent és mtsai (2006) például azt találták, hogy a $v_{\mathrm{H} \beta} / v_{\mathrm{Fe}}$ arány konstans, $(\sim 1,4)$, ha $v_{\mathrm{H} \beta}<6000$ $\mathrm{kms}^{-1}$, és lineárisan csökken, ha ennél nagyobb. Hasonlóan, Poznanski és mtsai (2010) eredményei azt mutatták, hogy a két sebesség aránya a robbanás utáni 5. és 40. nap között lineárisan változik.

\section{Keresztkorreláció}

Figyelembe véve $v_{\text {abs }}$ mérésének nehézségeit, és azt, hogy ennek értéke nem adja vissza pontosan a fotoszferikus sebességet, más módszerekkel is történtek próbálkozások. Az egyik ilyen a csillagok esetében gyakran és nagy pontossággal alkalmazott keresztkorrelációs módszer. Ennek során a teljes spektrumra határozzák meg a vonalak Doppler-eltolódását úgy, hogy kiszámolják az ún keresztkorrelációs függvényt (cross-correlation function, CCF) a vizsgált és egy ismert sebességú összehasonlító spektrum között:

$$
C C F(y)=\int_{-\infty}^{\infty} f(x) \cdot g(x-y) d x
$$

A CCF maximumának helye megadja, hogy mekkora mértékben kell eltolni az egyik spektrumot a másikhoz képest ahhoz, hogy a kettő a lehető legjobban átfedjen.

Hamuy és mtsai (2001) és Hamuy \& Pinto (2002) a keresztkorrelációhoz az Eastman és mtsai (1996) által készített spektrummodelleket használták fel és azt találták, hogy kereszt- 
korrelációval kapott sebesség alulbecsüli a modellek számolásakor bemeneti paraméterként megadott fotoszferikus sebességet.

Poznanski és mtsai (2009) a keresztkorrelációval abból a célból próbálkoztak, hogy zajos spektrumok esetében tudják az Fe II 5169 Å vonal Doppler-sebességét $\left(v_{\mathrm{Fe}}\right)$ meghatározni, ilyen spektrumokban ugyanis a vonalminimumot csak rendkívül pontatlanul lehet megmérni. A keresztkorrelációhoz az SNID (SN identification code ${ }^{12}$, Blondin \& Tonry, 2007) nevú, a SN-k spektrum alapján történő besorolásához készített program adatbázisában található, jó jel/zaj viszonyú spektrumokat használták, amelyek esetében a $v_{\mathrm{Fe}}$ elég pontosan mérhetô. A keresztkorrelációt a $4500-5500 \AA$ közötti hullámhossztartományra végezték, egyidejúleg több összehasonlító spektrum felhasználásával, és a kapott sebességeket átlagolták. 2011es cikkükben ezt a módszert kiterjesztették korai, a robbanást követő 40. nap előtt felvett spektrumokra, amelyek esetében a vasvonalak még vagy nem jelentek meg, vagy nagyon gyengék voltak. A keresztkorrelációval ekkor a $\mathrm{H} \beta$ sebességét mérték meg, és az előző részben említett, a $v_{\mathrm{H} \beta}$ és a $v_{\mathrm{Fe}}$ között talált lineáris összefüggés segítségével számították ki a $v_{\mathrm{Fe}}$ értékét. Arra a következtetésre jutottak, hogy ez az eljárás zajos spektrumok esetén valamivel pontosabbá teszi $v_{\mathrm{Fe}}$ mérését.

A keresztkorreláció használata a P Cygni vonalprofilt mutató spektrumvonalak esetében azonban nem teljesen megalapozott. Ugyanis míg a profil abszorpciós része a sebesség növelésével egyre inkább eltolódik a rövidebb hullámhosszak felé, addig az emissziós komponens továbbra is a laboratóriumi hullámhosszon, nulla sebesség környékén marad. Ezáltal akármennyire is hasonló a keresztkorreláltatott két spektrum, az eredményként kapott sebesség alulbecsüli a valódit.

Ennek szemléltetésére a következő tesztet hajtottuk végre (Takáts \& Vinkó, 2012). A szupernóvaspektrumot modellező SYNOW ${ }^{13}$ nevú programmal (Fisher, 1999) készítettünk két olyan SN spektrumot, amelyek minden tekintetben azonosak voltak, kivéve a fotoszferikus sebességüket, amelyek különbsége $\Delta v_{\text {fot }}=2000 \mathrm{kms}^{-1}$ volt. Ezután a két spektrum 45005500 Å közötti hullámhossztartományát keresztkorreláltattuk az IRAF fxcor nevú task-ját használva. Ez a régió a $\mathrm{H} \beta$ vonalat és több vasvonalat is tartalmazza. Ezt a kísérletet kétféle modellel is elvégeztük: egy korai fázisban lévő és egy, a plató közepére jellemző spektrumot is vizsgáltunk (2.3 ábra). Az találtuk, hogy a későbbi spektrum esetében a keresztkorreláció kb. $v_{\text {rel }}=200 \mathrm{kms}^{-1}$-mal kisebb sebességet eredményezett, mint $\Delta v_{\text {fot }}$, míg a korai spektrum esetében ez $\mathrm{kb}$. $v_{\text {rel }}=700 \mathrm{kms}^{-1}$ lett (2.3. ábra). A két eset közötti különbség oka, hogy a korai spektrum az adott hullámhossztartományban csak a széles $\mathrm{H} \beta$ vonalat tartalmazta, míg a későbbi spektrumban több, jóval keskenyebb vonal is jelen van, amelyek miatt a keresztkorreláció is kisebb hibával terhelt.

A fentiekből tehát kitûnik, hogy a keresztkorreláció használata elsősorban akkor lehet indokolt, ha nagyon zajos spektrumok esetében kell sebességet becsülni, de figyelembe kell venni, hogy használata jelentős hibával terhelt, főként korai spektrumok esetében.

\section{Sebességmérés NLTE spektrummodellekkel}

A fotoszferikus sebesség megállapítására talán a legpontosabb eljárás az észlelt spektrum teljes modellezése nem lokális termodinamikai egyensúlyt (NLTE) alkalmazó számításokkal.

\footnotetext{
${ }^{12}$ http://www.oamp.fr/people/blondin/software/snid/index.html

13 http://www.nhn.ou.edu/ parrent/synow.html
} 
2.2. táblázat. Eastman és mtsai (1996) (E96) és Dessart \& Hillier (2005b) (D05) modellszámításai alapján kapott, a (2.16) egyenletben szereplő $a_{S, j}$ koefficiensek értékei különböző szűrőkombinációk esetén.

\begin{tabular}{lcccccccc}
\hline \hline & \multicolumn{4}{c}{ E96 } & \multicolumn{4}{c}{ D05 } \\
$\mathrm{j}$ & $\{\mathrm{BV}\}$ & $\{\mathrm{BVI}\}$ & $\{\mathrm{VI}\}$ & $\{\mathrm{JHK}\}$ & $\{\mathrm{BV}\}$ & $\{\mathrm{BVI}\}$ & $\{\mathrm{VI}\}$ & $\{\mathrm{JHK}\}^{a}$ \\
\hline 0 & 0,7557 & 0,7336 & 0,7013 & 1,4787 & 0,4719 & 0,6324 & 0,8166 & 0,1079 \\
1 & $-0,8997$ & $-0,6942$ & $-0,5304$ & $-0,4799$ & $-0,2540$ & $-0,3837$ & $-0,6289$ & 1,1237 \\
2 & 0,5199 & 0,3740 & 0,2646 & 0,0000 & 0,3263 & 0,2843 & 0,3385 & 0,0000 \\
\hline & \multicolumn{3}{c}{ E Ebben az esetben a (2.16) egyenlet helyett a $\zeta_{J H K}=\sum_{j} a_{j}\left(\frac{T_{S}}{10^{4} K}\right)^{j}$ alakú polinomot } \\
& illesztett Dessart \& Hillier (2005b).
\end{tabular}

Ilyen vizsgálatokak végeztek például Baron és mtsai (2004) a PHOENIX nevú kóddal, valamint Dessart \& Hillier (2006) és Dessart és mtsai (2008) a CMFGEN nevú programmal. Alkalmazásuk során a fotoszférát általában az a réteg jelenti, ahol az optikai mélység 1 vagy 2/3 (Dessart \& Hillier, 2005a), a fotoszferikus sebesség pedig az ehhez a réteghez tartozó $r_{\text {fot }}$ sugárból számolható ki, homológ tágulást feltételezve.

Habár ezzel a módszerrel határozható meg a legpontosabban és a legkövetkezetesebb módon a fotoszferikus sebesség, használata mégsem hatékony, ugyanis egyetlen ilyen NLTE modell elkészítése is jelentős számítási kapacitás igényel. Emiatt nagyszámú spektrumra történő alkalmazása ilyen célból túlságosan időigényes.

Hasonló sebességmérést úgy is végezhetünk, ha modellezésre egy jóval egyszerúbb programot, például a SYNOW nevú, kifejezetten szupernóvák spektrumának modellezéséhez készült, lokális termodinamikai egyensúly (LTE) közelítést használó parametrizált kódot alkalmazzuk (3.2. fej.).

\subsubsection{Atmoszféramodellek és a korrekciós faktor}

A táguló fotoszféra módszer alkalmazásának egyik kritikus pontja a $\zeta$ korrekciós faktor meghatározása. Ez a mennyiség azt írja le, hogy a megfigyelt spektrális energiaeloszlás milyen mértékben tér el a feketetest-sugárzásétól. A korrekciós faktor két részből áll össze. Az egyik a termalizációs mélység és a fotoszféra között fellépő szórás, amely a fluxus nagyságát módosítja. A másik részét pedig a megjelenő spektrumvonalak okozzák, amelyek eltorzítják a feketetest-görbét. Ez utóbbi hatása korai fázisban nem jelentôs, csak a fémvonalak megjelenése után nő meg a szerepe. A korrekciós faktor kiszámításához részletes atmoszféramodellek készítése szükséges.

Ilyen jellegú vizsgálatokat elsôként Eastman és mtsai (1996) végeztek. Egy NLTE hidrodinamikai kód használatával nagyszámú spektrummodellt hoztak létre a szupernóva fejlődésének különböző fázisaiban, a fizikai paramétereket széles tartományon változtatva. A létrehozott modellek bemeneti fizikai paramétereit használva, a (2.13) összefüggés minimalizálásával meghatározták $\zeta_{S}$ és $T_{S}$ értékét. A számításokat több szürőkombinációra is elvégezték, hiszen mind a korrekciós faktor, mind a színhőmérséklet meghatározását befolyásolja, hogy mely hullámhosszon végezzük a mérést. A korrekciós faktor értéke szoro- 

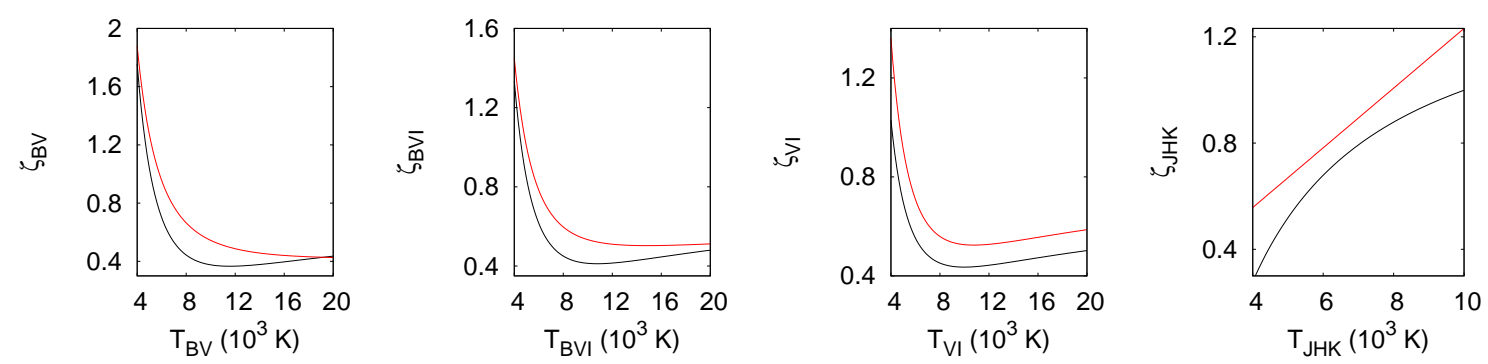

2.4. ábra. A Eastman és mtsai (1996) (fekete) és a Dessart \& Hillier (2005b) (piros) által számolt $\zeta$ korrekciós faktorok összehasonlítása különböző szúrôkombinációk esetén.

san összefügg a színhőmérséklettel, a kettő közti kapcsolat egy

$$
\zeta_{S}=\sum_{j=0}^{j_{\max }} a_{S, j}\left(\frac{10^{4} K}{T_{S}}\right)
$$

alakú függvénnyel írható le, ahol $S$ a $\{B V\},\{B V I\},\{V I\},\{J H K\}$ szürőkombinációk egyikét jelenti. Az $a_{S, j}$ együtthatók - Hamuy (2001) által kissé pontosított - értékei a 2.2. táblázatban megtalálhatóak.

Dessart \& Hillier (2005b) a CMFGEN nevú NLTE atmoszféramodellezô programmal készített modellspektrumok (Dessart \& Hillier, 2005a) felhasználásával ismételték meg a számításokat. Ezek a modellek elsősorban az SN 1987A és az SN 1999em észlelt spektrumain alapultak. Segítségükkel az Eastman és mtsai (1996) által használt módszerrel megegyező módon, ugyanazokra a szűrőkombinációkra számították ki $\zeta_{S}$ értékeit, és a (2.16) polinomot illesztették ezekre. A kapott együtthatókat a 2.2 táblázat tartalmazza.

A két munka jelentősen eltérő eredményeket szolgáltatott, ezek összehasonlítását a 2.4. ábra mutatja. A különbségre Dessart \& Hillier (2005b) nem tudott pontos magyarázatot adni, azt valószínúsítették, hogy ez a modellek számításának módjában keresendő. A két csoport által meghatározott $\zeta$ különbsége az EPM alkalmazása során a távolságban 10 20\%-os eltéréshez vezet. Ez jól megmutatható az SN 1999em példáján keresztül. Ennek a rendkívül jól észlelt és alaposan megvizsgált szupernóvának a távolságát több csoport is megmérte. Az Eastman és mtsai (1996) által meghatározott korrekciós faktorokkal $\left(\zeta_{\mathrm{E} 96)}\right.$ az EPM-mel kapott távolság $D \sim 8-9$ Mpc körüli (Leonard és mtsai, 2002; Elmhamdi és mtsai, 2003; Jones és mtsai, 2009). Leonard és mtsai (2003) ellenôrzésképpen a szupernóva galaxisában található cefeida változócsillagok segítségével is végeztek távolságmérést, és valamivel nagyobb, $D=11,7 \pm 1,0 \mathrm{Mpc}$ értéket kaptak. Dessart \& Hillier (2006) korábban publikált modelljeik és korrekciós faktoraik felhasználásával a távolságot $D=11,5 \pm 1,0$ Mpc-nek határozták meg, ami nagyon jól egyezik a cefeidák segítségével kapottakkal és jelentősen nagyobb, mint a $\zeta_{\mathrm{E} 96}$ használatával mért távolságok.

\subsubsection{Fớbb nehézségek és hibaforrások}

Az EPM alkalmazása során több nehézség is felmerül, amelyek befolyásolhatják a módszer pontosságát, és amelyekre nagy figyelmet kell fordítani. Ahogy ismereteink bővülnek, 


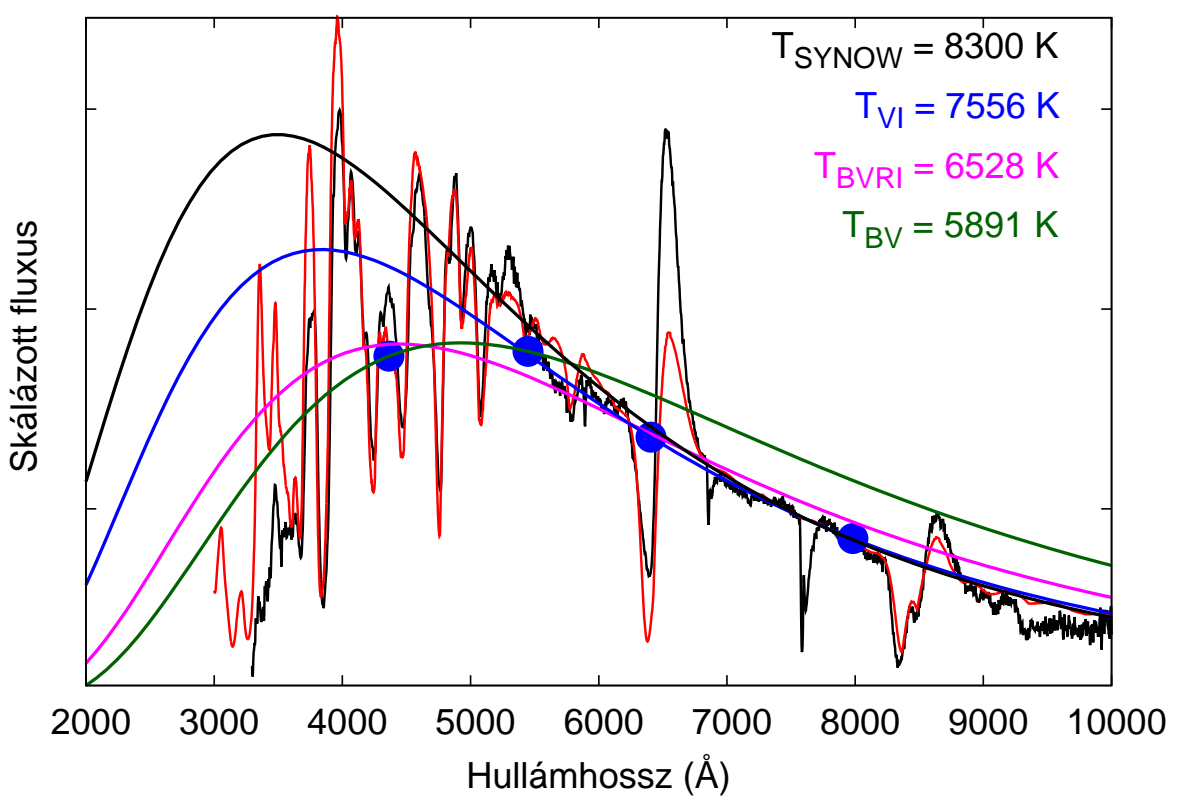

2.5. ábra. Példa arra, hogy a hőmérséklet meghatározását befolyásolja az, hogy mely szürőkombinációt használjuk. Az SN 1999em robbanás után 24 nappal észlelt spektrumának (fekete) elkészítettem a modelljét a SYNOW-val (piros, $T_{\text {SYNOW }}$ ). Az ugyanezen a napon készült $B V R I$ fotometriai mérések segítségével (kék pöttyök) meghatároztam a hőmérsékletet különböző szúrốkombinációk esetén $\left(T_{B V R I}, T_{B V}\right.$ és $\left.T_{V I}\right)$.

az ezekből származó bizonytalanság egyre inkább csökkenthető, és a módszer egyre távolabbi objektumokra lesz alkalmazható, egyre megbízhatóbban.

Elméletileg az EPM alkalmazásához két, különböző időpontban felvett adat ugyan elegendő, a véletlen és szisztematikus hibák csökkentése érdekében viszont minél több, jó minőségû adatra van szükség az plató fázis elsô feléből. Ennek összegyưjtése önmagában is sok nehézséggel jár, ráadásul sok esetben nem lehetséges egyidejúleg mind fotometriai, mind spektroszkópiai észleléseket is végezni, ezért gyakran kell egyiket a másik időpontjaira interpolálni.

A mért fényeséget korrigálni kell a csillagközi por által okozott extinkcióra és vörösödésre. A vörösödés mértékének meghatározása nem egyszerú (ld. 3.1.1 fej.). Szerencsére ennek pontosságára az EPM csak kismértékben érzékeny. Eastman és mtsai (1996), valamint Leonard és mtsai (2002) kimutatták, hogy 1 magnitúdónyi hiba az $A_{V}$ értékében kb. $8 \%$ hibát eredményez a távolság meghatározásában.

Bizonytalan tényező az EPM használatakor, hogy a korrekciós faktor meghatározása modellszámításokra épül, és hogy ilyen tanulmány még csak kettő született, amelyek ráadásul inkonzisztens eredményt szolgáltattak.

Az EPM használata során fontos paraméter a fotoszféra hőmérséklete. A spektrumvonalak jelenléte miatt az SN-k spektruma nem illeszthető egyetlen feketetest-görbével, ezért a hőmérséklet meghatározása nem triviális feladat. Amennyiben a (2.13) összefüggés minimalizálását használjuk a szögméret kiszámítására, akkor a $\theta$-val együtt a hőmérsékletet is 
megkapjuk. Viszont ennek értéke függ a szűrőkombináció megválasztásától. Ha a szögméret meghatározásához a bolometrikus fluxust használjuk (2.14 egyenlet), akkor a $T$ értékét külön kell megmérnünk. Ez olyan módon lehetséges, hogy az adott időpontban mért magnitúdókat fluxussá konvertáljuk, és rájuk egy feketetest-görbét illesztünk. Ekkor is kérdéses viszont, hogy mely szűrővel mért fényességeket használjuk. A $B$ szúrő hullámhossztartományán nagyon sok erôs fémvonal található, míg az $R$ szûrố tartományába esik a $H \alpha$ vonal. Emiatt a kapott színhőmérséklet más és más lesz különbözô a különböző szúrőkombinációk esetén (2.5. ábra).

A tágulási sebesség mérésével kapcsolatos nehézségekrôl a 2.2.2 részben már volt szó, és ahogy ott is említettük, egy újabb, a SYNOW programot használó módszer részletes ismeretetésérôl és elemzéséről a további fejezetekben lesz szó.

\subsubsection{Az EPM variációi}

Az előzőekben említett nehézségek egy részének kiküszöbölésére fejlesztették ki az EPM olyan változatait, amelyeknél az észlelt spektrumokat modellezik NLTE atmoszféramodellek létrehozásával.

Az egyik ilyen módszer az ún. spektrumillesztéses táguló fotoszféra módszert (spectralfitting expanding photoshere method, SEAM; Baron és mtsai, 1995, 1996; Mitchell és mtsai, 2002; Baron és mtsai 2004) mely a PHOENIX nevú kóddal (Hauschildt \& Baron, 1999) készített modellspektrumokra alkalmaztak először. Az észlelt spektrumokra illesztett modellek az SN luminozitását is megadják, így ezek spektrofotometriájával az abszolút magnitúdók megmérhetôk. Ezeket pedig az észlelt magnitúdókkal összehasonlítva megkapjuk az SN távolságát. Nincs szükség feketetest-közelítésre, a korrekciós faktorok és a színhőmérséklet számítására. Viszont ez a módszer nagyon nagy számítási kapacitást igényel, így a mai napig csak kisszámú SN esetében alkalmazták.

Dessart \& Hillier (2006) az EPM egy olyan variációját használták, amelynek során a CMFGEN kóddal készített modellspektrumok felhasználásával határozták meg a korrekciós faktor, a hőmérséklet és a tágulási sebesség értékét, mintegy ötvözve az EPM-et és a SEAMot. Az SN 1999em távolságát ezzel a módszerrel, valamint a (2.13) összefüggés minimalizásával és a Baron és mtsai (2004) által használt SEAM módszerrrel is kiszámították. Azt találták, hogy az ő variációjuk jól visszaadja a szülőgalaxisban lévő cefeidák segítségével kapott távolságot. A SEAM ennél valamivel nagyobb távolságot eredményezett, míg a klasszikusan használt módszerrel kapott eredmények nagy szórást mutattak a használt szúrôkombinációtól és korrekciós faktortól függóen.

\subsection{A II-es típusú SN-k távolsága - a standard(izált) gyer- tya módszer}

A II-P típusú szupernóvák távolságának meghatározására egy új módszert Hamuy \& Pinto (2002) vetett fel. Munkájuk során azt találták, hogy a II-P típusú szupernóvák esetében a plató fázis közepén mérhetô fényesség és tágulási sebesség korrelál. 2002-es cikkükben 17 olyan SN adatait vizsgálták meg, amelyeknek már ismert volt a távolsága. A robbanás utáni 50. napon az Fe II 5169 Å vonal minimumának Doppler-eltolódásából mért sebesség $\left(v_{\mathrm{Fe}}\right)$ 

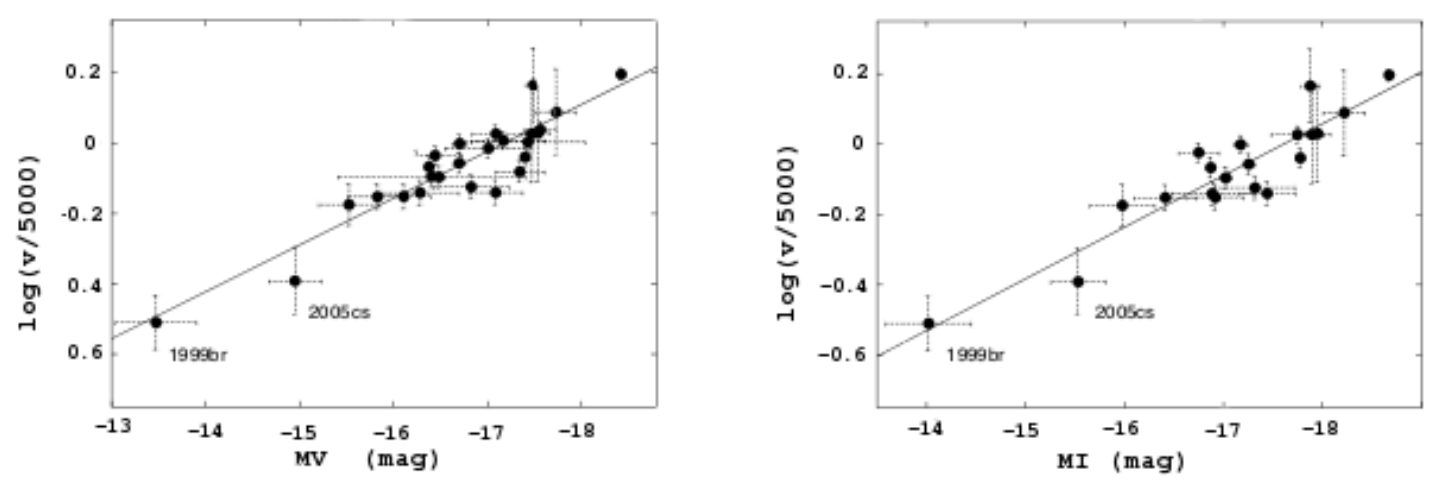

2.6. ábra. A plató közepén mérhető fényesség és tágulási sebesség közti kapcsolat. Látható, hogy a halványabb SN-ket csak az SN 1999br és 2005cs képviseli (Takáts \& Vinkó, 2006).

valamint a $V$ illetve $I$ szúrőn át mért fényesség között az alábbi összefüggéseket találták:

$$
V(50 \mathrm{~d})-A_{V}+a_{V} \log \left(\frac{\nu_{\mathrm{Fe}}(50 \mathrm{~d})}{5000}\right)=5 \log (c z)-b_{V}
$$

illetve

$$
I(50 \mathrm{~d})-A_{I}+a_{I} \log \left(\frac{v_{\mathrm{Fe}}(50 \mathrm{~d})}{5000}\right)=5 \log (c z)-b_{I}
$$

ahol $v_{\mathrm{Fe}}(50 \mathrm{~d}), V(50 \mathrm{~d})$ és $I(50 \mathrm{~d})$ a robbanás utáni 50. napon mért tágulási sebességet és a $V$ illetve $I$ szúrő́n át mért fényeséget jelöli, $A_{V}$ és $A_{I}$ a $V$ illetve $I$ szúrős extinkciós korrekció, $c$ a fénysebesség, $z$ pedig a vöröseltolódás. Az illesztés során a következő paramétereket kapták: $a_{V}=6,504 \pm 0,995, b_{V}=1,294 \pm 0,131, a_{I}=5,820 \pm 0,764$ és $b_{I}=1,797 \pm 0,103$. Az illesztés során az I szűrôs adatok esetében a pontok szórása némileg kisebbnek bizonyult.

A fenti összefüggéseket a későbbiekben többen is finomították, egyre bővítve a használt mintát. Hamuy (2005) már 24 objektum felhasználásával számolta újra az $a$ és $b$ paraméterek értékét.

Ahogy a 2.6 ábrán megfigyelhető, a mintákban a halványabb II-P típusú SN-kat csak egyetlen objektum, az SN 1999br képviselte. Emiatt amikor a szintén alacsonyabb luminozitású SN 2005cs-t vizsgáltam (Takáts \& Vinkó, 2006), ezzel az SN-nel kiegészítettem Hamuy (2005) mintáját, és újrakalibráltam az ott szereplő összefüggéseket. A következő paramétereket kaptam: $a_{V}=6,19 \pm 0,57, b_{V}=1,41 \pm 0,08, a_{I}=5,82 \pm 0,57$ és $b_{I}=$ $1,85 \pm 0,09$.

Nugent és mtsai (2006) a Hamuy (2005) tanulmányában szereplő adatokat használták fel és egészítették ki még hat, távolabbi SN-nel. Ők olyan módon fejlesztették tovább a módszert, hogy a $V$ és $I$ szűrős méréseket nem külön-külön vizsgálták, hanem a $(V-I)$ színindexet használva kombinálták ezeket. A következő összefüggést kapták:

$$
M_{I}(50 \mathrm{~d})=-\alpha \log (v(50 \mathrm{~d}) / 5000)-1,36\left((V-I)-(V-I)_{0}\right)+M_{I, 0},
$$

ahol $M_{I}(50 \mathrm{~d})$ az abszolút fényesség a robbanás utáni 50. napon. Az illesztés során kapott paraméterek a következők: $\alpha=6,69 \pm 0,50, M_{I, 0}=-17,49 \pm 0,08 \operatorname{mag}\left(H_{0}=70 \mathrm{kms}^{-1} \mathrm{Mpc}^{-1}\right.$ felhasználásával), $(V-I)_{0}=0,53 \mathrm{mag}$. 
Poznanski és mtsai (2009) ezt a mintát további 17 szupernóva adataival egészítették ki, ezáltal a kalibrációhoz már 40 SN adatai áltak rendelkezésükre. A használt összefüggést ôk is tovább módosították, a következő egyenletet illesztették az adatokra:

$$
\mathcal{M}_{I}-\alpha \cdot \log \left(v_{\mathrm{Fe}}(50 \mathrm{~d}) / 5000\right)+R_{I}((V-I)-0,53)-m_{I}=-5 \cdot \log \left(H_{0} D\right)
$$

Itt $\mathcal{M}_{I} \equiv M_{I_{0}}-5 \log \left(H_{0}\right)+25$, amelyre a kalibráció során $\left(H_{0}=70 \mathrm{kms}^{-1} \mathrm{Mpc}^{-1}\right.$ értéket használva) $\mathcal{M}_{I}=-1,615 \pm 0,08$ értéket kaptak. Az illesztés során kapott további paraméterek $\alpha=4,4 \pm 0,6$ és $R_{I}=0,8 \pm 0,3$ nagyságúnak adódtak.

Maguire és mtsai (2010a) megvizsgálták, hogy alkalmazható-e az SCM az optikai helyett NIR tartományban végzett mérések esetén. Ehhez 12 SN adatait használták fel, amelyekről $J H K$ szûrôkben készült fotometriai mérések álltak rendelkezésükre. A Poznanski és mtsai (2009) által felállított összefüggést használták (2.20 egyenlet), csak az I szúrôs mérések helyett a $J, H$ és $K$ szúrôvel készülteket vették figyelembe. Azt találták, hogy mindhárom NIR szúrô esetében az adatok szórása kisebbnek bizonyult, mint az optikai tartomány esetében. A továbblépés nagyobb minta és távolabbi objektumok felhasználásával egyelőre még várat magára.

A fentiekből kitûnik, hogy az SCM még egyáltalán nem kiforrott, ahogy a minta nagysága és pontossága nő, újabb és újabb kalibrációra szorul. A módszer előnyeként kell megemlíteni, hogy kevésbé jól mintavételezett SN-k esetében is alkalmazható, mint az EPM, valamint rosszabb jel/zaj viszonyú adatok esetében is használható, ezáltal alkalmasabb lehet kozmológiai vizsgálatokra. Hátrány, hogy míg II-P típusú szupernóvák esetében a plató fázis közepén mérhetô fényesség még egy gyengébben mintavételezett fénygörbe esetében is elég jó pontossággal meghatározható, a sebesség mérése ezen módszer esetében is problémás. Egyrészt a távolabbi, halványabb szupernóváknál az észlelt spektrumok jel/zaj viszonya romlik, ami befolyásolja a sebességmérés pontosságát, bármely módszerrel is tesszük azt. Másrészt pedig - és ezt ritkán említik meg - a fényességgel ellentétben a sebesség jelentôsen változik a plató fázis során. Ahhoz, hogy megállapítsuk a robbanás utáni 50. napon mért sebességet, meg kell határoznunk a robbanás időpontját, ami - azon szerencsés esetek kivételével, amikor nagyon korai fázisban fedezik fel az SN-t - nem triviális feladat. Néhány napnyi bizonytalanság a robbanás időpontjának megállapításában legalább 200-300 kms ${ }^{-1}$ hibát okozhat a sebesség meghatározásában. 


\section{3. fejezet}

\section{Adatfeldolgozás}

Minden csillagászati objektum vizsgálatának alapját jelenti a jó minôségú adatok felvétele. A szupernóvák távolságmérése esetében, akár EPM-et akár SCM-et használunk, szükség van több színszúrôvel készített fénygörbére, valamint a tágulási sebesség értékére, amelyet a felvett spektrumból nyerhetünk ki. A mért távoláság pontosságát nagyban befolyásolja ezen adatok minősége.

Ennek a fejezetnek az első részében arról lesz szó, hogy a nyers képekből hogyan is áll elő a fénygörbe és a spektrum. Mindezt csak egész röviden, összefoglaló jelleggel ismertetem, hiszen ezen ismeretek az észlelő csillagászat alapjait jelentik, és számos magyar nyelvú részletes ismertető áll rendelkezésre a témában.

A fejezet második része annak leírását tartalmazza, hogy miként is lehet a SYNOW nevú parametrizált szupernóvaspektrum-modellező program segítségével a fotoszferikus sebesség mérését megtenni. Szó lesz a SYNOW múködésének részletes leírásáról, valamint a módszer alkalmazásának bemutatásáról. Ennek konkrét SN-kra történt alkalmazását, illetve az így kapott eredmények ismertetését már a következő fejezetek tartalmazzák.

\subsection{Nyers adatok feldolgozása}

A csillagászati észlelések történetében nagy ugrást jelentett a digitális képrögzítés és -feldolgozás megjelenése és elterjedése. Ma már szinte kizárólagosan CCD-chipeket használunk, a felvételek feldolgozására és az adatok kinyerésére rengeteg jól megírt programcsomag áll rendelkezésre, ilyen pl. a széles körben alkalmazott IRAF ${ }^{14}$ csomag. A képek felvételétôl az adatok kinyeréséig és kalibrációjáig sok lépésen keresztül vezet az út, ennek végén jó minőségű és nagy pontosságú fénygörbét és spektrumokat kaphatunk.

\subsubsection{Fotometria}

Az a folyamat, amelynek során nyers CCD-képek sorozatából összeáll egy fénygörbe, több lépésből áll. A nyers képeken először el kell végezni az alapvető korrekciókat, majd meg kell mérni az objektum fényességét, amelyet azután kalibrálni is szükséges. A megfelelően pontos fénygörbe eléréséhez mindegyik lépésre kellő figyelmet kell fordítani.

\footnotetext{
${ }^{14}$ http://iraf.noao.edu/
} 
Az objektumról készült nyers képeken különböző képkorrekciók elvégzése szükséges. A bias-korrekció a bias-szintet, míg a dark-korrekció a termikus elektronok miatt létrejött zajt korrigálja. A különböző szúrókkel készített flat-képek a CCD-kamera pixeleinek eltérő érzékenységét, valamint az egyes optikai elemeken esetleg lerakódott szennyeződéseket mutatják. A korrekciók elvégzését az IRAF programcsomag megfelelő task-jainak segítségével egyszerúen megtehetjük.

Az objektum, esetünkben a szupernóva fényességének mérésére alapvetôen három módszer áll rendelkezésünkre: az apertúra- illetve PSF-fotometria, valamint a képkivonásos technika. A megfelelố módszer kiválasztása annak alapján történik, hogy az objektum mennyire halvány, illetve milyen a közvetlen környezete, vannak-e a közelében más források is.

A legegyszerúbb az apertúra-fotometria használata. Ennek során a forrás körül megfelelően kijelölt kör alakú apertúrán belüli pixelek összintenzitását mérjük meg. Az égi háttér levonásához általában egy, az apertúrát körülvevố gyúrúben mérjük meg a pixelek átlagfényességét. Ez a módszer akkor alkalmazható, ha a háttér elég sima és a mérendő SN jóval fényesebb a környezeténél.

Halvány forrás esetén alkalmazhatunk PSF-fotometriát. A pontszerú fényforrás képe a leképezés során és a légkör zavaró hatása miatt eltorzul. A csillagok így létrejövő intenzitáseloszlását nevezzük ponteloszlás-függvénynek (point-spread function, PSF). Ha feltérképezzük a képen szereplő a csillagok PSF-jét, akkor ezek átlagára modellfüggvényt illeszthetünk, és meghatározhatjuk a képre jellemző PSF-et. Ezt aztán a kimérendő forrásra illesztve annak fényessége megmérhető. Mindezt véghez vihetjük az IRAF megfelelô csomagjainak használatával.

Egyes esetekben a képen az SN közvetlen környezetében más fényes források is találhatóak, vagy esetleg az objektum már rendkívül halvány. Ilyenkor érdemes a képlevonásos technikát alkalmazni. Ehhez rendelkeznünk kell egy olyan képpel, amely az SN megjelenése előtt vagy eltúnése után készuilt. Ezt a képet az SN-t tartalmazó felvételbôl le lehet vonni. A differenciaképen pedig - a már előzőleg elkészített PSF-profil felhasználásával elvégezhetjük a fényességmérést.

Bármely módszert alkalmazzuk is, a kapott fényességek még csak ,instrumentális” értékek, ahhoz, hogy mások munkájával összehasonlító méréseket kapjunk, kalibrálnunk kell ezeket. Minden szűrőrendszer esetében léteznek ún. standard csillagok, amelyek fényessége etalonként szolgál. Ezek felhasználásával kalibráltak ún. másodlagos standardmezôket. Az ilyen csillagmezőkben nagyszámú csillag fényességét határozták meg nagy pontossággal. A kalibrációhoz egy megfelelően tiszta éjszakán egy kiválasztott standard mezőt kell kimérnünk mindegyik szűrővel legalább kétszer, különböző levegőtömegnél. Az így készített képeken - feldolgozás után - megmérjük a standard csillagok instrumentális fényességét. Ezek és a standard magnitúdók összevetésével az eszközünkre és a fennálló körülményekre érvényes ún. távcsőkonstansokat és zéruspontokat állapíthatjuk meg. A $B V R I$ szúrő́k esetében ezt például az alábbi összefüggéseket felhasználva tehetjük meg:

$$
\begin{aligned}
& B-V=C_{B V} \cdot(b-v)-K_{B V} \cdot X+Z_{B V} \\
& V-R=C_{V R} \cdot(v-r)-K_{V R} \cdot X+Z_{V R} \\
& V-I=C_{V I} \cdot(v-i)-K_{V I} \cdot X+Z_{V I} \\
& V-v=C_{V} \cdot(V-I)-K_{V} \cdot X+Z_{V}
\end{aligned}
$$


Itt bvri az instrumentális, míg $B V R I$ a standard magnitúdókat jelenti, $X$ pedig a levegőtömeg. Ezek ismeretében $C, K$ és $Z$ konstansok már megállapíthatók.

Ezután a szupernóva területérôl az ugyanezen az éjszakán készült képeken választunk minél több egyedülálló csillagot, melyeknek megmérjük az instrumentális fényességét. A fenti egyenletek és a megállapított konstansok segítségével ezen összehasonlító csillagok magnitúdói kiszámolhatóak. Ezek felhasználásával már bármely éjszakán végzett mérések esetében egyszerú egyenesillesztéssel meg tudjuk állapítani az arra jellemző $Z^{\prime}=-K \cdot X+$ $Z$ zéruspontokat az adott idôpontban (a $C$ távcsôkonstansok értékei állandóak maradnak). A helyi összehasonlító csillagok fényességének meghatározását több éjszakán is érdemes elvégezni azért, hogy ezek értékei a lehető legpontosabbak legyenek.

A fotometria során a kapott fényességeket még korrigálnunk kell a köztünk és az SN közt elhelyezkedő por miatt fellépő vörösödésre is. A Tejútrendszerben található por által okozott vörösödés mértékét már elég jól kimérték (Schlafly \& Finkbeiner, 2011), de a szupernóva galaxisában található por mennyiségének becslése bonyolultabb probléma. Ennek megoldására általában a Na I D dublettjét használják, amelynek ekvivalens szélességéből (equivalent width, EW) következtetnek a vörösödés mértékére, általában a Munari \& Zwitter (1997), illetve a Turatto és mtsai (2003) által felállított korrelációt használva. Ezeket a korrelációkat nagy felbontású spektrumok felhasználásával állapították meg, viszont késôbb az irodalomban gyakran alkalmazták kis felbontású spektrumokra is, amikor a Na I D vonalai nem felbonthatóak. Poznanski és mtsai (2011) megmutatták, hogy ilyen spektrumok esetében ezek az összefüggések nem alkalmazhatók. 2012-es cikkükben 100 kvazár nagy felbontású, és közel egymillió, az SDSS katalógusában található kvazár és galaxis kis felbontású spektrumának használatával végeztek vizsgálatokat, és állapítottak meg összefüggést a Na I D ekvivalens szélessége és a vörösödés mértéke között. Eszerint, ha a dublett nem felbontható, a vörösödés mértéke:

$$
\log _{10} E(B-V)=1,17 \times E W(D 1+D 2)-1,85( \pm 0,08),
$$

ahol $E W(D 1+D 2)$ a Na I D két vonalának együttes ekvivalens szélessége (Poznanski és mtsai, 2012).

\subsubsection{Spektroszkópia}

A fotometriai képek feldolgozásához hasonlóan egy spektrum felvétele után is el kell végeznünk az alapvető képkorrekciókat (bias, flat). Ezután az IRAF megfelelő task-jainak használatával beállítjuk a spektrum helyzetének megfelelő apertúrát, és a háttér levonásával egyidejűleg kinyerhetjük magát a spektrumot. Következő lépésben még szükség van kalibrációra is. A hullámhossz-kalibrációhoz ún. spektrállámpa-képeket kell készíteni közvetlenül az objektumról készült spektrum felvétele előtt és után. Ezek ismert elemek vonalait tartalmazzák. A kinyert spektrállámpa-spektrum segítségével meg tudjuk határozni a jellemző diszperziós görbét, amelynek felhasználásával az SN spektrumának kalibrációja nagy pontossággal elvégezhetô. Mivel a mérőrendszer érzékenysége hullámhosszfüggő, az észlelt spektrum fluxuseloszlása eltorzul. Ennek korrigálására fluxukalibrációt kell végezni. Ehhez olyan csillagok spektrumát vesszük fel, amelyek spektrális energiaeloszlása ismert. A kettô összehasonlításával az érzékenységi görbét meg lehet határozni, és az SN spektrumán a 
szükséges korrekciót megtenni. A pontos kalibrációhoz a kapott spektrumot korrigálni kell a por miatti vörösödésre, valamint a vöröseltolódásra is.

Az ilyen módon kinyert és kalibrált spektrumokból meghatározhatjuk az EPM használatához szükséges tágulási sebességeket. Az általam használt módszer leírását a következő rész tartalmazza.

\subsection{Sebességmérés a SYNOW nevú program használatával}

A tágulási sebesség mérésére használt módszerek összefoglalásakor a 2.2.2 részben már szerepelt, hogy a legpontosabb sebességbecslési eljárásnak az tûnik, amelynek során NLTE atmoszféramodellek számításával modellezik a teljes spektrumot. Nagy hátránya ennek a módszernek, hogy jelentős számítási kapacitást igényel, ezért nagyszámú spektrum gyors feldolgozására alkalmatlan.

Ebből kiindulva ésszerú lépés, hogy egy jóval egyszerübb, de sokkal gyorsabb spektrummodellező program segítségével próbáljuk meg a sebességet meghatározni. Ehhez a SYNOW (Fisher, 1999; Hatano és mtsai, 1999) nevú FORTRAN nyelven megírt parametrizált szupernóvaspektrum-modellezó programot használtam, amely a fenti, NLTE-t használó, a sugárzásitranszfer-egyenletet megoldó programokkal ellentétben egyszerú alapfeltevések segítségével képes P-Cygni vonalprofilt mutató modellspektrumot létrehozni.

\subsubsection{A SYNOW alapjai}

A SYNOW a vonalak számításához néhány egyszerú alapfeltevést használ. Ezek a következők:

i) a szupernóváról ledobódott anyag homológ módon tágul,

ii) a fotoszféra fekete testként sugároz,

iii) a spektrumvonalak teljes mértékben a fotoszféra felett keletkeznek és

iv) keletkezésükért teljes mértékben a rezonáns szórás a felelős.

Ezen feltevések használatával a SYNOW a sugárzási transzferegyenletet az alábbiakban ismertetett ún. Sobolev-közelítéssel oldja meg (Kasen és mtsai, 2002).

Ha az atmoszférában a rezonáns szórás dominál, akkor a fotoszférából érkezó foton az atmoszféra azon részén tartózkodó atomon szóródik, ahol Doppler-eltolódott hullámhossza megfelel a rezonáns szóráshoz szükséges hullámhossznak. Az alábbi gondolatmenettel megmutatható, hogy homológ tágulás esetén az egyenlő radiális sebességû pontok egy, a látóirányra merôleges síkon helyezkednek el. Vegyünk két pontot, amelyek a középponttól $r_{1}$ és $r_{2}$ távolságra vannak, és $v_{1}$ illetve $v_{2}$ a sebességük. Tegyük fel, hogy a sebességük iránya a látóiránnyal $\phi_{1}$ és $\phi_{2}$ szöget zár be. A homológ tágulás miatt $v_{1} / v_{2}=r_{1} / r_{2}$. Vezessük be a 3.1. ábrán látható koordinátarendszert, ekkor $z_{1}=v_{1} \cdot \cos \phi_{1}$ és $z_{2}=v_{2} \cdot \cos \phi_{2}$. Ha a két pont radiális sebessége egyenlő: $v_{1} \cdot \cos \phi_{1}=v_{2} \cdot \cos \phi_{2}$, akkor következik, hogy $z_{1}=z_{2}$. Tehát az egyenlő radiális sebességú pontok egy $z=$ konstans koordinátájú, a látóirányra merôleges síkon helyezkednek el. 


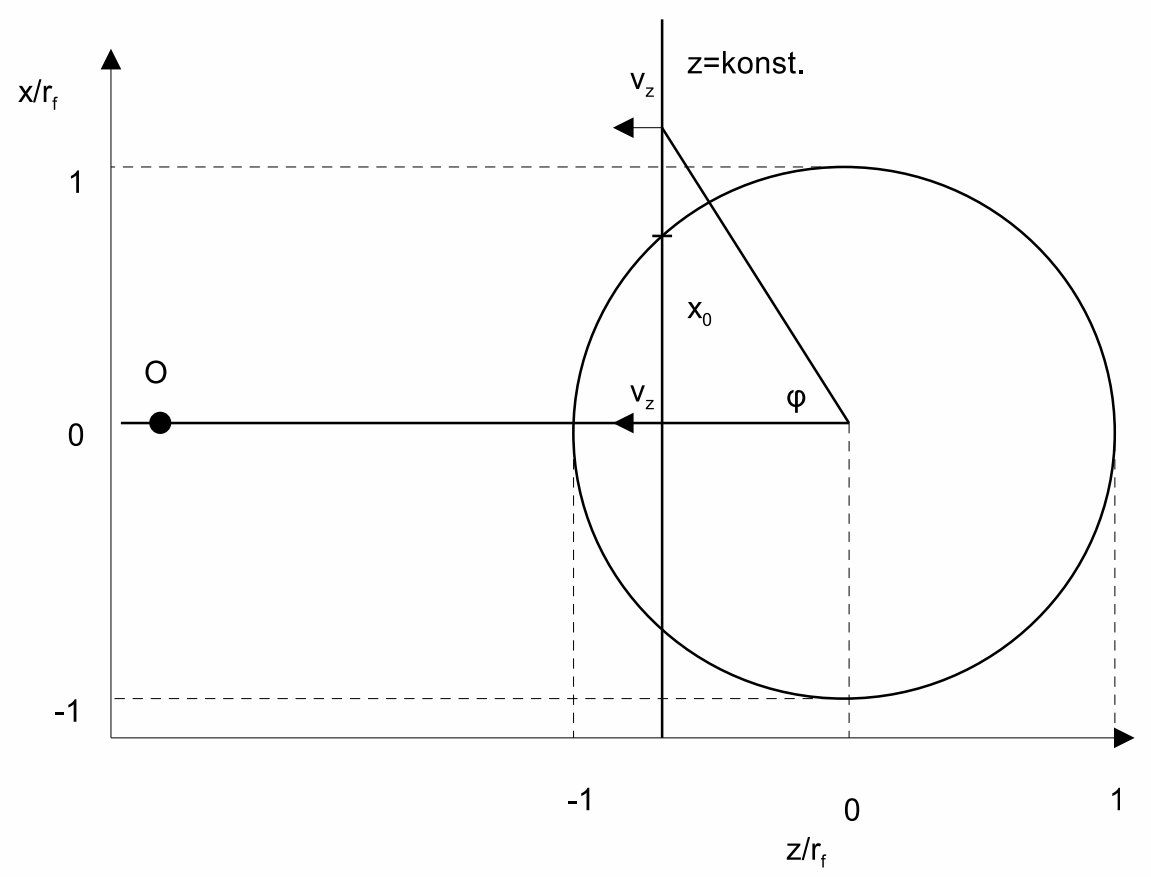

3.1. ábra. A Sobolev-közelítésben történő vonalprofilszámítást szemléltetô ábra.

Rezonáns szórás esetén ezek értelmében tehát minden azonos hullámhosszú foton egy $z=$ konstans koordinátájú síkról származik. Ha tehát egy adott hullámhosszon meg szeretnénk határozni a fluxus értékét, integrálnunk kell az adott síkról érkező összes sugárzást. Egy vonalprofil elkészítéséhez pedig ezt az atmoszférában lévő minden ilyen síkra meg kell tennünk és ábrázolnunk kell a fluxusokat a hullámhossz függvényében.

A P Cygni vonalprofil létrejöttéhez az atmoszféra három tartományát kell megvizsgálni (Kasen és mtsai, 2002; 3.1. ábra). A $z \geq 0$ tartományból érkező fotonok vöröseltolódást szenvednek a laboratóriumi hullámhosszhoz képest. Itt egy adott $z$ koordinátájú síkról érkezô fluxus:

$$
\frac{F(\lambda)}{4 \pi}=\int_{0}^{r_{f}} I_{f} x d x+\int_{r_{f}}^{\infty} S(r)\left(1-e^{-\tau(r)}\right) x d x=\frac{1}{2} r_{f}^{2} I_{f}+\int_{r_{f}}^{\infty} S(r)\left(1-e^{-\tau(r)}\right) x d x,
$$

ahol $I_{f}$ a fotoszféra sugárzásának intenzitása, $r_{f}$ a fotoszféra sugara, $S(r)$ a forrásfüggvény, $\tau(r)$ az optikai mélység. Az egyenlet első tagjánál a sugárzás közvetlenül a fotoszféráról érkezik, míg a második tag a fotoszféra feletti közegben szóródó fotonokból származik.

A második tartományban $\left(-r_{f}<z<0\right)$ már a fotoszféra és a megfigyelő közötti anyagban fellépó abszorpció is befolyásolja a fluxust. Az alábbi kifejezésben ezt a harmadik tag képviseli.

$$
\frac{F(\lambda)}{4 \pi}=\int_{0}^{x_{0}} I_{f} x d x+\int_{x_{0}}^{\infty} S(r)\left(1-e^{-\tau(r)}\right) x d x+\int_{x_{0}}^{r_{f}} I_{f} e^{-\tau(r)} x d x
$$


ahol $x_{0}=\sqrt{r_{f}^{2}-z^{2}}$

A harmadik tartományból - ahol $z \leq-r_{f}$ - érkező fluxus pedig:

$$
\frac{F(\lambda)}{4 \pi}=\int_{0}^{\infty} S(r)\left(1-e^{-\tau(r)}\right) x d x+\int_{0}^{r_{f}} I_{f} e^{-\tau(r)} x d x
$$

A három fenti egyenletet egyben összefoglalva a következőt kapjuk:

$$
\frac{F(\lambda)}{4 \pi}=\int_{0}^{x_{0}} I_{f} x d x+\int_{x_{0}}^{\infty} S(r)\left(1-e^{-\tau(r)}\right) x d x+\int_{x_{0}}^{r_{f}} I_{f} e^{-\tau(r)} x d x
$$

ahol

$$
x_{0}= \begin{cases}r_{f} & \text { ha } 0 \leq z \\ \sqrt{r_{f}^{2}-z^{2}} & \text { ha }-r_{f}<z<0 \\ 0 & \text { ha } z \leq-r_{f}\end{cases}
$$

Ha az így kiszámolt fluxusokat ábrázoljuk a hullámhossz függvényében, szépen kirajzolódik a táguló atmoszféra által körülvett forrásokra jellemző P Cygni vonalprofil.

\subsubsection{Spektrumok modellezése a SYNOW-val}

A SYNOW futtatása során több paramétert kell egyszerre megválasztani és beállítani. Megadjuk a fotoszféra hőmérsékletét $\left(T_{b b}\right)$, ebből számítja ki a program azt a feketetestgörbét, amely a kontinuumot adja. Be kell állítani azt, hogy az atmoszféra megy rétegében keletkeznek a vonalak, ez az alsó és felsô határréteghez tartozó sebesség megadásával lehetséges $\left(v_{\min }\right.$ és $\left.v_{\max }\right)$. Megadjuk a fotoszféra tágulási sebességét is $\left(v_{\text {fot }}\right)$. Kiválasztjuk, hogy mely atomok és ionok kerüljenek bele a modellspektrumba. A Sobolev-közelítésben egy vonal optikai mélysége:

$$
\tau=\left(\frac{\pi e^{2}}{m_{e} c}\right) f \lambda t n_{l}\left(1-\frac{g_{l} n_{u}}{g_{u} n_{l}}\right)
$$

ahol $n_{u}$ és $n_{l}$ a koncentráció az átmenet felsô és alsó szintjén, $g_{u}$ és $g_{l}$ statisztikus súlyok (az egyes energiaszintek elfajultságát fejezik ki), $f$ az oszcillátorerősség (annak a valószínúsége, hogy az adott átmenet bekövetkezik), $t$ a robbanás óta eltelt idő, $e$ az elektron töltése, $m_{e}$ a tömege, $c$ a fénysebesség. A SYNOW modellezés során az adott atom/ion egy referenciavonalának (amely általában a legerôsebb vonal) optikai mélységét kell megadni $\left(\tau_{\text {ref }}\right)$. A program ezután a többi vonal erősségét ebből számítja ki, méghozzá - lokális termodinamikai egyensúly (LTE) közelítést használva - a Boltzmann-formula alapján, amihez a gerjesztési hőmérsékletet $\left(T_{\text {exc }}\right)$ szintén meg kell adnunk:

$$
\frac{n_{i}}{n_{0}}=\frac{g_{i}}{g_{0}} e^{\frac{-\left(E_{i}-E_{0}\right)}{k T_{e x c}}}
$$

Az optikai mélység az atmoszférában a sebesség (azaz a sugár) függvényében változhat, használhatunk exponenciális vagy hatványfüggvényt, illetve - a program újabb verziójában Gauss-függvényt is. Bármelyiket is alkalmazzuk, meg kell adnunk a függvénykitevô kívánt értékét $(n)$. 
3.2. Sebességmérés a SYNOW nevú program használatával

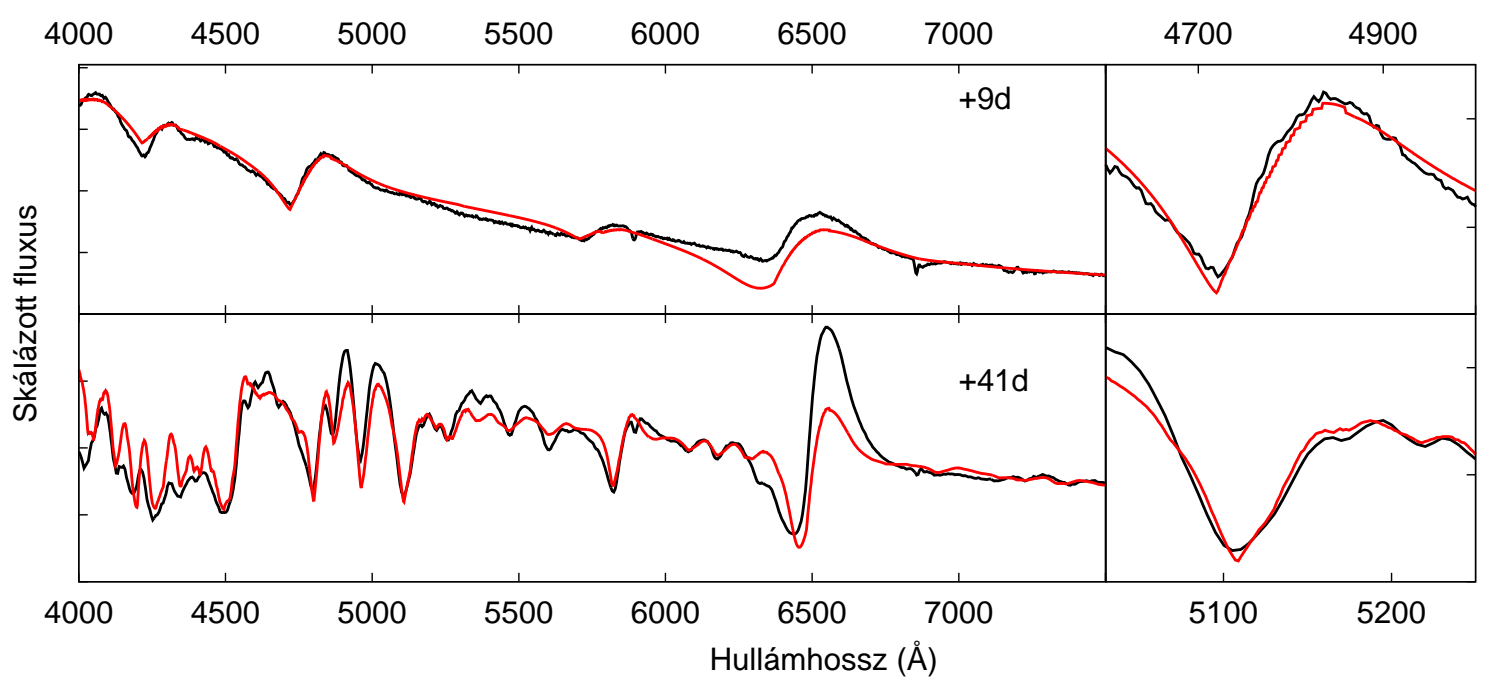

3.2. ábra. Az SN 1999em észlelt (fekete) és modellezett spektruma (piros) a robbanás után 9 (fent) és 41 nappal (alul). A jobb oldalon kinagyítva látható azoknak a vonalaknak a tartománya (Hß, fent, Fe II 5169 Å, lent), amelyek segítségével meghatároztam a sebességet.

A SYNOW-t folyamatosan fejlesztik, ennek köszönhetően már több verzió létezik. Az 1.0 verzióban még $n$ választott értéke egyszerre minden vonal számítása esetében érvényes volt, míg a 2.0 verziónál ez már minden atom/ion esetében külön-külön megadható. A legújabb verziója a FORTRAN helyett $\mathrm{C}++$ nyelven megírt $\mathrm{SYN}++{ }^{15}$, illetve a paraméter-optimalizást is lehetôvé tevő SYNAPPS (Thomas és mtsai, 2011). Ezeket Ia SN-k spektrumának modellezésére fejlesztették, emiatt egyelőre az optikai mélység változását csak exponenciális függvényként képesek kezelni, ami II-P SN-k esetében kevésbé jó illesztést eredményez.

Az észlelt spektrumok SYNOW modellezése a következő lépések szerint zajlott. Először készítettem egy modellt, amely az észlelt spektrumot nagyjából jól leírja, megbecsülve a paraméterek körülbelüli értékét. A II-P SN-k esetében az optikai mélység változását általában hatványfüggénnyel lehet legjobban leírni, a modellezés során végig ezt használtam. A szabad paraméterek számának csökkentése érdekében $n$ minden atom/ion esetében ugyanaz volt.

Következő lépésként a $\tau_{\text {ref }}, n$ és $v_{\text {fot }}$ értékeit széles tartományon változtatva nagyszámú modellt hoztam létre. Azért, hogy a szabad paraméterek száma minél kisebb legyen, $T_{b b}$ értékét - amely a vonalak alakjára nincs közvetlen hatással, és a kezdeti modell készítésekor elég pontosan meghatározható - változatlanul hagytam. Ezenkívül - feltételezve, hogy a spektrumvonalak mindegyike a fotoszféra közelében keletkezik $-v_{\min }-\mathrm{t}$ jóval a fotoszféra alatt, $v_{\max }$-ot pedig fölötte tartottam, állandó értéken.

A létrehozott modellek közül $\chi^{2}$-es illesztéssel kerestem meg azt, amely legjobban illeszkedik az észlelt spektrumra. Ezután a változtatandó paraméterek értéktartományát és a lépésközt megfelelően szúkítve többször is újra megismételtem a számításokat és az illesztést.

A fenti lépések segítségével viszonylag rövid idő alatt meg lehet találni azokat a paramétereket és kémiai összetevőket, amelyek legjobban leírják az észlelt spektrumot. A 3.2.

15 https://c3.lbl.gov/es/ 

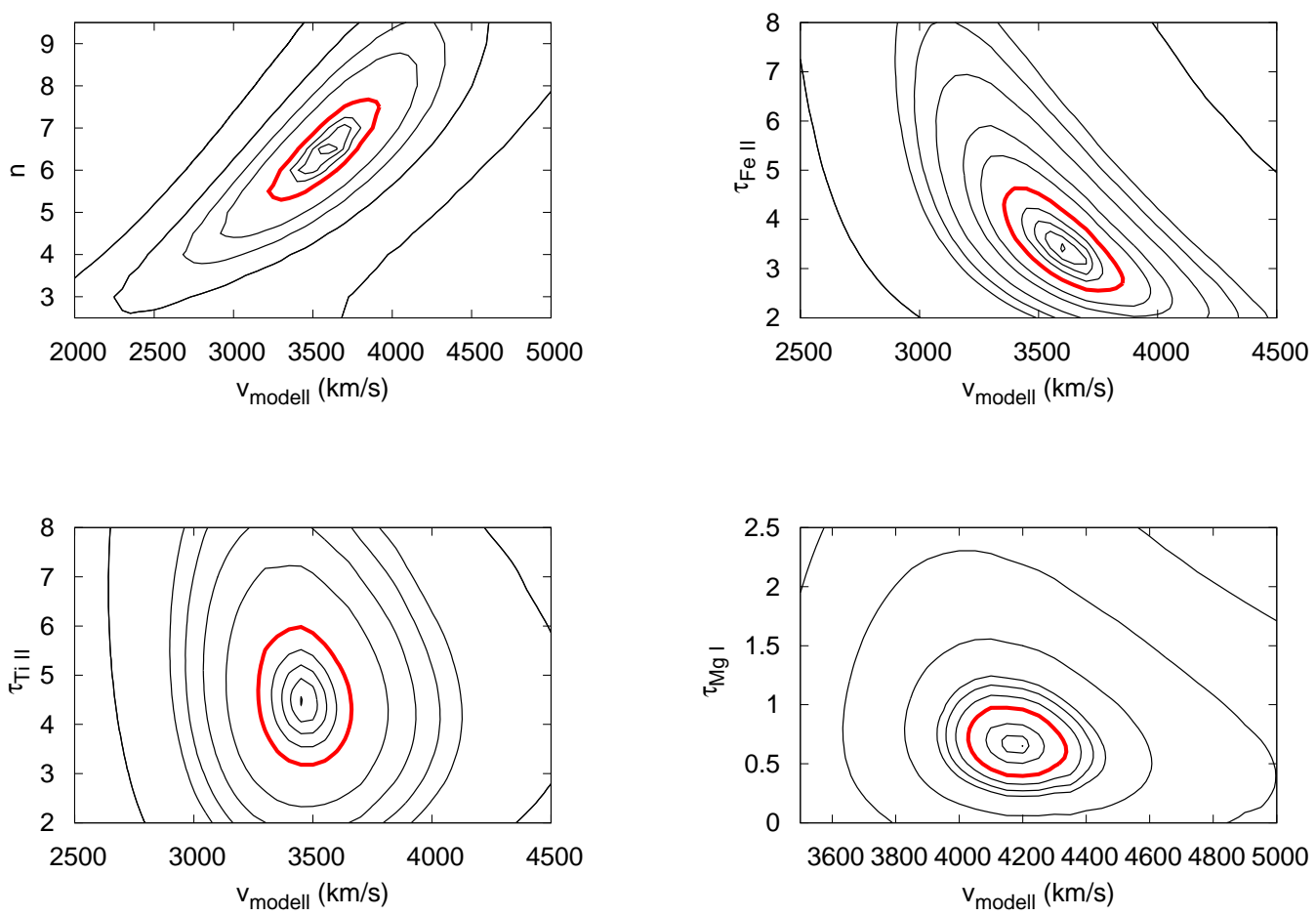

3.3. ábra. A $v_{\text {modell }}$ többi paramétertôl való függésének vizsgálata a $\chi^{2}$ minimuma körüli kontúrok segítségével. A $v_{\text {modell }}$ értéke egyértelmú korrelációt mutat az optikai mélység változását leíró hatványfüggvény $n$ kitevőjével (bal fenti kép) valamint az Fe II referenciavonalának $\tau_{\text {ref }}$ optikai mélységével (jobb fent). Nem figyelhetố meg viszont egyértelmú kor-

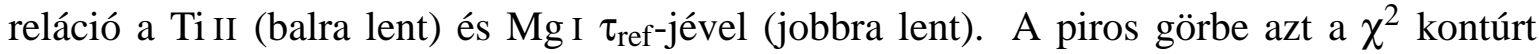
mutatja, mely 50\%-kal nagyobb a minimum értékénél.

ábrán példaként látható egy korai és egy késôi fázisban észlelt spektrum együtt a legjobb modellel. Látható, hogy a modell - a H $\alpha$ vonal kivételével - nagyon jól illeszkedik az észlelésre.

\subsubsection{A fotoszferikus sebesség meghatározása}

Mivel a modellezés fő célja ebben az esetben a fotoszféra tágulási sebességének mérése, az illesztés utolsó lépése ennek értékének a finomítása volt. Az összes többi paramétert rögzítve olyan modelleket készítettem, amelyek csak a $v_{\text {fot }}$ paraméter értékében különböztek. A lépésköz $50 \mathrm{kms}^{-1}$ volt. A $\chi^{2}$-es illesztés ebben az esetben már nem a spektrum egészére történt, hanem egy kiválasztott vonal hullámhossztartományára.

Dessart \& Hillier (2005b) megmutatták, hogy az Fe II 5169 Å vonal abszorpciós minimuma Doppler-eltolódásából mért sebesség szoros korrelációt mutat a fotoszferikus sebességgel. Ezért ezt a vasvonalat választottam a legmegfelelőbb $v_{\text {fot }}$ értékkel jellemezhetô modell kiválasztására. Korai fázisban készült spektrumok esetében, a vasvonalak megjelenése előtt a H $\beta$ vonalat használtam ugyanerre a célra. A legjobban illeszkedố modell $v_{\text {fot }}$ paraméterét fogadtam el, mint az észlelt spektrum fotoszferikus sebességét. A továbbiakban 
erre az értékre mint $v_{\text {modell }}$ hivatkozom. A kapott $v_{\text {modell }}$ hibájának mértékét a $\chi^{2}$ függvény minimuma körüli 90 százalékos konfidenciaintervallum határozta meg.

A 3.2. ábrán kinagyítva látható a korai spektrum esetében a $H \beta$, a későbbinél pedig a Fe II $5169 \AA$ környéke, azokkal a modellspektrumokkal együtt, amelyek alapján a $v_{\text {modell }}$ értékét megkaptam. Látható, hogy ezek a modellek mindkét esetben nagyon jól illeszkednek a teljes vonalprofilra.

A fent leírt módon történő sebességmeghatározásnak számos lehetséges hibaforrása van. Ezek egyrésze a modellezôprogram által használt egyszerúsítő feltevésekből fakadnak. Az 5. fejezetben azonban megmutatom, hogy ha a $v_{\text {modell }}$ értékeit összevetjük olyan sebességekkel, amelyeket mások NLTE modellek alapján kaptak, akkor nem találunk szisztematikus eltérést a kettő között, a sebességek kb. 10\%-on belül jó egyezést mutatnak.

Másik lehetséges hibaforrást az egyes paraméterek közti összefüggések jelentik. Nehéz megbecsülni, hogy az egyes paraméterek pontatlanabb beállítása mennyiben befolyásolja egy másik paraméter, ebben az esetben leginkább $v_{\text {fot }}$ értékét. Ez olyan spektrumok esetében lehet elsôsorban fontos, amelyeknek rosszabb a jel/zaj viszonya, ezért az illesztés is nagyobb hibával terhelt. A 3.3. ábrán a $\chi^{2}$-függvény minimuma körüli kontúrok ábrázolásával megvizsgáltam több paraméter esetében is, hogy ezek változtatása milyen mértékben befolyásolja $v_{\text {modell }}$ értékét. Látható, hogy jelentősebb korreláció csak a vasvonal megadott optikai mélysége $\left(\tau_{\mathrm{Fe}}\right)$, valamint az $n$ hatványkitevő esetében figyelhetô meg. A másik két vizsgált elem esetében egyértelmú összefüggés nem áll fenn. Az is észrevehetô, hogy mind $\tau_{\mathrm{Fe}}$, mind $n$ szignifikáns megváltozása esetén a $\chi^{2}$-es illesztés során kapott $v_{\text {modell }}$ érték csak néhány száz $\mathrm{kms}^{-1}$ nagyságban változik. Ez pedig nem haladja meg azt a bizonytalanságot, amely a spektrum felbontása miatt jelen van (tipikusan $200-300 \mathrm{kms}^{-1}$ ).

Hibát okozhat az, hogy a sebességmeghatározás végső lépésében egy szúk, szubjektíven választott hullámhossztartományt veszek figyelembe az illesztéshez. Azonban vizsgálataim azt mutatták, hogy ennek a tartománynak az - ésszerú kereteken belüli - változtatása csak minimális mértékben, hibahatáron belül befolyásolja az eredményt.

A következkező fejezetekben a SYNOW-val történő sebességmérést 6 szupernóva esetében alkalmazom, majd az így kapott eredmények segítségével elemzem a módszer előnyeit és hátrányait, valamint az sebességeket összevetem a más eljárások által szolgáltatottakkal. 


\section{4. fejezet}

\section{Eredmények}

A következőkben hat II-es típusú szupernóva (4.1. táblázat) nagyszámú spektruma vizsgálatának eredményét ismertetem. Mindegyik objektum esetében megmértem a tágulási sebességet több, a 2.2.2 fejezetben tárgyalt módszer használatával, így összehasonlíthatjuk az különböző eljárásokat. A spektrumokat a SYNOW-val modelleztem, egyúttal alkalmaztam a 3.2 fejezetben leírt sebességmérési módszert is.

Az itt szóbakerülő SN-k közül öt adatai elsősorban mások által publikált munkákból származnak. Ezen objektumok mindegyikérôl nagy mennyiségú adat áll rendelkezésre, és az irodalomban már részletesen elemezték ôket. Több esetben EPM-mel, illetve SCM-mel történő távolságmérésre is sor került. Ennek köszönhetően alkalmasak a sebességmérési eljárások vizsgálatára, összehasonlítására, valamint arra, hogy az újonnan kapott sebességek felhasználásával kiszámolt távolságokat mások korábbi eredményeivel összevessem.

A SYNOW-val végzett modellezés során kapott sebességeket ( $\left.v_{\text {modell }}\right)$ igyekeztem minél több egyéb eljárással meghatározott értékkel összehasonlítani:

i) Megmértem a H $\beta$ és az Fe II $5169 \AA$ ̊̊ vonalak Doppler-sebességét ( $v_{\mathrm{H} \beta}$ és $v_{\mathrm{Fe}}$ ) minden lehetséges esetben.

ii) Az SN 1999em, 2005cs és 2006bp esetében Dessart \& Hillier (2006) és Dessart és mtsai (2008) a CMFGEN kód használatával elkészítették a SN-k modellspektrumait. Az általuk kapott fotoszferikus sebességek $\left(v_{\text {nlte }}\right)$ is szerepet kapnak az összevetésben.

iii) A keresztkorrelációs módszert is alkalmaztam, hogy az így kapott sebességeket is belevehessem az összehasonlításba. A módszer alkalmazásához (2.2.2 fej.) összehasonlító spektrumokra van szükség. Két készletet állítottam össze ebből a célból, az elsô az SN 1999em 22 észlelt spektrumát tartalmazta (\#1), a második pedig a fent említett CMFGEN modellspektrumokból állt (\#2). Az első esetben a spektrumokhoz rendelt sebesség szerepét a $v_{\mathrm{Fe}}$ töltötte be, míg második esetben $v_{\text {nlte }}$. A keresztkorrelációval kapott sebességekre a $v_{\mathrm{cc \# 1}}$ és $v_{\mathrm{cc} \# 2}$ jelöléseket használom a továbbiakban.

A kapott $v_{\text {modell }}$ értékek felhasználásával kiszámítottam a távolságot az EPM alkalmazásával. Mivel a fotometriai és spektroszkópiai mérések ritkán egyidejúek, ezért az fényességeket interpoláltam a sebességmérések időpontjaira (kivéve az SN 2004dj esetében, ld. 4.2. fej.). Összehasonlításképpen a távolságokat a $v_{\mathrm{Fe}}$ sebességek segítségével is meghatároztam. Az EPM alkalmazása során minden esetben Dessart \& Hillier (2005b) korrekciós faktorait és az $S=\{B V R I\}$ szűrőkombinációt használtam. 
4.1. táblázat. Az itt szereplő szupernóvák fizikai paramétereinek összefoglalása.

\begin{tabular}{lcccccc}
\hline SN & $\begin{array}{c}\mathrm{t}_{0} \\
(\mathrm{JD}-245000)\end{array}$ & $\begin{array}{c}\text { Távolság } \\
(\mathrm{Mpc})\end{array}$ & $\begin{array}{c}\mathrm{cz}^{1} \\
\left(\mathrm{~km} \mathrm{~s}^{-1}\right)\end{array}$ & $\begin{array}{c}\mathrm{E}(\mathrm{B}-\mathrm{V}) \\
(\mathrm{mag})\end{array}$ & $\begin{array}{c}M_{\mathrm{prog}} \\
\left(\mathrm{M}_{\odot}\right)\end{array}$ & Hivatkozások $^{2}$ \\
\hline SN 1999em & 1477,0 & $7,5-12,5$ & 717 & 0,10 & $<15$ & $1,2,3,4,5,6,7,8$ \\
SN 2004dj & 3187,0 & $3,2-3,6$ & 131 & 0,07 & $12-20$ & $9,10,11,12,13,14,15$ \\
SN 2004et & 3270,5 & $4,7-6,0$ & 48 & 0,41 & $9 ; 15-20$ & $16,17,18,19,20,21,22$ \\
SN 2005cs & 3549,0 & $7,1-8,9$ & 463 & 0,05 & $6-13$ & $23,24,25,26,27,28,29$ \\
SN 2006bp & 3835,0 & $17,0-18,3$ & 987 & 0,40 & $12-15$ & 26,30 \\
SN 2011dh & 5713,0 & $7,1-8,9$ & 463 & 0,04 & $13-16$ & $25,26,31,32,33,34,35,36$ \\
\hline
\end{tabular}

${ }^{1}$ NED, http: //nedwww.ipac.caltech.edu/

2 Források: (1) Hamuy és mtsai (2001), (2) Leonard és mtsai (2002), (3) Smartt és mtsai (2002), (4) Leonard és mtsai (2003), (5) Elmhamdi és mtsai (2003), (6) Baron és mtsai (2004), (7) Dessart \& Hillier (2006), (8) Utrobin (2007), (9) Maíz-Apellániz és mtsai (2004), (10) Kotak és mtsai (2005), (11) Wang és mtsai (2005), (12) Chugai és mtsai (2005), (13) Zhang és mtsai (2006), (14) Vinkó és mtsai (2006), (15) Vinkó és mtsai (2009), (16) Li és mtsai (2005), (17) Sahu és mtsai (2006), (18) Misra és mtsai (2007), (19) Utrobin \& Chugai (2009), (20) Poznanski és mtsai (2009), (21) Maguire és mtsai (2010b), (22) Crockett és mtsai (2011), (23) Maund és mtsai (2005), (24) Pastorello és mtsai (2006), (25) Takáts \& Vinkó (2006), (26) Dessart és mtsai (2008), (27) Eldridge és mtsai (2007), (28) Utrobin \& Chugai (2008), (29) Pastorello és mtsai (2009), (30) Immler és mtsai (2007), (31) Vinkó és mtsai (2012a), (32) Maund és mtsai (2011), (33) Van Dyk és mtsai (2011), (34) Soderberg és mtsai (2012), (35) Bersten és mtsai (2012), (36) Benvenuto és mtsai (2012) 


\section{1. $\mathrm{SN} 1999 \mathrm{em}$}

Az SN 1999em az egyik legjobban észlelt és legalaposabban tanulmányozott II-P típusú szupernóva. Az NGC 1637 jelú galaxisban fedezte fel Li 1999. október 29-én, rendkívül korai fázisban (Li, 1999). Leonard és mtsai (2002), Hamuy és mtsai (2001) valamint Elmhamdi és mtsai (2003) közel 500 napon keresztül készítettek róla felvételeket, ennek köszönhetôen az SN fénygörbéje nagyon jó időbeli felbontású.

Errôl az SN-rôl rendkívül nagyszámú cikk született. Annak a kevés szupernóvának az egyike, amelyrôl spektropolarimetriai vizsgálatokat is végeztek. Leonard és mtsai (2001) csak kismértékú aszimmetria nyomait találták a plató fázis során, amely valamennyire megnövekedett a nebuláris fázisban. Dessart \& Hillier (2005a) erre az SN-re (az SN 1987Aval együtt) alkalmazták először a CMFGEN atmoszféramodellező kódjukat, és ezzel jelentős eredményeket értek el a II-P SN-k plató fázisában uralkodó körülmények megértésében. A készített spektrumokat aztán egy későbbi cikkben arra is felhasználták, hogy az EPM használatához elengedhetetlenül szükséges korrekciós faktorok értékeit meghatározzák (ld. 2.2.3 fej.)

Smartt és mtsai (2002) a HST archív felvételeinek vizsgálata alapján az SN szülőcsillaga tömegének felső határát tudták megbecsülni $\left(M_{\text {ZAMS }}<15 \mathrm{M}_{\odot}\right)$. Utrobin (2007) NLTE hidrodinamikai modellek készítése és vizsgálata során a ledobódott burok tömegét jelentősen nagyobbnak, 19,0 $\pm 1,2 \mathrm{M}_{\odot}$ értékúnek becsülte. Számításai szerint a robbanás energiája $(1,3 \pm 0,1) \times 10^{51}$ erg nagyságú volt, míg a keletkezett ${ }^{56} \mathrm{Ni}$ tömege $0,036 \pm 0,009 \mathrm{M}_{\odot}$-nek adódott.

A különböző tanulmányok némileg eltéően állapították meg a robbanás időpontját, a következőkben a különböző értékek átlagát, a 2451477,0 $\pm 2,0$ JD értéket használom (Leonard és mtsai, 2002; Hamuy és mtsai, 2001; Dessart \& Hillier, 2006). A vörösödés mértékét mindegyik tanulmány alacsonynak becsülte, a többség az $E(B-V)=0,10 \pm 0,05$ magnitúdó értéket használta, a továbbiakban az ő példájukat követem. A 4.1.1 részben a Leonard és mtsai (2002) valamint Hamuy és mtsai (2001) által felvett, a SUSPECT (The Online Supernova Spectrum Archive ${ }^{16}$ ) adatbázisból szabadon letölthetô spektrumokat elemzem. A 4.1.2 részben, a távolságmeghatározás során Leonard és mtsai (2002), Hamuy és mtsai (2001) valamint Elmhamdi és mtsai (2003) által készített fotometriai méréseket használom fel.

\subsubsection{Spektrummodellezés és sebességmérés}

Az SN 1999em plató fázis során készült 22 db elérhető spektruma a robbanás utáni első 80 napot fedi le. Elkészítettem ezen spektrumok SYNOW modelljét a 3.2.1 fejezetben leírt eljárás használatával. Ezek a 4.1. ábrán láthatók az észlelt spektrumokkal együtt, míg a modellek legfontosabb paraméterei az A.1 táblázatban találhatók. Az elsô hat, korai fázisban készült spektrum még csak a H I és a He I vonalait tartalmazta, előbbiek egyre erősebbé váltak az SN fejlődése folyamán. Az utóbbi egyre gyengült, majd a hetedik, a robbanás után 14 nappal készült spektrumban megjelent mellette a $\mathrm{Na}$ I $\mathrm{D}$ dublett vonala, amely késóbb egyre erősödött.

A robbanást követő 15. nap után megjelentek a spektrumban az Fe II, a Ti II, a Ba II, a

\footnotetext{
$1{ }^{16}$ http://suspect.nhn.ou.edu/ suspect/
} 
4.2. táblázat. Az SN 1999em különböző módszerekkel kapott tágulási sebessége.

\begin{tabular}{ccccc}
\hline \hline $\begin{array}{c}\text { fázis } \\
\text { (nap) }\end{array}$ & $\begin{array}{c}v_{\text {modell }} \\
\left(\mathrm{kms}^{-1}\right)\end{array}$ & $\begin{array}{c}v_{\mathrm{H} \beta} \\
\left(\mathrm{kms}^{-1}\right)\end{array}$ & $\begin{array}{c}v_{\mathrm{Fe}} \\
\left(\mathrm{kms}^{-1}\right)\end{array}$ & $\begin{array}{c}v_{\mathrm{cc \# 2}} \\
\left(\mathrm{kms}^{-1}\right)\end{array}$ \\
\hline 4,79 & $11050(300)$ & $11332(300)$ & - & $10341(454)$ \\
5,84 & $10900(350)$ & $11101(300)$ & - & $9858(888)$ \\
6,84 & $9950(250)$ & $10141(300)$ & - & $9112(878)$ \\
7,64 & $8900(200)$ & $9148(250)$ & - & $8383(832)$ \\
8,67 & $8850(150)$ & $8697(250)$ & - & $8544(491)$ \\
12,84 & $8550(500)$ & $8406(250)$ & $7236(250)$ & $8513(497)$ \\
14,14 & $7350(500)$ & $7913(300)$ & $6829(300)$ & $7575(289)$ \\
14,67 & $8150(350)$ & $7992(250)$ & $7213(250)$ & $7708(190)$ \\
15,14 & $7650(150)$ & $7802(250)$ & $6793(250)$ & $7380(187)$ \\
19,67 & $6750(200)$ & $7246(250)$ & $6019(250)$ & $6703(242)$ \\
24,66 & $6150(300)$ & $6393(250)$ & $5146(250)$ & $5779(126)$ \\
24,84 & $6150(225)$ & $6450(250)$ & $5172(250)$ & $5866(194)$ \\
27,84 & $5000(200)$ & $6060(250)$ & $4773(250)$ & $5446(155)$ \\
29,84 & $4650(250)$ & $5816(250)$ & $4693(250)$ & $5221(201)$ \\
33,84 & $4300(100)$ & $5251(250)$ & $4312(250)$ & $4394(215)$ \\
37,84 & $3900(100)$ & $4885(250)$ & $4083(250)$ & $4521(159)$ \\
41,04 & $3600(200)$ & $4164(250)$ & $3421(250)$ & $3691(115)$ \\
47,84 & $3200(400)$ & $3822(300)$ & $3528(300)$ & $3765(163)$ \\
50,74 & $3400(150)$ & $3699(250)$ & $3435(250)$ & $3661(131)$ \\
51,76 & $2800(350)$ & - & $3183(250)$ & $3147(152)$ \\
66,76 & $2300(100)$ & $2645(250)$ & $2869(200)$ & $3097(146)$ \\
79,84 & $1800(400)$ & $1928(250)$ & $2313(250)$ & $1634(100)$ \\
\hline
\end{tabular}

Ca II és az Sc II vonalai. A 35. naptól kezdve az Si I és Si II vonalait is kimutatta a modellezés.

A sebességmeghatározást az első 6 spektrum esetében a $\mathrm{H} \beta$ vonalra történő illesztéssel végeztem, míg a maradék 16-nál ez már a Fe II 5169 Å vonal használatával is lehetséges volt. Az így kapott sebességek 11000 és $1800 \mathrm{kms}^{-1}$ közé esnek (4.1. ábra, 4.2. táblázat).

Korai spektrumok esetében a vonalminimumból mért $v_{\mathrm{H} \beta}$ és $v_{\text {modell }}$ nagyon hasonló, míg késóbbi fázisban az előbbi értékei valamivel magasabbak. A robbanást követô 15. és 40.

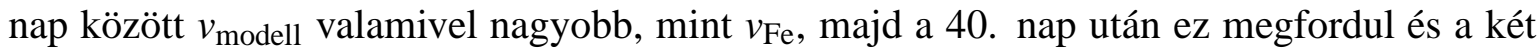
sebesség különbsége egyre növekszik.

A Dessart \& Hillier (2006) által a CMFGEN modellezés során kapott sebességek elég jó egyezést mutatnak a $v_{\text {modell }}$ értékekkel. Az észlelt spektrumok keresztkorreláltatása a \#2

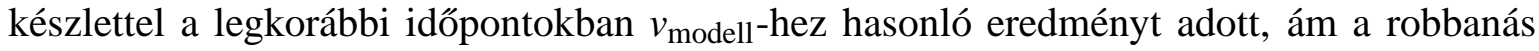
utáni 22. és 80. nap között már jelentôsebb nagyobb volt annál. Ebben az idôszakban $v_{\mathrm{cc} \# 2}$ értékei $v_{\mathrm{H} \beta}$ és $v_{\mathrm{Fe}}$, közé esnek. Ez teljesen érthető, hiszen a keresztkorreláció során a 4500 $5500 \AA$ hullámhossztartományt használtam, amelybe mind a H $\beta$, mind az FeII 5169 A vonal beleesik. 


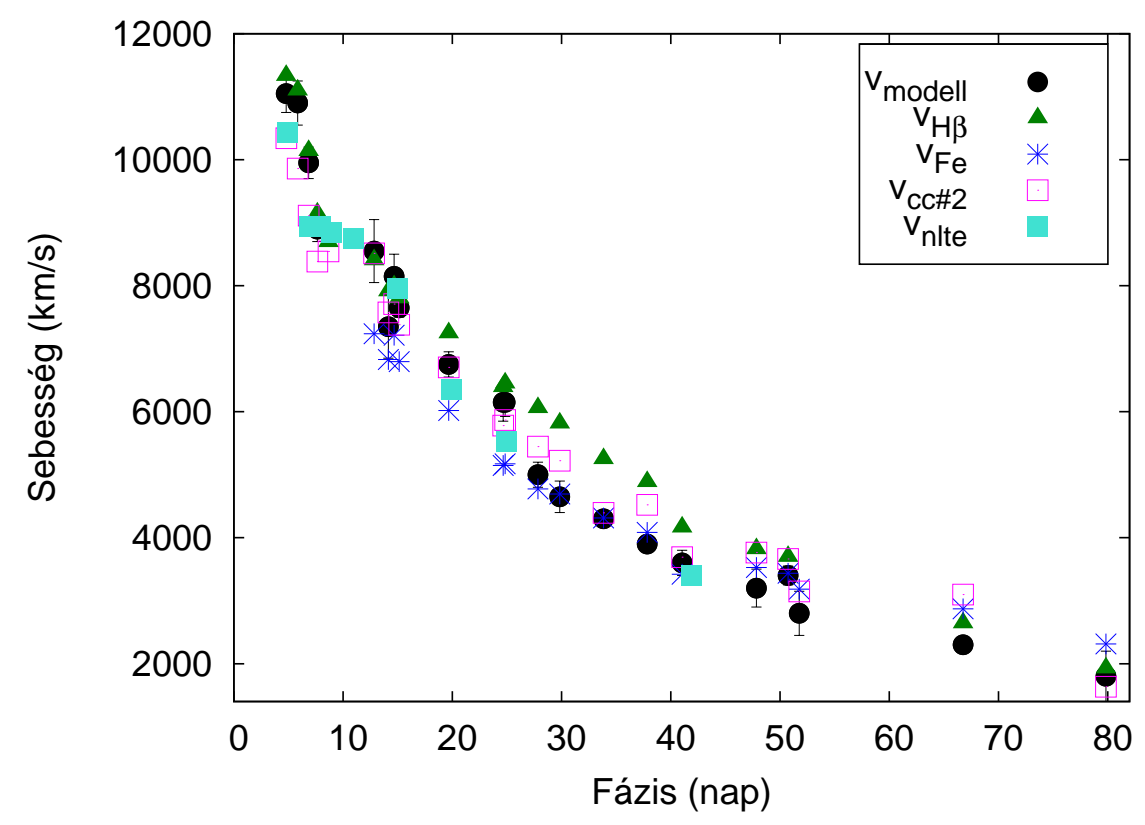

4.1. ábra. Az SN 1999em sebességének különböző módszerekkel mért értékei.

\subsubsection{Távolság}

Az SN 1999em távolságát több alkalommal, több csoport is meghatározta az EPM alkalmazásával (4.3. táblázat). Hamuy és mtsai (2001) a sebességmeghatározást keresztkorrelációs módszerrel végezték, melyhez Eastman és mtsai (1996) modellspektrumait használták. A távolságot Eastman és mtsai (1996) korrekciós faktorainak ( $\zeta_{\text {E96 }}$ ) alkalmazásával 7,8 \pm 0,5 Mpc-nek számolták. Ugyanezekkel a korrekciós faktorokkal, viszont különböző spektrumvonalak abszorpciós minimumából számolt sebességek felhasználásával Leonard és mtsai (2002) 8,2 \pm 0,6 Mpc-et, míg Elmhamdi és mtsai (2003) 7,8 \pm 0,3 Mpc-et kaptak. Azonban nem sokkal ezután összehasonlításképpen Leonard és mtsai (2003) meghatározták az NGC 1637 távolságát a benne található cefeida változócsillagok segítségével,

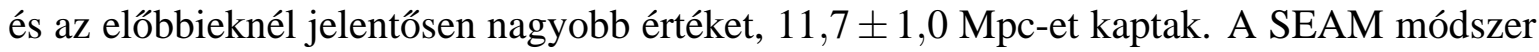
használata Baron és mtsai (2004) munkája során már ehhez jóval közelebbi értéket, 12,5 \pm 1,8 Mpc-et eredményezett. Dessart \& Hillier (2006) a CMFGEN modellekből mért sebességeket $\left(v_{\text {nlte }}\right)$ és a Dessart \& Hillier (2005a) által számolt, újabb korrekciós faktorokat $\left(\zeta_{\mathrm{D} 05}\right)$ használták. Így a távolság 11,5 $\pm 1,0$ Mpc-nek adódott. Egy hasonló megközelítéssel Baron és mtsai (2004) 12,2 $\pm 2,0 \mathrm{Mpc}$-et számoltak. Jones és mtsai (2009) a $\zeta_{\mathrm{E} 96}$ korrekciós faktorokkal 9,3 \pm 0,5 Mpc-et, míg $\zeta_{\mathrm{D} 05}$-val 13,9 $\pm 1,4$ Mpc távolságot kaptak.

Munkám során a $v_{\text {modell }}$ sebességek és Dessart \& Hillier (2005a) korrekciós faktorainak használatával a távolságot 12,5 \pm 1,4 Mpc nagyságúnak határoztam meg (Takáts \& Vinkó, 2012). Ez jól egyezik a cefeida-távolsággal, a SEAM módszerrel kapottal, és azzal amit Dessart \& Hillier (2006) kapott $v_{\text {nlte }}$ felhasználásával. Amikor viszont csak annyi változtatást tettem, hogy a sebességeket a $v_{\mathrm{Fe}}$ értékekre cseréltem, a távolság 9,7 $\pm 0,8 \mathrm{Mpc}$-re csökkent. 


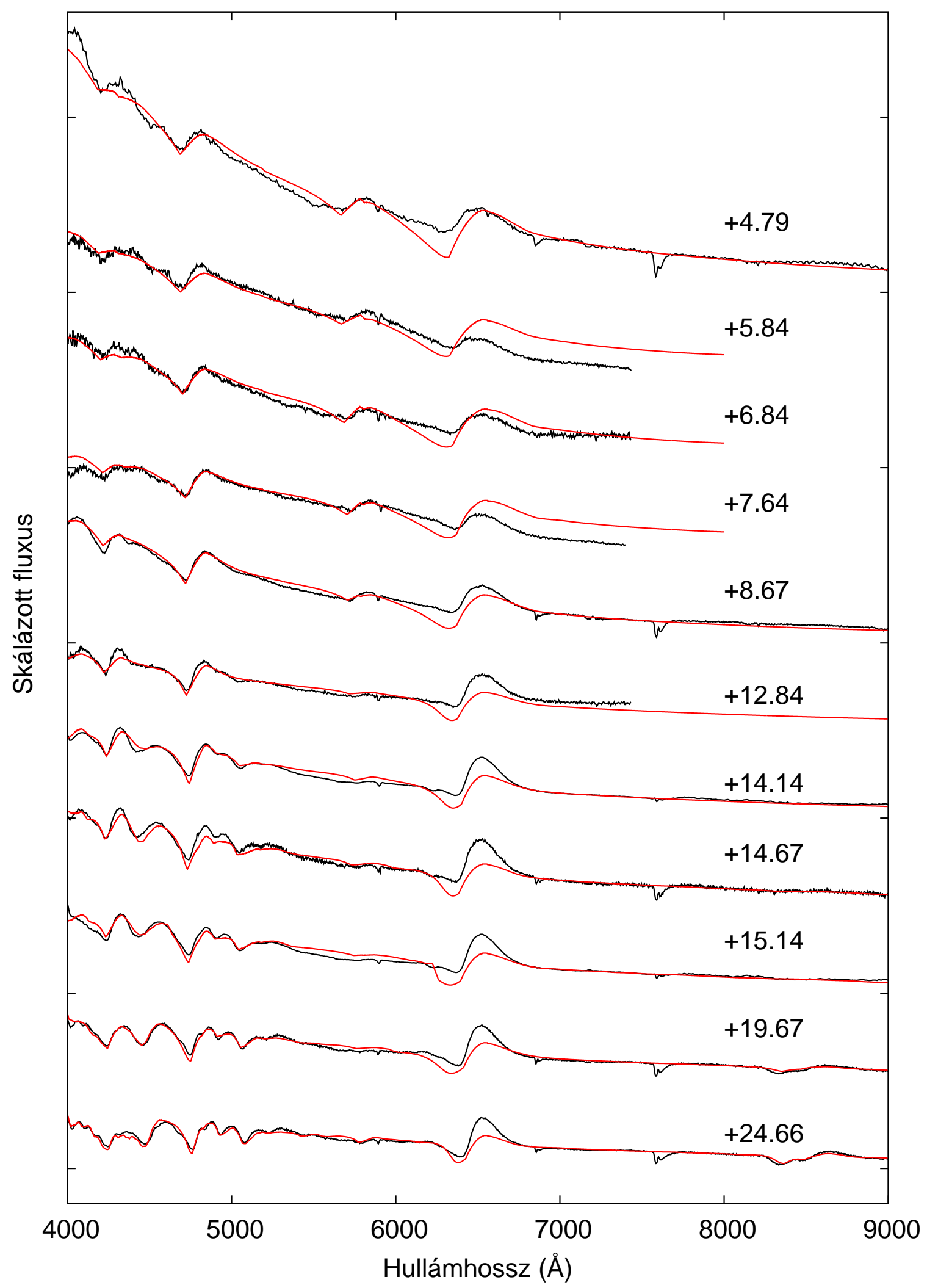

4.2. ábra. Az SN 1999em spektrumai és a rájuk illesztett modellek. 


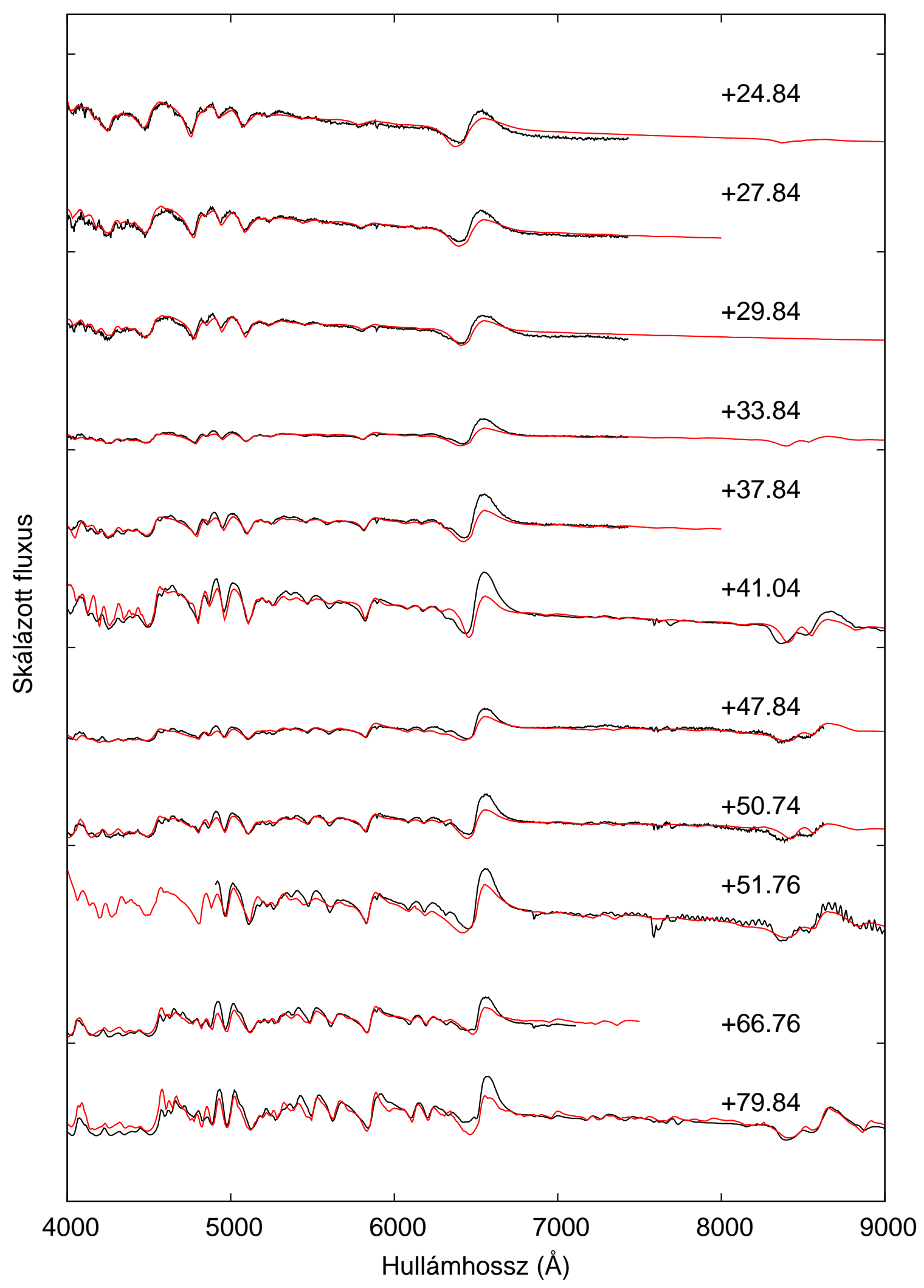

4.3. ábra. Az SN 1999em spektrumai és a rájuk illesztett modellek - folytatás. 
4.3. táblázat. Az SN 1999em és galaxisának, az NGC 1637-nek a különböző módszerekkel meghatározott távolsága.

\begin{tabular}{|c|c|c|}
\hline Módszer & Távolság (Mpc) & Referencia \\
\hline Tully-Fisher & $8,9(1,5)$ & Tully (1988) \\
\hline SN 1999em, EPM, $\zeta_{\mathrm{E} 96}$ & $7,8(0,5)$ & Hamuy (2001) \\
\hline SN $1999 \mathrm{em}, \mathrm{EPM}, \zeta_{\mathrm{E} 96}$ & $8,2(0,6)$ & Leonard és mtsai (2002) \\
\hline SN 1999em, EPM, $\zeta_{\mathrm{E} 96}$ & $7,8(0,3)$ & Elmhamdi és mtsai (2003) \\
\hline Cefeidák & $11,7(1,0)$ & Leonard és mtsai (2003) \\
\hline SN 1999em, SEAM & $12,5(1,8)$ & Baron és mtsai (2004) \\
\hline SN 1999em, EPM, $\zeta_{\mathrm{D} 05}$ & $11,5(1,0)$ & Dessart \& Hillier (2006) \\
\hline SN 1999em, EPM & $12,2(2,0)$ & Baron és mtsai (2004) \\
\hline SN 1999em, EPM, $\zeta_{\mathrm{E} 96}$ & $9,3(0,5)$ & Jones és mtsai (2009) \\
\hline SN 1999em, EPM, $\zeta_{\mathrm{D} 05}$ & $13,9(1,4)$ & Jones és mtsai (2009) \\
\hline $\mathrm{SN} 1999 \mathrm{em}, \mathrm{EPM}, \zeta_{\mathrm{D} 05}, v_{\mathrm{Fe}}$ & $9,7(0,8)$ & Takáts \& Vinkó (2012) \\
\hline SN 1999em, EPM, $\zeta_{\mathrm{D} 05}, v_{\text {modell }}$ & $12,5(1,4)$ & Takáts \& Vinkó (2012) \\
\hline
\end{tabular}

\subsection{SN 2004dj}

Az SN 2004dj az NGC 2403 jelú galaxis egy fiatal, nagy tömegú halmazában a Sandage96-ben jelent meg. 2004. július 31-én fedezte fel Itagaki (Nakano és mtsai, 2004), körülbelül 1 hónappal felrobbanása után. Kb. 3,5 Mpc-es távolságával az utóbbi évek egyik legközelebbi szupernóvája volt.

Vinkó és mtsai (2006) vizsgálatai szerint robbanás során $0,02 \pm 0,01 \mathrm{M}_{\odot}$-nyi ${ }^{56} \mathrm{Ni}$ keletkezett, a robbanás energiája $0,86_{-0,49}^{+0,89} \mathrm{erg}$, a ledobódott burok tömege pedig $19_{-10}^{+20} \mathrm{M}_{\odot}$ nagyságú lehetett. Vinkó és mtsai (2009) a szupernóva elhalványodása után tanulmányozták a Sandage-96 halmazt. Az ebben található csillagok kora alapján azt találták, hogy az SN szülő́csillagának tömege valószínúleg egy $12-20 \mathrm{M}_{\odot}$ között volt, bár egy kisebb tömegú szülő́csillag sem zárható ki.

Szalai és mtsai (2011) a Spitzer Space Telescope adatait vizsgálták, amelyek közepes infravörös tartományban készültek a robbanás utáni 98. és 1381. nap között. Sikerült kimutatniuk mind meleg $(T \sim 500 \mathrm{~K})$, mind hideg $(T \sim 100 \mathrm{~K})$ por jelenlétét, ami a robbanás után keletkezett a szupernóva körül (ld. még Meikle és mtsai, 2011).

\subsubsection{Spektrummodellezés és sebességmérés}

A rendelkezésre álló spektrumokat Vinkó és mtsai (2006) publikálták. Mivel a mérések során nem készültek képek spektrofotometriai standard csillagokról, ezért a spektrumok fluxuskalibrációja nem volt tökéletes. Ám mivel ebben az esetben a sebességek meghatározása volt a cél, ez nem befolyásolta lényegesen az eredményeket. A felhasznált 12 spektrum a robbanás utáni 47. és 100. nap között készült.

A legelső spektrum a viszonylag késői fázis miatt már tartalmaz erős fémvonalakat. A modellezés során a H I, Na I, Si I, Si II, Sc II, Ti II, Fe II, Ba II vonalait mutattam ki. A modellés az észlelt spektrumok együtt a 4.5. ábrán láthatók, míg a modellek legfőbb paramétereit 
4.4. táblázat. Az SN 2004dj különböző módszerekkel kapott tágulási sebessége.

\begin{tabular}{cccccc}
\hline \hline $\begin{array}{c}\text { fázis } \\
\text { (nap) }\end{array}$ & $\begin{array}{c}v_{\text {modell }} \\
\left(\mathrm{kms}^{-1}\right)\end{array}$ & $\begin{array}{c}v_{\mathrm{H} \beta} \\
\left(\mathrm{kms}^{-1}\right)\end{array}$ & $\begin{array}{c}v_{\mathrm{Fe}} \\
\left(\mathrm{kms}^{-1}\right)\end{array}$ & $\begin{array}{c}v_{\mathrm{cc} \# 1} \\
\left(\mathrm{kms}^{-1}\right)\end{array}$ & $\begin{array}{c}v_{\mathrm{cc \# 2}} \\
\left(\mathrm{kms}^{-1}\right)\end{array}$ \\
\hline 47,89 & $3350(300)$ & $4569(300)$ & $3183(300)$ & $3154(40)$ & $3471(83)$ \\
50,59 & $2750(150)$ & $4089(250)$ & $2920(250)$ & $2943(63)$ & $3401(172)$ \\
52,89 & $2900(150)$ & $4122(250)$ & $2949(250)$ & $3075(75)$ & $3243(115)$ \\
55,89 & $2650(100)$ & $3849(200)$ & $2897(200)$ & $2967(72)$ & $3124(122)$ \\
64,86 & $2500(150)$ & $3317(200)$ & $2625(200)$ & $2672(45)$ & $2887(114)$ \\
65,85 & $2550(100)$ & $3282(200)$ & $2573(200)$ & $2678(47)$ & $2649(106)$ \\
67,86 & $2400(150)$ & $3468(200)$ & $2645(200)$ & $2700(46)$ & $2689(118)$ \\
83,89 & $2200(200)$ & $2967(200)$ & $2350(200)$ & $2384(50)$ & $2387(114)$ \\
94,67 & $1850(250)$ & $3010(200)$ & $2101(200)$ & $2222(67)$ & $2454(145)$ \\
95,87 & $1850(200)$ & $3178(200)$ & $2186(200)$ & $2302(71)$ & $2535(161)$ \\
97,87 & $1700(150)$ & $3132(200)$ & $2182(200)$ & $2270(78)$ & $2504(156)$ \\
99,86 & $1700(150)$ & $3118(200)$ & $2075(200)$ & $2208(86)$ & $2433(153)$ \\
\hline
\end{tabular}

az A.2. táblázat tartalmazza

A megállapított $v_{\text {modell }}$ sebességek $\sim 3400$ és $1700 \mathrm{kms}^{-1}$ közé esnek (4.4. ábra, 4.4. táblázat). A vonalminimumokból mért $v_{\mathrm{H} \beta}$ és $v_{\mathrm{Fe}}$ is magasabb $v_{\text {modell }}$ értékénél az összes idôpontban, az előbbi méghozzá jelentősen, kb. 1,8-szer nagyobb (4.4. ábra). Errôl az SNrôl nem készültek CMFGEN modellek. A keresztkorreláció mindkét készlet használatával hasonló eredményeket adott, az így kapott sebességek némileg magasabbak $v_{\text {modell-nél és }}$ $v_{\mathrm{Fe}}$-nél is.

\subsubsection{Távolság}

Az SN 2004dj galaxisának, az NGC 2403-nak a távolságát már több alkalommal is mérték különbözó módszerekkel. Az eredmények nagy szórást mutatnak, 2,88 és 6,43 Mpc közé esnek $\left(\mathrm{NED}^{19}\right)$, bár többségük főleg a 3,0-4,5 Mpc tartományban található (4.5. táblázat). A szupernóva távolságát Vinkó és mtsai (2006) az EPM-mel 3,66 \pm 0,30 Mpc-nek, az SCM-mel 3,50 \pm 0,20 Mpc-nek találták. Olivares és mtsai (2010) az SCM segítségével jóval nagyobb értéket, 4,28 $\pm 0,90$ Mpc-et kaptak.

Mivel ebben az esetben nem álltak rendelkezésre spektrumok az EPM alkalmazásakor figyelembe vehető első 50 napban, ezért $v_{\mathrm{Fe}}$ és $v_{\text {modell }}$ értékeit extrapoláltam a mért fénygörbe időpontjaira az (5.2) és (5.3) összefüggések felhasználásával. Az így kapott távolságok lényegében megegyeznek: az előbbivel 3,7 $\pm 0,8$, utóbbival 3,6 $\pm 0,6$ Mpc-et kaptam.

\subsection{SN 2004et}

Az NGC 6946-ban található SN 2004et jelú szupernóvát Moretti fedezte fel 2004. szeptember 27-én (Zwitter et al., 2004). Ennek a közeli SN-nek a felfedezése nagyon korai fázisban, a robbanás után kb. egy nappal történt. Sahu és mtsai (2006) valamint Maguire

\footnotetext{
${ }^{19}$ http://ned.ipac.caltech.edu/
} 


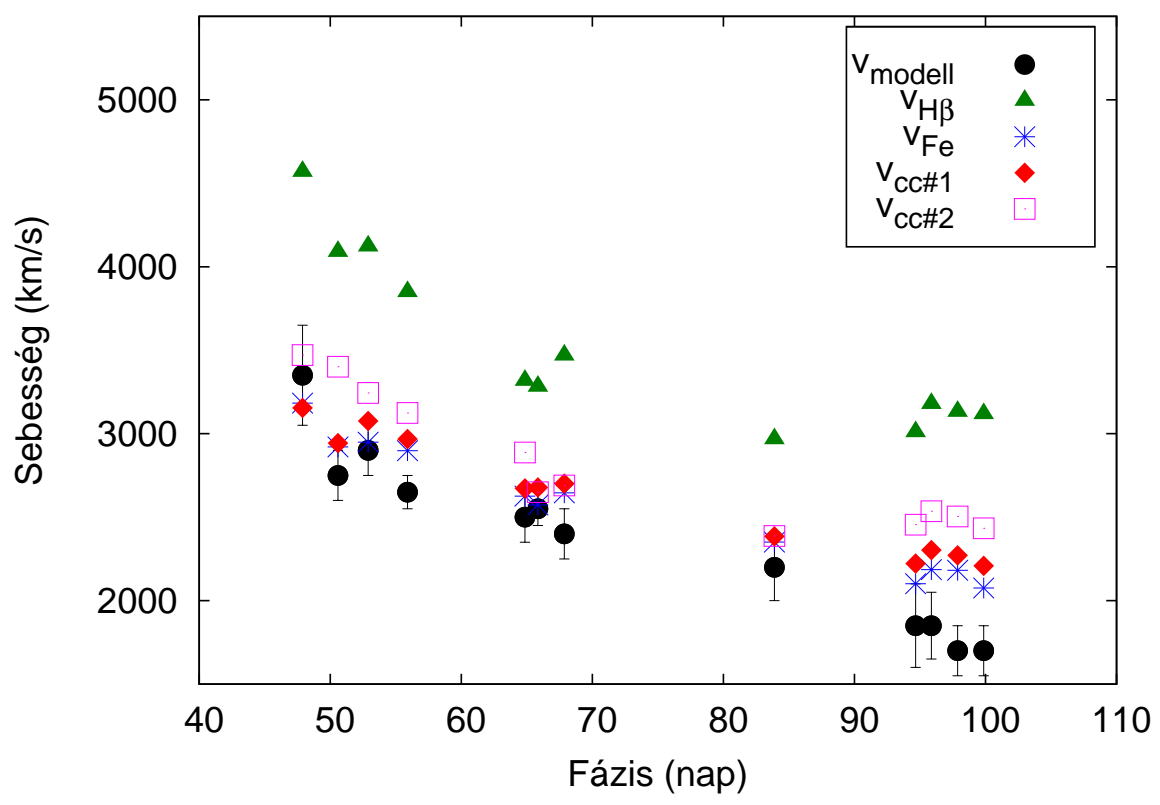

4.4. ábra. Az SN 2004dj sebességének különböző módszerekkel mért értékei.

4.5. táblázat. Az SN 2004dj és galaxisának, az NGC 2403-nak a különböző módszerekkel meghatározott távolsága.

\begin{tabular}{lcl}
\hline Módszer & Távolság (Mpc) & Referencia \\
\hline Tully-Fisher & $4,2(0,8)$ & Tully $(1988)$ \\
Tully-Fisher & $3,5(0,3)$ & Russell $(2002)$ \\
Cefeidák & $3,2(0,2)$ & Freedman és mtsai $(2001)$ \\
SN 2004dj, EPM & $3,7(0,3)$ & Vinkó és mtsai $(2006)$ \\
SN 2004dj, SCM & $3,5(0,2)$ & Vinkó és mtsai $(2006)$ \\
SN 2004dj, SCM & $4,3(0,9)$ & Olivares és mtsai $(2010)$ \\
SN 2004dj, EPM, $v_{\mathrm{Fe}}$ & $3,7(0,8)$ & Takáts \& Vinkó $(2012)$ \\
SN 2004dj, EPM, $v_{\text {modell }}$ & $3,6(0,6)$ & Takáts \& Vinkó $(2012)$ \\
\hline
\end{tabular}




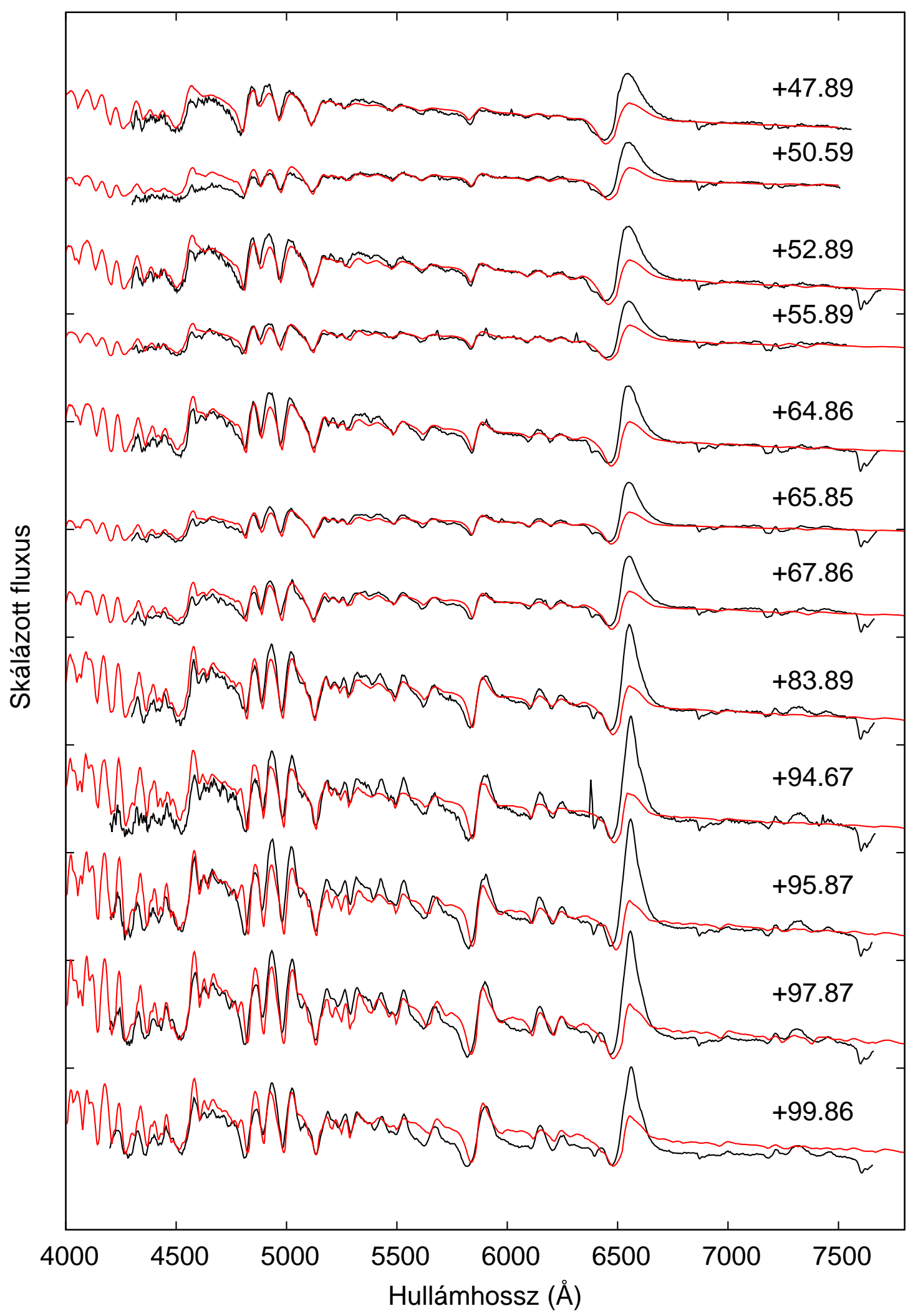

4.5. ábra. Az SN 2004dj spektrumai és a rájuk illesztett modellek. 
és mtsai (2010b) munkájának köszönhetően jó minőségú fénygörbe áll rendelkezésre, utóbbi csoport még közeli infravörös tartományban is végzett mind fotometriai, mind spektroszkópiai megfigyeléseket.

Mivel az SN felfedezése előtt alig egy nappal készült olyan felvétel, amelyen az SN pozíciójában még semmi sem látszik (Yamaoka és mtsai, 2004), a robbanás idôpontja rendkívül jól ismert, $t_{0}=2453270,5 \pm 0,5 \mathrm{JD}$ (Maguire és mtsai, 2010b).

Az SN 2004et valamivel fényesebb volt a legtöbb II-P SN-nél, a plató fázisban a luminozitása kb. másfélszerese volt az SN $1999 \mathrm{em}$ luminozitásának. A ledobott ${ }^{56} \mathrm{Ni}$ tömegét Maguire és mtsai (2010b) 0,06 $\pm 0,04 \mathrm{M}_{\odot}$-nek becsülték. A robbanás energiáját $\left(E_{\text {exp }}\right)$, a ledobódott anyag mennyiségét, valamint a szülőcsillag tömegét a különböző szerzők némileg eltérő nagyságúnak találták. Sahu és mtsai (2006) $E_{\text {exp }}=1,20_{-0,30}^{+0,38} \times 10^{51}$ erg értéket állapítottak meg, a szülőcsillag tömegére pedig $20 \mathrm{M}_{\odot}$-et kaptak. Ezzel szemben Maguire és mtsai (2010b) a robbanás energiáját némileg kisebb értéknek, $E_{\exp }=0,88 \pm 0,31 \times 10^{51}$ ergnek, a ledobódott burok tömegét pedig $14 \pm 6 \mathrm{M}_{\odot}$-nek becsülték. Utrobin \& Chugai (2009) hidrodinamikai modellek számítása során állapították meg az SN fizikai paramétereit. Eszerint a robbanás energiája a másik két cikkben kapottnál nagyobb, $E_{\exp }=2,3 \pm 0,3 \times 10^{51} \mathrm{erg}$ volt, a ledobódott burok tömege $24,5 \pm 1,0 \mathrm{M}_{\odot}$, míg a szülőcsillag tömege $M_{\text {ZAMS }}=25-29$ $\mathbf{M}_{\odot}$ nagyságú lehetett, ami szintén jóval nagyobb, mint a másik két csoport által megállapított érték. Crockett és mtsai (2011) viszont a szupernóva pozíciójáról készült archív felvételeken a valószínúsíthetô szülőcsillagot megvizsgálva azt találták, hogy annak tömege jóval kisebb, $M_{\text {ZAMS }}=8_{-1}^{+3} \mathrm{M}_{\odot}$ volt.

\subsubsection{Spektrummodellezés és sebességmérés}

Az általam használt spektrumok többségét a Sahu és mtsai (2006) valamint a Maguire és mtsai (2010b) készítették és publikálták. Az elsô 6, korai fázisban készült spektrum a 2012-es cikkünkben szerepelt először, ezek a David Dunlap Observatory 1,88 méteres teleszkópjával készültek (ld. az Appentix A-t a Takáts \& Vinkó, 2012 cikkben). A teljes minta a robbanás utáni 11. és 104. nap közötti időtartamot fedi le.

A robbanást követố elsô 17 napban készült $6 \mathrm{db}$ spektrum csak a H I és a He I vonalait tartalmazza, utóbbiak meglehetősen gyengék. A 24. napon készült spektrumban a He I 5876 Å vonal már nem azonosítható, helyén a Na I D vonala található meg. Ebben az idôpontban már a Ca II, Fe II és Ba II vonalak is megjelentek. A 30. naptól a Ti II, a 38. naptól pedig az Sc II vonalai is jelen vannak és egyre erősödnek. A spektrumok némelyike esetében az Si I és Si II jelentléte is kimutatható.

Sebességmérésre az elsô 6 korai spektrum esetében a H $\beta$ vonalat használtam, míg a későbbi spektrumok esetében az Fe II 5169 A vonalát. Az így mért $v_{\text {modell }}$ értékek 9700 és $1800 \mathrm{kms}^{-1}$ közé estek (4.6. ábra, 4.6. táblázat).

A vonalminimumokból mért $v_{\mathrm{Fe}}$ értékek általában hasonlóak $v_{\text {modell-hez, ám a két se- }}$ besség aránya némileg fázisfüggő, ugyanúgy, mint a többi SN esetében. Viszont $v_{\mathrm{H} \beta}$ értékei

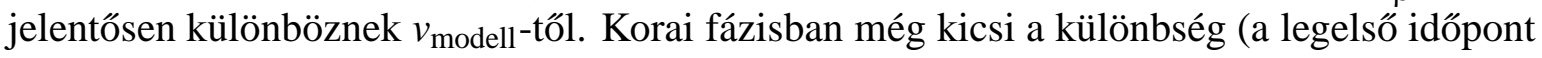
kivételével), ám a $v_{\mathrm{H} \beta} / v_{\text {modell }}$ arány gyorsan nô az idő függvényében, legmagasabb értéke $\sim 2,5$.

Az SN 2004et spektrumairól sem készültek CMFGEN modellek. Az \#1 készlettel történő keresztkorreláció esetében kapott sebességek korai fázisban $v_{\mathrm{H} \beta}$-hoz, míg késóbb $v_{\mathrm{Fe}}$-hez 
4.6. táblázat. Az SN 2004et különböző módszerekkel kapott tágulási sebessége.

\begin{tabular}{cccccc}
\hline \hline $\begin{array}{c}\text { fázis } \\
\text { (nap) }\end{array}$ & $\begin{array}{c}v_{\text {modell }} \\
\left(\mathrm{kms}^{-1}\right)\end{array}$ & $\begin{array}{c}v_{\mathrm{H} \beta} \\
\left(\mathrm{kms}^{-1}\right)\end{array}$ & $\begin{array}{c}v_{\mathrm{Fe}} \\
\left(\mathrm{kms}^{-1}\right)\end{array}$ & $\begin{array}{c}v_{\mathrm{ccH1}} \\
\left(\mathrm{kms}^{-1}\right)\end{array}$ & $\begin{array}{c}v_{\mathrm{cc \# 2}} \\
\left(\mathrm{kms}^{-1}\right)\end{array}$ \\
\hline 11,10 & $9700(450)$ & $11072(350)$ & - & $9951(153)$ & $8781(1316)$ \\
12,30 & $8900(250)$ & $8878(300)$ & - & $8605(86)$ & $8470(681)$ \\
13,00 & $9100(400)$ & $9386(350)$ & - & $9724(117)$ & $8786(1099)$ \\
14,40 & $9200(400)$ & $9375(300)$ & - & $7617(71)$ & $8570(482)$ \\
15,00 & $8800(100)$ & $8894(250)$ & - & $8635(64)$ & $8545(524)$ \\
16,40 & $8400(400)$ & $9282(300)$ & - & $9110(73)$ & $9060(545)$ \\
24,60 & $7300(550)$ & $8018(300)$ & $6416(300)$ & $6624(49)$ & - \\
30,60 & $6050(300)$ & $7487(300)$ & $5535(300)$ & $5779(56)$ & - \\
35,50 & $5500(200)$ & $7091(250)$ & $4861(250)$ & $5112(43)$ & $5739(350)$ \\
38,60 & $5100(400)$ & $6869(300)$ & $4695(300)$ & $4981(45)$ & $5513(337)$ \\
40,70 & $4600(600)$ & $6842(300)$ & $4644(300)$ & $4943(41)$ & $5448(256)$ \\
50,50 & $3750(300)$ & $5859(300)$ & $4040(300)$ & $4236(49)$ & $4252(367)$ \\
54,00 & $4050(200)$ & $5468(300)$ & $3715(300)$ & $3727(23)$ & $4352(244)$ \\
55,60 & $3600(450)$ & $5396(300)$ & $3686(300)$ & $3867(37)$ & $3895(408)$ \\
55,76 & $3900(250)$ & $5578(250)$ & $3840(250)$ & $4048(37)$ & $4113(228)$ \\
63,50 & $3200(400)$ & $5018(300)$ & $3539(300)$ & $3656(43)$ & $3678(349)$ \\
73,60 & $2600(450)$ & $4674(300)$ & $3292(300)$ & $3327(45)$ & $3793(217)$ \\
79,73 & $2600(100)$ & $4807(250)$ & $3133(250)$ & $3192(31)$ & $3504(246)$ \\
84,79 & $2400(200)$ & $4725(250)$ & $3147(250)$ & $3172(51)$ & $3490(257)$ \\
86,50 & $2250(200)$ & $4561(250)$ & $3060(250)$ & $2876(64)$ & $3496(148)$ \\
98,60 & $1900(450)$ & $4377(300)$ & $2740(300)$ & $2779(22)$ & $3268(131)$ \\
103,7 & $1800(150)$ & $4412(250)$ & $2779(250)$ & $2708(33)$ & $3060(201)$ \\
\hline
\end{tabular}

közelítenek. A \#2 készlet használatakor a korai fázisban hasonló eredmények születtek, ám a későbbi időpontokban az sebességek $v_{\mathrm{cc} \# 1}$-nél szisztematikusan magasabbak.

\subsubsection{Távolság}

Az NGC 6946-nak, az SN 2004et galaxisának távolságára kapott korábbi eredmények változatosak, 4,3 és 12,7 Mpc közé esnek (NED), bár a többségük 4,3-6 Mpc között szóródik (4.7. táblázat). A szupernóva távolságát Poznanski és mtsai (2009) 4,7 $\pm 0,1 \mathrm{Mpc}$-nek határozta meg SCM használatával, Olivares és mtsai (2010) ugyanezzel a módszerrel szintén 4,7 $\pm 0,7$ Mpc-et kaptak.

A Takáts \& Vinkó (2012) cikkünkben az EPM-el történő számolás szintén megerősíti ez utóbbi értékeket. Mind $v_{\text {modell }}$, mind $v_{\mathrm{Fe}}$ használata a távolságra 4,8 Mpc-et adott (4.7. táblázat). 


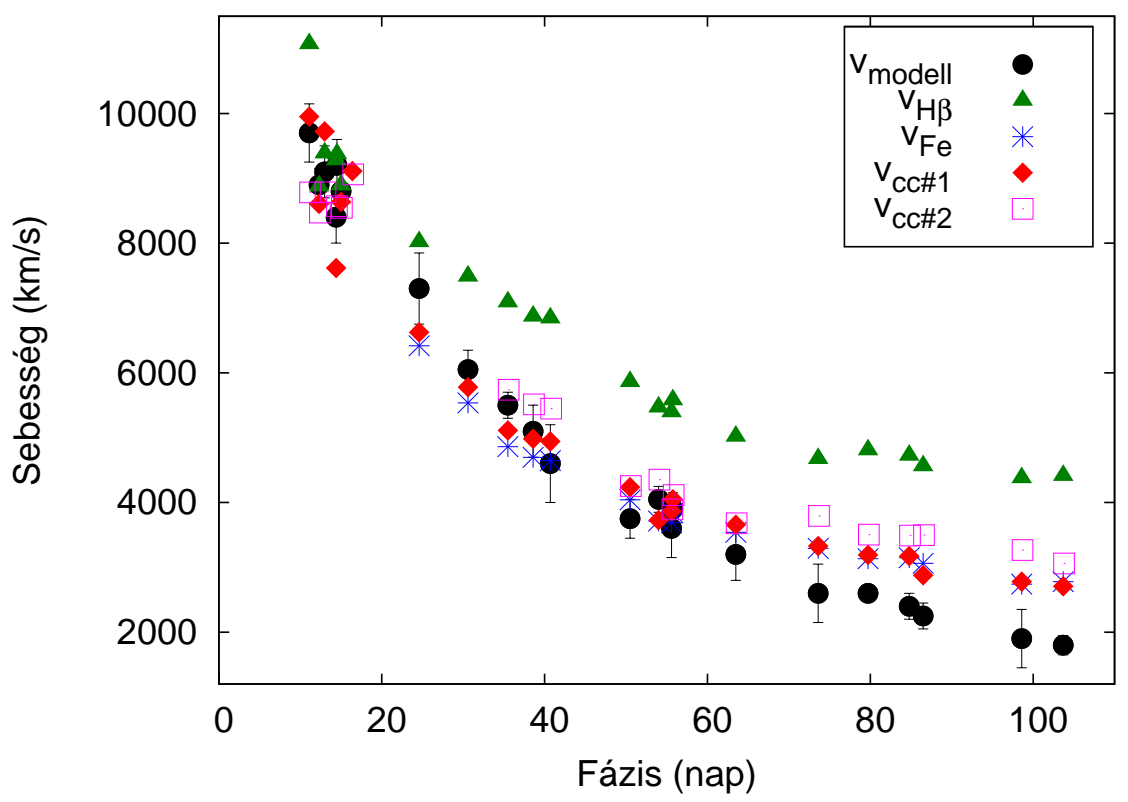

4.6. ábra. Az SN 2004et sebességének különböző módszerekkel mért értékei.

4.7. táblázat. Az SN 2004et és galaxisának, az NGC 6946-nak a különböző módszerekkel meghatározott távolsága.

\begin{tabular}{lcl}
\hline Módszer & Távolság (Mpc) & Referencia \\
\hline Tully-Fisher & $5,5(1,1)$ & Tully $(1988)$ \\
SN 1980K, EPM & $5,7(0,7)$ & Schmidt és mtsai (1994b) \\
PNLF $^{a}$ & $6,1(0,6)$ & Herrmann és mtsai (2008) \\
SN 2002hh, SCM & $6,0(0,6)$ & Poznanski és mtsai (2009) \\
SN 2004et, SCM & $4,7(0,1)$ & Poznanski és mtsai (2009) \\
SN 2004et, SCM & $4,7(0,7)$ & Olivares és mtsai (2010) \\
SN 2004et, EPM, $v_{\mathrm{Fe}}$ & $4,8(0,6)$ & Takáts \& Vinkó (2012) \\
SN 2004et, EPM, $v_{\text {modell }}$ & $4,8(0,4)$ & Takáts \& Vinkó $(2012)$ \\
\hline
\end{tabular}

${ }^{a}$ Planetáris ködök luminozitásfüggvénye (planetary nebula luminosity function) 


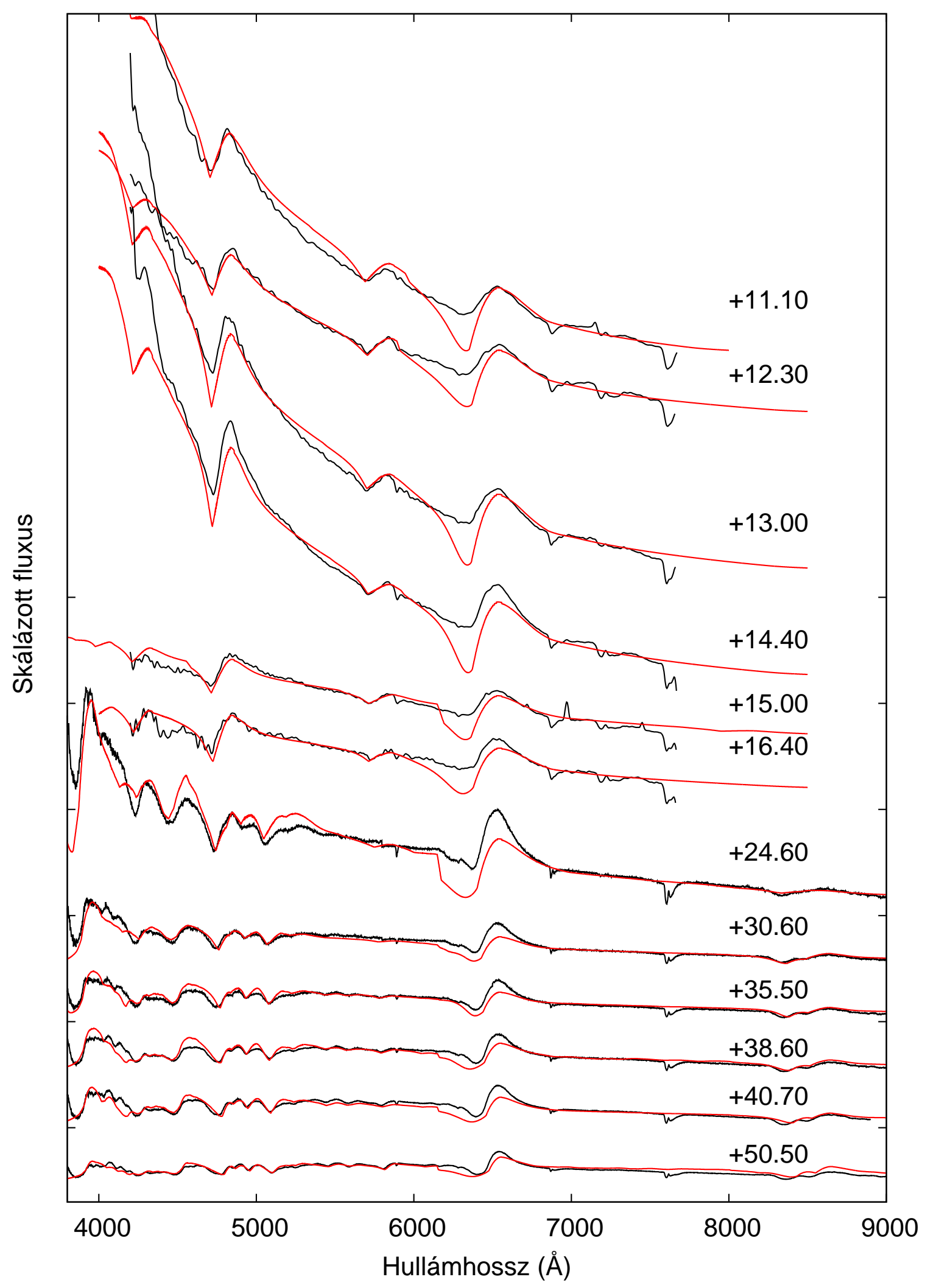

4.7. ábra. Az SN 2004et spektrumai és a rájuk illesztett modellek. 


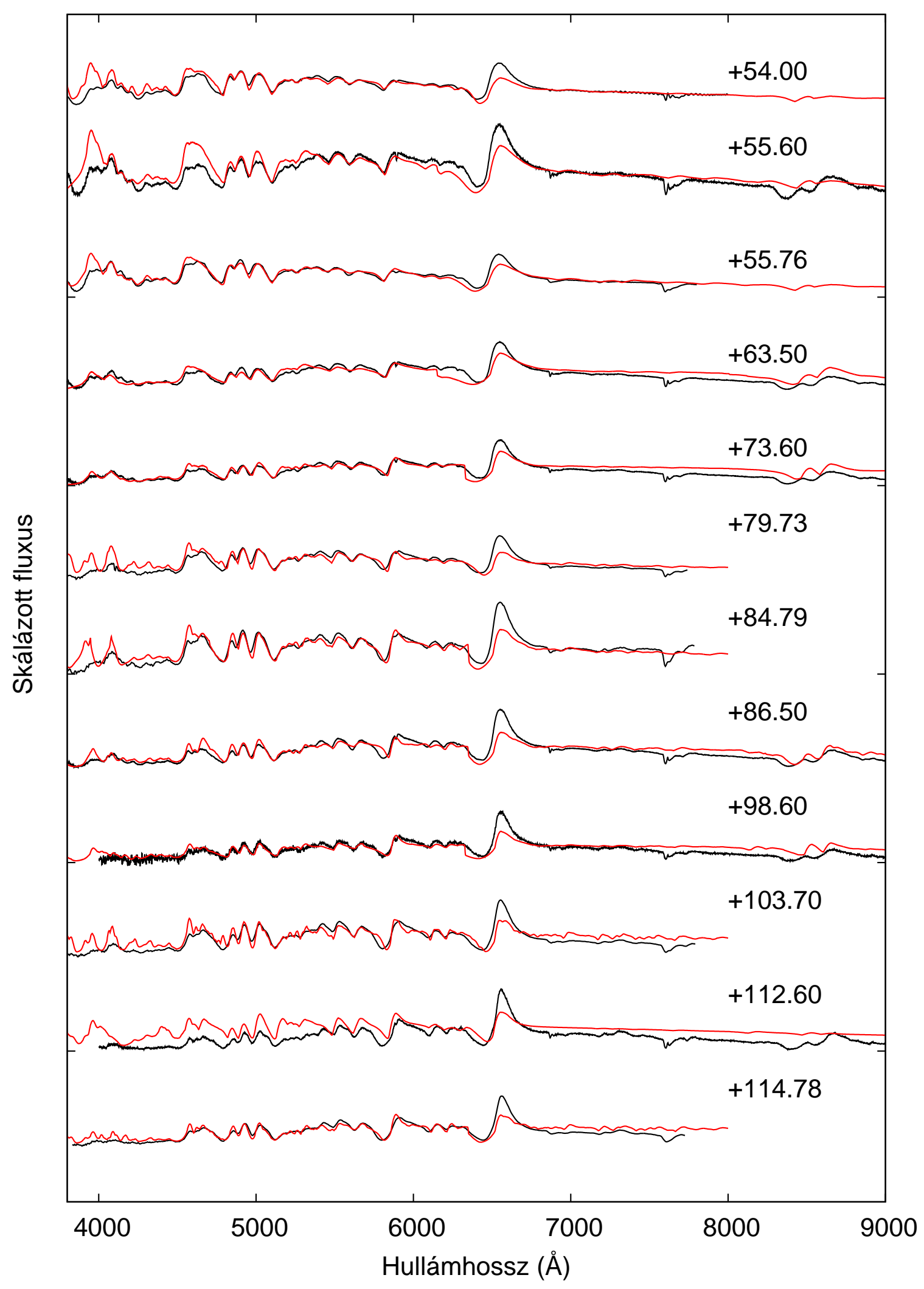

4.8. ábra. Az SN 2004et spektrumai és a rájuk illesztett modellek - folytatás. 


\subsection{SN 2005cs}

Az SN 2005cs-t Kloehr és mtsai (2005) fedezték fel 2005. június 29-én az M 51-ben. Korai felfedezésének és közelségének köszönhetően rendkívül részletes és jó minőségú észlelések készültek róla. Pastorello és mtsai (2006) UBVRI szürős fotometriai, valamint spektroszkópiai méréseket közöltek a robbanást követô elsô egy hónapot lefedve. Ezen adatok, valamint korai, amatôr csillagászok által végzett észlelések segítségével ráadásul sikerült a robbanás időpontját nagyon pontosan meghatározniuk, mely a $t_{0}=2453549,0 \pm 1,0 \mathrm{JD}$ (2005. június 27.5 UT) időpontban következett be.

A szupernóva fejlődését Pastorello és mtsai (2009) valamint Tsvetkov és mtsai (2006) is figyelemmel követték, fotometriai észleléseik együttesen 400 napot fednek le nagyon részletesen. Az SN2005cs jelentôsen halványabb a legtöbb II-P szupernóvánál, luminozitása kb. 6-8-szor kisebb, mint a tipikusnak tekinthető SN 1999em fényessége (1.9 ábra).

Archív HST felvételek vizsgálatával a szülőcsillag tömegét Li és mtsai (2006) valamint Maund és mtsai (2005) is ugyanakkorának becsülték, elóbbi csoport $M_{\text {ZAMS }}=10 \pm 3 \mathrm{M}_{\odot}$ nagyságot, utóbbi $M_{\mathrm{ZAMS}}=9_{-2}^{+3} \mathrm{M}_{\odot}$ értéket határozott meg.

Pastorello és mtsai (2006) adatainak felhasználásával a megmértem ennek a szupernóvának a távolságát (ld. lentebb), és ennek felhasználásával néhány fontosabb fizikai paraméterét is meghatároztam (Takáts \& Vinkó, 2006). A Hamuy (2003) által megállapított, a plató közepén mért $V$ szứốs abszolút magnitúdó és a robbanás során keletkezett ${ }^{56} \mathrm{Ni}$ tömege közt talált korreláció alkalmazásával azt kaptam, hogy a keletekezett ${ }^{56} \mathrm{Ni}$ tömege $\sim 0,009 \pm 0,003 \mathrm{M}_{\odot}$ volt. Nadyozhin (2003) egyenletei - a Litvinova \& Nadezhin (1985) által számolt hidrodinamikai modellek alapján - a szupernóva abszolút fényességének, tágulási sebességének és a plató hosszának ismeretében megadják a robbanás energiáját, a ledobódott burok tömegét és a csillag kezdeti sugarának nagyságát. Az SN 2005cs esetében ezeket a paramétereket $E_{\mathrm{exp}}=0,19_{-0,10}^{+0,17} \times 10^{51} \mathrm{erg}, M_{\mathrm{ej}}=8,3_{-4,0}^{+6,8} \mathrm{M}_{\odot}$ és $R_{\mathrm{ini}}=177_{-100}^{+258} \mathrm{R}_{\odot}$ nagyságúnak határoztam meg.

Utrobin \& Chugai (2008) hidrodinamikai modellezéssel ezektôl némileg eltérô értékeket kaptak. Ők a szülő́csillag tömegét $M_{\text {ZAMS }}=18,2 \pm 1,0 \mathrm{M}_{\odot}$ nagyságúnak határozták meg, amely nagyobb mind a direkt észleléssel, mind a közvetett meghatározással kapottaknál. Számításaik szerint a robbanás energiája $E_{\exp }=0,41 \pm 0,03 \times 10^{51} \mathrm{erg}$ volt, a csillag sugara robbanás előtt $R_{\text {ini }}=600 \pm 140 \mathrm{R}_{\odot}$, a keletkezett ${ }^{56} \mathrm{Ni}$ tömege pedig $0,0082 \pm 0,0016 \mathrm{M}_{\odot}$, ami jól egyezik az általam kapott értékkel.

\subsubsection{Spektrummodellezés és sebességmérés}

A modellezés során felhasznált spektrumok Pastorello és mtsai 2006-os és 2009-es cikkeiból származnak. A $14 \mathrm{db}$ spektrum a robbanást követő 3. és 61. nap közötti idôszakot fedi le.

A legkorábbi 3 spektrum esetében még nem jelentek meg fémvonalak, csak a hidrogén Balmer-sorozata, valamint a He I 5876 Å vonala látható. Mind a $\mathrm{H} \beta$, mind a He I vonal kék oldalán megfigyelhetô egy-egy gyenge vonal (4.9. ábra). Pastorello és mtsai (2006) szerint ezek vagy a hidrogén és a hélium nagy sebességú (high velocity, HV) vonalai lehetnek, vagy egy másik elemhez (N II vagy Si II) tartoznak. HV vonalak megjelenését okozhatja például egy külsô, nagyobb sebességú, héliumban gazdag réteg jelenléte. Ugyanakkor Pas- 
4.8. táblázat. Az SN 2005cs különböző módszerekkel kapott tágulási sebessége.

\begin{tabular}{cccccc}
\hline \hline $\begin{array}{c}\text { fázis } \\
\text { (nap) }\end{array}$ & $\begin{array}{c}v_{\text {modell }} \\
\left(\mathrm{kms}^{-1}\right)\end{array}$ & $\begin{array}{c}v_{\mathrm{H} \beta} \\
\left(\mathrm{kms}^{-1}\right)\end{array}$ & $\begin{array}{c}v_{\mathrm{Fe}} \\
\left(\mathrm{kms}^{-1}\right)\end{array}$ & $\begin{array}{c}v_{\mathrm{cc \# 1}} \\
\left(\mathrm{kms}^{-1}\right)\end{array}$ & $\begin{array}{c}v_{\mathrm{cc \# 2}} \\
\left(\mathrm{kms}^{-1}\right)\end{array}$ \\
\hline 3,44 & $7100(200)$ & $7275(300)$ & - & $17105(1876)$ & $30045(365)$ \\
4,41 & $6900(150)$ & $6848(250)$ & $6814(250)$ & $7703(109)$ & $7092(705)$ \\
5,39 & $6500(250)$ & $6487(300)$ & $6418(300)$ & $7594(151)$ & $6945(586)$ \\
8,43 & $5900(300)$ & $6050(300)$ & $5481(300)$ & $5745(143)$ & $5775(71)$ \\
8,84 & $5950(100)$ & - & $5222(250)$ & $5422(209)$ & $4337(193)$ \\
14,36 & $4150(300)$ & $5052(300)$ & $4167(300)$ & $4060(52)$ & $4119(80)$ \\
14,44 & $4600(100)$ & $5099(250)$ & $4213(250)$ & $3908(43)$ & $4591(170)$ \\
17,35 & $4150(50)$ & $4532(250)$ & $3763(250)$ & $3616(49)$ & $3757(129)$ \\
18,42 & $4150(100)$ & $4345(250)$ & $3788(250)$ & $3566(58)$ & $3742(110)$ \\
22,45 & $3550(300)$ & $4069(300)$ & $3049(300)$ & $3232(51)$ & $3765(315)$ \\
34,44 & $1900(50)$ & $2222(200)$ & $2318(200)$ & $2254(19)$ & $2505(126)$ \\
36,40 & $1800(100)$ & $2003(200)$ & $2142(200)$ & $2189(38)$ & $2202(74)$ \\
44,40 & $1350(50)$ & - & $1756(200)$ & $1907(23)$ & $2036(182)$ \\
61,40 & $1050(50)$ & - & $1311(200)$ & $1459(24)$ & $1611(274)$ \\
\hline
\end{tabular}

torello és mtsai (2006) azt is megmutatták, hogy ha ezek HV vonalak, akkor a hozzájuk tartozó sebességek minden esetben jelentősen különbözők (ld. az 5. ábrájukat), ezért azt valószínúsítették, hogy inkább más ionok vonalairól van szó. Ugyanerre a következtetésre jutottak Dessart és mtsai (2008) is, akik a CMFGEN kód használatával az N II jelenlétét mutatták ki. A SYNOW-val történő modellezés során ezeket a gyenge vonalakat én is jól tudtam illeszteni az N II és Si II ionok figyelembevételével (4.9. ábra). A H $\beta$ mellett a N II $4623 \AA$, a He I mellett a N II 5679 Å, míg a H $\alpha$ mellett pedig az Si II 6355 Å hullámhosszú vonala található meg.

A robbanás utáni 9. naptól kezdenek az Fe II, Sc II és a Ba II vonalai megjelenni. A 15. naptól kezdve már az O I, Na I, Mg I, Ca II, Sc II és Ti II jelenléte is kitmutatható, ugyanakkor a He I a 18. naptól teljesen eltúnik.

A sebesség mérésére az első három spektrum esetében a $\mathrm{H} \beta$ vonalat kellett használni, a késốbbi spektrumoknál már a Fe II 5169 Å is elég erôs volt. A fotoszferikus sebességek jóval alacsonyabbak, mint a többi SN esetében, 7100 és $1100 \mathrm{kms}^{-1}$ közé esnek, annak ellenére, hogy meglehetôsen korai, a robbanást követő 3. és 61. nap közötti időszakot fedik le.

Az abszorpciós minimum Doppler-eltolódásából meghatározott sebességek nem különböznek jelentősen $v_{\text {modell }}$-tôl. A $v_{\mathrm{Fe}}$ értékei követik a többi SN esetében is megfigyelhető

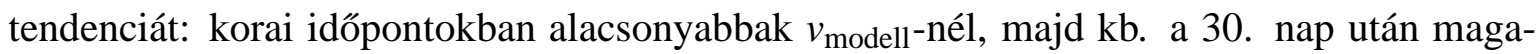
sabbakká válnak annál. A $v_{\mathrm{H} \beta}$ értékei ebben az esetben sokkal kevésbé térnek el $v_{\text {modell-tôll, }}$ mint a másik 4 SN esetében, és a két sebesség aránya is végig nagyjából állandó marad (4.8. ábra).

A Dessart és mtsai (2008) által a CMFGEN modellezés során kapott sebességek nagyon hasonlóak $v_{\text {modell }}$-hez mindegyik spektrum esetében, kivéve azt az egyet, amelyik a robbanást követő 9. napon készült. A keresztkorreláció során kapott sebességek mindkét templatekészlet esetében $v_{\mathrm{Fe}}$-hez hasonló eredményeket szolgáltattak (4.8.ábra). 


\subsubsection{Távolság}

A galaxis távolságát korábban már több módszerrel is meghatározták (4.10. táblázat), az értékek a 6 és 9 Mpc közötti tartományban szóródnak. Az ebben a galaxisban felbukkant korábbi szupernóva, az SN 1994I is felhasználható volt erre a célra, a SEAM alkalmazásával Iwamoto és mtsai (1994) 6,9 \pm 1,0 Mpc-et, míg Baron és mtsai (1996) 6,0 $\pm 1,9$ Mpc-et kaptak. Baron és mtsai (2007) a PHOENIX spektrummodellező kód és a SEAM módszer felhasználásával számolták ki az SN 2005cs távolságát, és $D=7,9_{-0,6}^{+0,7} \mathrm{Mpc}$-et kaptak. Dessart és mtsai (2008) az SN 2005cs távolságát kétféle megközelítéssel is meghatározták. Egyrészt alkalmazták az EPM-et, felhasználva azokat a sebességeket, amelyeket a CMFGEN modellezés során kaptak. Másrészt a készített spektrummodellek segítségével használták a SEAM-ot is. A két módszer nagyon hasonló eredményt adott, végeredményként a szerzők a $D=8,9 \pm 0,5 \mathrm{Mpc}$ távolságot kapták.

Az SN 2005cs távolságmeghatározásával két publikációban is foglalkoztam. A Takáts \& Vinkó (2006) cikkben először az EPM bolometrikus fluxust használó változatát (ld. 2.14. fej.) alkalmaztam. Az adatok Pastorello és mtsai (2006) cikkéből származtak.

A $B V R I$ szűrős magnitudókat először vörösödésre korrigáltam - amelyet ekkor Pastorello és mtsai (2006) munkájának alapján $E(B-V)=0,11$-nek vettem - majd fluxusokká $\left(f_{\lambda}\right)$ konvertáltam őket. A bolometrikus fluxust ezekből a szúrők effektív hullámhosszának és félértékszélességének figyelembevételével az $f_{\lambda}$ értékek összeintegrálásával számoltam ki. A hullámhossztartomány kék és vörös szélét úgy vettem figyelembe, hogy a fluxusokat lineárisan extrapoláltam $f_{B}$ és $f_{I}$ értékeiből, a fluxust 3400 és 23000 Å-nél nullának feltételezve.

A tágulási sebességek ekkor szintén Pastorello és mtsai (2006) cikkéből származtak, a korai időpontokban a He I 5876 Å vonalból, késôbb az Fe II 5169 Å vonalból általuk mért értékeket interpoláltam a fotometriai adatok időpontjaira. A távolságmeghatározás során a Dessart \& Hillier (2005a) korrekciós faktorait használtam.

Mivel az SN 2005cs robbanásának időpontja kivételesen jól ismert, ezért (2.4) egyenlet illesztése során a $t_{0}$ paramétert fixen tartottam. Így a szupernóva távolságaként $D=$ $8,34 \pm 0,30 \mathrm{Mpc}$-et kaptam. Abban az esetben, amikor a $t_{0}$ is illesztési paraméter volt, a távolság jelentősen kisebb lett, $D=6,84 \pm 0,18 \mathrm{Mpc}$. Ekkor a robbanás időpontjának $t_{0}=2453553,39 \pm 0,52$ JD-t kaptam, amely kb. 4 nappal későbbi, mint a Pastorello és mtsai (2006) által meghatározott, ráadásul 2 nappal későbbi, mint a felfedezés dátuma. A szupernóva EPM távolságaként a két eredmény átlagát, $D_{E P M}=7,59 \pm 1,02 \mathrm{Mpc}$-et fogadtam el.

Kipróbáltam azt is, hogy Eastman és mtsai (1996) által meghatározott korrekciós faktorok használata mennyiben módosítja az eredményeket. Ekkor - a vártnak megfelelően - jelentősen kisebb távolságokat kaptam: rögzített $t_{0}$ esetén $D=6,37 \pm 0,12$, illesztett $t_{0^{-}}$ lal pedig $D=5,40 \pm 0,13$ lett a távolság, és az utóbbi esetben a robbanás idôpontjára $t_{0}=$ 2453553,8 \pm 0,4 JD adódott. Ezek a távolságértékek az M51 minden korábbi, más módszerrel kapott távolságánál jelentősen kisebbek (4.10. táblázat).

Ez a közeli, jól észlelt szupernóva lehetőséget adott az SCM tesztelésére is. A cikk írásakor, 2006-ban ez a módszer még meglehetősen új volt, ráadásul kalibrációja során Hamuy (2005) mindössze 24 SN-t használt, amelyek közül csak egy, SN 1999br volt alacsony luminozitású. Ezt a mintát Nugent és mtsai (2006) még két objektummal egészítették 


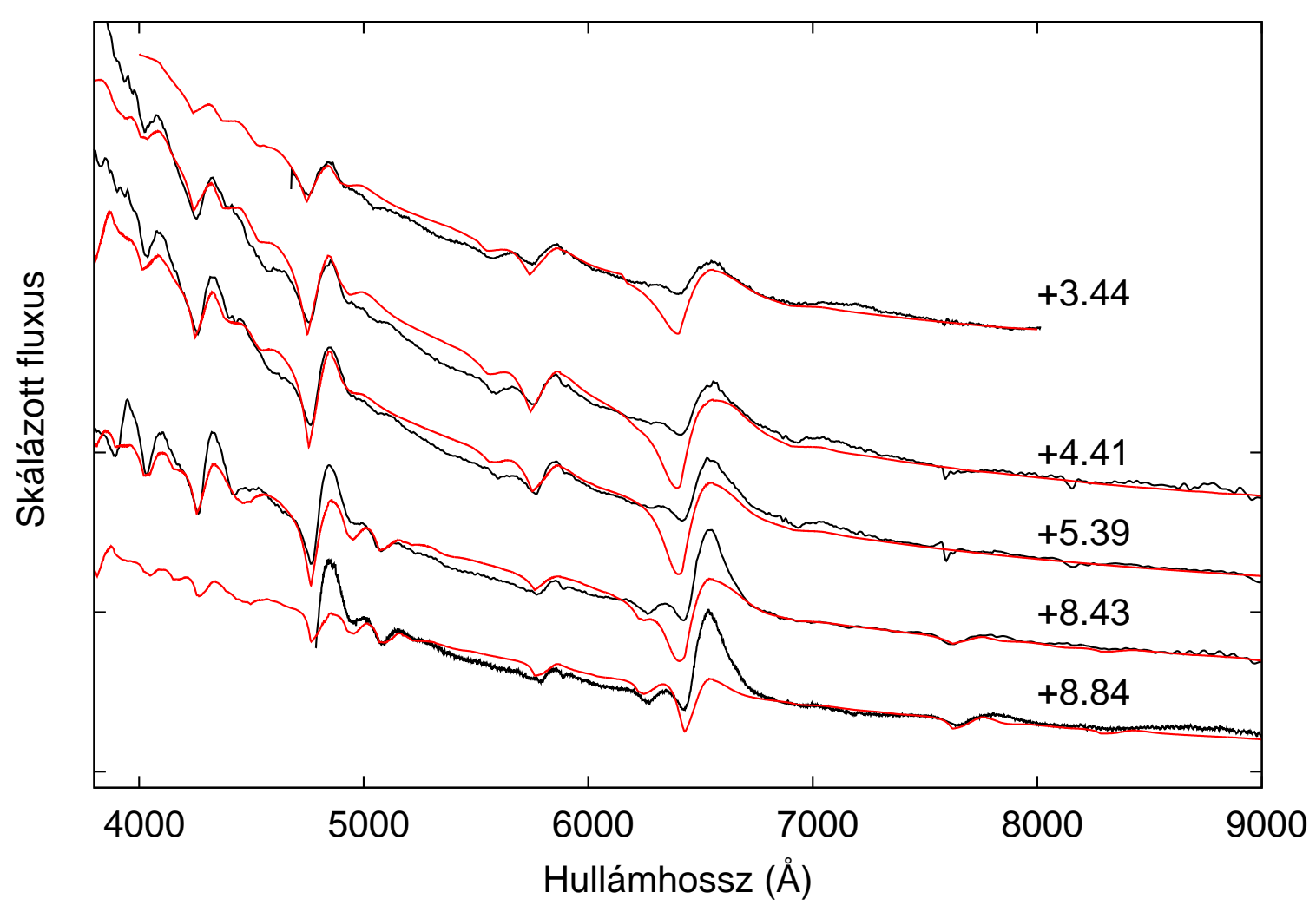

4.9. ábra. Az SN 2005cs spektrumai és a rájuk illesztett modellek.

ki.

A Takáts \& Vinkó (2006) cikkben az SCM kétféle alkalmazására került sor. Először Hamuy (2005) kalibrációját használtam. A robbanás utáni 50. napon a fényességet - interpoláció alkalmazásával $-V(50 \mathrm{~d})=14,69 \pm 0,10$ valamint $I(50 \mathrm{~d})=13,96 \pm 0,10$ magnitúdónak állapítottam meg. Ekkor még nem álltak rendelkezésre spektrumok a robbanást követő 50. nap környékéig terjedően, ezért a v(50d) megállapításához egyrészt az SN 1999br sebességgörbéjével (Hamuy, 2001) való összehasonlítást, másrészt a Nugent és mtsai (2006) által megállapított, a 2.2.2 pontban már említett összefüggést használtam a sebesség extrapolációjára. Így $v(50 \mathrm{~d})=2030 \pm 300 \mathrm{kms}^{-1}$ értéket kaptam. A távolság $D_{V}=6,13 \pm 0,80$ Mpc és $D_{I}=6,55 \pm 0,90 \mathrm{Mpc}$ lett, ami jelentősen kisebb, mint a más módszerek alkalmazása során kapottak.

Mivel a hasonló, kis fényességú SN-k közül csak egy szerepelt az SCM kalibrációjához használt korábbi mintában, előfordulhat, hogy ez volt az oka a távolság alulbecslésének. Ezért az SN 2005cs EPM-mel kapott távolságai átlagának $\left(D_{E P M}\right)$ felhasználásával kiegészítettem Hamuy (2005) és Nugent és mtsai (2006) mintáját, és újrakalibráltam az SCM-et. Az így kapott, (2.17) és (2.18) egyenletben szereplő $a$ és $b$ konstansok a 4.9. táblázatban találhatók. A táblázatban összehasonlításként a Hamuy (2005) által kapott konstansokat is feltüntettem, valamint mindegyik esetben kiszámítottam az SN 2005cs távolságát. A kalibrációm a $V$ szúrôs adatok esetében valamivel nagyobb, az I szúrô esetében pedig kisebb távolságot eredményezett, mint Hamuy (2005) konstansainak alkalmazása. 


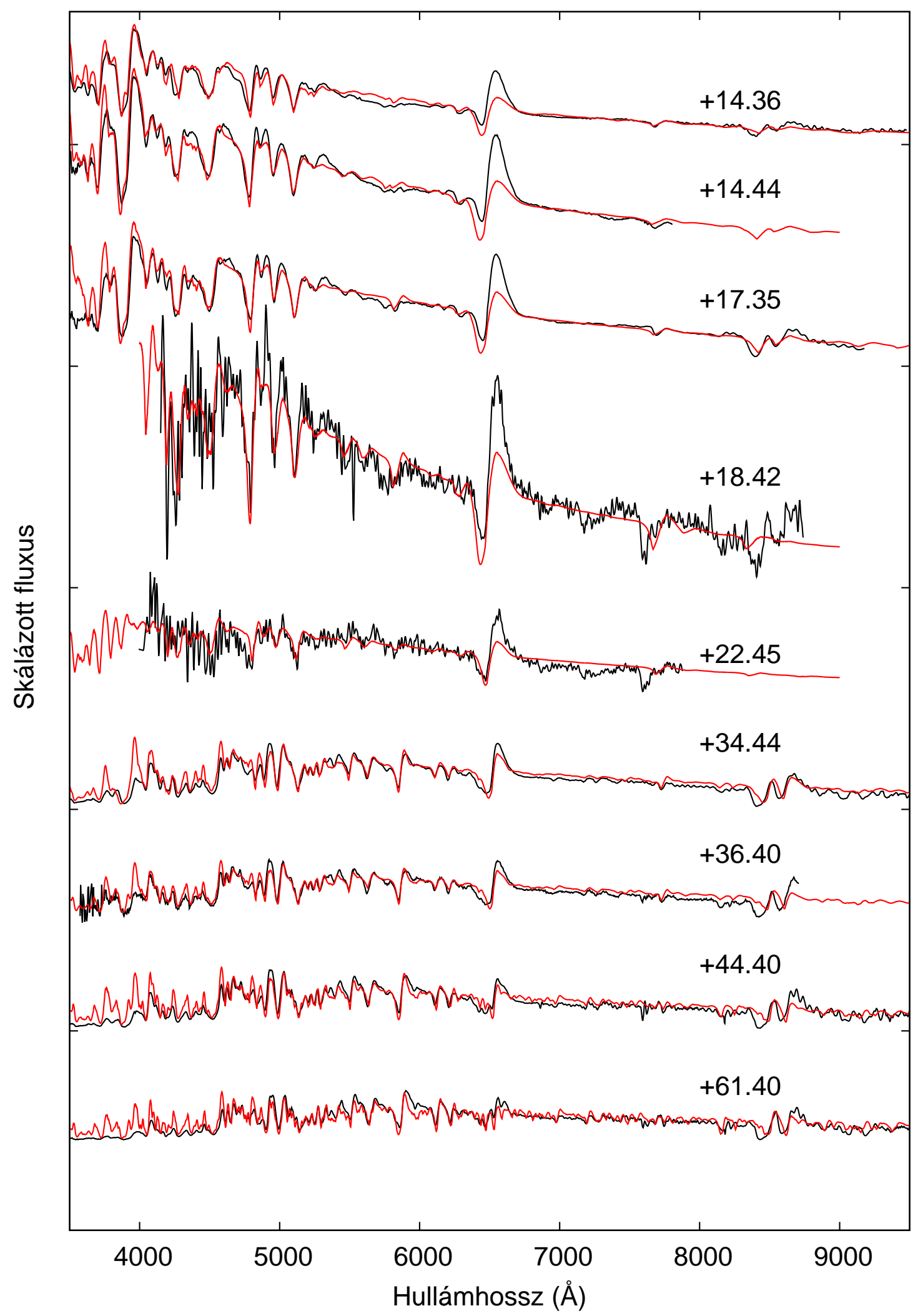

4.10. ábra. Az SN 2005cs spektrumai és a rájuk illesztett modellek - folytatás. 


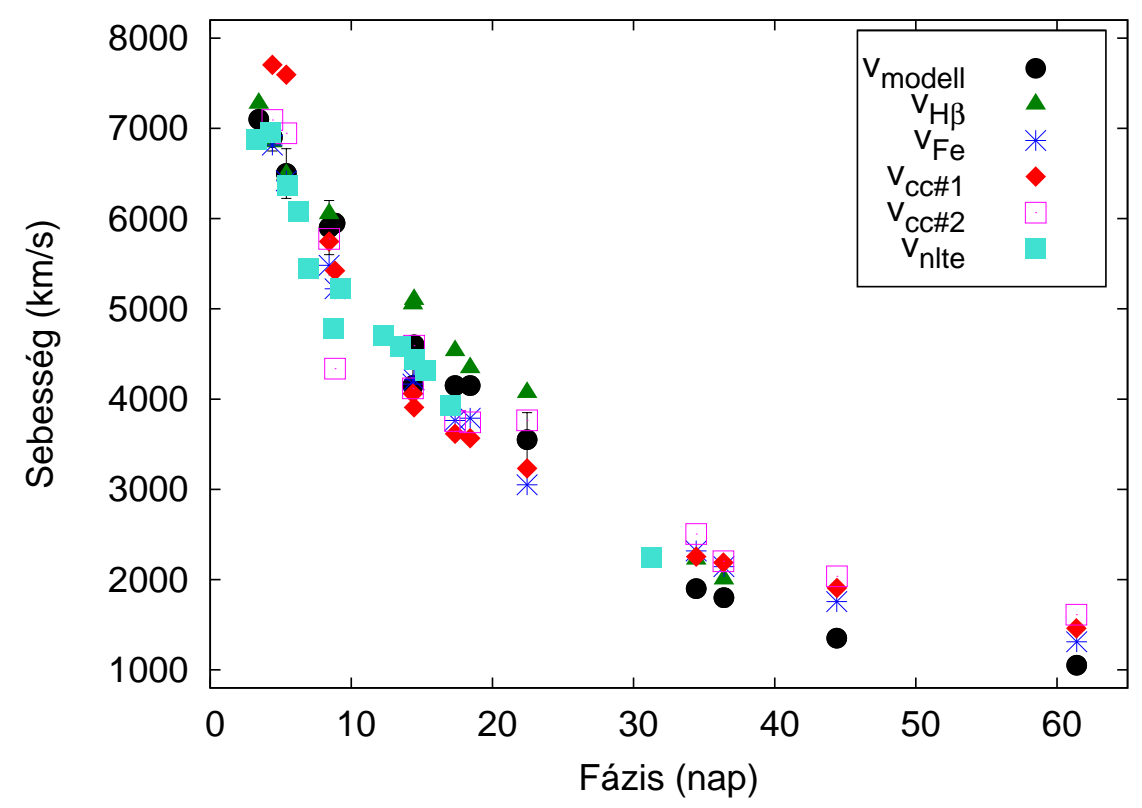

4.11. ábra. Az SN 2005cs sebességének különböző módszerekkel mért értékei.

4.9. táblázat. Az SCM kalibrációja során meghatározott, a (2.17) és (2.18) egyenletben szereplő Hamuy (2005) által meghatározott, illetve az általunk, SN 2005cs adatainak felhasználásával kapott értékei. Az utolsó oszlop az SN 2005cs ezen konstansok segítségével számolt távolságát mutatják.

\begin{tabular}{ccccc}
\hline & & $a$ & $b$ & Távolság (Mpc) \\
\hline \multirow{2}{*}{$V$} & Hamuy (2005) & $6,564(0,880)$ & $1,478(0,110)$ & $6,13(0,80)$ \\
& Takáts \& Vinkó (2006) & $6,193(0,570)$ & $1,407(0,080)$ & $6,35(1,30)$ \\
& & & & \\
\multirow{2}{*}{$I$} & Hamuy (2005) & $5,869(0,680)$ & $1,926(0,090)$ & $6,55(0,90)$ \\
& Takáts \& Vinkó (2006) & $5,821(0,570)$ & $1,848(0,090)$ & $6,37(1,30)$ \\
\hline
\end{tabular}


4.10. táblázat. Az M51 különböző módszerekkel kapott távolsága.

\begin{tabular}{lcl}
\hline Módszer & Távolság (Mpc) & Referencia \\
\hline YSA $^{a}$ & $6,9(0,7)$ & Georgiev és mtsai (1990) \\
PNLF $^{b}$ & $7,6(0,6)$ & Ciardullo és mtsai (2002) \\
SBF $^{c}$ & $7,7(1,0)$ & Tonry és mtsai (2001) \\
SN 1994I, SEAM & $6,9(1,0)$ & Iwamoto és mtsai (1994) \\
SN 1994I, SEAM & $6,0(1,9)$ & Baron és mtsai $(1996)$ \\
SN 2005cs, EPM & $7,6(0,8)$ & Takáts \& Vinkó (2006) \\
SN 2005cs, SCM & $6,4(1,6)$ & Takáts \& Vinkó (2006) \\
SN 2005cs, SEAM & $7,9(0,7)$ & Baron és mtsai (2007) \\
SN 2005cs, EPM, SEAM & $8,9(0,5)$ & Dessart és mtsai (2008) \\
SN 2005cs, EPM, ver & $7,5(0,2)$ & Takáts \& Vinkó (2012) \\
SN 2005cs, EPM, vmodell & $8,6(0,2)$ & Takáts \& Vinkó (2012) \\
SN 2005cs + SN 2011dh, EPM & $8,4(0,7)$ & Vinkó és mtsai (2012a) \\
\hline fiatal csillagasszociációk (young stellar associations) & \\
${ }^{b}$ planetáris ködök luminozitásfüggvénye (planetary nebulae luminosity function) \\
${ }^{c}$ felületi fényesség fluktuáció (surface brightness fluctuation)
\end{tabular}

A más módszerekkel kapott eredményeket is figyelembe véve a Takáts \& Vinkó (2006) cikkben az M51 távolságát ezek átlagaként $D_{\mathrm{M} 51}=7,1 \pm 1,2 \mathrm{Mpc}$-nek állapítottam meg.

A Takáts \& Vinkó (2012) cikkben az SN 2005cs tágulási sebességét meghatároztam mind a SYNOW-val történő modellezés során, mind a vonalminimumok Doppler-eltolódásának mérésével (4.4.1. fej.). A kapott eredményeket - ahogy a többi SN esetében is - felhasználtam az EPM-mel történő távolságméréshez. Amikor a $v_{\mathrm{Fe}}$ sebességeket vettem figyelembe, a kapott távolság 7,5 $\pm 0,2 \mathrm{Mpc}$ lett, míg a $v_{\text {modell }}$ esetében $8,4 \pm 0,7 \mathrm{Mpc}$ volt az eredmény. A különböző módszerekkel meghatározott távolságok összehasonlításából (4.10. táblázat) kitúnik, hogy az utóbbi közelebb áll az SN 2005cs SEAM-mal kapott távolságaihoz. Az SN 2005cs és SN 2011dh adatainak kombinálásával kapott eredmény (ld 4.6. fej.) is a nagyobb távolságokat eredményező módszerekkel van összhangban.

\subsection{SN 2006bp}

Az SN 2006bp jelû́ szupernóvát az NGC 3953 galaxisban fedezte fel K. Itagaki 2006. április 9.60 UT-kor (Nakano \& Itagaki, 2006). Quimby és mtsai (2006) a Texas Supernova Search keretében készült képeket megvizsgálva azt találták, hogy április 9.15 UT-kor a szupernóva még nem volt látható (16.9 határmagnitúdóig), viszont az április 10.15 UT-kor készült képen már feltûnt. A szúrô nélkült készült képen a fényessége ekkor 15.3 magnitúdó volt. Tehát a felfedezés alig néhány órával a robbanás után történt. A Takáts \& Vinkó (2012) cikkben a robbanás időpontjaként a $t_{0}=2453835,0 \mathrm{JD}$ dátumot (április $9.50 \mathrm{UT}$ ) használtam.

A felfedezés után kb. 3 héten keresztuil jelentôs röntgen- és ultraibolya sugárzást is megfigyeltek. Immler és mtsai (2007) munkájuk során arra a következtetésre jutottak, hogy a röntgensugárzás oka a lökéshullám és a szupernóvát körülvevő CSM kölcsönhatása lehetett. Feltételezve, hogy a szülőcsillag tömegvesztési rátája $(\dot{M})$ és a csillagszél $v_{\mathrm{w}}$ sebessége 
állandó volt, Immler és mtsai $(2007) \dot{M} \approx\left(1 \times 10^{-5} \mathrm{M}_{\odot}\right.$ év $\left.^{-1}\right)\left(v_{\mathrm{w}} / \mathrm{kms}^{-1}\right)$ értéket határoztak meg.

Quimby és mtsai (2007) jó időfelbontású, ám szűrő nélkül készült fénygörbét és több, korai spektrumot is közöltek. Dessart és mtsai (2008) $U B V r^{\prime} i^{\prime}$ szürős fénygörbéket és néhány spektrumot is publikáltak. Ezeket, illetve Quimby és mtsai (2007) adatait felhasználva CMFGEN modelleket készítettek.

\subsubsection{Spektrummodellezés és sebességmérés}

A SYNOW modellezéshez a Quimby és mtsai (2007) által készített, a robbanás utáni 5. és 73. nap közötti időszakot lefedő spektrumokat használtam fel. Ők ennél korábbi spektrumokat is felvettek (ld. a 4. ábrájukat), de azok esetében még a hidrogén vonalai túlságosan gyengék, ezért ezek modellezése nem volt lehetséges. A felhasznált elsô 4, korai fázisban készített spektrum is csak a H I és He I vonalait tartalmazza (4.12. ábra). A 15. napon felvett spektrumban már megjelennek a Na I, Si II és az Fe II vonalai is, valamint az SN 2005cs-hez hasonlóan - itt is kimutatható az N II vonalainak jelenléte a $\mathrm{H} \alpha$, a $\mathrm{H} \beta$ és a He I 5876 Å mellett. A 20. naptól kezdve pedig már ezeken kívül a Ca II, Sc II, Ti II vonalai is azonosíthatóak, és a későbbi fázisokban egyre erősebbekké válnak. A létrehozott modellek paraméterei az A.5. táblázatban találhatók.

A $v_{\text {modell }}$ sebességet az első 4 spektrum esetében a $\mathrm{H} \beta$ vonalból állapítottam meg, a későbbiekben lehetett az Fe II 5169 Å-nél lévő vonalat használni. A kapott sebességek 12000 és $3800 \mathrm{kms}^{-1}$ közé esnek (4.11. táblázat, 4.13. ábra).

A vonalminimumok Doppler-eltolódásából meghatározott sebességek hasonlóan viszo-

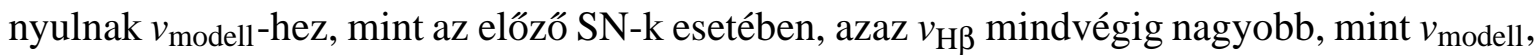
míg $v_{\mathrm{Fe}}$ az első 50 napban alacsonyabb nála, a különbség fokozatosan csökken, majd az 50. nap környékén $v_{\text {modell }}$ és $v_{\text {Fe }}$ körülbelül egyenlővé válik.

Ehhez a szupernóvához készültek CMFGEN modellek (Dessart és mtsai, 2008), ám az SN 1999em-mel és SN 2005cs-sel ellentétben az ekkor kapott $v_{\text {nlte }}$ sebességek és $v_{\text {modell }}$ értékei jelentősen különböznek. Mint ahogy az a 4.13. ábrán is látszik, korai idôpontokban ez a különbség még kevésbé jelentôs, $500-700 \mathrm{kms}^{-1}$. A robbanás utáni 15 . napon ez majdnem 0-ra csökken, majd újra nôni kezd. A 32. napon a legnagyobb a differencia, $1200 \mathrm{kms}^{-1}$. Ezután újra közelebb kerül egymáshoz a kétféle sebesség, de a különbség végig jelentős marad.

Amikor viszont a CMFGEN modelleket használtuk keresztkorrelációhoz (\#2-es készlet), a kapott sebességek a 9. napon készült spektrum kivételével jól egyezést mutattak $v_{\text {modell- }}{ }^{-}$ el. Az \#1-es készlet használatakor az eredmények a korai fázisban $v_{\mathrm{H} \beta}$-hoz, késóbb $v_{\mathrm{Fe}}-\mathrm{hoz}$ voltak hasonlók.

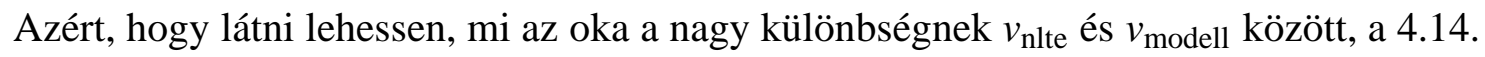
ábrán együtt ábrázoltam a robbanás utáni 32. napon észlelt spektrumot és a hozzá tartozó, a CMFGEN-nel valamint a SYNOW-val készült modellspektrumokat (ebben az idôpontban volt a legnagyobb a különbség a kétféle sebesség között). A jobb felsô sarokban lévő ábra a 4500-5500 Å közötti hullámhossztartományt emeli ki. Ezen jól látható, hogy az ebben a régióban található vonalakat a CMFGEN modell nem jól illeszti, az összes itt található vonal

sebességét alulbecsüli. Valószínúsíthetô tehát, hogy sebességek közötti különbség amiatt van, hogy a CMFGEN modellek illesztése ennek a szupernóvának az esetében valamilyen 
4.11. táblázat. Az SN 2006bp különböző módszerekkel kapott tágulási sebessége.

\begin{tabular}{cccccc}
\hline \hline $\begin{array}{c}\text { phase } \\
\text { (nap) }\end{array}$ & $\begin{array}{c}v_{\text {modell }} \\
\left(\mathrm{kms}^{-1}\right)\end{array}$ & $\begin{array}{c}v_{\mathrm{H} \beta} \\
\left(\mathrm{kms}^{-1}\right)\end{array}$ & $\begin{array}{c}v_{\mathrm{Fe}} \\
\left(\mathrm{kms}^{-1}\right)\end{array}$ & $\begin{array}{c}v_{\mathrm{cc \# 1} 1} \\
\left(\mathrm{kms}^{-1}\right)\end{array}$ & $\begin{array}{c}v_{\mathrm{ccH} 2} \\
\left(\mathrm{kms}^{-1}\right)\end{array}$ \\
\hline 5,80 & $12050(400)$ & $11251(350)$ & - & $11537(138)$ & $11131(571)$ \\
7,60 & $10750(450)$ & $11097(350)$ & - & $11407(103)$ & $10748(875)$ \\
9,60 & $9600(200)$ & $10526(300)$ & - & $10975(70)$ & $10242(657)$ \\
11,61 & $9550(450)$ & $10265(350)$ & - & $8717(69)$ & $9941(521)$ \\
15,60 & $8750(250)$ & $9735(250)$ & $8013(250)$ & $8373(67)$ & $9176(325)$ \\
20,78 & $8100(100)$ & $9104(250)$ & $7267(250)$ & $7506(79)$ & $8147(184)$ \\
24,76 & $7050(200)$ & $8278(250)$ & $6315(250)$ & $6573(45)$ & $7317(329)$ \\
32,76 & $6150(200)$ & $6996(250)$ & $5199(250)$ & $5548(28)$ & $6308(330)$ \\
43,71 & $5050(125)$ & $6078(250)$ & $4445(250)$ & $4698(46)$ & $5281(181)$ \\
56,69 & $4050(200)$ & $5562(250)$ & $3952(250)$ & $4022(40)$ & $4602(180)$ \\
72,54 & $3850(150)$ & $5313(250)$ & $3697(250)$ & - & - \\
\hline
\end{tabular}

4.12. táblázat. Az SN 2006bp és galaxisa, az NGC 3953 különböző módszerekkel kapott távolsága.

\begin{tabular}{lcl}
\hline Módszer & Távolság $(\mathrm{Mpc})$ & Referencia \\
\hline Tully-Fisher & $17,0(3,5)$ & Tully $(1988)$ \\
Tully-Fisher & $21,0(5,0)$ & Willick és mtsai $(1997)$ \\
Tully-Fisher & $15,7(1,3)$ & Springob és mtsai $(2009)$ \\
SN 2006bp, EPM, SEAM & $17,5(0,8)$ & Dessart és mtsai $(2008)$ \\
SN 2006bp, EPM, $v_{\mathrm{Fe}}$ & $18,6(1,5)$ & Takáts \& Vinkó $(2012)$ \\
SN 2006bp, EPM, $v_{\text {modell }}$ & $20,7(1,8)$ & Takáts \& Vinkó $(2012)$ \\
\hline
\end{tabular}

oknál fogva rosszabbul sikerültek, mint az SN 1999em és az SN 2005cs modellezése során.

\subsubsection{Távolság}

Az NGC 3953-nak, az SN 2006bp galaxisának a távolságát korábban már többször is meghatározták a Tully-Fisher-módszer segítségével, az eredmények 15,7 and 21,0 Mpc közé esnek (4.12. táblázat).

Dessart és mtsai (2008) az SN 2006bp távolságát - hasonlóan, mint az SN 2005cs esetében - kétféleképpen is kiszámították, egyrészt EPM-mel úgy, hogy a CMFGEN-nel történt modellezés során kapott sebességeket használták fel, másrészt a SEAM alkalmazásával. Végeredményként ók 17,5 $\pm 0,8$ Mpc-et kaptak.

Az EPM alkalmazása $v_{\text {modell }}$ felhasználásával ennél nagyobb távolságot, 20,7 $\pm 1,8$ Mpcet eredményezett. A különbség okai közt jelentős szerepet játszhat a $v_{\text {nlte }}$ és $v_{\text {modell }}$ közti, az előzőekben már ismertett, jelentős eltérés. A $v_{\mathrm{Fe}}$ sebességek használata kisebb távolságot, $18,6 \pm 1,5$ Mpc-et adott. 


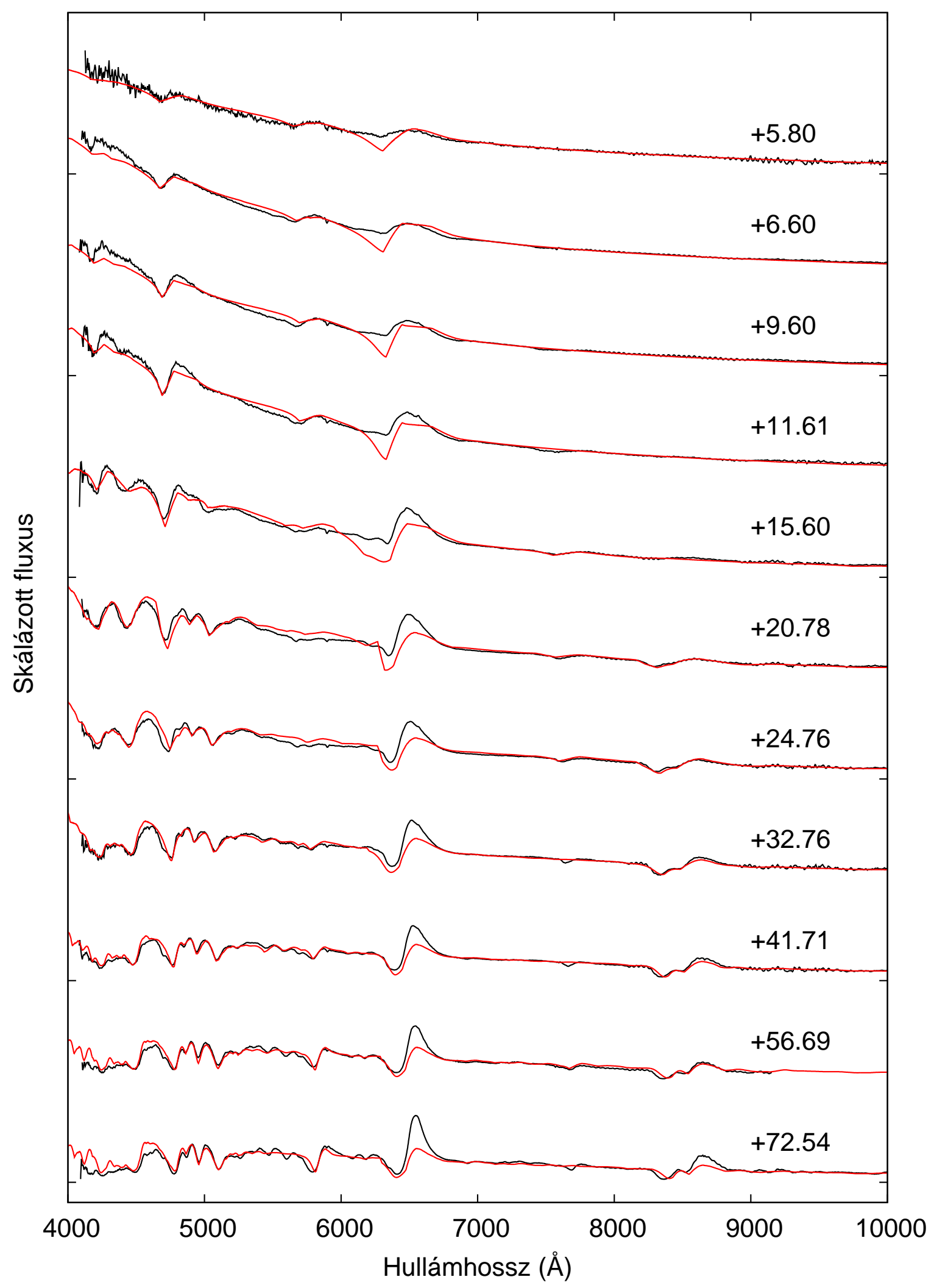

4.12. ábra. Az SN 2006bp spektrumai és a rájuk illesztett modellek. 


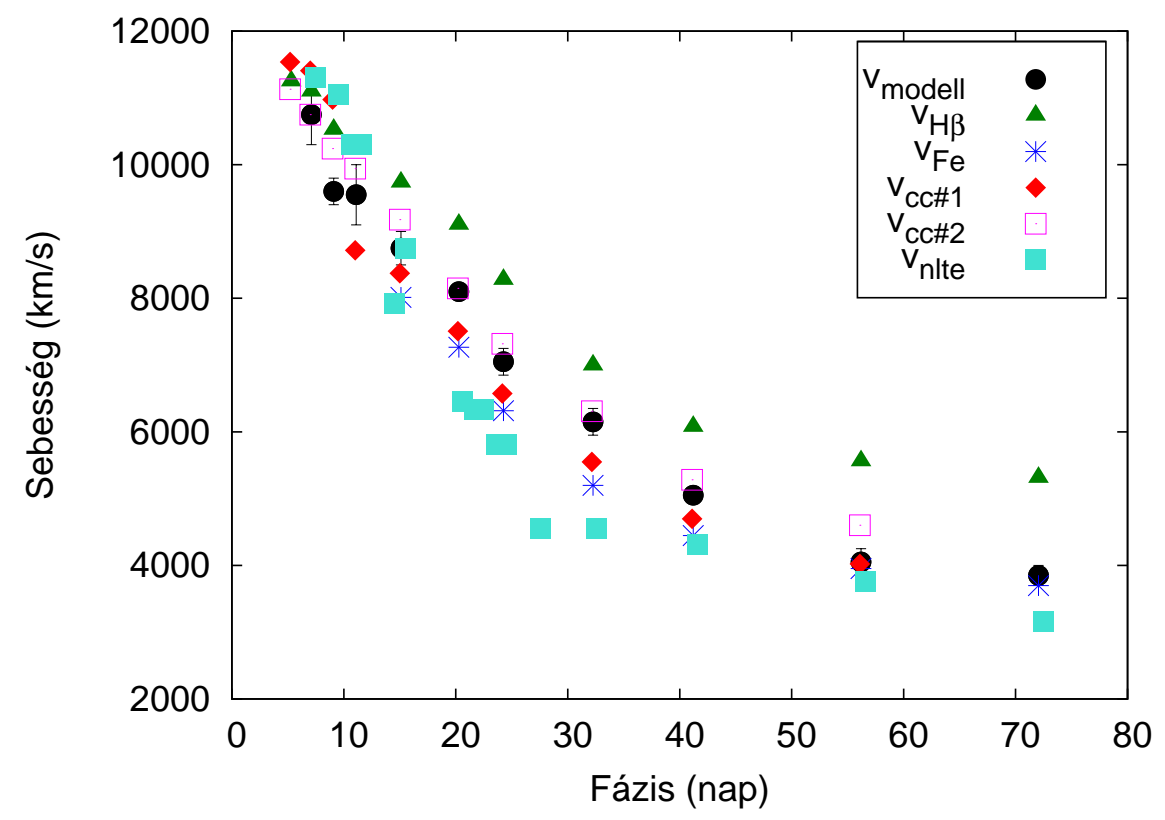

4.13. ábra. Az SN 2006bp sebességének különböző módszerekkel mért értékei.

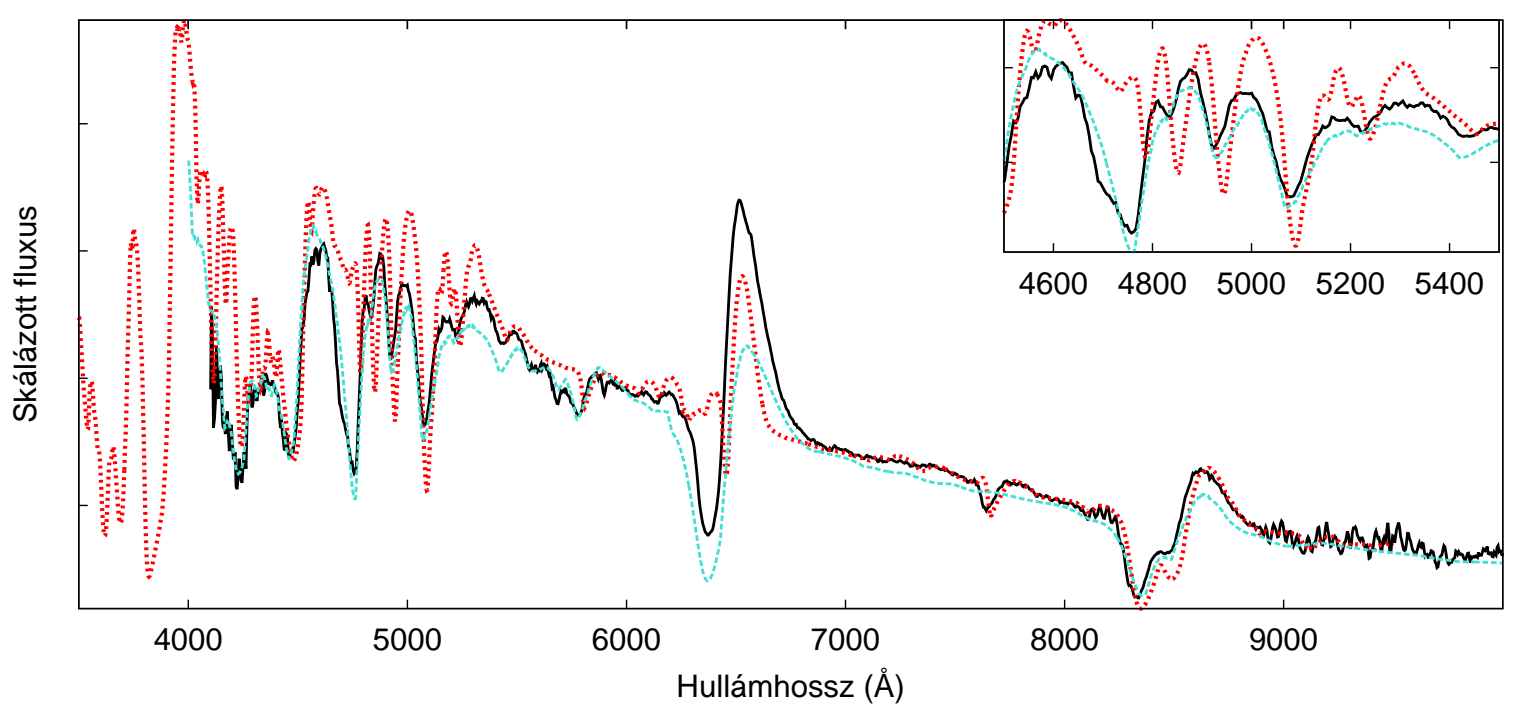

4.14. ábra. Az SN 2006bp észlelt spektruma (fekete) a robbanás utáni 32. napon, együtt a CMFGEN-el (piros) valamint a SYNOW-val (türkiz) készült modellspektrumokkal. A jobb felső sarokban a 4500 és 5500 Å közötti hullámhossztartomány látható kinagyítva. 


\section{6. $\mathrm{SN}$ 2011dh}

Az M51-ben megjelenő SN 2011dh jelú szupernóvát 2011. május 31,893 UT-kor fedezte fel A. Riou, és 2011. június 1,9 és 2,1 UT között több független megfigyelője is volt (Griga és mtsai, 2011). A Palomar Transient Factory május 31,275 UT-kor készített képet erről a területrôl, melyen az SN még $-m_{g}=21,44$ határmagnitúdóig - nem látszott (Arcavi és mtsai, 2011). Az észleléseknek köszönhetően a robbanás időpontja nagyon pontosan behatárolható, a továbbiakban a Arcavi és mtsai (2011) által meghatározott, $t_{0}=2455713,0 \pm 0,3$ JD (május 31,5 UT) értéket használom.

Ez a szupernóva több okból is rendkívül érdekes objektum. Egyrészt azért, mert a közeli M51-ben bukkant fel, melyben korábban már két másik SN-t is megfigyelhettünk, az Ic típusú SN 1994I-t és a II-P típusú SN 2005cs-t. Másrészt ez a szupernóva a IIb alcsoportba tartozik (1.4.3. fej.), és közelsége, valamint korai felfedezése végre nagyszerú lehetőséget biztosít ennek a ritka típusnak (1.1.1. fej.) a tanulmányozására.

Az M51-rôl jó minőségú archív felvételek állnak rendelkezésre a HST adatbázisában, amelyeket több csoport is megvizsgált a szupernóva szülő́csillaga után kutatva. Maund és mtsai (2011) az SN pozíciójában elhelyezkedő csillag fényességét és spektrális energiaeloszlását megvizsgálva azt egy $M_{\text {ZAMS }}=13 \pm 3 \mathrm{M}_{\odot}$ tömegú, F8 színképosztályú, kiterjedt $\left(R \sim 10^{13} \mathrm{~cm}\right)$ sárga szuperóriásként (yellow supergiant, YSG) azonosították. Nem zárták ki annak a lehetőségét sem, hogy a csillag egy kettős rendszer tagja legyen, de véleményük szerint ebben az esetben a társcsillag a detektálási küszöb alá esik, a teljes észlelt fluxus az elsődleges csillagtól származott. Van Dyk és mtsai (2011) ugyanennek a csillagnak a tömegét $M_{\text {ZAMS }}=17-19 \mathrm{M}_{\odot}$ nagyságúnak becsülték, viszont ők arra a következtetésre jutottak, hogy nem ez az objektum volt az SN szülőcsillaga. Szerintük a szupernóva megfigyelhetố tulajdonságai egy jóval kisebb méretú objektumra utalnak, tehát a szülőcsillag vagy nem látszik a megfigyelhető YSG csillag mellett, vagy esetleg annak egy kompakt, halványabb társcsillaga lehetett. Murphy és mtsai (2011) a környező csillagok vizsgálatával megbecsülték a csillagpopuláció korát és ezt használták fel a megfelelő izokron kiválasztásához. Így ốk a YSG tömegét $M_{\text {ZAMS }}=13_{-1}^{+2} \mathrm{M}_{\odot}$ értékúnek határozták meg, amely Maund és mtsai (2011) eredményével egyezik meg. Soderberg és mtsai (2012) a röntgen-, ultraibolya- valamint a rádiótartományban felvett adatok elemzése során arra a következtetésre jutottak, hogy a szülőobjektum egy kompakt csillag volt, sugara $R \approx 10^{11} \mathrm{~cm}$ nagyságrendú lehetett. Bersten és mtsai (2012) viszont az SN fénygörbéjének hidrodinamikai modellezése során azt találták, hogy a szülő́csillag egy $M_{\text {ZAMS }}=12-15 \mathrm{M}_{\odot}$ tömegú, kiterjedt csillag lehetett, amely körül csak egy nagyon vékony $\left(\sim 0,1 \mathrm{M}_{\odot}\right)$ hidrogénburok volt. Tehát szerintük valóban az archív felvételeken detektált YSG volt a szülő́csillag. Mivel a jelenlegi csillagfejlődési modellek szerint elég valószínútlen, hogy egy egyedi csillag ilyen YSG csillaggá fejlődjön, Benvenuto és mtsai (2012) olyan kettős rendszert modelleztek, ahol a fókomponens $\left(M_{\mathrm{ZAMS}}=16 \mathrm{M}_{\odot}\right)$ a Bersten és mtsai (2012) által leírt YSG csillaggá fejlődött, míg kisebb tömegú $\left(M_{Z A M S}=10 \mathrm{M}_{\odot}\right)$ társa a szupernóva-robbanás bekövetkeztekor még a fôsorozat közelében helyezkedett el. A szülőcsillag utáni kutatás majd a szupernóva elhalványodása után, a terület újabb vizsgálatával folytatódhat.

A szupernóvát azóta is több csoport követi folyamatosan, ám egyelőre még a legtöbben nem közöltek hosszabb adatsorokat, az eredmények publikálása csak később várható. Bersten és mtsai (2012) a fénygörbének az első 80 napot lefedő szakaszát használták a modelljük 
elkészítéséhez. Ez alapján a robbanás energiáját $E_{\text {exp }}=6-10 \times 10^{50}$ ergnek, míg a keletkezett ${ }^{56} \mathrm{Ni}$ tömegét $\sim 0,06 \mathrm{M}_{\odot}$ nagyságúnak becsülték. Tsvetkov és mtsai (2012) a robbanást követő nagyjából 300 napban készített fotometriai észleléseket publikálták. A fénygörbék modellezésével a $\mathrm{SN}$ több fizikai paraméterét is meghatározták. A robbanás energiájára modelltől függóen $-E_{\text {exp }}=1,5-4 \times 10^{51}$ erg-et, a ledobódott burok tömegére $M_{e j}=2,4 \mathrm{M}_{\odot}$ értéket, míg a csillag sugarára a robbanás bekövetkezte előtt $R_{i n i}=300-562 \mathrm{R}_{\odot}$ értéket, a keletkezett ${ }^{56} \mathrm{Ni}$ tömegére pedig $M_{N i}=0,07 \mathrm{M}_{\odot}$ nagyságot kaptak.

Az SN 2011dh jelentős röntgensugárzást mutatott. Soderberg és mtsai (2012) kb. egy hónapon keresztül készítettek méréseket röntgen-, ultraibolya- és rádiótartományban. Szupernóvák esetében a röntgensugárzás forrásaként háromféle folyamat jöhet szóba: a $10^{6} \mathrm{~K}$ nél forróbb plazma hőmérsékleti sugárzása, az inverz Compton-szórás és a szinkrotron sugárzás. Mind Soderberg és mtsai (2012), mind Maeda (2012) arra a következtetésre jutott, hogy az SN 2011dh esetében (mint ahogyan általában az Ib/c és IIb SN-k esetében) a megfigyelt rádió- és röntgensugárzás forrása az inverz Compton-szórás volt (tehát az eredetileg kisebb energiájú fotonok a nagy sebességû elektronokon történő szóródásuk során energiára tettek szert).

\subsubsection{Spektrummodellezés és sebességmérés}

A felhasznált, Vinkó és mtsai (2012a) cikkében közölt spektrumok a Hobby-Eberly Telescope (HET) Marcario Low Resolution Spectrograph (LRS) múszerével készültek 2011. június 6. és 29. között (Marion és mtsai, előkészületben). Ezek a robbanást követô 5. és 29. nap közötti időszakot fedik le.

A SYNOW modellezés során a H I, He I, Ca II, Ti II és Fe II vonalait, illetve néhány esetben az O I és az Sc II jelenlétét mutattam ki (A.6. táblázat). Az észlelt spektrumok a modellekkel együtt a 4.15. ábrán láthatóak. A Ilb típusú szupernóvákra jellemzó módon a H I vonalai jóval gyengébbek, a He I vonalai pedig erôsebbek, mint a II-P típusúak esetében.

A $v_{\text {modell }}$ értékének meghatározása minden időpontban az Fe II 5169 Å vonalának segítségével történt. A kapott sebességek 11400 és $5600 \mathrm{kms}^{-1}$ közé esnek (4.13. táblázat, 4.16. ábra). Mivel ennek a szupernóvának egészen más jellegúek a spektrumai, mint a IIP típusúaké, ezért keresztkorrelációt ebben az esetben nem végeztem. A vonalminimumok Doppler-eltolódásából mért sebességek közül a $v_{\mathrm{Fe}}$ értékei nagyon hasonlóak $v_{\text {modell-hez, }}$ általában azoknál valamivel alacsonyabbak. A $v_{\mathrm{H} \beta}$ viszont minden idôpontban jelentôsen nagyobb, mint $v_{\text {modell }}$, az utolsó időpontban kétszerese annak. Az a tény, hogy a $\mathrm{H} \beta$ meglehetősen gyenge, viszont a környékén sok erős fémvonal található, felveti annak a lehetôségét, hogy a vonalat rosszul azonosítottam, vagy pedig a többi vonal miatt nem is azonosítható a minimuma, és emiatt ilyen kaptam ilyen nagy sebességkülönbséget. Ezért megmértem a tágulási sebességet a $\mathrm{H} \alpha$ minimumából is, és ezeket - a többi sebességgel együtt - feltüntettem a 4.16. ábrán. Itt látható, hogy ezek a sebességek is jelentôsen nagyobbak, mint akár $v_{\text {modell }}$, akár $v_{\mathrm{Fe}}$ értékei.

\subsubsection{Távolság}

Az M51 távolságának meghatározására tett próbálkozásokról az SN 2005cs kapcsán már volt szó a 4.4. fejezetben. A különböző módszerekkel kapott eredmények összefoglalva a 
4.13. táblázat. Az SN 2011dh különböző módszerekkel kapott tágulási sebessége.

\begin{tabular}{cccc}
\hline \hline $\begin{array}{c}\text { Fázis } \\
(\text { nap})\end{array}$ & $\begin{array}{c}v_{\text {modell }} \\
\left(\mathrm{kms}^{-1}\right)\end{array}$ & $\begin{array}{c}v_{\mathrm{H} \beta} \\
\left(\mathrm{kms}^{-1}\right)\end{array}$ & $\begin{array}{c}v_{\mathrm{Fe}} \\
\left(\mathrm{kms}^{-1}\right)\end{array}$ \\
\hline 5,3 & $11400(200)$ & $12939(500)$ & $10192(350)$ \\
10,3 & $9250(300)$ & $11034(500)$ & $8553(300)$ \\
13,3 & $7250(250)$ & $10684(500)$ & $7229(300)$ \\
16,3 & $7200(300)$ & $10687(500)$ & $7021(300)$ \\
20,3 & $7250(200)$ & $10723(500)$ & $6533(250)$ \\
21,3 & $7150(150)$ & $10910(500)$ & $6435(250)$ \\
28,7 & $5600(200)$ & $10855(500)$ & $5287(250)$ \\
\hline
\end{tabular}

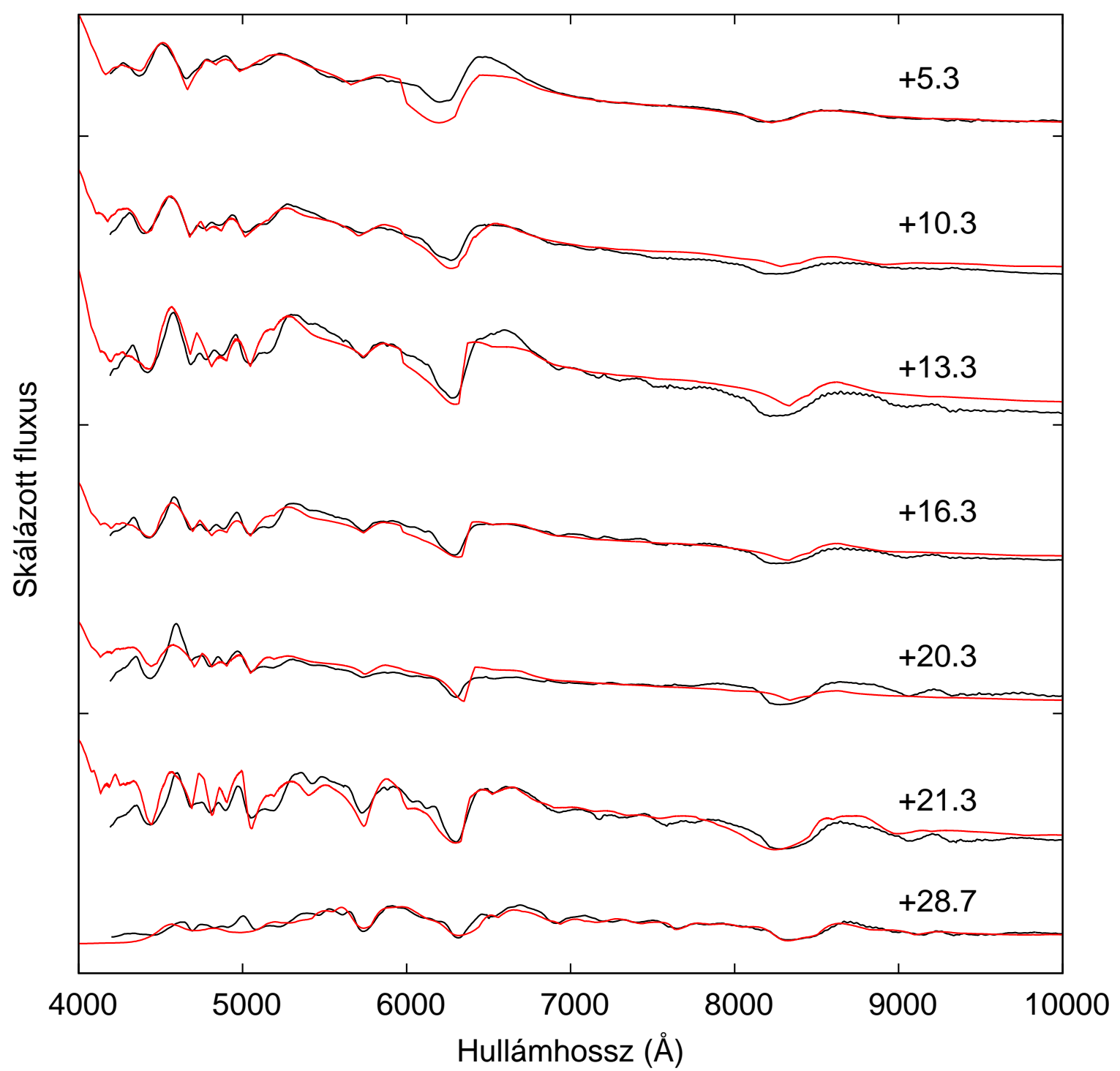

4.15. ábra. Az SN 2011dh spektrumai és a rájuk illesztett modellek. 


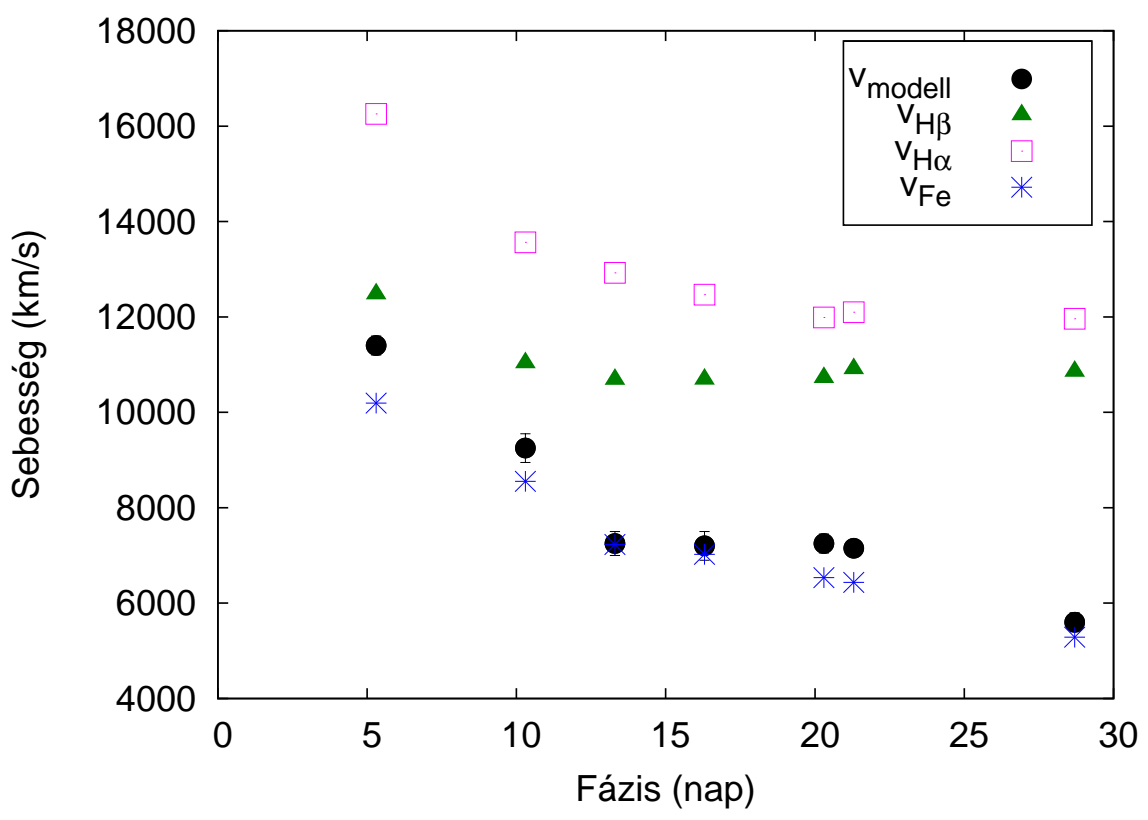

4.16. ábra. Az SN 2011dh különböző módszerekkel meghatározott tágulási sebessége.

4.10. táblázatban láthatóak.

A Vinkó és mtsai (2012a) cikkben a távolságmeghatározáshoz a SYNOW-val végzett modellezés során kapott sebességeket használtuk. Kombináltuk az SN 2005cs és az SN 2011dh adatait és kihasználtuk, hogy mindkét szupernóva esetében pontosan ismert a robbanás időpontja. Az EPM alkalmazása során nehézséget jelentett, hogy a II-P típusú szupernóvák modellezésével kapott korrekciós faktorok (2.2.3. fej.) nem alkalmazhatóak IIb típusú SNkre. Ezért az SN 2011dh esetében minden időpontban $\zeta=1$ értéket használtuk. A korrekciós faktor figyelembevétele a korai fázisban ugyanis nagyrészt a hidrogén ionizációja miatt jelen lévő szabad elektronokon való szóródás miatt szükséges (2.2.3. fej.). Viszont IIb típusú szupernóvák esetében ez a réteg nagyon vékony, tehát a termalizációs mélység és a fotoszféra jóval közelebb helyezkedik el egymáshoz, mint a II-P típusú SN-k esetében.

Az EPM alkalmazása során az egyenesillesztést (2.4 egyenlet) a két szupernóva kombinált adataira végeztük. Mindkét SN esetében a robbanást követő 5. és 25. nap közti adatokat vettük figyelembe. Az alsó határ választásának oka az volt, hogy a robbanás után el kell telnie néhány napnak, hogy a tágulás valóban homológ legyen. A felsô határ megválasztását pedig az indokolta, hogy az EPM alkalmazásakor használt alapfeltevések csak a robbanást követő 30-50 napban érvényesek (2.2. fej.). Ebben az esetben pedig két olyan SN-ról van szó, amelyek hidrogénburka vékony, tehát a többi, ,átlagos” II-P SN-hez képest az atmoszférájuk gyorsabban válik átlátszóvá, rövidebb az az időtartam, amikor az EPM alkalmazható.

A két szupernóva adatainak együttes fehasználásával az M51 távolságára $D=8,4 \pm$ 0,7 Mpc-et kaptunk. Ez hasonló ahhoz, amit Baron és mtsai (2007), illetve Dessart \& Hillier (2006) kapott a SEAM-mal, illetve ahhoz, amit a $v_{\text {modell }}$ sebességek felhasználásával határoztam meg az SN 2005cs távolságára (4.10. táblázat; Takáts \& Vinkó, 2012). 


\section{5. fejezet}

\section{Következtetések}

Az előző fejezetben külön-külön ismertettem az egyes szupernóvák esetében kapott eredményeket. Ebben a részben ezek összehasonlítására, együttes tárgyalására kerül sor, valamint a II-P SN-kre vonatkozóan általános következtetéseket is levonom.

A spektrumok tanulmányozásából és modellezéséből kitúnik, hogy a vizsgált II-P SNk mindegyike nagyrészt ugyanazokat az atomokat és ionokat tartalmazza, és a spektrumok időbeli változása is igen hasonló. A 5 db II-P típusú SN (1999em, 2004dj, 2004et, 2005cs, 2006bp) közül feltûnően csak a többinél kisebb fényességú SN 2005cs mutatott jelentôsen eltérô tulajdonságokat. Ennek a spektruma gyorsabban változott, mint a többié, a vonalak keskenyebbek, kisebb tágulási sebességre utaltak, valamint megfigyelhetô volt a tipikusan az alacsonyabb luminozitású II-P SN-kre jellemző erôs Ba II vonalak korai megjelenése is. Ez a szupernóva más fizikai tulajdonságaiban is eltért a többi, "normális" II-P-től: a robbanás kisebb energiájú volt és az SN szülőcsillaga is valamivel kisebb tömeggel rendelkezett (4.4. fej.).

Az előző fejezetben ismertettem az 5 II-P típusú SN mért tágulási sebességét a plató fázisban. A különböző módszerek alkalmazásával az alábbi sebességeket kaptam:

i) a SYNOW nevú programmal létrehozott, az észlelt spektrumokra illesztett modellek segítségével kapott sebességek: $v_{\text {modell }}$;

ii) a H $\beta$ és az Fe II 5169 Å vonalak abszorpciós minimuma Doppler-eltolódásából: $v_{\mathrm{H} \beta}$ és $v_{\mathrm{Fe}}$, illetve összefoglaló jelöléssel $v_{\mathrm{abs}}$;

iii) az SN 1999em, 2005cs és 2006bp esetében rendelkezére álltak NLTE kóddal létrehozott modellspektrumok, melyek fotoszferikus sebessége ismert, $v_{\text {nlte }}$;

iv) a keresztkorreláció során két készletet használtam; az \#1 készlet az SN 1999em észlelt spektrumait tartalmazta, míg a \#2 készlet az SN 1999em, 2005cs és 2006bp NLTE modellspektrumaiból állt; az így kapott sebességeket $v_{\mathrm{cc \# 1}}$ és $v_{\mathrm{cc \# 2}}$ módon jelölöm.

Az 5.1 és az 5.2. ábrákon a különböző módszerekkel kapott eredmények összevetése látható a robbanás óta eltelt napok számának a függvényében. Az 5.1. ábra bal felsô képén a $v_{\text {modell }}$ sebességek időbeli lefutását hasonlítom össze. Itt megfigyelhetô, hogy az SN 1999em, 2004et és 2006bp sebességgörbéje meglehetősen hasonló, a görbe meredeksége mutat csupán kismértékû eltéréseket. Az SN 2004dj sebességgörbéje nagy valószínúséggel 
ugyanilyen lehetett, bár a viszonylag késői felfedezés miatt ezt nem tudtam megvizsgálni. Ezzekel szemben az SN 2005cs sebességgörbéje jelentősen különbözik. Ez a szupernóva már korai fázisban jóval kisebb sebességgel rendelkezett, mint a másik négy, és a sebesség csökkenése is gyorsabb volt.

Az 5.1. ábra jobb felsố képén az NLTE modellezésből származó $v_{\text {nlte }}$ sebességeket hasonlítom össze $v_{\text {modell }}$ értékeivel. Kitúnik, hogy míg az SN 1999em és 2005cs esetében a kétféle sebesség 10-15\%-on belül megegyezik (egy kilógó pont kivételével az SN 2005cs esetében), addig az SN 2006bp $v_{\text {modell }} / v_{\text {nlte }}$ aránya sokkal nagyobb szórást mutat. Ezt az eltérést már a 4.5. fejezetben is megvizsgáltam, és a 4.14. ábra segítségével megmutattam, hogy ennek a szupernóvának az esetében az NLTE modell illesztése kevésbé jól sikerült, mint más szupernóvák esetében. Ugyanakkor $v_{\text {modell }}$ és $v_{\text {nlte között szisztematikus eltérés }}$ nem figyelhetô meg. Ez arra utal, hogy a spektrummodellek - akár SYNOW, akár CMFGEN - segítségével konzisztens eredményeket kapunk, míg az abszopciós minimumból vagy pedig keresztkorrelációval kapott sebességek fázisfüggő eltérést mutatnak $v_{\text {modell-től. Emiatt }}$ a gyakran használt sebességmérési eljárások a valódi fotoszferikus sebességet a robbanást követô elsô kb. 50 napban alul-, míg későbbi fázisban túlbecsülik, méghozzá egyre növekvő és az egyes szupernóvák esetében eltérô mértékben. Ez jelentôs hibát eredményezhet olyankor, mikor a valódi fotoszferikus sebesség szükséges, például az EPM vagy az SCM alkalmazásakor.

Az 5.1. ábra két alsó képén a vonalminimumok Doppler-eltolódásából mért sebességek és $v_{\text {modell }}$ összehasonlítása látható az idő függvényében. Elsô pillantásra is észrevehetô, hogy mindkét diagramon jelentős különbségek vannak az egyes szupernóvák esetében, bár az általános tendencia igen hasonló. A $v_{\mathrm{Fe}} / v_{\text {modell }}$ arány a korai fázisban valamivel 1 alatt van, majd a robbanás utáni 40-50. nap környékén éri el 1-et. Ezt követően az arány folyamatosan nő a plató fázis végéig, bár a növekedés mértéke szupernóvánként meglehetősen különböző. A $v_{\mathrm{H} \beta}$ és $v_{\text {modell }}$ a korai fázisban körülbelül egyenlő, majd $v_{\mathrm{H} \beta}$ fokozatosan egyre nagyobbá válik a másiknál. A két sebesség arányának változása szintén objektumonként különböző, az SN 1999em esetében például még a robbanás utáni 80. napon is csak kicsit haladja meg az egyet $v_{H_{\beta}} / v_{\text {modell }}$ értéke, míg az SN 2004et esetében a plató fázis végére ez $\sim 2,5$-re nő.

Az 5.2. ábrán a keresztkorrelációval kapott sebességeket hasonlítom össze $v_{\text {modell }}$ és $v_{\text {abs }}$ értékeivel. Itt $v_{\mathrm{abs}}$ a korai fázisban $v_{\mathrm{H} \beta}$-t jelenti, majd a vasvonalak megjelenése után már $v_{\mathrm{Fe}}$-vel egyenlô. Az ábrákon megfigyelhetô, hogy a keresztkorrelációval kapott sebességek általában jobb egyezést mutatnak a $v_{\text {abs }}$, mint a $v_{\text {modell }}$ értékeivel. Ez érthetô is, hiszen a keresztkorrelációs módszer a spektrumvonalak alakjára és pozíciójára érzékeny. Az is észrevehetô, hogy a $v_{\text {modell }} / v_{\mathrm{cc}}$ arány (5.2. ábra bal felsô kép) és a $v_{\mathrm{Fe}} / v_{\text {modell }}$ arány (5.1. ábra bal alsó kép) időbeli változása hasonló menetú: a robbanás utáni 10. és 50. nap között $v_{\text {modell }}$ a nagyobb, viszont az 50. nap után $v_{\mathrm{cc}}$ illetve $v_{\mathrm{Fe}}$ értéke válik magasabbá. Ez és a $v_{\mathrm{abs}} / v_{\mathrm{cc} \# 1}$ arány (5.2. ábra jobb felsô kép) is azt mutatja, hogy az \#1 (az SN 1999em észlelt spektrumait tartalmazó) készlettel történő keresztkorreláció a $v_{\mathrm{Fe}}$ sebességet $\sim 10 \%$-os pontossággal képes megbecsülni. Ez alátámasztja Poznanski és mtsai (2009) azon módszerét, hogy rossz jel/zaj viszonyú spektrumok $v_{\mathrm{Fe}}$ sebességét ezzel a módszerrel becsülik meg (ld. még 2.2.2 fej.)

A különböző módszerekkel kapott sebességek közötti összefüggések további vizsgálatához az 5.3. ábrán ábrázoltam a $v_{\mathrm{Fe}} / v_{\text {modell }}$ és a $v_{\mathrm{H} \beta} / v_{\text {modell }}$ arányt a $v_{\text {modell }}$ függvényében. A $v_{\mathrm{Fe}} / v_{\text {modell }}$ arány változása mindegyik SN esetében hasonló: nagy sebességeknél 

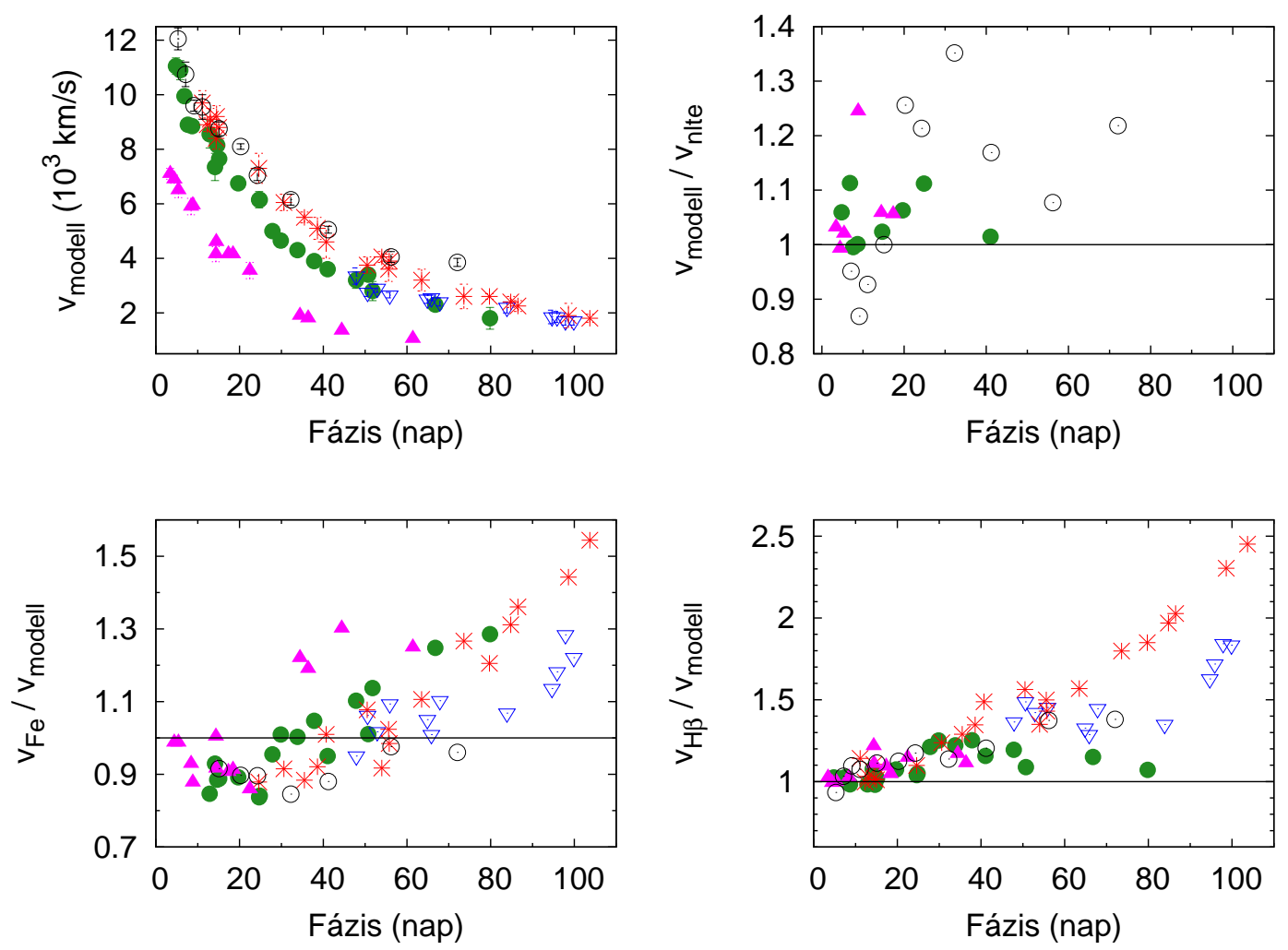

5.1. ábra. A SYNOW modellezés során kapott $v_{\text {modell }}$ sebességek összehasonlítása a különböző szupernóvák esetében (balra fent). A $v_{\text {modell }} / v_{\text {nlte }}$ arány (jobbra fent), a $v_{\mathrm{Fe}} / v_{\text {modell }}$ (balra lent) és a $v_{\mathrm{H} \beta} / v_{\text {modell }}$ (jobbra lent) arány a fázis függvényében. Az egyes szupernóvákat más-más szimbólumok jelölik: zöld, teli pötty - SN 1999em; kék, üres háromszög - SN 2004dj; piros, csillag - SN 2004et; rózsaszín, teli háromszög - SN 2005cs; fekete, üres kör - SN 2006bp.

(azaz korai fázisban) az arány valamivel alacsonyabb egynél és lassan növekszik. Körülbelül $v_{\text {modell }}=4000 \mathrm{kms}^{-1}$-nél éri el az egyet, és ahogy a sebesség tovább csökken, úgy nô az arány, mely a plató fázis végére az $\sim 1,6$ lesz.

A $v_{\mathrm{H} \beta} / v_{\text {modell }}$ lefutása kevésbé egységes. Nagy $v_{\text {modell }}$ értékeknél (korai fázisban) az arány 1 körül alakul, és $v_{\text {modell }}=7000 \mathrm{kms}^{-1}$ környékén haladja meg azt. Ezután viszont változása szupernóvánként különböző. Az SN 1999em és 2005cs esetében végig viszonylag alacsony marad, a plató fázis végére sem haladja meg 1,4-et, míg a másik három objektum esetében jóval magasabbá válik. SN 2006bp esetében sajnos nem volt olyan spektrum, amelyre $v_{\text {modell }}<3850 \mathrm{kms}^{-1}$, bár addig a sebesség változása meglehetősen hasonló az SN 2004et-éhez.

Az 5.3. ábra hasonló ahhoz, amit Dessart \& Hillier (2005b) készítettek a CMFGEN modellspektrumaik alapján (ld. 14. ábrájukat). Ők megmérték a létrehozott modellspektrumok vonalai abszorpciós minimumának Doppler-eltolódásából a sebességeket, és ábrázolták ezeknek és a modellek fotoszferikus sebességének $\left(v_{\text {nlte }}\right)$ arányát az utóbbi függvényében. 

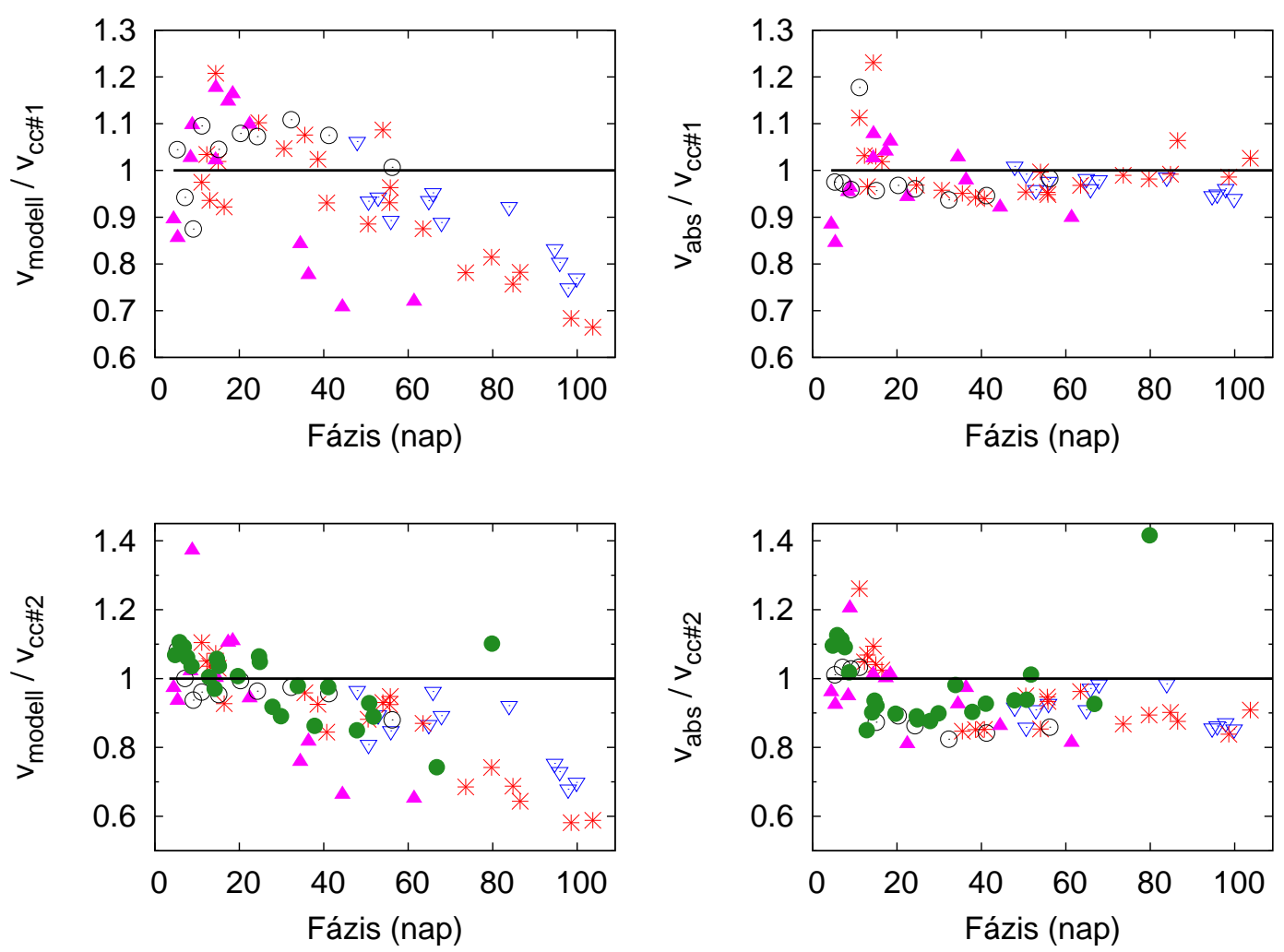

5.2. ábra. A $v_{\text {modell }}$ és $v_{\mathrm{abs}}$ valamint a $v_{\mathrm{cc}}$ sebességek aránya a robbanás utáni eltelt idő függvényében. A különböző szimbólumok a különböző szupernóvákat jelölik az 5.1. ábrán feltüntetett módon.
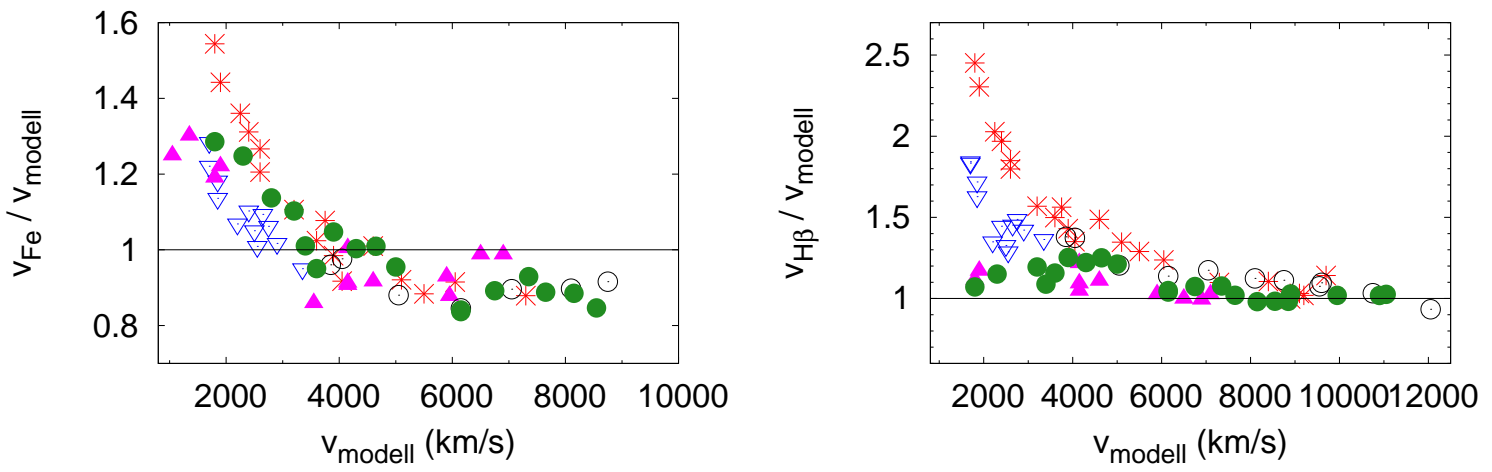

5.3. ábra. A $v_{\mathrm{Fe}} / v_{\text {modell }}$ (balra) és a $v_{\mathrm{H} \beta} / v_{\text {modell }}$ (jobbra) arány a $v_{\text {modell }}$ sebesség függvényében. Az egyes szimbólumok a különböző szupernóvákat jelentik, az 5.1. ábránál leírt módon. 
Habár ôk nem rendelkeztek adatokkal kb. $4000 \mathrm{kms}^{-1}$ alatti sebességekről, és az én, öt SNt tartalmazó mintámban pedig a felső határ $\left(12050 \mathrm{kms}^{-1}\right)$ kisebb, mint náluk, e között a két érték között az eredményeik egészen hasonlóak az általam kapottakhoz. Az ő ábrájukon az Fe II $5169 \AA$ vonalra számolt sebességek korai fázisban alacsonyabbak, mint $v_{\text {nlte, az }}$ arányuk 1-et valahol 5000 és $4000 \mathrm{kms}^{-1}$ között éri el, hasonlóan az én méréseim eredményéhez. Viszont $\mathrm{H} \beta$ esetében vannak különbségek. Korai fázisban a két munka eredményei konzisztensek, $11000 \mathrm{kms}^{-1}$ felett a $v_{\mathrm{H} \beta} / v_{\text {modell }}$ arány mindkét esetben 1 körül van. Dessart \& Hillier (2005b) ábráján ez az arány 1-et $8000 \mathrm{kms}^{-1}$ környékén haladja meg, és a legmagasabb értéke csak 1.15 körül van. Ez jóval alacsonyabb, mint az általam kapott, ahogy az az 5.3. ábrán is látható. Azonban Dessart \& Hillier (2005b) az SN 1987A és az SN 1999em észlelt spektrumai alapján készítették a modelljeiket. Az utóbbi SN az általam vizsgált 5 szupernóva egyike, és az esetében kapott $v_{\mathrm{H} \beta} / v_{\text {modell }}$ arány hasonló ahhoz, ami Dessart \& Hillier (2005b) ábráján szerepel. Így tehát a különbség oka valószínúleg az, hogy a CMFGEN modellek nem elég nagy paramétertartomány lefedésével készültek, hiányoznak például az SN 2004et-éhez hasonló spektrumok.

\subsection{Sebesség-sebesség relációk}

A gyakorlatban gyakran nem áll rendelkezésünkre egy szupernóváról olyan kiváló minőségú, jó idôbeli felbontású spektrum-sorozat, amelynek felhasználásával alkalmas sebességgörbét állíthatunk elő. Ezért fontos a kvantitatív vizsgálata annak, hogy az egyes módszerek hogyan függnek össze egymással, hogyan lehet segítségükkel a fotoszferikus sebességre következtetni, illetve más időpontokra extrapolálni. Mivel munkám során több szupernóva jó minőségű spektrumából több módszerrel is megmértem a sebességet, ezért alkalmas adatok álltak rendelkezésemre ahhoz, hogy ilyen jellegú vizsgálatokat végezzek.

Hasonló összefüggések felállításával korábban már mások is foglalkoztak. Az Eastman és mtsai (1996) és Dessart \& Hillier (2005a) által készített NLTE modellspektrumok felhasználásával Jones és mtsai (2009) megvizsgálták a $v_{\mathrm{H} \beta}$ and $v_{\text {nlte }}$ közti kapcsolatot. Azt találták, hogy arányuk leírható a következő összefüggéssel:

$$
\frac{v_{\mathrm{H} \beta}}{v_{\mathrm{nlte}}}=\sum_{j=0}^{2} a_{j} v_{\mathrm{H} \beta}^{j}
$$

A két különböző modellkészletre általuk kapott $a_{j}$ értékek az 5.1. táblázatban találhatóak. Ezeket a görbéket összehasonlítottam az általam kapott sebességekkel. Az 5.4. ábrán megfigyelhetô, hogy a Dessart \& Hillier (2005a) modelljein alapuló görbe túlbecsüli a $v_{\text {modell }}$ sebességeket (rms $\sigma=0,412$ ), míg a Eastman és mtsai (1996) modelljein alapuló eléggé jól illeszti azokat, kivéve az SN 2004et adatait ( $\mathrm{rms} \sigma=0,301$, de $\sigma=0,178$ az SN 2004et adatai nélkül).

Az 5.1. összefüggés illesztését én is elvégeztem az általam mért sebességekre (5.4. ábra fenti képe, fekete folytonos görbe). A kapott $a_{j}$ értékek az 5.1. táblázatban találhatóak. A szórás az eredeti görbével kapottnál alacsonyabb, $\sigma=0,276$ lett. Az illesztést megismételtem úgy is, hogy kihagytam az SN 2004et sebességeit, ekkor az eredmény egészen hasonló lett ahhoz, amelyet Jones és mtsai (2009) Eastman és mtsai (1996) modelljeivel kaptak. 

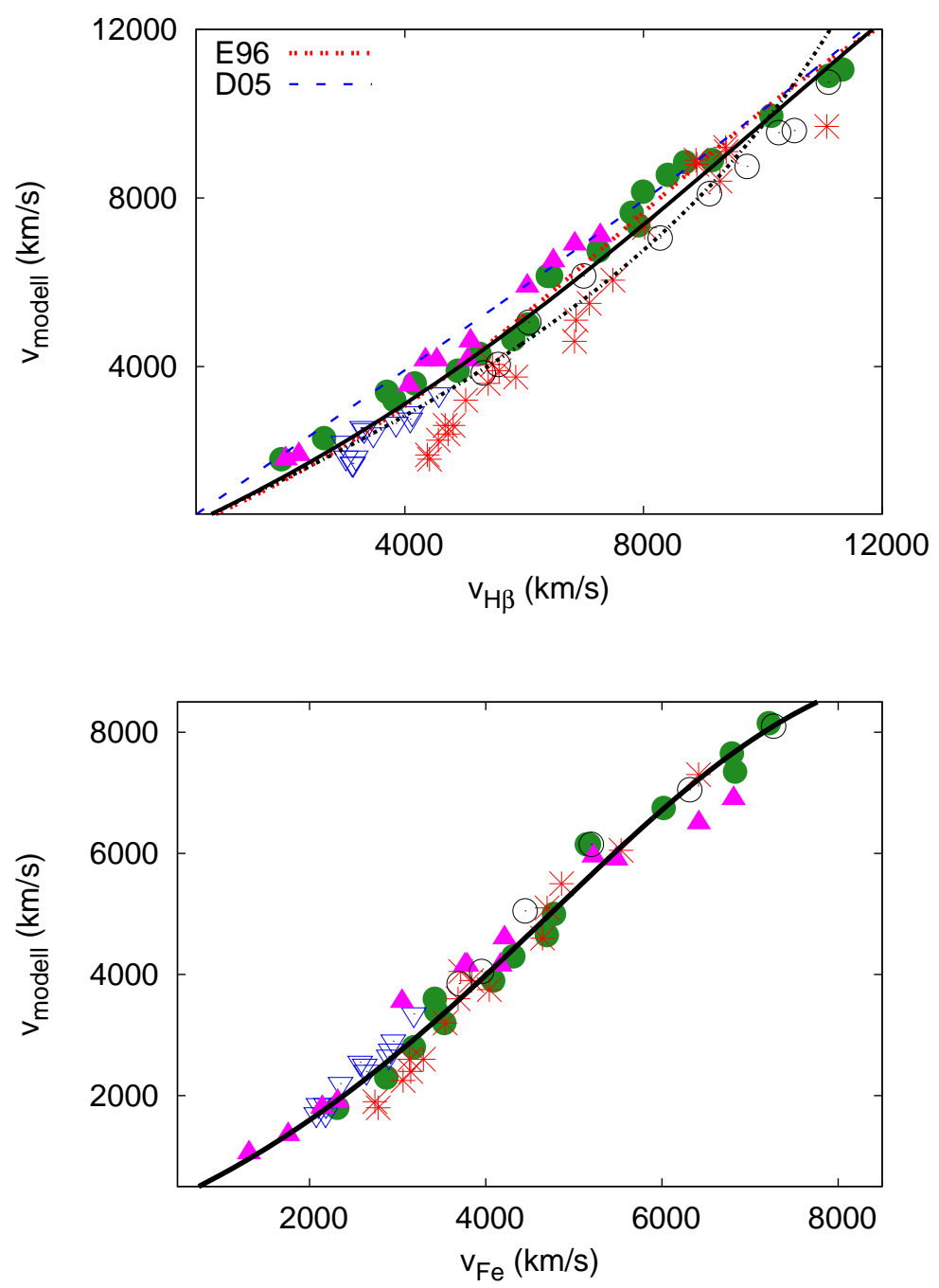

5.4. ábra. Fent: $v_{\text {modell }}$ sebesség $v_{\mathrm{H} \beta}$ függvényében. A görbék mutatják a Jones és mtsai (2009) által egyrészt Eastman és mtsai (piros pontozott vonal), másrészt Dessart \& Hillier (kék szaggatott vonal) modelljei alapján meghatározott polinomokat. Feltüntettem azokat a görbéket is, melyeket a Takáts \& Vinkó (2012) cikkben meghatározott sebességekre történt illesztéssel kaptam, egyrészt mind az öt SN felhasználásával (fekete pontozott vonal), másrészt a SN 2004et kihagyásával (fekete folytonos vonal). Lent: az illesztés a $v_{\mathrm{Fe}}$ sebességek esetében is elvégeztem, mind az öt SN adataira. Mindkét ábra esetében a szimbólumok a különböző szupernóvákat jelentik, az 5.1. ábrán leírt módon. Az illesztett polinomok koefficiensei az 5.1. táblázatban találhatóak. 
5.1. táblázat. Az (5.1) egyenlet illesztése során kapott $a_{j}$ koefficiensek mind $v_{\mathrm{H} \beta}$, mind $v_{\mathrm{Fe}}$ esetében.

\begin{tabular}{lccccl}
\hline $\mathrm{j}$ & 0 & 1 & 2 & $\sigma$ & Forrás \\
\hline$a_{j}\left(H_{\beta}\right)(\mathrm{E} 96)$ & 1,775 & $-1,435 e-4$ & $6,523 e-9$ & 0,30 & Jones és mtsai (2009) \\
$a_{j}\left(H_{\beta}\right)(\mathrm{D} 05)$ & 1,014 & $4,764 e-6$ & $-7,015 e-10$ & 0,41 & Jones és mtsai (2009) \\
$a_{j}\left(H_{\beta}\right)$ & 1,528 & $-1,551 e-5$ & $-3,462 e-9$ & 0,27 & Takáts \& Vinkó (2012) \\
$a_{j}\left(H_{\beta}\right)^{a}$ & 1,578 & $-8,573 e-5$ & $3,017 e-9$ & 0,17 & Takáts \& Vinkó (2012) \\
$a_{j}(\mathrm{Fe}$ II $\lambda 5169)$ & 1,641 & $-2,297 e-4$ & $1,751 e-8$ & 0,11 & Takáts \& Vinkó (2012) \\
\hline
\end{tabular}

${ }^{a}$ SN 2004et nélkül

Többek között Dessart \& Hillier (2005b) is megmutatta, hogy a Fe II $5169 \AA$ vonal minimumából mérhető sebesség szorosabb összefüggést mutat a fotoszferikus sebességgel, mint $v_{\mathrm{H} \beta}$. Az 5.3. ábrán is megfigyelhetô, hogy a $v_{\mathrm{Fe}} / v_{\text {modell }}$ arány idóbeli lefutása mindegyik SNre hasonló, míg az $v_{\mathrm{H} \beta} / v_{\text {modell }}$ arány esetében jelentős eltérések adódtak. Ebből kiindulva megismételtem az 5.1 összefüggés illesztését, viszont ezúttal $v_{\mathrm{H} \beta}$ helyett a $v_{\mathrm{Fe}}$ használatával. A szórás ekkor jelentősen lecsökkent ( $r m s ~ \sigma=0,111)$. Az illesztés során kapott $a_{j}$ értékeket szintén az 5.1. táblázat tartalmazza, míg maga az illesztett görbe az 5.4. ábra jobb oldali képén látható. Habár ez a szoros összefüggés azt mutatja, hogy mért $v_{\mathrm{Fe}}$ sebességekből $v_{\text {modell }}$ könnyen meghatározható, ez nem jelenti azt, hogy egyes szupernóvák esetében ne lehetnének jelentős eltérések.

Poznanski és mtsai (2010) az SDSS-II ${ }^{24}$ adatainak felhasználásával vizsgálták a kapcsolatot $\mathrm{H} \beta$ és az Fe II 5169 Å vonalak abszorpciós minimumából mérhető sebességek között. Azt találták, hogy ez egy lineáris összefüggéssel írható le: $v_{\mathrm{Fe}}=a \cdot v_{\mathrm{H} \beta}$, ahol $a=0,84 \pm 0,05$. $\mathrm{Az}$ általam mért $v_{\mathrm{Fe}}$ és $v_{\mathrm{H} \beta}$ sebességek felhasználásával megismételtem az illesztést, és az egyenes meredekségére $a=0,791 \pm 0,012(\sigma=0,146)$ értéket kaptam. Poznanski és mtsai (2010) csak a robbanást követő 40. napnál korábbi adatokat használta fel, így következő lépésben kihagytam az ennél későbbi pontokat és újra megismételtem az illesztést. Ekkor a meredekség $a=0,823 \pm 0,015(\sigma=0,102)$ lett, ami gyakorlatilag megegyezik a Poznanski és mtsai (2010) által kapott eredménnyel (5.5. ábra). Méréseim tehát megerősítik az általuk kapottakat, és kiegészítik azokat későbbi fázisokra.

Nugent és mtsai (2006) munkájuk során a sebességgörbe időbeli lefutását vizsgálták és azt találták, hogy $v_{\mathrm{Fe}}$ változása az alábbi görbével illeszthető:

$$
v_{\mathrm{Fe}}(t) / v_{\mathrm{Fe}}(50 \mathrm{~d})=(t / 50 \mathrm{~d})^{c}
$$

ahol $c=-0,464 \pm 0,017$. Ezt az illesztést az öt II-P SN általam mért $v_{\mathrm{Fe}}$ értékeire megismételve a kitevő $c=-0,663 \pm 0,010$ értékünek adódott. Mivel az SN 2005cs sebességgörbéje szembetúnôen különbözik a többiétôl (5.6. ábra) megismételtem úgy is az illesztést, hogy ennek az SN-nek az adatait nem vettem figyelembe. Ekkor a kitevő $c=-0,546 \pm 0,01$ értékûre módosult. Az illesztett görbe, a Nugent és mtsai (2006) által kapottal együtt az 5.6. ábrán látható. Az újonnan meghatározott kitevő csak kis mértékben $(\sim 1 \sigma)$ különbözik a Nugent és mtsai (2006) eredeti eredményétől. A különbség egyik oka lehet, hogy az én mintám

\footnotetext{
${ }^{24}$ SDSS-II Supernova Survey, http: //www.sdss.org/supernova/about supernova.html
} 


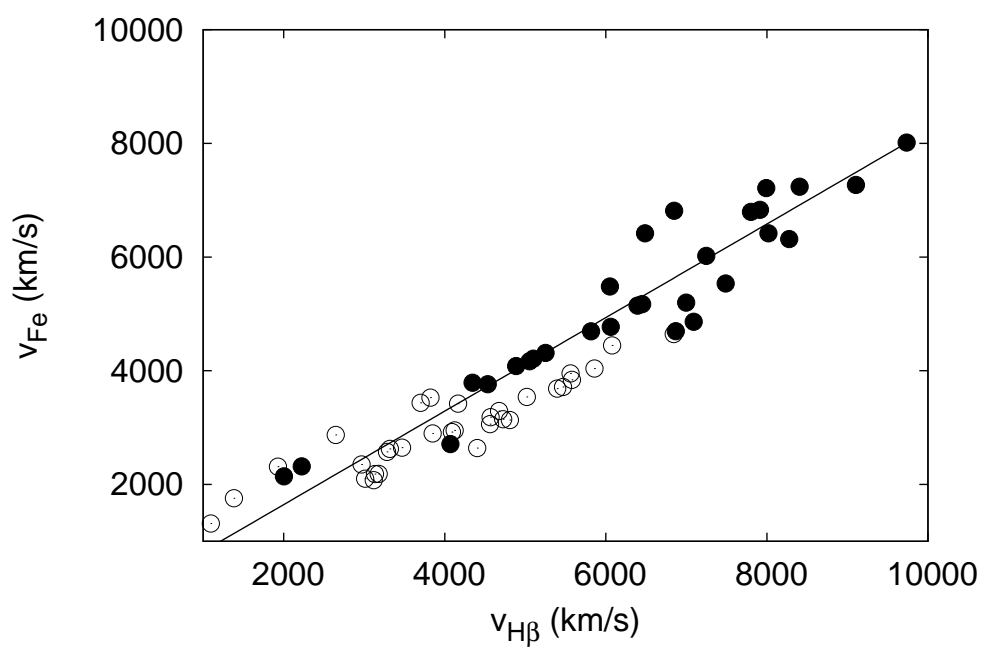

5.5. ábra. A $v_{\mathrm{Fe}}$ és $v_{\mathrm{H} \beta}$ sebességek között fennálló összefüggés. Az üres körök a 40. napnál későbbi adatokat jelentik, míg a teli körök az ennél korábbiakat. Az egyenes illesztését a 40. napnál korábbi adatokra végeztem.

a robbanást követô 13. és 104. nap közti időtartamot fedi le, míg Nugent és mtsai (2006) adatai a 9. és a 75. nap közé estek.

Megvizsgáltam azt is, hogy $v_{\text {modell }}$ időbeli lefutása hogyan írható le. Kombinálva az 5.1. és az 5.2. egyenletet, a következő összefüggést illesztettem az adatokra:

$$
v_{\text {modell }}(t) / v_{\text {modell }}(50 \mathrm{~d})=\frac{(t / 50)^{-0,210 \pm 0,110}}{\sum_{j=0}^{2} b_{j}(t / 50)^{j}}
$$

Az illesztés során az SN 2005cs adatait kihagytam, hiszen ennek sebességgörbéje jelentősen eltér a többiétől. A kapott illesztési paraméterek: $b_{0}=0,467 \pm 0,150, b_{1}=0,327 \pm 0,230$ és $b_{2}=0,174 \pm 0,110$. A szórás $\sigma=0,148$ értékúnek adódott. Az illesztett görbe az 5.6. ábrán látható. Az összefüggés felhasználásával lehetôvé válik egy gyengén mintavételezett SN sebességének extrapolációja más időpontokra (lásd pl. SN 2009N, Takáts és mtsai, előkészületben).

\subsection{A távolság és a távolságfüggó fizikai paraméterek}

A tágulási sebességeknek jelentős szerepe van a távolságmeghatározásban, akár az EPMet, akár az SCM-et használjuk (2.2., 2.3. fej.). Az előző fejezetkből kiderült, hogy az egyes módszerek használatával jelentősen eltérő sebességeket kapunk. A nem megfelelő módszer használata tehát pontatlan távolsághoz vezet.

A mintámban szereplő öt II-P típusú szupernóvának meghatároztam a távolságát mind az - irodalomban leggyakrabban használt $-v_{\mathrm{Fe}}$, mind a kapott $v_{\text {modell }}$ sebességek felhasználásával (Takáts \& Vinkó, 2012). Az eredmények ismertetése és összehasonlítása a szülőgalaxisok korábban, más módszerekkel meghatározott távolságával részletesen szerepel a 4. fejezetben. Az 5.2. táblázat összefoglalja a kétféle sebességgel kapott eredményeket. Két 

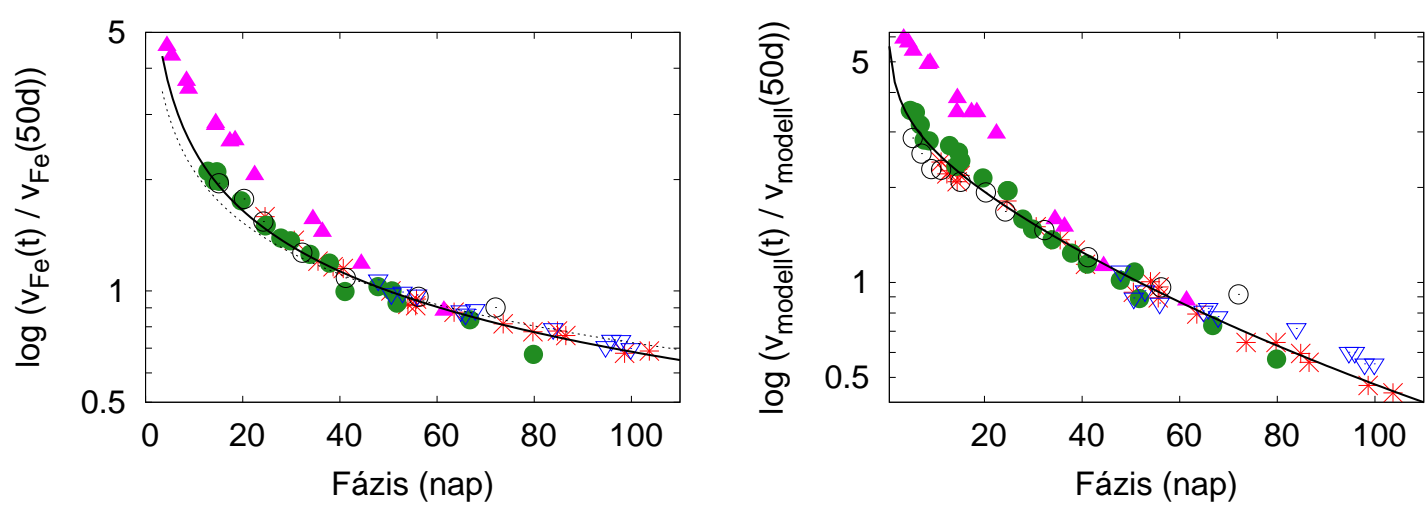

5.6. ábra. A $v_{\mathrm{Fe}}$ és $v_{\text {modell }}$ sebességek időbeli lefutása. A bal oldali ábrán a szaggatott vonal a Nugent és mtsai (2006) által meghatározott görbét mutatja, míg a folytonos görbét az általam vizsgált öt SN adataira végzett illesztés során kaptam (Takáts \& Vinkó, 2012). Mind a két féle sebesség esetén az SN 2005cs adatait (rózsaszín háromszögek) kihagytam az illesztésből. Az egyes szimbólumok a különböző szupernóvákat jelentik az 5.1. ábránál leírtak szerint.

5.2. táblázat. Az öt, II-P típusú szupernóva EPM-mel meghatározott távolsága a v modell valamint a $v_{\mathrm{Fe}}$ sebességek felhasználásával.

\begin{tabular}{lccc}
\hline SN & \multicolumn{2}{c}{ Távolság $(\mathrm{Mpc})$} & Forrás $^{a}$ \\
& $v_{\text {modell }}$ & $v_{\mathrm{Fe}}$ & \\
\hline 1999em & $12,5(1,4)$ & $9,7(0,8)$ & $1,2,3$ \\
2004dj & $3,6(0,6)$ & $3,7(0,8)$ & 4,5 \\
2004et & $4,8(0,4)$ & $4,8(0,6)$ & 6,7 \\
2005cs & $8,6(0,2)$ & $7,5(0,2)$ & 8 \\
2006bp & $20,7(1,8)$ & $18,6(1,5)$ & 9 \\
\hline
\end{tabular}

${ }^{a}$ A fotometriai adatok forrása: (1) Hamuy és mtsai (2001), (2) Leonard és mtsai (2002),

(3) Elmhamdi és mtsai (2003), (4) Vinkó és mtsai (2006), (5) Tsvetkov és mtsai (2008),

(6) Maguire és mtsai (2010b), (7) Sahu és mtsai (2006), (8) Pastorello és mtsai (2009),

(9) Dessart és mtsai (2008) 
5.3. táblázat. A vizsgált II-P típusú szupernóvák távolsága $(D)$, a plató fázis időbeli hossza $\left(t_{p}\right)$, valamint a $V$ szúrős abszolút magnitúdó $\left(M_{V, p}\right)$ és tágulási sebesség $\left(v_{p}\right)$ a plató közepén. Mindegyik SN esetében a felsô sor az általam kapott értékeket mutatja, míg az alsó sorban mások eredményei ${ }^{b}$ láthatók.

\begin{tabular}{lccccc}
\hline SN & $\begin{array}{c}\mathrm{D} \\
(\mathrm{Mpc})\end{array}$ & $\begin{array}{c}M_{V, p} \\
(\mathrm{mag})\end{array}$ & $\begin{array}{c}t_{p} \\
(\mathrm{nap})\end{array}$ & $\begin{array}{c}v_{p} \\
\left(\mathrm{kms}^{-1}\right)\end{array}$ & Forrás \\
\hline \multirow{2}{*}{ 1999em } & $12,5(1,4)$ & $-16,84(0,24)$ & $120(10)$ & $2520(300)$ & \\
& $11,7(1,0)$ & $-16,68(0,27)$ & $120(10)$ & $3046(150)$ & 1 \\
& & & & & \\
$2004 \mathrm{dj}$ & $3,6(0,6)$ & $-16,35(0,36)$ & $105(20)$ & $2710(300)$ & \\
& $3,3(0,3)$ & $-16,16(0,23)$ & $105(20)$ & $2957(150)$ & 1 \\
& & & & & \\
$2004 \mathrm{et}$ & $4,8(0,4)$ & $-16,70(0,18)$ & $110(15)$ & $3650(350)$ & \\
& $5,9(0,4)$ & $-17,15(0,27)$ & $110(15)$ & $3462(150)$ & 1 \\
& & & & & \\
$2005 \mathrm{cs}^{a}{ }^{a}$ & $8,4(0,7)$ & $-15,03(0,17)$ & $118(15)$ & $1430(200)$ & \\
& $7,1(1,2)$ & $-14,66(0,39)$ & $118(15)$ & $1500(150)$ & 1 \\
& & & & & \\
$2006 \mathrm{bp}$ & $20,7(1,8)$ & $-17,35(0,20)$ & $90(20)$ & $4800(200)$ & \\
& $17,5(0,8)$ & $-16,98(0,20)$ & $90(20)$ & $4150(300)$ & 2 \\
\hline
\end{tabular}

${ }^{a} \mathrm{Az}$ SN 2005cs esetében azt a távolságot használtam, amelyet ennek és az SN 2011dh adatainak kombinálásával kaptunk.

${ }^{b}$ Forrás: (1) Maguire és mtsai (2010b), (2) Dessart és mtsai (2008).

szupernóva, az SN 2004dj és az SN 2004et esetében mindkét sebesség hasonló távolságot eredményezett. A másik három objektumnál viszont a $v_{\text {modell }}$ használatával jelentôsen nagyobb távolságokat kaptunk, mint a $v_{\mathrm{Fe}}$-vel. Az SN 1999em és SN 2005cs esetében végeztek korábban távolságmérést SEAM-mal, illetve NLTE modellek felhasználásával. Az ezekkel

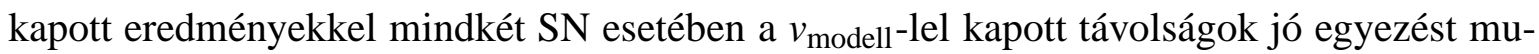
tattak, míg $v_{\mathrm{Fe}}$ használata jóval kisebb értékekhez vezetett (4.3. és 4.10. táblázat).

A fotoszferikus sebesség meghatározására jelenleg az NLTE modellek létrehozása a legpontosabb módszer (2.2.2. fej.). Azonban ez jelentős számítási kapacitást igényel, ezért ha csupán a sebességmeghatározás a cél, túlságosan időigényes. A SYNOW modellek illesztésével történő sebességmérés ugyanakkor ezekhez képest $\sim 10 \%$-on belül azonos eredményeket szolgáltat (5.1. ábra). Felhasználása az EPM során pedig olyan távolságokhoz vezet, amelyek jó egyezést mutatnak azokkal, amelyeket a kifinomultabb, ám lassabb módszerek szolgáltatnak.

A távolság ismerete rendkívül fontos ahhoz, hogy meghatározzuk a szupernóvák - és természetesen bármely más csillagászati objektum - fizikai tulajdonságait, és ezen keresztül megértsük a végbemenő folyamatokat. Az SN-k abszolút fényességének ismerete már önmagában sokat elárul természetükről, de felhasználásával - és különböző hidrodinamikai modellek eredményeinek segítségével - más paraméterekre értékére is következtethetünk.

A nebuláris fázisban mért luminozitás $\left(L_{n e b}\right)$ ismeretében a keletkezett ${ }^{56} \mathrm{Ni}$ tömege ki- 
számolható például a Hamuy (2003) által felállított összefüggés segítségével:

$$
M_{\mathrm{Ni}}=\left(7,866 \times 10^{-44}\right) L_{\mathrm{neb}}(t) \exp \left(\frac{\left(t-t_{0}\right) /(1+z)-6,1}{111,26}\right),
$$

ahol 6,1 nap a ${ }^{56} \mathrm{Ni}$ felezési ideje, 111,25 nap a ${ }^{56}$ Co bomlási állandója.

A luminozitás meghatározásához ideális esetben nagy hullámhossztartományt lefedô mérésekre van szükség, ugyanis az így kapott fluxusok integrálása megadja a bolometrikus fluxus nagyságát, amelyből a távolság ismeretében a luminozitást kiszámolható. Amennyiben ilyen mérések nem állnak rendelkezésünkre, más közelítő módszerekhez is folyamodhatunk. A nebuláris fázisban mért luminozitás kiszámítható a $V$ szúrővel mért magnitúdóból $\left(m_{V}\right)$ a bolometrikus korrekció (BC) ismeretében:

$$
\lg L_{\mathrm{neb}}=\frac{-\left(m_{V}+B C\right)+5 \lg D-8,14}{2,5}
$$

A bolometrikus korrekció értékét meg lehet határozni olyan szupernóvák segítségével, amelyekről jó minôségú és időbeli lefedettségú, UV, optikai és NIR szűrôvel készült fénygörbék állnak rendelkezésre, így a luminozitásuk pontosan megkapható. Hamuy (2003) az SN 1987A és az SN 1999em ilyen jellegú adatsorának felhasználásával a bolometrikus korrekció értékére $B C=0,26 \pm 0,6$ magnitúdót kapott, míg Maguire és mtsai (2010b) az SN 1987A, az SN 1999em, az SN 2004et és az SN 2005cs adataiból némileg különböző, $B C=0,33 \pm$ 0,06 magnitúdót határoztak meg. A két eredmény közti eltérést Maguire és mtsai (2010b) azzal magyarázták, hogy a két csoport a szupernóvák bolometrikus luminozitását kissé eltérő módszerrel számolta ki.

Az SN 1999em, 2004dj, 2004et és 2005cs esetében az általam kapott, $v_{\text {modell }}$ sebességek felhasználásával meghatározott új távolságok segítségével, a fenti összefüggést alkalmazva kiszámoltam $L_{\text {neb }}$ értékét (mindkét csoport $B C$ értékét felhasználtam, és az eredményeket átlagoltam), majd ebből a keletkezett ${ }^{56} \mathrm{Ni}$ tömegét. Az SN 2011dh-ról nem állnak rendelkezésre nebuláris fázisban készült mérések, míg az SN 2006bp-rôl csak - meglehetősen pontatlan - szû́rô nélküli adatok találhatóak meg, így ezeket esetében a nikkeltömeget nem lehetett meghatározni. A kapott eredmények, a korábban, mások által meghatározott értékekkel összevetve az 5.4. táblázatban találhatóak.

A Litvinova \& Nadezhin (1983) által számolt hidrodinamikai modellek fehasználásával Litvinova \& Nadezhin (1985) olyan összefüggéseket állított fel, amelyek segítségével a II-P típusú szupernóvák robbanásának néhány paramétere becsülhetô, ha ismerjük a plató fázis időtartamát $\left(t_{\mathrm{p}}\right)$ valamint a plató fázis közepén mérhetô abszolút fényességet $\left(M_{V, \mathrm{p}}\right)$ és tágulási sebességet $\left(v_{\mathrm{p}}\right)$. Az így kiszámolható paraméterek: a robbanás energiája $\left(E_{\text {exp }}\right)$, a csillag sugara a robbanást megelőzôen $\left(R_{\mathrm{ini}}\right)$ és a ledobódott burok tömege $\left(M_{\mathrm{ej}}\right)$ :

$$
\begin{aligned}
\lg E_{\text {exp }} & =0,135 \cdot M_{V, \mathrm{p}}+2,34 \cdot \lg t_{\mathrm{p}}+3,13 \cdot \lg \left(v_{\mathrm{p}} / 1000\right)-4,205 \\
\lg R_{\text {ini }} & =-0,572 \cdot M_{V, \mathrm{p}}-1,07 \cdot \lg t_{\mathrm{p}}-2,74 \cdot \lg \left(v_{\mathrm{p}} / 1000\right)-3,350 \\
\lg M_{\mathrm{ej}} & =0,234 \cdot M_{V, \mathrm{p}}+2,91 \cdot \lg t_{\mathrm{p}}+1,96 \cdot \lg \left(v_{\mathrm{p}} / 1000\right)-1,829
\end{aligned}
$$

A dolgozatban szereplő öt II-P típusú szupernóva esetében ezeket az összefüggéseket felhasználva kiszámoltam a fenti paramétereket (5.3. táblázat). Ugyanezekre a szupernóvákra, az SN 2006bp kivételével, Maguire és mtsai (2010b) már elvégezte ezeket a számolásokat, 
5.4. táblázat. Az öt II-P típusú szupernóva néhány, az (5.4) és (5.6) összefüggések segítségével, az 5.3. táblázat adataiból számolt fizikai tulajdonsága. Hasonlóan, mint a 5.3. táblázatban, minden SN esetében a felsố sor az újonnan, $v_{\text {modell }}$ sebesség felhasználásával kapott távolságokból számolt értékeket tartalmazza, míg az alsó sor a korábbi munkákban kapottakat mutatja.

\begin{tabular}{|c|c|c|c|c|c|}
\hline SN & $\begin{array}{c}E_{\exp } \\
\left(10^{51} \mathrm{erg}\right)\end{array}$ & $\begin{array}{c}R_{\text {ini }} \\
\left(\mathrm{R}_{\odot}\right)\end{array}$ & $\begin{array}{c}M_{\mathrm{ej}} \\
\left(\mathrm{M}_{\odot}\right)\end{array}$ & $\begin{array}{c}M_{\mathrm{Ni}} \\
\left(10^{-2} \mathrm{M}_{\odot}\right)\end{array}$ & Forrás $^{a}$ \\
\hline \multirow{2}{*}{$1999 \mathrm{em}$} & $0,44(0,27)$ & 907 (400) & $11,7(5,6)$ & $5,8(1,2)$ & \\
\hline & $0,84(0,29)$ & 437 (173) & $18,0(7,0)$ & $2,2-3,6$ & $1,2,3$ \\
\hline \multirow{2}{*}{ 2004dj } & $0,47(0,39)$ & $449(240)$ & $11,9(6,8)$ & $1,6(0,4)$ & \\
\hline & $0,65(0,30)$ & 277 (107) & $16,0(9,0)$ & $1,3-2,3$ & $1,4,5,6,7$ \\
\hline \multirow{2}{*}{2004 et } & $1,19(0,76)$ & $300(131)$ & $20,2(12,8)$ & $4,1(0,8)$ & \\
\hline & $0,88(0,31)$ & $631(250)$ & $14,0(6,0)$ & $5,6-6,8$ & $1,8,9,10,11$ \\
\hline \multirow{2}{*}{$2005 \mathrm{cs}$} & $0,13(0,09)$ & 402 (337) & $9,7(5,9)$ & $0,22(0,07)$ & \\
\hline & $0,17(0,08)$ & $208(123)$ & $13,0(6,0)$ & $0,3-0,9$ & $1,12,13$ \\
\hline \multirow{2}{*}{$2006 b p$} & $1,43(0,90)$ & $413(120)$ & $13,6(9,0)$ & - & \\
\hline & $0,99(0,50)$ & 379 (130) & $12,5(8,0)$ & - & 14 \\
\hline
\end{tabular}

${ }^{a}$ Az összehasonlításként feltüntetett adatok forrása: (1) Maguire és mtsai (2010b), (2) Elmhamdi és mtsai (2003), (3) Utrobin (2007), (4) Kotak és mtsai (2005), (5) Chugai és mtsai (2005), (6) Zhang és mtsai (2006), (7) Vinkó és mtsai (2006), (8) Sahu és mtsai (2006), (9) Misra és mtsai (2007), (10) Utrobin \& Chugai (2009), (11) Maguire és mtsai (2010b), (12) Takáts \& Vinkó (2006), (13) Utrobin \& Chugai (2008), (14) az 5.3. táblázat adataiból általam számolt értékek.

más $D$ és $v_{\mathrm{p}}$ értékek felhasználásával (ezek szintén megtalálhatóak az 5.3. táblázatban). Öszszehasonlításképpen az általuk kapott eredményeket is feltüntettem az 5.4. táblázatban, az általam meghatározott értékek mellett. Az (5.6) - (5.8) egyenletek alkalmazása során a paraméterek kis mértékú megváltoztatása is jelentôsen befolyásolja az eredményeket. Ez meg is jelenik az ezekre a szupernóvákra kapott értékek esetében, hiszen az általam kapottak minden esetben jelentősen különböznek a Maguire és mtsai (2010b) által meghatározottaktól. Ugyanakkor meg kell említeni, hogy ezen összefüggések használatakor a hiba mértéke is jelentôs.

A szupernóvák távolságának mérése - az egyedi objektumok fizikai tulajdonságainak tanulmányozásán kívül - a kozmológiai modellek teszteléséhez, finomításához is jelentősen hozzájárult és járulhat még hozzá a jövőben is. Ahogy már az 1.3 fejezetben is volt róla szó, az Ia típusú szupernóvák vizsgálata és távolságuk meghatározása vezetett annak bizonyításához, hogy az Univerzum gyorsulva tágul. Ugyanakkor az alkalmazott távolságmérési eljárások tapasztalati tényeken alapulnak, tudásunk ezekrôl az objektumokról még meglehetősen korlátozott. Ezért a segítségükkel kapott eredmények ellenőrzése és pontosítása 


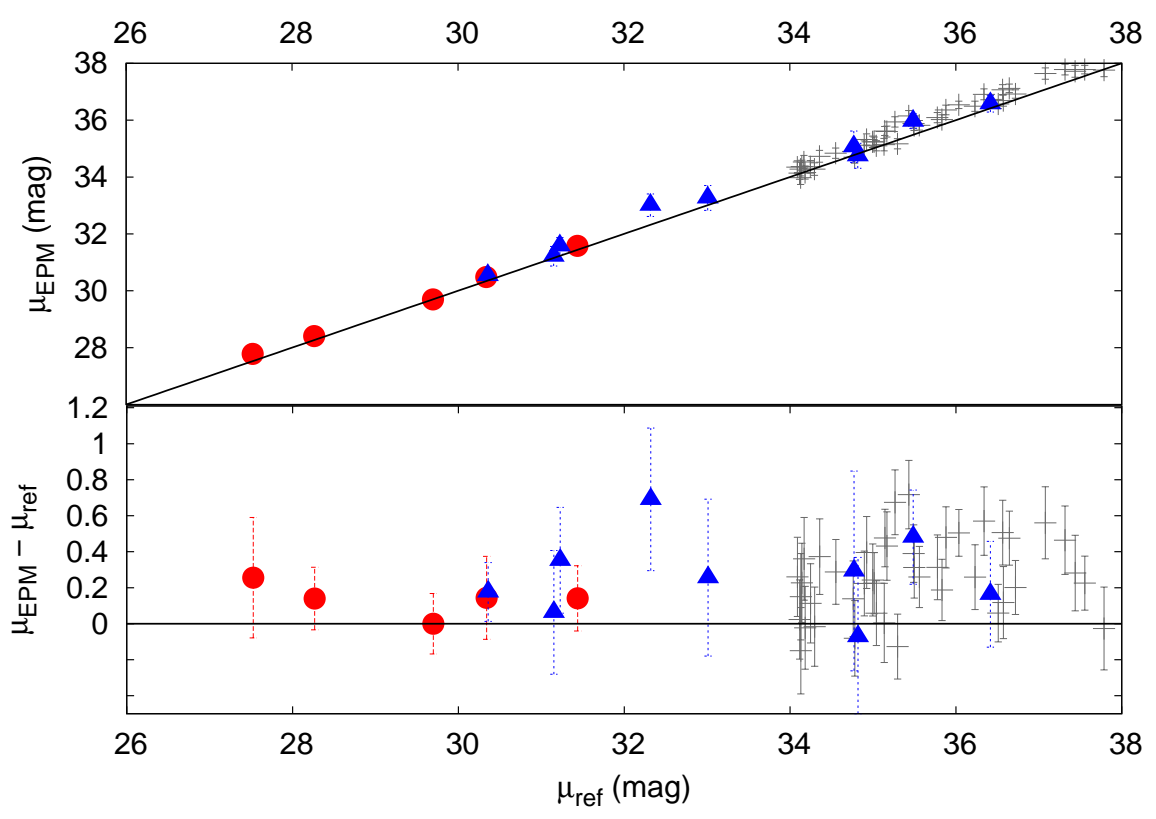

5.7. ábra. A dolgozatban szereplő öt szupernóva (piros) és a Vinkó \& Takáts (2007) mintájában szereplő SN-k (kék) EPM-mel kapott távolságának összehasonlítása a galaxisuk vöröseltolódásából meghatározott távolsággal, együtt néhány közeli Ia adatával (szürke). Az alsó ábra a két távolság különbségét mutatja.

más módszerekkel elengedhetetlen.

Mivel az EPM olyan módszer, amelyhez nem szükséges kalibráció, ez az egyik legígéretesebb jelölt az Ia-kkal kapott eredmények független ellenôrzésére. Az 5.7. ábrán látható Hubble-diagramon az EPM-mel kapott távolságokat hasonlítom össze a szupernóvák galaxisának vöröseltolódásából ( $z$ ) meghatározott távolságokkal. Utóbbiakat a $D=c z / H_{0}$ összefüggés felhasználásával számoltam ki, ahol $c$ a fénysebesség, $H_{0}=73 \mathrm{kms}^{-1} \mathrm{Mpc}^{-1}$ pedig a Hubble-állandó (Riess és mtsai, 2005). A dolgozatban szereplő öt SN (piros) mellett szerepel Vinkó \& Takáts (2007) mintája is (kék). Előbbiek esetében az EPM távolság kiszámításakor $v_{\text {modell }}$, utóbbiaknál $v_{\mathrm{Fe}}$ sebességet vettem figyelembe. Az ábrán feltüntettem még néhány kis vöröseltolódású Ia típusú szupernóvát is ${ }^{25}$, amelyek esetében a referencia távolság szintén a galaxis vöröseltolódásából származik (Wood-Vasey és mtsai, 2007), míg az $y$ tengelyen az MLCS2K2 és a SALT2 módszerek eredményeinek kombinációját tüntettem fel (Davis és mtsai, 2007; Riess és mtsai, 2007). Az 5.7. ábra alsó képén a referencia- és a szupernóvákkal kapott távolságok különbsége látható. Megfigyelhető, hogy a II-P SN-k EPM-mel meghatározott távolsága nem mutat nagyobb szórást, mint az Ia szupernóvákkal kapott eredmények. Az EPM tehát már jelenleg is eléggé megbízható, és ahogy a II-P szupernóvákról rendelkezésre álló ismereteink bővülnek, a módszer egyre pontosabbá válik, így a közeljövőben lehetőség lesz arra, hogy egyre nagyobb vöröseltolódású szupernóvákra terjesszük ki alkalmazását.

\footnotetext{
${ }^{25}$ Forrás: http://braeburn.pha.jhu.edu/ ariess/R06/Davis07_R07_WV07.dat
} 


\section{Összefoglalás}

A szupernóvák kutatása az utóbbi évtizedekben a csillagászat egyik leggyorsabban fejlôdő területévé vált. A dedikált felfedezőprogramoknak köszönhetően számuk évrôl évre nő, ismereteink egyre gyarapodnak, eközben újra és újra találnak olyan objektumot, mely nem illeszkedik egyértelmúen a szokásos kategóriákba. Ugyanakkor a régóta ismert típusokkal kapcsolatban is sok a megválaszolatlan kérdés, mind szülőcsillagaik természetérôl, mind a robbanás fizikájáról és az utána végbemenő folyamatokról. Dolgozatom elsô felében áttekintettem a szupernóvák csoportosítását, az egyes típusokról rendelkezésre álló legfontosabb ismereteket, ezek legfőbb fizikai tulajdonságait.

A szupernóváknak jelentős szerepe van az extragalaktikus távolságmérésben. Elsősorban az Ia típusúakat használják erre a célra, segítségükkel sikerült bebizonyítani, hogy az Univerzum gyorsulva tágul. Ezért az eredményért a Brian Smith, Adam Riess és Saul Perlmutter megkapták a 2011-es fizikai Nobel-díjat. Ugyanakkor a használt módszerek empirikus korreláción alapulnak, és - ahogy azt Vinkó és mtsai (2012b) is megmutatták - az egyes eljárások nem adnak teljesen konzisztens eredményt.

Az Ia-kon kívül a II-P típusú szupernóvákat is használhatjuk távolságmérésre. Jelenleg két módszer áll rendelkezésre, a táguló fotoszféra módszer (EPM; 2.2. fej.) és a standard gyertya módszer (SCM; 2.3. fej.). Az EPM használatához nincs szükség kalibrációra, más módszerektôl független távolságot ad. Viszont alkalmazásához minél több, korai, jó minőségú fotometriai és spektroszkópiai adatra van szükség. Az SCM a plató közepén mért fényesség és tágulási sebesség között fennálló empirikus összefüggésen alapul, tehát kalibrálni kell ismert távolságú szupernóvák segítségével. Ugyanakkor használatához kevesebb adatra van szükség, mint az EPM esetében.

Mindkét távolságmérési eljárás használata során fontos a fotoszféra tágulási sebességének minél pontosabb ismerete. Ennek mérésére több módszert is kipróbáltak a korábbi munkákban. A leggyakrabban alkalmazott eljárás bizonyos vonalak abszorpciós minimuma Doppler-eltolódásának mérése. Általában az Fe II 5169 Å vonalát használják erre a célra. Azonban többek között Dessart \& Hillier (2005b) megmutatták, hogy az így mért sebesség nem egyezik meg a fotoszféra sebességével, attól való eltérése fázisfüggő, ráadásul szupernóváról szupernóvára is változik. Többen, köztük Poznanski és mtsai (2009) a keresztkorrelációs technika alkalmazásával próbálkoztak, de ez a módszer a P Cygni vonalprofil esetében meglehetősen pontatlan. Így használata esetleg olyankor lehet indokolt, amikor rossz jel/zaj viszonyú spektrumunk van.

A fotoszferikus sebesség mérésére a legjobb módszer a spektrum NLTE modellezése. Ez azonban nagy számítási kapacitást igényel, így sok spektrum esetében alkalmazása túl időigényes, eddig csak néhány objektum esetében végeztek ilyen számolásokat. A szupernóvák spektrumának modellezésére azonban léteznek sokkal egyszerúbb, LTE közelí- 
tést alkalmazó programok is, ilyen például a SYNOW nevú kód. Munkám során az ezzel történő sebességmeghatározást vizsgáltam. Ehhez öt olyan II-P típusú szupernóvát használtam, melyek mindegyikéről nagy mennyiségú, publikus adat állt rendelkezésre, és amelyek többségét korai fázisban fedezték fel. Az öt SN (1999em, 2004dj, 2004et, 2005cs és 2006bp) plató fázisában felvett spektrumait modelleztem a SYNOW-val, és a H $\beta$ illetve az Fe II 5169 Å vonal illesztésével megmértem a fotoszferikus sebességüket ( $\left.v_{\text {modell }}\right)$.

Összehasonlításként más módszerekkel is meghatároztam a sebességeket: megmértem a $\mathrm{H} \beta$ valamint az Fe II 5169 Å vonalak minimumának Doppler-eltolódását ( $v_{\mathrm{H} \beta}$ és $v_{\mathrm{Fe}}$ ), illetve két különböző készletet használva keresztkorreláció alkalmazásával is végeztem sebességmérést $\left(v_{\mathrm{cc}}\right)$. Ezenkívül három szupernóva (SN 1999em, 2005cs és 2006bp) esetében a Dessart \& Hillier (2006) és Dessart és mtsai (2008) által a CMFGEN nevú NLTE modellezőprogrammal kapott $v_{\text {nlte }}$ sebességek is rendelkezésre álltak. A különböző módszerekkel kapott sebességek összehasonlítása azt mutatta, hogy a SYNOW-val történô modellezés a $v_{\text {nlte }}$ sebességekkel $\sim 10 \%$-on belül egyező eredményeket ad. Ugyanakkor a vonalminimumok helyéből meghatározott és a keresztkorrelációval kapott sebességek jelentôs eltéréseket

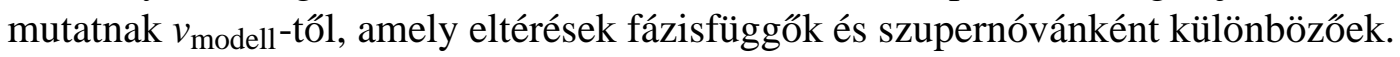

A mérési eredményekre történô görbeillesztéssel megállapítottam azokat az összefüggéseket, amelyek segítségével $v_{\mathrm{H} \beta}$ illetve $v_{\mathrm{Fe}}$ értékéből következtetni lehet $v_{\text {modell }}$ nagyságára. Mivel azonban a sebességek aránya szupernóvánként eltéró, $v_{\text {modell }}$ ilyen módon történő megállapítása jelentős hibával terhelt. Megvizsgáltam a $v_{\mathrm{Fe}}$ illetve a $v_{\text {modell }}$ sebességek időbeli lefutását is, és meghatároztam az ezeket leíró összefüggéseket. Az EPM alkalmazásához ugyanis egyidejú fotometriai és spektroszkópiai mérésekre van szükség, ám ennek gyakorlati megvalósítása nem mindig lehetséges. Ilyenkor vagy a fényesség-, vagy a sebességgörbe adatait kell interpolálni a másik adatsor időpontjaira. Az megállapított összefüggések az utóbbit teszik lehetôvé.

A meghatározott sebességek felhasználásával ezután kiszámítottam a mintában szereplő öt szupernóva távolságát az EPM alkalmazásával. Ezt mind a $v_{\mathrm{Fe}}$, mind a $v_{\text {modell }}$ sebességekkel megtettem, így össze tudtam hasonlítani a két sebességgel kapott eredményeket. Az SN 2004dj és az SN 2004et esetében mindkettővel egyforma távolságokat kaptam, míg a másik három szupernóvánál $v_{\text {modell }}$ használata nagyobb távolságokat eredményezett, mint $v_{\mathrm{Fe}}$ figyelembevétele. A távolságokat a korábban, mások által meghatározott értékekkel is

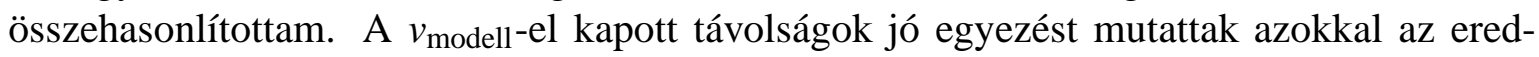
ményekkel, amelyeket pl. SEAM-mal, vagy az EPM CMFGEN modellek felhasználásával történő alkalmazása során kaptak, illetve az SN 1999em esetében a galaxisban található cefeidák segítségével kapott távolsággal.

A SYNOW-val történő spektrummodellezést és sebességmérést elvégeztem egy újabb, IIb típusú SN esetében is. Az SN 2011dh az M51 jelú galaxisban bukkant fel, ugyanabban, mint korábban az SN 2005cs. Mindkét szupernóvát rendkívül korai fázisban fedezték fel, ezért robbanásuk időpontját nagyon pontosan meg lehetett határozni. Így lehetségessé vált a két szupernóva adatainak kombinálása, és - a v modell sebességek felhasználásával - távolságuk együttes meghatározása (Vinkó és mtsai, 2012a).

A távolságok ismerete fontos a szupernóvák fizikai tulajdonságának megméréséhez. Az öt II-P típusú SN esetében a meghatározott távolságok segítségével kiszámoltam a robbanás során keletkezett ${ }^{56} \mathrm{Ni}$ tömegét, a robbanás energiáját, a ledobódott burok tömegét és a szülő́csillag robbanás előtti sugarának nagyságát. Ezeknek az értékét aztán összeha- 
sonlítottam mások által, korábban kapott értékekkel.

Az öt szupernóva EPM-mel meghatározott távolságát a Hubble-diagramon is ábrázoltam, együtt más II-P és Ia típusú SN-k adataival. Az EPM eredményei nem mutatnak nagyobb eltérést a galaxisok vöröseltolódásából számolt távolságoktól, mint az Ia SN-k adatai, ami jelzi, hogy a módszer elég megbízható távolságot szolgáltat. Ezért a jövőben az EPM kiterjesztése távolabbi SN-kre ígéretes lehetőség az Ia-kal kapott eredmények független ellenőrzésére 


\section{Summary}

In the last decades supernova research has become one of the most dynamically developing fields of astronomy. Surveys dedicated to find new transients lead to the discovery of more and more SNe every year, some of which does not fit into any of the known categories. In the meantime many open questions exist about the classic types, too, about the nature of their progenitors, and the ongoing physical proccesses during and after the explosion. In the first half of my dissertation I review the classification of SNe, and describe the most important properties of each type.

Supernovae play an important role in measuring extragalactic distances. Mainly type Ia $\mathrm{SNe}$ are used for this purpose. They were used to prove that the expansion of the Universe is accelerating. For this result, the Nobel-prize was awarded to Brian Smith, Adam Riess and Saul Perlmutter in 2011. However, the applied methods are based on empirical correlations and - as it was shown by Vinkó et al. (2012b) - the absolute distances provided by different methods still suffer from systematic errors at the $10-15 \%$ level, so there is place for improvement.

Type II-P SNe can also be used for distance measurement. There are two possible techniques: the expanding photosphere method (EPM, Sec. 2.2) and the standardized candle method (SCM, Sec. 2.3). The usage of EPM requires photometric and spectroscopic monitoring throughout the plateau phase, starting at a very early phase. The advantage of EPM is that it does not need calibration using objects with known distances, it provides independent distances. SCM requires less input data than EPM, but it is based on an empirical correlation between the luminosity and the expansion velocity in the middle of the plateau phase, thus external calibration is necessary.

Both methods rely on the precise measurement of the expansion velocity. Determining its value is not trivial. The usual approach is to measure the Doppler shift of the absorption minima of certain lines, mostly the Fe II $5169 \AA$ or the $\mathrm{H} \beta\left(v_{\mathrm{abs}}\right)$. Among others, Dessart $\&$ Hillier (2005b) showed, that $v_{\text {abs }}$ either over- or underestimates the photospheric velocity, and the difference is phase-dependent. Several authors (e.g. Poznanski et al., 2009) proposed the application of the cross-correlation technique. However, this method is not entirely applicable in case of spectra with P Cyg line profiles, its usage can be justified for low S/N spectra, but the results will be heavily biased.

Building full NLTE models of the observed spectra and adopting its theoretical photospheric velocity is probably the most self-consistent technique so far. This method however requires a large amount of computing power, so its application for a great number of spectra is time-consuming and impractical. This approach was used only for a small sample of SNe so far. The basics of this method can be adopted using much simpler, parametrized modeling codes such as SYNOW. During my work I examined the applicability of SYNOW for mea- 
suring velocities. I selected five type II-P SNe (1999em, 2004dj, 2004et, 2005cs, 2006bp), that have well-sampled, good quality, publicly available data throughout plateau phase. I created SYNOW models of the spectra of the SNe, and by fitting the wavelength ranges of $\mathrm{H} \beta$ or Fe II $5169 \AA$ Å lines I determined their expansion velocities ( $\left.v_{\text {modell }}\right)$.

In order to compare the different methods, I also determined the velocities with other techniques. I measured the Doppler shift of the absorption minima of $\mathrm{H} \beta$ and $\mathrm{Fe}$ II $5169 \AA\left(v_{\mathrm{H} \beta}\right.$ and $\left.v_{\mathrm{Fe}}\right)$. Cross-correlation of the spectra with two separate template sets provided the $v_{\mathrm{cc}}$ values. In the case of three SNe (1999em, 2005cs and 2006bp) Dessart \& Hillier (2006) and Dessart et al. (2008) created NLTE models of the spectra using the CMFGEN code, and determined the photospheric velocities $\left(v_{\text {nlte }}\right)$. Modeling with SYNOW gives velocities that agree with $v_{\text {nlte }}$ within $10 \%$. The values $v_{\text {abs }}$ and $v_{\mathrm{cc}}$ differ from $v_{\text {modell }}$ and this difference is phase-dependent and changes from one SN to the other.

Correlations were determined between $v_{\text {modell }}$ and $v_{\text {abs }}$. Since their ratio is different for each $\mathrm{SN}$, calculating $v_{\text {modell }}$ based on these equations can lead to significant errors. I also examined the temporal evolution of $v_{\mathrm{Fe}}$ and $v_{\text {modell }}$. EPM requires contemporaneous photometric and spectroscopic data, but in most cases it is hard to achieve. A possible solution is the interpolation of either the velocity- or the light curve. The determined equations make the previous option possible.

Applying EPM, I calculated the distances of the five SNe using both $v_{\text {modell }}$ and $v_{\mathrm{Fe}}$ and then I compared the results. For SNe 2004dj and 2004et both velocities led to the same results, while in the case of the other three $\mathrm{SNe}$, the usage of $v_{\text {modell }}$ provided significantly longer distances. I also compared these results to distances from previous works. The $v_{\text {modell }}$ distances are in good agreement with those obtained using SEAM or EPM with the help of CMFGEN spectrum models, and in the case of SN 1999em, with the cepheid distance of the host galaxy.

SYNOW modeling and velocity measurement was also applied in the case of a type IIb supernova. SN 2011dh appeared in M51, the same galaxy that hosted SN 2005cs. Both SNe were discovered at very early phase, and in both cases the epoch of explosion was determined precisely, which made it possible to combine the data of the two objects and calculate the distance (Vinkó et al., 2012a).

In order to determine the physical parameters of $\mathrm{SNe}$, the knowledge of their distances is crucial. I calculated the ${ }^{56} \mathrm{Ni}$ mass, the explosion energy, the ejecta mass and the initial radius of the five type II-P SNe, using the distances calculated with $v_{\text {modell }}$, then I compared these values with the those from previous works.

I plotted the EPM distances of the five SNe on a Hubble-diagram together with other type II and Ia SNe. The results with EPM do not show higher scatter than those from Ia SNe, EPM provides consistent and reliable distances. In the future, extending the usage of EPM to higher redshifts can be a useful tool to test the distances of Ia SNe independently. 


\section{Köszönetnyilvánítás}

Köszönettel tartozom témavezetőmnek, Dr. Vinkó Józsefnek az évek során nyújtott segítségéért, útmutatásáért, türelméért és rengeteg munkájáért. Szeretnék köszönetet mondani Dr. Szabados Lászlónak a dolgozat átnézésért és hasznos javaslataiért. Köszönöm Szakáts Róbertnek és Szúcs Lászlónak az általuk nyújtott technikai segítséget.

Köszönet illeti az SZTE csillagász munkatársait és az SZTE Optikai és Kvantumelektronikai Tanszék vezetését és munkatársait a munkámhoz szükséges körülmények megteremtéséért.

Szeretném megköszönni családom minden tagjának a rengeteg támogatást és segítséget.

Kutatásaimhoz a következó pénzügyi támogatók nyújtottak segítséget: OTKA T042509 és K76816, Magyar Állami Eötvös Ösztöndíj, TÁMOP 4.2.2/B-10/1-2010-0012 


\section{Táblázatok jegyzéke}

1.1. Történelmi szupernóvák pozíciója, legvalószínúbb típusa és a maradványuk neve. . . . . . . . . . . . . . . . . . 6

2.1. A szintetikus magnitúdó meghatározásához használt összefüggésben (2.12. egyenlet) szereplő koefficiensek (Hamuy, 2001) . . . . . . . . . . . . . . . 26

2.2. Eastman és mtsai (1996) (E96) és Dessart \& Hillier (2005b) (D05) modellszámításai alapján kapott, a (2.16) egyenletben szereplő $a_{S, j}$ koefficiensek értékei különböző szűrőkombinációk esetén. . . . . . . . . . . . . . . . . 30

4.1. Az itt szereplő szupernóvák fizikai paramétereinek összefoglalása. . . . . . . 46

4.2. Az SN 1999em különböző módszerekkel kapott tágulási sebessége. . . . . . 48

4.3. Az SN 1999em és galaxisának, az NGC 1637-nek a különböző módszerekkel meghatározott távolsága. . . . . . . . . . . . . . . . . 52

4.4. Az SN 2004dj különböző módszerekkel kapott tágulási sebessége. . . . . . . . 53

4.5. Az SN 2004dj és galaxisának, az NGC 2403-nak a különböző módszerekkel meghatározott távolsága. . . . . . . . . . . . . . . . . 54

4.6. Az SN 2004et különböző módszerekkel kapott tágulási sebessége. . . . . . . . 57

4.7. Az SN 2004et és galaxisának, az NGC 6946-nak a különböző módszerekkel meghatározott távolsága. . . . . . . . . . . . . . . . 58

4.8. Az SN 2005cs különböző módszerekkel kapott tágulási sebessége. . . . . . . . 62

4.9. Az SCM kalibrációja során meghatározott, a (2.17) és (2.18) egyenletben szereplő Hamuy (2005) által meghatározott, illetve az általunk, SN 2005cs adatainak felhasználásával kapott értékei. Az utolsó oszlop az SN 2005cs ezen konstansok segítségével számolt távolságát mutatják. . . . . . . . . . . 66

4.10. Az M51 különböző módszerekkel kapott távolsága. . . . . . . . . . . . . . . 67

4.11. Az SN 2006bp különböző módszerekkel kapott tágulási sebessége. . . . . . 69

4.12. Az SN 2006bp és galaxisa, az NGC 3953 különbözô módszerekkel kapott távolsága. . . . . . . . . . . . . . . . . . . . 69

4.13. Az SN 2011dh különböző módszerekkel kapott tágulási sebessége. . . . . . . 74

5.1. Az (5.1) egyenlet illesztése során kapott $a_{j}$ koefficiensek mind $v_{\mathrm{H} \beta}$, mind $v_{\mathrm{Fe}}$ esetében. . . . . . . . . . . . . . . . . . 8 82

5.2. Az öt, II-P típusú szupernóva EPM-mel meghatározott távolsága a $v_{\text {modell }}$ valamint a $v_{\mathrm{Fe}}$ sebességek felhasználásával. 
5.3. A vizsgált II-P típusú szupernóvák távolsága $(D)$, a plató fázis időbeli hossza $\left(t_{p}\right)$, valamint a $V$ szúrôs abszolút magnitúdó $\left(M_{V, p}\right)$ és tágulási sebesség $\left(v_{p}\right)$ a plató közepén. Mindegyik SN esetében a felsố sor az általam kapott értékeket mutatja, míg az alsó sorban mások eredményei ${ }^{b}$ láthatók. . . . . . . 85

5.4. Az öt II-P típusú szupernóva néhány, az (5.4) és (5.6) összefüggések segítségével, az 5.3. táblázat adataiból számolt fizikai tulajdonsága. Hasonlóan, mint a 5.3. táblázatban, minden $\mathrm{SN}$ esetében a felső sor az újonnan, $v_{\text {modell }}$ sebesség felhasználásával kapott távolságokból számolt értékeket tartalmazza, míg az alsó sor a korábbi munkákban kapottakat mutatja. . . . . . . . . . 87

A.1. Az SN 1999em spektrumaira legjobban illeszkedő SYNOW modellek legfontosabb paraméterei. . . . . . . . . . . . . . . . . . . . . 108

A.2. Az SN 2004dj spektrumaira legjobban illeszkedó SYNOW modellek legfontosabb paraméterei. . . . . . . . . . . . . . . . . . . . . . . 109

A.3. Az SN 2004et spektrumaira legjobban illeszkedő sYNOW modellek legfontosabb paraméterei. . . . . . . . . . . . . . . . . . . . . 110

A.4. Az SN 2005cs spektrumaira legjobban illeszkedő SYNOW modellek legfontosabb paraméterei. . . . . . . . . . . . . . . . . . 111

A.5. Az SN 2006bp spektrumaira legjobban illeszkedő SYNOW modellek legfontosabb paraméterei. . . . . . . . . . . . . . . . . . . . 112

A.6. Az SN 2011dh spektrumaira legjobban illeszkedő SYNOW modellek legfontosabb paraméterei. . . . . . . . . . . . . . . . . . . 113 


\section{Ábrák jegyzéke}

1.1. Különbözô hullámhossztartományban készült képek az SN 185 (balra fent), SN 1054 (balra lent), SN 1064 (jobbra fent), SN 1572 (jobbra lent) és SN 1987A (középen) maradványáról. (Forrás: NASA/ESA) . . . . . . . . . . . . 6

1.2. Szupernóvák alapvetô csoportosítása a spektrumban található atomok/ionok és a fénygörbe alapján. . . . . . . . . . . . . . . . . . . . 7

1.3. Példák a különböző típusú SN-k spektrumára. Ia - SN 2011fe (Vinkó és mtsai, 2012b), Ic - SN 2007gr (Valenti és mtsai, 2008b), Ib - 2009jf (Valenti és mtsai, 2011), IIb - SN2011dh (Vinkó és mtsai, 2012a), II-P - SN 1999em (Leonard és mtsai, 2002), IIn - SN 2010jl (Zhang és mtsai, 2012). . . . . . .

1.4. A különböző alcsoportba tartozó megfigyelt SN-k gyakorisága (Li és mtsai cikkének 9. ábrája). A bal szélen lévő ábra azt mutatja, hogy a teljes mintából mennyi SN tartozik a három fó típus egyikébe. A másik három ábra a fô csoportok (Ia, Ib/c, II) altípusainak eloszlását mutatja. . . . . . . . . 10

1.5. A különböző SN-k B szúrôs fénygörbéjének vázlatos összehasonlítása (Forrás: Filippenko, 1997). . . . . . . . . . . . . . . . . . . 12

1.6. A nagy tömegú csillagok hagymahéjszerú belső szerkezete életük végén(Forrás: Carroll \& Ostlie, 1996) . . . . . . . . . . . . . . . . . . . . . . . . 14

1.7. A különböző típusú SN-k spektruma és a CC SN-k belsô szerkezete (Forrás: Modjaz, 2011) . . . . . . . . . . . . . . . . . . 16

1.8. Szupernóvák szülő́csillagainak archív HST-képek alapján megállapított tömege (Smartt, 2009). . . . . . . . . . . . . . . . . . . . 17

1.9. A II-P típusú szupernóvák abszolút fényessége meglehetôsen nagy szórást mutat. Az ábrán több ilyen típusú SN luminozitásának időbeli lefutása látható. (Forrás: Pastorello és mtsai, 2009) . . . . . . . . . . . . . . . . . 18

1.10. A II-P (piros), II-L (szürke) és IIb (zöld) típusú SN-k fénygörbéi (Arcavi és mtsai, 2012), melyek jól elkülöníthető csoportokba rendeződnek. . . . . . . . 19

2.1. Mind Riess és mtsai (jobbra), mind Perlmutter és mtsai eredményei (balra) arra utalnak, hogy az Univerzum gyorsulva tágul ${ }^{8} \ldots$. . . . . . . . . . . . 21

2.2. A P Cygni vonalprofil létrejöttének vázlatos szemléltetése . . . . . . . . . . . 27

2.3. A II-P SN-kra korai fázisban (bal felsô kép) és a plató közepére (jobb felsô kép) jellemzô modellspektrum. Az alsó ábrákon a kapott CCF látható, melyeken a szaggatott vonal a keresztkorreláltatott két spektrum közti valódi, $\Delta v_{\text {fot }}$ sebességkülönbség helyét jelöli, míg a nyíl a CCF maximumának helyét mutatja (Takáts \& Vinkó, 2012). . . . . . . . . . . . . . . . . 28 
2.4. A Eastman és mtsai (1996) (fekete) és a Dessart \& Hillier (2005b) (piros) által számolt $\zeta$ korrekciós faktorok összehasonlítása különböző szúrőkombinációk esetén.

2.5. Példa arra, hogy a hőmérséklet meghatározását befolyásolja az, hogy mely szűrőkombinációt használjuk. Az SN 1999em robbanás után 24 nappal észlelt spektrumának (fekete) elkészítettem a modelljét a SYNOW-val (piros, $T_{\text {SYNOW }}$. Az ugyanezen a napon készült $B V R I$ fotometriai mérések segítségével (kék pöttyök) meghatároztam a hőmérsékletet különböző szúrőkombinációk esetén $\left(T_{B V R I}, T_{B V}\right.$ és $\left.T_{V I}\right) \ldots \ldots \ldots \ldots \ldots$

2.6. A plató közepén mérhető fényesség és tágulási sebesség közti kapcsolat. Látható, hogy a halványabb SN-ket csak az SN 1999br és 2005cs képviseli (Takáts \& Vinkó, 2006).

3.1. A Sobolev-közelítésben történő vonalprofilszámítást szemléltető ábra.

3.2. Az SN 1999em észlelt (fekete) és modellezett spektruma (piros) a robbanás után 9 (fent) és 41 nappal (alul). A jobb oldalon kinagyítva látható azoknak a vonalaknak a tartománya (H $\beta$, fent, Fe II $5169 \AA$, lent), amelyek segítségével meghatároztam a sebességet.

3.3. A $v_{\text {modell }}$ többi paramétertől való függésének vizsgálata a $\chi^{2}$ minimuma körüli kontúrok segítségével. A $v_{\text {modell }}$ értéke egyértelmú korrelációt mutat az optikai mélység változását leíró hatványfüggvény $n$ kitevőjével (bal fenti kép) valamint az Fe II referenciavonalának $\tau_{\text {ref }}$ optikai mélységével (jobb fent). Nem figyelhetô meg viszont egyértelmú korreláció a Ti II (balra lent)

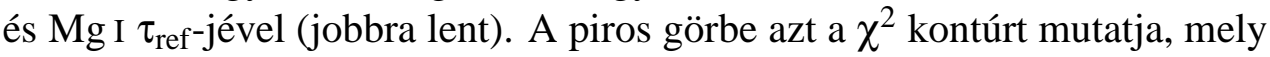
$50 \%$-kal nagyobb a minimum értékénél. . . . . . . . . . . . . . 43

4.1. Az SN 1999em sebességének különböző módszerekkel mért értékei. . . . . . 49

4.2. Az SN 1999em spektrumai és a rájuk illesztett modellek. . . . . . . . . . . . 50

4.3. Az SN 1999em spektrumai és a rájuk illesztett modellek - folytatás. . . . . . 51

4.4. Az SN 2004dj sebességének különböző módszerekkel mért értékei. . . . . . . . 54

4.5. Az SN 2004dj spektrumai és a rájuk illesztett modellek. . . . . . . . . . . . . 55

4.6. Az SN 2004et sebességének különböző módszerekkel mért értékei. . . . . . . 58

4.7. Az SN 2004et spektrumai és a rájuk illesztett modellek. . . . . . . . . . . . . 59

4.8. Az SN 2004et spektrumai és a rájuk illesztett modellek - folytatás. . . . . . . 60

4.9. Az SN 2005cs spektrumai és a rájuk illesztett modellek. . . . . . . . . . . . . 64

4.10. Az SN 2005cs spektrumai és a rájuk illesztett modellek - folytatás. . . . . . . 65

4.11. Az SN 2005cs sebességének különböző módszerekkel mért értékei. . . . . . 66

4.12. Az SN 2006bp spektrumai és a rájuk illesztett modellek. . . . . . . . . . . . 70

4.13. Az SN 2006bp sebességének különböző módszerekkel mért értékei. . . . . . . 71

4.14. Az SN 2006bp észlelt spektruma (fekete) a robbanás utáni 32. napon, együtt a CMFGEN-el (piros) valamint a SYNOW-val (türkiz) készült modellspektrumokkal. A jobb felső sarokban a 4500 és 5500 Å közötti hullámhossztartomány látható kinagyítva. . . . . . . . . . . . . . . . . . 71

4.15. Az SN 2011dh spektrumai és a rájuk illesztett modellek. . . . . . . . . . . . 74

4.16. Az SN 2011dh különböző módszerekkel meghatározott tágulási sebessége. 75 
5.1. A SYNOW modellezés során kapott $v_{\text {modell }}$ sebességek összehasonlítása a különböző szupernóvák esetében (balra fent). A $v_{\text {modell }} / v_{\text {nlte }}$ arány (jobbra fent), a $v_{\mathrm{Fe}} / v_{\text {modell }}$ (balra lent) és a $v_{\mathrm{H} \beta} / v_{\text {modell }}$ (jobbra lent) arány a fázis függvényében. Az egyes szupernóvákat más-más szimbólumok jelölik: zöld, teli pötty - SN 1999em; kék, üres háromszög - SN 2004dj; piros, csillag SN 2004et; rózsaszín, teli háromszög - SN 2005cs; fekete, üres kör - SN 2006bp. . . . . . . . . . . . . . . . . . 78

5.2. A $v_{\text {modell }}$ és $v_{\mathrm{abs}}$ valamint a $v_{\mathrm{cc}}$ sebességek aránya a robbanás utáni eltelt idő függvényében. A különböző szimbólumok a különböző szupernóvákat jelölik az 5.1. ábrán feltüntetett módon.

5.3. A $v_{\mathrm{Fe}} / v_{\text {modell }}$ (balra) és a $v_{\mathrm{H} \beta} / v_{\text {modell }}$ (jobbra) arány a $v_{\text {modell }}$ sebesség függvényében. Az egyes szimbólumok a különbözô szupernóvákat jelentik, az 5.1. ábránál leírt módon. . . . . . . . . . . . . . . . . . . .

5.4. Fent: $v_{\text {modell }}$ sebesség $v_{\mathrm{H} \beta}$ függvényében. A görbék mutatják a Jones és mtsai (2009) által egyrészt Eastman és mtsai (piros pontozott vonal), másrészt Dessart \& Hillier (kék szaggatott vonal) modelljei alapján meghatározott polinomokat. Feltüntettem azokat a görbéket is, melyeket a Takáts \& Vinkó (2012) cikkben meghatározott sebességekre történt illesztéssel kaptam, egyrészt mind az öt SN felhasználásával (fekete pontozott vonal), másrészt a SN 2004et kihagyásával (fekete folytonos vonal). Lent: az illesztés a $v_{\mathrm{Fe}}$ sebességek esetében is elvégeztem, mind az öt SN adataira. Mindkét ábra esetében a szimbólumok a különbözô szupernóvákat jelentik, az 5.1. ábrán leírt módon. Az illesztett polinomok koefficiensei az 5.1. táblázatban

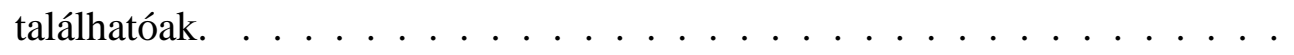

5.5. A $v_{\mathrm{Fe}}$ és $v_{\mathrm{H} \beta}$ sebességek között fennálló összefüggés. Az üres körök a 40. napnál későbbi adatokat jelentik, míg a teli körök az ennél korábbiakat. Az egyenes illesztését a 40. napnál korábbi adatokra végeztem. . . . . . . . . . .

.6. A $v_{\mathrm{Fe}}$ és $v_{\text {modell }}$ sebességek időbeli lefutása. A bal oldali ábrán a szaggatott vonal a Nugent és mtsai (2006) által meghatározott görbét mutatja, míg a folytonos görbét az általam vizsgált öt $\mathrm{SN}$ adataira végzett illesztés során kaptam (Takáts \& Vinkó, 2012). Mind a két féle sebesség esetén az SN 2005cs adatait (rózsaszín háromszögek) kihagytam az illesztésből. Az egyes szimbólumok a különbözô szupernóvákat jelentik az 5.1. ábránál leírtak sze-

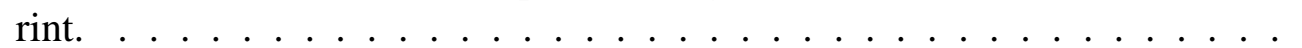

5.7. A dolgozatban szereplő öt szupernóva (piros) és a Vinkó \& Takáts (2007) mintájában szereplő SN-k (kék) EPM-mel kapott távolságának összehasonlítása a galaxisuk vöröseltolódásából meghatározott távolsággal, együtt néhány közeli Ia adatával (szürke). Az alsó ábra a két távolság különbségét mutatja. . . . . . . . . . . . . . . . . 


\section{Irodalomjegyzék}

[1] Arcavi, I. et al., 2011, ApJL 742, 18

[2] Arcavi, I. et al., 2012, ApJL 756, 30

[3] Arnett, W. D., 1980, ApJ 237, 541

[4] Baade, W., 1938, ApJ 88, 285

[5] Baade, W. \& Zwicky, F. 1934, PNAS 20, 254

[6] Baron, E. et al., 1995, ApJ 441, 170

[7] Baron, E. et al., 1996, MNRAS 279, 799

[8] Baron, E. et al., 2004, ApJL 616, 91

[9] Baron, E. et al, 2007, ApJ 662, 1148

[10] Barone-Nugent, R. L. et al., 2012, MNRAS 425, 1007

[11] Benvenuto, O. G. et al., 2013, ApJ 762, 74

[12] Bersten, M. C. \& Hamuy, M., 2009, ApJ 701, 200

[13] Bersten, M. C. et al., 2012, ApJ 757, 31

[14] Blondin, S. \& Tonry, J. L., 2007, ApJ 666, 1024

[15] Branch, D., Baron, E. A., Jeffery, D. J., 2003, in Supernovae and Gamma-Ray Bursters. Ed. by K. Weiler., Lecture Notes in Physics, vol. 598, p. 47.

[16] Carroll, B. W. \& Ostlie, D. A., 1996, An Introduction to Modern Astrophysics, Addison-Wesley

[17] Chatzopoulos, E. et al., 2012, ApJ 746, 121

[18] Chugai, N. N. et al., 2005, AstL 31, 792

[19] Ciardullo, R. et al., 2002, ApJ 577, 31

[20] Crockett, R. M. et al., 2011, MNRAS 410, 2767 
[21] Davis, T. M. et al., 2007, ApJ 666, 716

[22] Dessart, L. \& Hillier, D. J., 2005a, A\&A 437, 667

[23] Dessart, L. \& Hillier, D. J., 2005b, A\&A 439, 671

[24] Dessart, L. \& Hillier, D. J., 2006, A\&A 447, 691

[25] Dessart, L. et al., 2008, ApJ 675, 644

[26] Dopita, M. A., 1988, SSRv 46, 225

[27] Eastman, R. G. et al., 1996, ApJ 466, 911

[28] Eldridge, J. J. et al., 2007, MNRAS 376, L52

[29] Elmhamdi, A. et al., 2003, MNRAS 338, 939

[30] Filippenko, A. V., 1997, ARA\&A 35, 309

[31] Filippenko, A. V. et al., 1993, ApJL 415, 103

[32] Fisher, A., 1999, PhD thesis, University of Oklahoma

[33] Folatelli G. et al., 2010, ApJ, 139, 120

[34] Freedman, W. L. et al., 2001, ApJ 553, 47

[35] Fraser, M. et al., 2011, MNRAS 417, 1417

[36] Fraser, M. et al., 2012, ApJL 759, 13

[37] Galama, T. J. et al., 1998, Nature 395, 670

[38] Gal-Yam, A., 2012, Science 337, 927

[39] Georgiev, Ts. V. et al. 1990, P. Astron. Zh. 16, 979

[40] Green, D. A. \& Stephenson, F. R. 2003, Supernovae and Gamma-Ray Bursters. Edited by K. Weiler., Lecture Notes in Physics, vol. 598, p.7.

[41] Griga, T. et al., 2011, Central Bureau Electronic Telegrams, 2736, 1

[42] Guy J. et al., 2007, A\&A 466, 11

[43] Hamuy, M., 2001, PhD-thesis, Univ. of Arizona

[44] Hamuy, M. et al., 2001, ApJ 558, 615

[45] Hamuy, M. \& Pinto, P. A. 2002, ApJL 566, 63

[46] Hamuy, M. 2003, ApJ, 582, 905 
[47] Hamuy, M., 2005, in Marciade J. M., Weiler K. W., eds, Proc. IAU Coll. 194, Cosmic Explosions. On the 100th Anniversary of SN 1993J. Springer-Verlag, Berlin, p. 535

[48] Hatano, K. et al., 1999, ApJS 121, 233

[49] Hauschildt, P. H. \& Baron, E. 1999, JCoAM 109, 41

[50] Herrmann, K. A. et al., 2008, ApJ 683, 630

[51] Hjorth, J. et al., 2003, Nature 423, 847

[52] Hoyle, F. \& Fowler, W. A., 1960, ApJ, 132, 565

[53] Iben, Jr., I., \& Tutukov, A. V. 1984, ApJS, 54, 335

[54] Immler, S. et al., 2007, ApJ 664, 435

[55] Iwamoto, K. et al., 1994, ApJ 437, 115

[56] Iwamoto, K. et al., 2000, ApJ 534, 660

[57] Jha, S. et al., 2007, ApJ 659, 122

[58] Jones, M. I. et al., 2009, ApJ 696, 1176

[59] Kasen, D. et al., 2002, ApJ 565, 380

[60] Kattner S. et al., 2012, PASP 124, 127

[61] Kessler, R. et al., 2009, ApJS, 185, 32

[62] Kirshner, R. P. \& Kwan, J. 1974, ApJ 193, 27

[63] Kloehr, W. et al., 2005, IAU Circ. 8553, 1

[64] Kotak, R. et al., 2005, ApJ 628, L123

[65] Krause, O. et al. 2008a, Science 320, 1195

[66] Krause, O. et al. 2008b, Nature 456, 617

[67] Krisciunas K. et al., 2004, ApJL 602, 81

[68] Leonard, D. C., et al., 2001, ApJ 553, 861

[69] Leonard, D. C. et al., 2002, PASP 114, 35

[70] Leonard, D. C. et al., 2003, ApJ 594, 247

[71] Leonard, D. C. et al., 2006, Nature 440, 505

[72] Li W. D., 1999, IAU Circ., 7294, 1

[73] Li, W. et al., 2005, PASP, 117, 121 
[74] Li, W. et al., 2006, ApJ 641, 1060

[75] Li, W. et al., 2011a, MNRAS 412, 1441

[76] Li, W. et al., 2011b, Nature 480, 348

[77] Litvinova, I. Y. \& Nadezhin, D. K., 1983, Ap\&SS 89, 89

[78] Litvinova, I. Y. \& Nadezhin, D. K., 1985, SvAL 11, 145

[79] Maeda, K., 2012, ApJ 758, 81

[80] Maguire, K. et al., 2010a, MNRAS 403, L11

[81] Maguire, K. et al., 2010b, MNRAS 404, 981

[82] Maíz-Apellániz, J. et al., 2004, ApJ 615, L113

[83] Malesani, D. et al., 2004, ApJ 609, 5

[84] Maund, J. R. et al., 2005, MNRAS 364, L33

[85] Maund, J. R. et al., 2011, ApJL 739, 37

[86] Mazzali, P. A. et al., 2002, ApJL 572, 61

[87] Mazzali, P. A. et al., 2006, Nature 442, 1018

[88] Mazzali, P. A. et al., 2007, in Supernova 1987A: 20 Years After: Supernovae and Gamma-Ray Bursters, AIP Conference Proceedings, Volume 937, p. 443

[89] Meikle W. P. S., 2000, MNRAS, 314, 782

[90] Meikle, W. P. S. et al., 2011, ApJ 732, 109

[91] Misra, K. et al., 2007, MNRAS 381, 280

[92] Mitchell, R. C. et al., 2002, ApJ 574, 293

[93] Modjaz, M., 2011, AN 332, 434

[94] Munari, U. \& Zwitter, T. 1997 A\&A 318, 269

[95] Murphy, J. W. et al., 2011 ApJL 742, 4

[96] Nadyozhin, D. K., 2003, MNRAS 346, 97

[97] Nakano S. \& Itagaki K., 2006, IAU Circ. 8700, 4

[98] Nakano, S. et al., 2004, IAU Circ. 8377, 1

[99] Nomoto, K. I. et al., 1995, PhR 256, 173 
[100] Nomoto, K. I. et al., 2007, in Supernova 1987A: 20 Years After: Supernovae and Gamma-Ray Bursters, AIP Conference Proceedings, Volume 937, p. 412

[101] Nugent, P. et al., 2006, ApJ 645, 841

[102] Nugent, P. et al., 2011, Nature 480, 344

[103] Olivares E. F. et al., 2010 ApJ 715, 833

[104] Pastorello, A. et al., 2006, MNRAS 370, 1752

[105] Pastorello, A. et al., 2009, MNRAS 394, 2266

[106] Pastorello, A. et al., 2012, A\&A 537, 141

[107] Perlmutter, S. et al., 1999, ApJ 517, 565

[108] Phillips, M. M., 1993, ApJL 413, 105

[109] Poznanski, D. et al., 2009, ApJ 694, 1067

[110] Poznanski, D. et al., 2010, ApJ 721, 956

[111] Poznanski, D. et al., 2011 MNRAS 415, L81

[112] Poznanski, D. et al., 2012, MNRAS 426, 1465

[113] Quimby R. M. et al., 2006, CBET 471, 1

[114] Quimby, R. M. et al., 2007, ApJ 666, 1093

[115] Riess, A. G. et al, 1996, ApJ, 473, 88

[116] Riess, A. G. et al., 1998, AJ 116, 1009

[117] Riess, A. G. et al., 2005, ApJ 627, 579

[118] Riess, A. G. et al., 2007, ApJ 659, 98

[119] Roy, R. et al., 2011, ApJ 736, 76

[120] Russell, D. G., 2002, ApJ 565, 681

[121] Sahu, D. K. et al., 2006, MNRAS 372, 1315

[122] Schlafly, E. F. \& Finkbeiner, D. P., 2011, ApJ 737, 103

[123] Schlegel, E. M. 1990, MNRAS 244, 269

[124] Schmidt, B. P. et al., 1994a, AJ 107, 1444

[125] Schmidt, B. P. et al., 1994b, ApJ 432, 42

[126] Smartt, S. J. et al., 2002, ApJ 565, 1089 
[127] Smartt, S. J., 2009, ARA\&A 47, 63

[128] Smartt, S. J. et al. 2009, MNRAS 395, 1409

[129] Soderberg, A. M. et al., 2012, ApJ 752, 78

[130] Springob, C. M. et al., 2009 ApJS 182, 474

[131] Starling, R. L. C. et al., 2011, MNRAS 411, 2792

[132] Szalai, T. et al., 2011, A\&A 527, 61

[133] Szalai, T., 2011, Fizikai Szemle 2011/11. 377. o.

[134] Takáts, K. \& Vinkó, J., 2006, MNRAS 372, 1735

[135] Takáts, K. \& Vinkó, J., 2012, MNRAS, 419, 2783

[136] Thomas, R. C. et al., 2011, PASP 123, 237

[137] Tonry, J. L. et al., 2001, ApJ 546, 681

[138] Tully, R. B. \& Fisher, J. R., 1977, A\&A 54, 661

[139] Tully, R. B. 1988, Nearby Galaxy Catalog

[140] Turatto, M. et al., 1998, ApJL 498, 129

[141] Turatto, M., Benetti, S. \& Cappellaro, E., 2003, in From Twilight to Highlight: The Physics of Supernovae, ed. W. Hillebrandt \& B. Leibundgut, p200, Springer Berlin, Heidelberg

[142] Tsvetkov, D. Yu. et al., 2006, A\&A 460, 769

[143] Tsvetkov, D. Yu. et al., 2008, PZ 28, 8

[144] Tsvetkov, D. Yu. et al., 2012, PZ 32, 6

[145] Utrobin, V. P., 1993, A\&A 270, 249

[146] Utrobin, V. P., 2005, AstL 31, 806

[147] Utrobin, V. P., 2007, A\&A 461, 233

[148] Utrobin, V. P. \& Chugai, N. N., 2008, A\&A 491, 507

[149] Utrobin, V. P. \& Chugai, N. N., 2009, A\&A 506, 829

[150] Valenti, S. et al., 2008a, MNRAS 383, 1485

[151] Valenti, S. et al., 2008b, ApJL 673, 155

[152] Valenti, S. et al., 2011, MNRAS 416, 3138 
[153] Van Dyk, S. D. et al., 2011, ApJL 741, 28

[154] Van Dyk, S. D. et al., 2012, ApJ 756, 131

[155] Vinkó, J. et al., 2006, MNRAS, 369, 1780

[156] Vinkó, J., Takáts, K., 2007, in Supernova 1987A: 20 Years After: Supernovae and Gamma Ray Bursters, AIP Conference Proceedings, Volume 937, p. 394

[157] Vinkó, J. et al., 2009, ApJ, 695, 619

[158] Vinkó, J. et al., 2012a, A\&A 540, 93

[159] Vinkó, J. et al., 2012b, A\&A 546, 12

[160] Wang, X. et al., 2005, ApJ 626, L89

[161] Wang, L. \& Wheeler, J. C., 2008, ARA\&A 46, 433

[162] Webbink, R. F., 1984, ApJ, 277, 355

[163] Whelan, J., \& Iben, I., 1973, ApJ, 186, 1007

[164] Willick, J. A. et al., 1997, ApJS 109, 333

[165] Wood-Vasey, W. M. et al., 2007, ApJ 666, 694

[166] Woosley, S. E., 1988, ApJ 330, 218

[167] Yamaoka, H. et al., 2004, IAU Circ. 8413, 2

[168] Zhang, T. et al., 2006, AJ 131, 2245

[169] Zhang, T. et al., 2012, AJ 144, 131

[170] Zwitter, T. et al., 2004, IAU Circ. 8413, 1 


\section{A. Melléklet}

\section{A S YNOW modellek legfontosabb paraméterei}

Az alábbi táblázatokban a szupernóva-spektrumok modellezése során meghatározott legfontosabb paraméterek értékeit foglalom össze. Megtalálhatóak a modellezés során felhasznált atomok és ionok referenciavonalának optikai mélysége $\left(\tau_{r e f}\right)$, annak a hatványfüggvénynek a kitevője, mely leírja az optikai mélység változását az atmoszférában a sugár függvényében $(n)$, a feketetest-sugárzás hőmérséklete $\left(T_{b b}\right)$, valamint a megállapított fotoszferikus sebesség ( $\left.v_{\text {modell }}\right)$. 
A.1. táblázat. Az SN 1999em spektrumaira legjobban illeszkedő SYNOW modellek legfontosabb paraméterei.

\begin{tabular}{|c|c|c|c|c|c|c|c|c|c|c|c|c|c|c|}
\hline & \multicolumn{14}{|c|}{ SN 1999em } \\
\hline & \multirow{2}{*}{$\begin{array}{c}\mathrm{JD}-2.451 .000 \\
\text { (nap) }\end{array}$} & \multicolumn{10}{|c|}{$\tau_{\text {ref }}$} & \multirow[t]{2}{*}{$\mathrm{n}$} & \multirow{2}{*}{$\begin{array}{c}T_{\mathrm{bb}} \\
(\mathrm{kK})\end{array}$} & \multirow{2}{*}{$\begin{array}{r}v_{\text {modell }} \\
\left(\mathrm{kms}^{-1}\right)\end{array}$} \\
\hline & & $\mathrm{HI}$ & $\mathrm{He} \mathrm{I}$ & $\mathrm{Na} \mathrm{I}$ & Si I & Si II & Ca II & Sc II & Ti II & Fe II & Ba II & & & \\
\hline $4,79^{\mathrm{a}}$ & 481,79 & 2,80 & 0,25 & & & & & & & & & 3,0 & 14,2 & 11050 \\
\hline $5,84^{b}$ & 482,84 & 3,50 & 0,20 & & & & & & & & & 3,0 & 12,0 & 10900 \\
\hline $6,84^{b}$ & 483,84 & 4,90 & 0,40 & & & & & & & & & 3,0 & 11,0 & 9950 \\
\hline $7,64^{\mathrm{a}}$ & 484,64 & 6,30 & 0,35 & & & & & & & & & 3,0 & 9,5 & 8900 \\
\hline $8,67^{\mathrm{a}}$ & 485,67 & 7,30 & 0,20 & & & & & & & & & 3,5 & 13,6 & 8850 \\
\hline $12,84^{\mathrm{b}}$ & 489,84 & 15,80 & 0,10 & & & & & & & & & 5,5 & 10,0 & 8550 \\
\hline $14,14^{b}$ & 491,14 & 21,10 & & 0,20 & & & & & & 0,30 & & 5,0 & 11,0 & 7350 \\
\hline $14,67^{\mathrm{a}}$ & 491,67 & 26,15 & 0,05 & 0,10 & & & 2,20 & & & 0,80 & 0,35 & 6,5 & 11,5 & 8150 \\
\hline $15,14^{\mathrm{a}}$ & 492,14 & 20,20 & & 0,10 & & 0,25 & & & & 0,70 & & 4,5 & 10,4 & 7650 \\
\hline $19,67^{\mathrm{a}}$ & 496,67 & 42,05 & & 0,10 & & & 16,0 & 0,05 & 0,30 & 0,95 & 0,40 & 5,0 & 9,0 & 6750 \\
\hline $24,66^{\mathrm{a}}$ & 501,66 & 113,50 & & 0,55 & & & 131,9 & 0,25 & 2,10 & 1,85 & & 8,0 & 8,3 & 6150 \\
\hline $24,84^{b}$ & 501,84 & 81,00 & & 0,35 & & & 17,6 & 0,15 & 1,10 & 1,60 & 0,40 & 7,0 & 8,3 & 6150 \\
\hline $27,84^{\mathrm{b}}$ & 504,84 & 73,95 & & 0,40 & & & & 0,30 & 1,80 & 2,25 & 0,20 & 6,0 & 8,2 & 5000 \\
\hline $29,84^{b}$ & 506,84 & 65,00 & & 0,45 & & & & 0,15 & 1,65 & 4,10 & & 6,0 & 7,0 & 4650 \\
\hline $33,84^{b}$ & 510,84 & 42,20 & & 1,10 & 0,01 & & 95,0 & 0,05 & 1,20 & 2,20 & & 4,5 & 5,2 & 4300 \\
\hline $37,84^{\mathrm{b}}$ & 514,84 & 39,60 & & 1,00 & 0,01 & 0,10 & & 0,15 & 1,55 & 2,25 & & 4,5 & 5,5 & 3900 \\
\hline $41,04^{b}$ & 518,04 & 57,20 & 0,20 & 1,70 & 0,01 & 0,35 & 458,0 & 0,20 & 4,05 & 4,25 & 0,20 & 7,0 & 6,8 & 3600 \\
\hline $47,84^{\mathrm{b}}$ & 524,84 & 23,00 & & 1,85 & 0,01 & 0,35 & 200,0 & 0,45 & 2,30 & 2,20 & 1,00 & 3,0 & 4,5 & 3200 \\
\hline $50,74^{\mathrm{a}}$ & 527,74 & 30,80 & & 2,05 & 0,01 & 0,35 & 90,0 & 0,65 & 3,75 & 3,35 & & 4,5 & 5,3 & 3400 \\
\hline $51,76^{\mathrm{a}}$ & 528,76 & 36,60 & & 1,95 & 0,02 & & 212,0 & 0,20 & 0,50 & 2,65 & 0,25 & 3,0 & 6,5 & 2800 \\
\hline $66,76^{\mathrm{a}}$ & 543,76 & 16,80 & & 5,65 & 0,03 & 0,40 & & 1,25 & 7,45 & 6,45 & & 3,5 & 5,5 & 2300 \\
\hline $79,84^{\mathrm{b}}$ & 556,84 & 71,50 & & 13,95 & 0,02 & 0,65 & 969,0 & 2,35 & 17,95 & 13,90 & 4,70 & 3,5 & 6,0 & 1800 \\
\hline
\end{tabular}

A spektrumok forrása:

${ }^{a}$ Leonard és mtsai (2002)

${ }^{b}$ Hamuy és mtsai (2001) 
A.2. táblázat. Az SN 2004dj spektrumaira legjobban illeszkedô SYNOW modellek legfontosabb paraméterei.

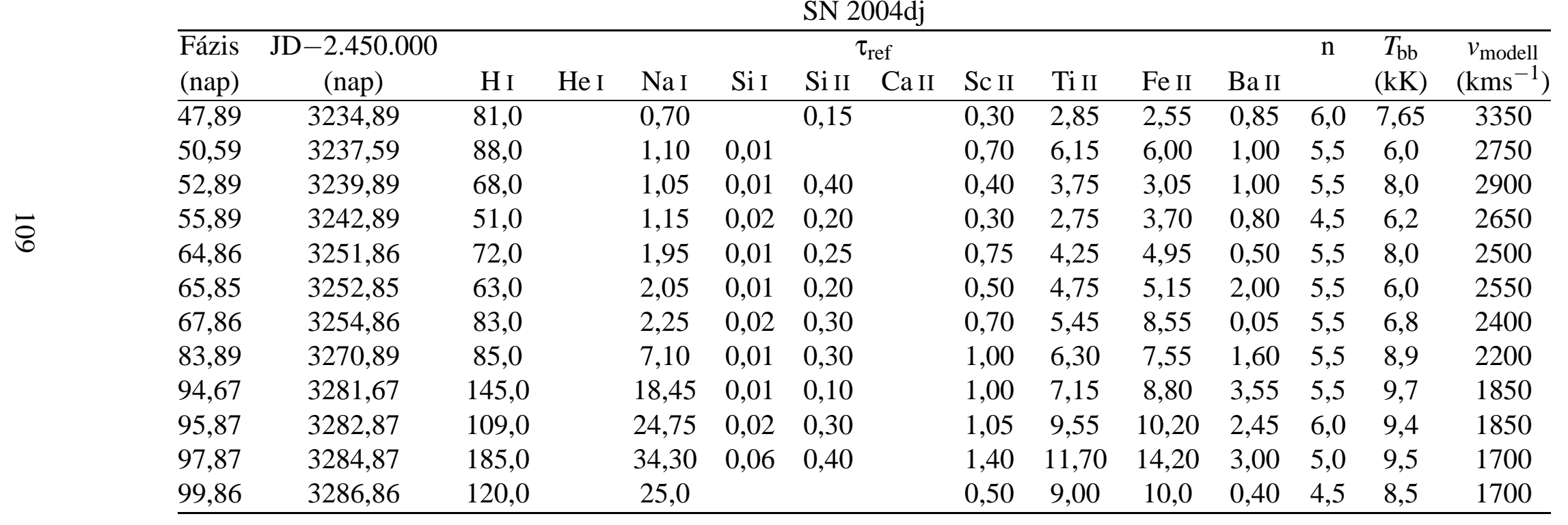


A.3. táblázat. Az SN 2004et spektrumaira legjobban illeszkedő SYNOW modellek legfontosabb paraméterei.

\begin{tabular}{|c|c|c|c|c|c|c|c|c|c|c|c|c|c|c|}
\hline & \multicolumn{14}{|c|}{ SN 2004et } \\
\hline & \multirow{2}{*}{$\begin{array}{c}\mathrm{JD}-2.451 .000 \\
\text { (nap) }\end{array}$} & \multicolumn{10}{|c|}{$\tau_{\text {ref }}$} & \multirow[t]{2}{*}{$\mathrm{n}$} & \multirow{2}{*}{$\begin{array}{c}T_{\mathrm{bb}} \\
(\mathrm{kK})\end{array}$} & \multirow{2}{*}{$\begin{array}{r}v_{\text {modell }} \\
\left(\mathrm{kms}^{-1}\right)\end{array}$} \\
\hline & & H I & $\mathrm{He} \mathrm{I}$ & $\mathrm{Na} \mathrm{I}$ & Si I & Si II & Ca II & Sc II & Ti II & $\mathrm{Fe}$ II & Ba II & & & \\
\hline $11,10^{\mathrm{a}}$ & 281,60 & 3,75 & 0,20 & & & & & & & & & 4,5 & 80,0 & 9700 \\
\hline $12,30^{\mathrm{a}}$ & 282,80 & 4,05 & 0,20 & & & & & & & & & 3,0 & 19,0 & 8900 \\
\hline $13,00^{\mathrm{a}}$ & 283,50 & 6,40 & 0,20 & & & & & & & & & 5,0 & 52,0 & 9100 \\
\hline $14,40^{\mathrm{a}}$ & 284,90 & 8,00 & & 0,30 & & & & & & & & 4,0 & 9,5 & 9200 \\
\hline $15,00^{\mathrm{a}}$ & 285,50 & 7,25 & 0,15 & & & & & & & & & 5,0 & 43,0 & 8800 \\
\hline $16,40^{\mathrm{a}}$ & 286,90 & 14,45 & 0,25 & & & & & & & & & 4,0 & 9,0 & 8400 \\
\hline $24,60^{\mathrm{b}}$ & 295,10 & 10,0 & & 0,10 & & & 4,00 & & & 0,85 & 0,20 & 3,0 & 11,0 & 7300 \\
\hline $30,60^{\mathrm{b}}$ & 301,10 & 21,0 & & 0,10 & & 0,40 & 74,4 & & 0,15 & 1,20 & & 4,5 & 7,9 & 6050 \\
\hline $35,50^{\mathrm{b}}$ & 306,00 & 41,0 & 0,10 & 0,05 & & & 97,0 & & 0,85 & 2,15 & 0,05 & 5,5 & 7,4 & 5500 \\
\hline $38,60^{b}$ & 309,10 & 47,0 & & 0,25 & 0,01 & & 98,0 & 0,15 & 1,45 & 2,80 & 0,05 & 4,0 & 7,2 & 5100 \\
\hline $40,70^{b}$ & 311,20 & 36,0 & & 0,15 & & 0,05 & 95,8 & 0,25 & 0,75 & 2,05 & 0,30 & 3,5 & 6,8 & 4600 \\
\hline $50,50^{\mathrm{b}}$ & 321,00 & 40,0 & & 0,65 & & & 324,0 & 0,25 & 1,25 & 2,35 & 0,70 & 3,0 & 5,4 & 3750 \\
\hline $54,00^{c}$ & 324,50 & 81,7 & & 0,90 & 0,01 & 0,75 & 32,7 & 0,55 & 4,60 & 3,55 & & 6,0 & 7,6 & 4050 \\
\hline $55,60^{\mathrm{b}}$ & 326,10 & 45,0 & & 0,95 & 0,01 & & 45,0 & 0,45 & 3,05 & 5,05 & 0,45 & 3,5 & 6,8 & 3600 \\
\hline $55,76^{\mathrm{c}}$ & 326,26 & 58,8 & & 1,20 & 0,02 & & 25,0 & 0,20 & 2,90 & 2,50 & & 4,0 & 7,3 & 3900 \\
\hline $63,50^{\mathrm{b}}$ & 334,00 & 31,0 & & 1,15 & & & 81,0 & 0,25 & 2,0 & 3,60 & & 2,5 & 5,0 & 3200 \\
\hline $73,60^{\mathrm{b}}$ & 344,10 & 79,0 & & 2,30 & & & 100,0 & 0,60 & 2,75 & 5,05 & 1,10 & 3,0 & 4,8 & 2600 \\
\hline $79,73^{c}$ & 350,23 & 79,9 & & 4,90 & & & 30,0 & 1,20 & 11,9 & 6,80 & & 4,5 & 7,1 & 2600 \\
\hline $84,79^{c}$ & 355,29 & 142,0 & & 7,35 & 0,01 & 0,50 & 10,0 & 0,65 & 9,15 & 5,45 & & 3,5 & 6,2 & 2400 \\
\hline $86,50^{\mathrm{b}}$ & 357,00 & 223,0 & & 3,15 & & 0,10 & 515,0 & 0,70 & 7,90 & 13,1 & & 4,0 & 5,2 & 2250 \\
\hline $98,60^{\mathrm{b}}$ & 369,10 & 72,25 & & 6,05 & & & 50,0 & 0,80 & 3,10 & 4,70 & 1,10 & 2,5 & 4,5 & 1900 \\
\hline $103,70^{c}$ & 374,20 & 219,0 & & 32,05 & & & 80,0 & 2,35 & 37,7 & 25,3 & 5,50 & 4,5 & 5,5 & 1800 \\
\hline
\end{tabular}

A spektrumok forrása:

${ }^{a}$ Takáts \& Vinkó (2012)

${ }^{b}$ Sahu és mtsai (2006)

${ }^{c}$ Maguire és mtsai (2010b) 
A.4. táblázat. Az SN 2005cs spektrumaira legjobban illeszkedő sYNOW modellek legfontosabb paraméterei.

\begin{tabular}{|c|c|c|c|c|c|c|c|c|c|c|c|c|c|c|c|c|}
\hline \multicolumn{17}{|c|}{ SN 2005cs } \\
\hline Fázis & JD-2.453.000 & & & & & & & ref & & & & & & $\mathrm{n}$ & $T_{\mathrm{bb}}$ & $v_{\text {modell }}$ \\
\hline (nap) & (nap) & H I & $\mathrm{He} \mathrm{I}$ & $\mathrm{N}$ II & $\mathrm{Na} \mathrm{I}$ & $M g$ I & Si I & Si II & Ca II & Sc II & Ti II & $\mathrm{Fe}$ II & Ba II & & $(\mathrm{kK})$ & $\left(\mathrm{km} \mathrm{s}^{-1}\right)$ \\
\hline 3,44 & 552,44 & 3,90 & 0,30 & 0,10 & & & & & & & & & & 4,0 & 15,0 & 7100 \\
\hline 4,41 & 553,41 & 7,00 & 0,40 & 0,10 & & & & 0,10 & & & & & & 4,5 & 15,0 & 6900 \\
\hline 5,39 & 554,39 & 10,6 & 0,30 & 0,10 & & & & & & & & & & 5,5 & 13,6 & 6500 \\
\hline 8,43 & 557,43 & 15,3 & 0,20 & & & & & 0,50 & & & & & 0,35 & 5,0 & 10,6 & 5900 \\
\hline 8,84 & 557,84 & 9,00 & 0,30 & & & & & 0,60 & & & & & 0,45 & 9,5 & 9,8 & 5950 \\
\hline 14,36 & 563,36 & 81,0 & 1,50 & & 0,40 & & & 0,60 & 30,0 & 0,10 & 0,55 & 4,25 & 0,30 & 8,0 & 10,2 & 4150 \\
\hline 14,44 & 563,44 & 49,0 & 1,00 & & 0,25 & 0,35 & & 0,50 & 27,0 & 0,20 & 0,90 & 1,30 & 0,35 & 7,0 & 9,8 & 4600 \\
\hline 17,35 & 566,35 & 124,0 & & & 0,60 & 0,70 & & 0,40 & 80,0 & 0,05 & 1,70 & 2,05 & & 8,0 & 8,4 & 4150 \\
\hline 18,42 & 567,42 & 168,0 & & & 0,90 & 0,50 & & 0,70 & 5,00 & 0,50 & 1,40 & 1,50 & & 8,5 & 9,6 & 4150 \\
\hline 22,45 & 571,45 & 36,0 & & & 0,30 & 1,00 & & 0,40 & & 0,70 & 1,20 & 1,05 & 0,90 & 8,0 & 7,5 & 3550 \\
\hline 34,44 & 583,44 & 52,0 & & & 5,10 & 0,40 & & 0,30 & 800,0 & 2,30 & 6,90 & 9,0 & 4,0 & 5,0 & 6,5 & 1900 \\
\hline 36,40 & 585,40 & 35,0 & & & 4,75 & 0,80 & & 0,30 & 100,0 & 1,85 & 8,85 & 10,3 & 1,95 & 5,0 & 6,2 & 1800 \\
\hline 44,40 & 593,40 & 23,0 & & & 23,9 & & 0,01 & 0,35 & 200,0 & 4,75 & 25,45 & 24,1 & 7,85 & 5,0 & 6,2 & 1350 \\
\hline 61,40 & 610,40 & 15,0 & & & 119,9 & & 0,04 & 0,25 & 800,0 & 12,35 & 73,50 & 54,4 & 63,40 & 5,5 & 5,7 & 1050 \\
\hline
\end{tabular}


A.5. táblázat. Az SN 2006bp spektrumaira legjobban illeszkedő SYNOW modellek legfontosabb paraméterei.

\begin{tabular}{|c|c|c|c|c|c|c|c|c|c|c|c|c|c|c|}
\hline \multicolumn{15}{|c|}{ SN 2006bp } \\
\hline Fázis & JD-2.451.000 & & & & & & ref & & & & & $\mathrm{n}$ & $T_{\mathrm{bb}}$ & $v_{\text {modell }}$ \\
\hline (nap) & (nap) & $\mathrm{H} \mathrm{I}$ & $\mathrm{He} \mathrm{I}$ & $\mathrm{N}_{\text {II }}$ & $\mathrm{Na} \mathrm{I}$ & Si II & Ca II & Sc II & Ti II & Fe II & Ba II & & $(\mathrm{kK})$ & $\left(\mathrm{km} \mathrm{s}^{-1}\right)$ \\
\hline 5,30 & 840,30 & 2,15 & 0,15 & & & & & & & & & 4,0 & 10,2 & 12050 \\
\hline 7,10 & 842,10 & 3,20 & 0,15 & & & & & & & & & 3,5 & 12,0 & 10750 \\
\hline 9,10 & 844,10 & 6,05 & 0,15 & & & & & & & & & 4,5 & 11,7 & 9600 \\
\hline 11,11 & 846,11 & 10,35 & 0,20 & & & & & & & & & 5,5 & 12,7 & 9550 \\
\hline 15,10 & 850,10 & 15,65 & 0,05 & 0,04 & 0,20 & 0,80 & & & & 0,35 & & 4,5 & 10,8 & 8750 \\
\hline 20,28 & 855,28 & 26,70 & & 0,03 & 0,20 & 0,40 & 23,0 & 0,08 & 0,20 & 1,30 & & 4,5 & 9,5 & 8100 \\
\hline 24,26 & 859,26 & 20,00 & 0,10 & 0,01 & 0,10 & 0,10 & 25,0 & 0,10 & 0,80 & 1,50 & 0,50 & 5,5 & 8,5 & 7050 \\
\hline 32,26 & 867,26 & 59,70 & 1,50 & & 0,55 & & 129,0 & 0,30 & 1,65 & 1,75 & 0,20 & 6,0 & 8,0 & 6150 \\
\hline 41,21 & 876,21 & 118,6 & 2,00 & & 1,25 & & 326,0 & 0,65 & 3,50 & 2,60 & 0,85 & 7,0 & 7,2 & 5050 \\
\hline 56,19 & 891,19 & 145,1 & 1,00 & 4,65 & & & 300,0 & 0,20 & 6,40 & 5,35 & 0,20 & 6,0 & 7,2 & 4050 \\
\hline 72,04 & 907,14 & 150,1 & & & 18,4 & & 165,0 & 1,90 & 10,85 & 6,75 & 1,45 & 5,5 & 7,0 & 3850 \\
\hline
\end{tabular}


A.6. táblázat. Az SN 2011dh spektrumaira legjobban illeszkedő SYNOW modellek legfontosabb paraméterei.

\begin{tabular}{cccccccccccc}
\hline & \multicolumn{11}{c}{ SN 2011dh } \\
\hline $\begin{array}{c}\text { Fázis } \\
\text { (nap) }\end{array}$ & $\begin{array}{c}\text { JD-2.455.000 } \\
\text { (nap) }\end{array}$ & H I & He I & O I & $\begin{array}{c}\tau_{\text {ref }} \\
\text { Ca II }\end{array}$ & Sc II & Ti II & Fe II & & $\begin{array}{c}T_{\text {bb }} \\
(\mathrm{kK})\end{array}$ & $\begin{array}{c}v_{\text {modell }} \\
\left(\mathrm{km} \mathrm{s}^{-1}\right)\end{array}$ \\
\hline 5,3 & 718,3 & 13,8 & 0,16 & & 100 & & 1,32 & 0,54 & 5,0 & 5,26 & 11400 \\
10,3 & 723,3 & 5,75 & 0,11 & & 154 & 0,04 & 1,55 & 0,71 & 5,0 & 6,96 & 9250 \\
13,3 & 726,3 & 3,63 & 0,10 & & 47 & & 0,40 & 0,65 & 5,0 & 6,07 & 7,25 \\
16,3 & 729,3 & 3,00 & 0,10 & 0,03 & 200 & & 0,15 & 0,76 & 5,0 & 8,04 & 7200 \\
20,3 & 733,3 & 0,83 & 0,15 & & 148 & 0,01 & 0,33 & 0,18 & 6,0 & 7,09 & 7250 \\
21,3 & 734,3 & 4,67 & 0,13 & 0,03 & 0,21 & 0,03 & 0,21 & 1,15 & 6,0 & 8,21 & 7150 \\
28,7 & 741,7 & 9,33 & 0,19 & & 144 & 0,79 & 8,7 & 0,30 & 6,0 & 5,53 & 5600 \\
\hline
\end{tabular}

